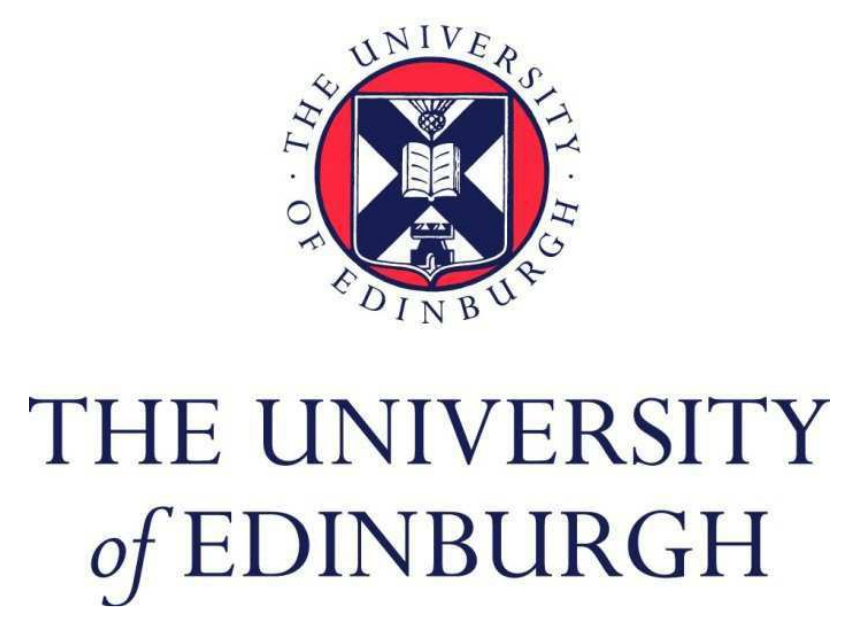

This thesis has been submitted in fulfilment of the requirements for a postgraduate degree (e.g. PhD, MPhil, DClinPsychol) at the University of Edinburgh. Please note the following terms and conditions of use:

This work is protected by copyright and other intellectual property rights, which are retained by the thesis author, unless otherwise stated.

A copy can be downloaded for personal non-commercial research or study, without prior permission or charge.

This thesis cannot be reproduced or quoted extensively from without first obtaining permission in writing from the author.

The content must not be changed in any way or sold commercially in any format or medium without the formal permission of the author.

When referring to this work, full bibliographic details including the author, title, awarding institution and date of the thesis must be given. 


\title{
Ghosts in Enlightenment Scotland
}

\author{
Martha McGill
}

Ph.D. History

The University of Edinburgh

2015 



\section{Declaration}

This thesis was composed by myself, and the work herein is my own except where explicitly stated otherwise. The thesis has not been submitted for any other degree or professional qualification.

Martha McGill 


\begin{abstract}
This thesis analyses perceptions of ghosts in Scotland, with particular focus on the period from 1685 to c. 1830 . According to traditional wisdom, this was a time when society was becoming progressively more rational, with magical beliefs melting away under the glare of Enlightenment scholarship. However, this thesis argues that ghosts actually rose to a new cultural prominence in this period, to the extent that Scotland came to be characterised as a haunted nation. The first chapter provides context, sketching attitudes towards ghosts from the Middle Ages to the late seventeenth century. It shows how ghosts were sidelined because of their questionable theological status, especially after the Reformation. The second chapter explores late seventeenth- and eighteenth-century attempts to reincorporate ghosts into Protestant society by converting them into religious propagandists. This endeavour was not only theologically problematic, but also came to be criticised on scientific grounds. Chapter three traces the evolution of sceptical and satirical depictions of ghosts, as well as discussing the debates that sprang up in the late eighteenth century as ghosts increasingly became an interesting object of enquiry. Under the pens of physicians and philosophers a medicalised vision of the ghost became widely influential. Literary works drew upon this interpretation, but also used gothic motifs to re-invest ghosts with horror. The fourth chapter discusses this theme, before exploring how romantic literature and folklore popularised a picturesque ghost that became entangled with conceptions of national identity. Finally, chapter five analyses the place of ghosts within popular culture. It uses ballads, cheap print and folklorists' accounts to assess how and why ghosts remained important to the ordinary Scottish folk. The thesis as a whole shows how the ghost's identity splintered in response to changing cultural contexts, allowing ghosts to take on new roles in Scottish society. This in turn reflects on broader questions of religious change, interactions between popular and elite culture, the formation of national identity and the legacy of the Enlightenment.
\end{abstract}




\section{Lay summary}

This thesis looks at Scottish perceptions of ghosts between about 1685 and 1830. The Scottish Enlightenment reached its peak in this period. Enlightenment thinkers argued that belief systems should be rational, so this is often seen as a time when magic stopped being relevant to everyday life. However, this thesis argues that ghosts actually became more important to Scottish culture in this period. The first chapter provides context, looking at ideas about ghosts from the Middle Ages to the late seventeenth century. It shows how kirk ministers and other educated folk dismissed ghosts because they did not fit into the accepted theological framework. The second chapter looks at attempts in the late seventeenth and eighteenth centuries to overcome this issue by turning ghosts into religious propagandists. This approach was problematic from the religious point of view, but also came to be criticised on scientific grounds. The third chapter traces the evolution of sceptical views on ghosts, and explores the debates on apparitions that developed in the late eighteenth century. Chapter four goes on to discuss ghosts in fiction, focusing in particular on the influence of gothic literature. It also examines how romantic literature and folklore turned ghosts into an important facet of Scottish national identity. Finally, chapter five uses sources such as ballads, cheap pamphlets and folklorists' accounts to analyse how and why ghosts remained important to the ordinary Scottish folk. Overall, the thesis shows that ghosts adapted to the changes of the eighteenth century, taking on new roles in Scottish society. This in turn reflects on broader questions about religion, social structures, national identity and the legacy of the Enlightenment. 


\section{Contents}

Acknowledgements

Abbreviations

viii

Introduction

1

I Historiography 2

$\begin{array}{lll}\text { II } & \text { Terminology } & 7\end{array}$

$\begin{array}{lll}\text { III Methodology } & 13\end{array}$

$\begin{array}{lll}\text { IV Structure } & 15\end{array}$

Chapter One: Scottish Ghosts: The Background 17

$\begin{array}{lll}\text { I } & \text { Medieval Ghosts } & 17\end{array}$

II The Reformation $\quad 25$

$\begin{array}{ll}\text { III } & \text { Surviving Ghost Stories }\end{array}$

IV Popular Belief and the Dead Body 37

$\begin{array}{lll}\text { V Witches and Poltergeists } & 42\end{array}$

VI Seventeenth-Century Providentialism 48

$\begin{array}{ll}\text { Conclusion } & 52\end{array}$

Chapter Two: Religious Ghosts 55

I 'That prevailing Spirit of Atheism and Infidelity' 55

$\begin{array}{ll}\text { II } & \text { Rehabilitating Ghosts }\end{array}$

$\begin{array}{ll}\text { III Second Sight and Wraiths } & 75\end{array}$ 
V Theological Controversy and the Laird of Coul's Ghost 82

VI The Decline of the Religious Ghost? 96

$\begin{array}{ll}\text { Conclusion } & 105\end{array}$

Chapter Three: Scepticism and Debate 107

$\begin{array}{lll}\text { I The Demonic Interpretation } & 107\end{array}$

II The Supernatural and the Enlightenment 109

III Mental Disorders, Dreams, Enthusiasm, and the 'Prejudices

$\begin{array}{ll}\text { of Education' } & 112\end{array}$

$\begin{array}{ll}\text { IV Ghosts and the Authorities } & 124\end{array}$

V Popular Print Culture: Debate 131

$\begin{array}{ll}\text { VI Popular Print Culture: Satire } & 135\end{array}$

VII Sceptics Meeting Ghosts: The Case of Archibald Pitcairne 141

$\begin{array}{ll}\text { Conclusion } & 143\end{array}$

Chapter Four: Ghosts in Fiction and Antiquarian Studies 145

I Developments in the Literary World 146

II 'In grim Array the grizly Spectres rise' 153

$\begin{array}{ll}\text { III Ghosts in Vernacular Poetry } & 164\end{array}$

IV Ossian and the Romanticisation of the Highlands 170

V The Ghosts of Walter Scott and James Hogg 176

$\begin{array}{ll}\text { VI Antiquarian Studies } & 180\end{array}$

$\begin{array}{ll}\text { VII Belief } & 186\end{array}$

$\begin{array}{ll}\text { Conclusion } & 191\end{array}$ 
$\begin{array}{lll}\text { I Ballads } & 196\end{array}$

II The Cheap Print Market 200

$\begin{array}{ll}\text { III Folklorists’ Accounts } & 210\end{array}$

$\begin{array}{ll}\text { IV The Highlands } & 216\end{array}$

V Fairies, Brownies, Will o’ the Wisps and Banshees 224

$\begin{array}{lll}\text { VI Belief } & 232\end{array}$

Conclusion 235

$\begin{array}{ll}\text { Conclusion } & 239\end{array}$

Appendix: The Letters of James Cowan 259

$\begin{array}{ll}\text { Bibliography } & 273\end{array}$ 


\section{Acknowledgements}

In writing this thesis I have amassed a number of debts. My two supervisors, Julian Goodare and Thomas Ahnert, have been constant sources of practical advice, constructive criticism and moral support. I am immensely grateful for their patience, kindness and expertise.

I have benefited from the suggestions and thought-provoking questions of numerous other colleagues and friends. Colin Kidd and Esther Mijers were truly inspiring examiners. I have also drawn on stimulating discussions with Adam Fox, Stana Nenadic, Alasdair Raffe and Louise Yeoman. Anna Groundwater gave me a valuable opportunity to present my research to a broader audience. Without the encouragement and guidance of Adam Budd, and the assistance of Stephen Bowd, I might never have begun this project. In addition, I am grateful to staff at the National Library of Scotland, National Records of Scotland, Edinburgh University Library, St Andrews University Library and Edinburgh City Archives.

Now and then, it is good to be distracted from the dead. On that front I must recognise the sterling work of Alice, Boris and Katherine. I am thankful to my family for the love and books, and to Matt for making me happy.

This research was funded by the Arts and Humanities Research Council. 


\section{Abbreviations}

DSL

Dictionary of the Scots Language

NLS

National Library of Scotland

NRS

National Records of Scotland

OED Online

Oxford English Dictionary Online

Oxford DNB

Oxford Dictionary of National Biography

STC

Short Title Catalogue

TNA

National Archives of the UK 


\section{Introduction}

Over the last five hundred years, the figure of the ghost has allegedly died many a death. After the Reformation (1560 in Scotland), Protestant theologians attempted to rout ghosts from their tenuous place within the Christian framework, and in 1597 James VI boasted that a Scotsman would scarcely ever hear word of 'Ghostes and spirites'. 'Sceptical approaches towards the supernatural flourished during the Enlightenment, such that ghosts were said to have been 'chased from the realities of existence ... before the light of the sun of science'. ${ }^{2}$ Nineteenth-century folklorist Walter Gregor blamed industrialisation, declaring that 'the scream of the railway whistle is scaring away ... the ghost', while literary scholars Peter Buse and Andrew Stott suggested that twentieth-century western society had replaced ghosts with aliens and conspiracy theories. ${ }^{3}$ Nevertheless, the idea of the ghost has appropriately enough - lingered on post-mortem. Owen Davies writes that ghost belief in Britain has been steadily increasing since the $1950 \mathrm{~s} .{ }^{4}$ Ghosts have retained a prominent position within popular culture, and over the last few decades they have increasingly infiltrated the world of academia. Scholars of diverse disciplines are coming to recognise the ways in which ghosts can reflect on societal development.

This thesis discusses Scottish accounts of ghosts from the late seventeenth to the early nineteenth centuries. The Enlightenment is often presented as a period of progress towards a more secular, rational society, freed from the shackles of superstition. ${ }^{5}$ However, this was also a time when ghosts attained a new cultural prominence. They regained a foothold within religious culture, and increasingly

1 James VI, 'Daemonologie, in Forme of Ane Dialogue', in James Craigie and Alexander Law (eds.), Minor Prose Works of King James VI and I (Edinburgh, 1982), bk. ii, ch. vii, 37.

2 J. Mitchell and John Dickie, The Philosophy of Witchcraft (Paisley, 1839), 355.

3 Walter Gregor, Notes on the Folk-Lore of the North-East of Scotland (London, 1881), 3; Peter Buse and Andrew Stott, 'Introduction: A Future for Haunting', in Peter Buse and Andrew Stott (eds.), Ghosts: Deconstruction, Psychoanalysis, History (Basingstoke, 1999), 1.

4 Owen Davies, The Haunted: A Social History of Ghosts (New York, 2007), 241. See also Paul Cowdell, 'Belief in Ghosts in Post-War England' (University of Hertfordshire PhD thesis, 2011), 1 .

5 Perhaps the most influential proponent of this picture of Enlightenment rationalism is Peter Gay, The Enlightenment: An Interpretation (New York, 1966). 
featured in medical discourses as psychology emerged as a discipline. The expansion of print culture facilitated the spread of ghost stories, as did the development of literature and folkloric studies. Furthermore, as depictions of ghosts evolved they fed into conceptions of local and national identity. While the Enlightenment can justifiably be lauded for its philosophical advancements, the study of ghosts offers an alternative perspective on eighteenth-century Scottish culture.

\section{Historiography}

The study of the supernatural has only recently found its place within the world of academic history. It has been hindered by the long-standing perception that supernatural beliefs cease to be relevant as societies progress into modernity. Max Weber famously argued that the Reformation inaugurated a gradual 'disenchantment of the world': religion became less dependent on ritual and sacramental magic, which laid the groundwork for subsequent secularisation and rationalisation. ${ }^{6}$ There was an important step forward for the historical study of ghosts in 1971: Keith Thomas devoted a chapter to 'Ghosts and Fairies' in his ground-breaking Religion and the Decline of Magic. Thomas allowed seventeenth-century English ghosts a significant role in upholding moral standards and social norms. However, he was working in the Weberian tradition, and presented ghosts as fading away over the eighteenth century, losing their 'social relevance'. Thereafter, Enlightenment ghosts vanished from historians' radars for another few decades. The one significant exception is R. C. Finucane's Appearances of the Dead: A Cultural History of Ghosts (1982), later revised as Ghosts: Appearances of the Dead and Cultural Transformation (1996). Finucane's work is useful as an introduction to European ghosts from antiquity onwards, but it covers too broad a geographical area and too long a timespan to delve into much detail. Finucane also follows in Thomas's footsteps, arguing that 'apparitions ... no longer played an important part in the serious debates of the

6 See Robert W. Scribner, 'The Reformation, Popular Magic, and the "Disenchantment of the World", Journal of Interdisciplinary History, xxiii (1993); Alexandra Walsham, 'The Reformation and "The Disenchantment of the World" Reassessed', Historical Journal, li (2008).

7 Keith Thomas, Religion and the Decline of Magic: Studies in Popular Beliefs in Sixteenth and Seventeenth Century England (London, 1971), 706, 724. 
articulate' during the Enlightenment. Ghosts were 'victims of eighteenth-century rationality', such that 'the apparition-world went into eclipse'. 8

Folklorists and literary scholars, meanwhile, have consistently made forays into the study of the ghost story. ${ }^{9}$ Gillian Bennett is perhaps the folklorist whose work is of most interest to the historian: her Traditions of Belief: Women and the Supernatural (1987) offers one of the earliest overviews of changing attitudes towards the ghost from the late seventeenth century. Bennett too suggested that ghosts lost their purposes from the eighteenth century as part of a process of disenchantment, but this argument is removed from the 1999 revised edition of the work, Alas Poor Ghost!: Traditions of Belief in Story \& Discourse. ${ }^{10}$ The work of literary scholars has also frequently spilled over into reflections on social history. Stephen Greenblatt's 2001 Hamlet in Purgatory focuses on the seventeenth century, analysing how the ghost of Hamlet's father expresses a multitude of fears and longings regarding death that were exacerbated by the Protestant rejection of Purgatory. ${ }^{11}$ With reference to the eighteenth century, a particularly important work is Terry Castle's 1995 The Female Thermometer: Eighteenth-Century Culture and the Invention of the Uncanny. Castle offers a more nuanced evaluation of the disenchantment theme, arguing that apparitions gradually passed from the realm of objective reality to that of internal, subjective experience. ${ }^{12}$

However, according to Buse and Stott, it is in theoretical texts that we can find the twentieth century's 'most sustained engagements' with the figure of the ghost. In particular, they highlight the importance of ghosts within psychoanalysis and deconstruction. ${ }^{13}$ Jacques Derrida's 1993 Spectres de Marx pioneered this approach.

8 R. C. Finucane, Ghosts: Appearances of the Dead and Cultural Transformation (Amherst [N.Y.], 1996), 165-9 (quotations 165 and 169).

9 See Hilda Roderick Ellis Davidson and W. M. S. Russell (eds.), The Folklore of Ghosts (Cambridge, 1981), and the discussion in Peter Marshall, Beliefs and the Dead in Reformation England (Oxford, 2002), ch. 6.

10 Gillian Bennett, Traditions of Belief: Women and the Supernatural (London, 1987), 175-88. An earlier, but less notable folkloric work is Eric Maple, The Realm of Ghosts (London, 1964).

11 Stephen Greenblatt, Hamlet in Purgatory (Princeton, 2001), 235-57.

12 Terry Castle, The Female Thermometer: Eighteenth-Century Culture and the Invention of the Uncanny (Oxford, 1995), ch. 10.

13 Buse and Stott, 'Introduction', 5. 
It is Derrida we must thank, argues Colin Davis, for the 'rehabilitation of ghosts as a respectable subject of enquiry'. ${ }^{14}$ Derrida's spectres are 'standard-bearers of deconstructionism', breaking down barriers between past and present, life and death, body and spirit. ${ }^{15}$ His notion of 'hauntology' holds that the present exists only in relation to the past, and history is formed through the 'spectral iteration' of texts or ideas, such that modern society is fashioned by the ghosts of the past. Derrida employs the ghost as a metaphorical figure, but his analysis is nonetheless significant for those studying actual ghost-sightings. The sociologist Avery F. Gordon builds upon Derrida's work to interpret modern-day ghost-sightings as the haunting of the present by dark, repressed aspects of the past, such as slavery. Historian Shane McCorristine speaks of Derrida as forming part of the essential theoretical framework behind his study of late-eighteenth and nineteenth-century ghost belief: his notion of the ghost as being expressive of 'the haunted nature of modern subjectivity' is decidedly in the Derridean tradition. ${ }^{16}$

While folklorists, literary scholars and philosophers dominated ghost studies in the late twentieth century, the twenty-first century has seen a surge in historical studies. In part this is because the Weberian picture of disenchantment has lost ground. Particularly notable critiques include those of Robert Scribner, who argues that magic changed rather than disappearing in the wake of the Reformation, and Alexandra Walsham, who suggests that it is more useful to think in terms of cycles of 'desacralization' and 'resacralization'. ${ }^{17}$ Supernatural topics broadly have increasingly attracted scholarly attention. ${ }^{18}$ With this backdrop, studies on ghosts in

14 Colin Davis, 'État Présent: Hauntology, Spectres and Phantoms', French Studies, lix (2005), 373.

15 Owen Davies, 'Introduction', in Owen Davies (ed.), Ghosts: A Social History, 5 vols. (London, 2010), i, xv; Buse and Stott, 'Introduction', 10.

16 Avery F. Gordon, Ghostly Matters: Haunting and the Sociological Imagination (Minneapolis, 2008); Shane McCorristine, Spectres of the Self: Thinking About Ghosts and Ghost-Seeing in England, 1750-1920 (Cambridge, 2010), 4, 32.

17 Scribner, 'Reformation'; Walsham, 'Reformation and "The Disenchantment of the World"'. See the conclusion for further discussion of these themes.

18 Setting aside works focusing on Scotland, which are outlined below, a few examples include Alexandra Walsham, Providence in Early Modern England (Oxford, 1999); William E. Burns, An Age of Wonders: Prodigies, Politics, and Providence in England, 1657-1727 (Manchester, 2002); Diane Purkiss, Troublesome Things: A History of Fairies and Fairy Stories (London, 2000); Euan Cameron, Enchanted Europe: Superstition, Reason, and Religion, 1250-1750 (Oxford, 2010); Stuart Clark, Thinking with Demons: The Idea of Witchcraft in Early Modern Europe (Oxford, 1997). 
English culture have flourished. Peter Marshall, Amanda Jane McKeever and John Newton have discussed how apparitions reflect on attitudes towards death and the afterlife in the sixteenth and seventeenth centuries. ${ }^{19}$ Sasha Handley, Jo Bath, John Newton and Frederick Valletta have explored the late seventeenth-century rehabilitation of the ghost by Protestant authorities. ${ }^{20}$ Ghost stories of the long eighteenth century are insightfully analysed by Handley, and the aforementioned work of Shane McCorristine traces the evolution of ghosts in the late eighteenth century and beyond. More broadly, Owen Davies has discussed the social history of ghosts over a long time-span, and P. G. Maxwell-Stuart has looked at patterns across Europe from the ancient world to the twentieth century. ${ }^{21}$ Many of these works take an interdisciplinary approach. Handley draws upon sociolinguistic theories to analyse narrative patterns within ghost stories; Owen Davies delves into the world of folklore; Shane McCorristine's study is quasi-psychological, building on the work of Terry Castle and (as we have seen) Derrida. Nevertheless, they are first and foremost historical studies, and have demonstrated how ghosts can reflect on social and cultural history despite (or because of) the impact of the Reformation and the Enlightenment.

With the exception of Maxwell-Stuart's pan-European survey, however, all of these works have focused on England. There have yet to be any academic works on Scottish ghost belief. Other supernatural phenomena have fared better. Witcheraft in Scotland has attracted a number of excellent studies, and trial records have been

19 Marshall, Beliefs and the Dead; Peter Marshall, 'Deceptive Appearances: Ghosts and Reformers in Elizabethan and Jacobean England', in Helen Parish and William G. Naphy (eds.), Religion and Superstition in Reformation Europe (Manchester, 2002); Amanda Jane McKeever, 'The Ghost in Early Modern Protestant Culture: Shifting Perceptions of the Afterlife, 1450-1700' (University of Sussex DPhil thesis, 2010); John Geoffrey Newton, 'An Examination of Interpretations of Ghosts from the Reformation to the Close of the Seventeenth Century' (Durham University $\mathrm{PhD}$ thesis, 2003).

20 Sasha Handley, 'Reclaiming Ghosts in 1690s England', in Kate Cooper and Jeremy Gregory (eds.), Signs, Wonders, Miracles: Representations of Divine Power in the Life of the Church (Woodbridge, 2005); Jo Bath and John Newton, "'Sensible Proof of Spirits": Ghost Belief during the Later Seventeenth Century', Folklore, cxvii (2006); Frederick Valletta, Witchcraft, Magic and Superstition in England, 1640-1670 (Aldershot, 2004), ch. 3.

21 Sasha Handley, Visions of an Unseen World: Ghost Beliefs and Ghost Stories in EighteenthCentury England (London, 2007); McCorristine, Spectres of the Self; Davies, Haunted; P. G. Maxwell-Stuart, Ghosts: A History of Phantoms, Ghouls \& Other Spirits of the Dead (Stroud, 2006). 
catalogued in the online database The Survey of Scottish Witchcraft (2003). Fairies and second sight have not been explored quite as extensively as witchcraft, but have nevertheless received some scholarly attention. ${ }^{22}$ However, none of these works have given more than a brief nod to ghosts. Studies of witchcraft, moreover, tend to focus primarily on the sixteenth and seventeenth centuries; the ways in which supernatural belief evolved as the Enlightenment progressed remain under-researched. There is a useful introductory analysis in Colin Kidd's 'The Scottish Enlightenment and the Supernatural', which appears in Lizanne Henderson's 2009 Fantastical Imaginations (itself a valuable resource on a range of supernatural topics). Kidd primarily discusses miracles, however, and does not delve into the realm of folklore. Perhaps the most extensive analysis on supernaturalism during the Scottish Enlightenment can be found in Paul Kléber Monod's Solomon's Secret Arts: The Occult in the Age of Enlightenment (2013). Monod concentrates primarily on practices such as alchemy, astrology and ritual magic, defining 'occult' as 'a type of thinking, expressed either in writing or in action, that allowed the boundary between the natural and the supernatural to be crossed by the actions of human beings' ${ }^{23}$ The Scottish Enlightenment, he argues, succeeded in stamping out the occult, backed by 'a century of determined Presbyterian denunciation of anything occult as diabolical'. This is in contrast to England, where the second half of the eighteenth century saw a 'remarkable revival' of occult thinking. ${ }^{24}$ Like Kidd, Monod focuses on elite culture and is less concerned with folklore, but his work reinforces the importance of considering the English and Scottish cases separately. The study of ghosts thus addresses a lacuna in our current understanding of the Scottish supernatural, and is all the more valuable given the divergent paths of English and Scottish intellectual and religious culture over the course of the eighteenth century.

22 Julian Goodare et al., The Survey of Scottish Witchcraft (University of Edinburgh, 2003), http://www.shca.ed.ac.uk/witches, accessed 1 Aug. 2015; Brian P. Levack, Witch-Hunting in Scotland: Law, Politics and Religion (London, 2008); Julian Goodare (ed.), The Scottish WitchHunt in Context (Manchester, 2002); Julian Goodare, Lauren Martin, and Joyce Miller (eds.), Witchcraft and Belief in Early Modern Scotland (Basingstoke, 2008); Lizanne Henderson and Edward J. Cowan, Scottish Fairy Belief: A History (East Linton, 2001); Emma Wilby, Cunning Folk and Familiar Spirits: Shamanistic Visionary Traditions in Early Modern British Witchcraft and Magic (Brighton, 2005); Michael Hunter (ed.), The Occult Laboratory: Magic, Science, and Second Sight in Late Seventeenth-Century Scotland (Woodbridge, 2001).

23 Paul Kléber Monod, Solomon's Secret Arts: The Occult in the Age of Enlightenment (New Haven, 2013), 5.

24 Monod, Solomon's Secret Arts, 227, 340-6. 


\section{Terminology}

From the medieval period to the early nineteenth century, a variety of terms were used to refer to ghosts. Probably the most common was the generic 'spirit' (or variations such as 'spreit' or 'spreyt'), which could also apply to angels and demons. 'Apparition' was another relatively vague term that appeared with reasonable frequency. The word 'ghost' was used too, along with its Scots equivalent 'ghaist' and variations including 'gost' and 'ghest'. It was understood more broadly than it is today, however: it could refer to the returning dead, but also to a soul or spirit. 'Giving up the ghost' was a common euphemism for dying, and the Holy Ghost was understood to be a spirit. In 1616 a character of William Drummond's lamented that he was left to wail in the fashion of 'some Heaven-banish'd Ghost': here the term perhaps signifies a demon. ${ }^{25}$ In 1707, the minister Robert Wodrow recorded a story of a 'gost' that closely resembled a demon: it took the form of 'ane litle old man about the height of the table, with a fearful ougly face, as if it had been all brunt'. It declared that it had come from Hell, and attacked a set of bibles. ${ }^{26}$ The 'demon' interpretation does not seem to have been widely recognised, however. In a work published posthumously in 1692, the minister Thomas Bell wrote: 'a Spirit clashing with the Word, is surely a Ghost and an evil Spirit'. The 1705 edition saw fit to revise this to 'a false and an evil spirit'. ${ }^{27}$

It was also possible to use the term to refer to a monstrous living being. The ballad 'King Henry'(Child 32) presents a 'grisly ghost' - a living woman under a spell, who appears as a huge, hideous creature with teeth like tethering stakes. ${ }^{28}$ The poets William Dunbar and Alexander Montgomerie also used the term in this manner. Montgomerie wrote in c. 1580 of how his flyting opponent, Patrick Hume of

25 William Drummond, Poems: By William Drummond, of Hawthorne-Denne (Edinburgh, 1616, STC 7255), pt. i.

26 Robert Wodrow, Analecta: Or Materials for a History of Remarkable Providences Mostly Relating to Scotch Ministers and Christians, ed. Matthew Leishman, 4 vols. (1842-3), i, 112-14.

27 Thomas Bell, Nehemiah the Tirshatha, Or, The Character of a Good Commissioner to Which Is Added Grapes in the Wilderness (Edinburgh, 1692), 25; Thomas Bell, Grapes in the Wilderness: Or, A Discourse of the Dispensations of God towards His People (Glasgow, 1705), xxi.

28 Francis James Child, The English and Scottish Popular Ballads, 5 vols. (Boston, 1882-98), i pt. ii, 298-9. 
Polwart, had been born to an ape and abandoned under a bush, swaddled in pig's skin and smeared with soot. The 'Weird Sisters', coming across him, wondered how the 'gaist had been gotten'. In an equally colourful passage from the late fifteenth or early sixteenth century, Dunbar has an unhappy wife complain of her husband:

Bot quhen that glourand gaist grippis me about, Than think I hiddowus Mahoune hes me in armes, ${ }^{29}$

Over the seventeenth and eighteenth centuries the anglicised 'ghost' gradually became more common, however, and in the eighteenth and early nineteenth centuries the 'returning dead person' definition seems to have become dominant.

'Bogle' is another noteworthy Scots word. It could signify a ghost, but tended to denote a mischievous spirit of uncertain origin. The term cropped up fairly frequently in the sixteenth century, and survived into the nineteenth. An 1817 article described a bogle who was 'neither fairy, ghost, nor brownie, but appears to have partaken somewhat of the peculiar attributes of all the three', while James Hogg explained:

A fairy is a spirit sweet,

The Brownie kind an' just, too;

A ghaist, row'd in its windin' sheet, I own, is nought to trust to:

But o' the awsome things complete

To ruin youthfu' sporting,

A bogle is the warst to meet,

When fo'ks gang to the courting. ${ }^{30}$

Rarer terms for ghosts included the English 'bugbear'; variants of 'shadow'; and Latin terms. William Birnie wrote in 1616 of 'Larvæ or Lemures, that is, bogils or

29 Alexander Montgomerie and Patrick Hume, 'The Flyting Betwixt Montgomery and Polwart', in James Cranstoun (ed.), The Poems of Alexander Montgomerie (Edinburgh, 1887), 1. 291, p. 69; William Dunbar, 'Apon the Midsummer Evin, Mirriest of Nichtis (The Tretis Of The Twa Mariit Wemen and the Wedo)', in Jacqueline Tasioulas (ed.), The Makars: The Poems of Henryson, Dunbar and Douglas (Edinburgh, 1999), 11. 100-1, p. 550. 'Mahoune' signified the Devil. On the passage from Montgomerie see Jacqueline Simpson, "“The Weird Sisters Wandering": Burlesque Witchery in Montgomerie's Flyting', Folklore, cvi (1995).

30 James Hogg, 'The Bogle', Edinburgh Literary Journal, Mar. 1831, 171-2; E., 'Border Sketches No. II', Edinburgh Magazine and Literary Miscellany, Oct. 1817, 238. 
gaistes', and James VI used 'umbræ mortuorum' to refer to ghosts (the literal translation is 'shades of the dead'). ${ }^{31}$ An English/Latin vocabulary published in Edinburgh in 1720 included a section on 'created beings', which translated ghosts as 'Umbrae', fairies as 'Lemures,' and a vision or phantom as 'Spectrum'. ${ }^{32}$ The Latin 'spectrum' and 'phantasma' also spawned the terms 'spectre' and 'phantom'. The former was perhaps in use from the sixteenth century (James VI employs it in his 1597 Daemonologie) and the latter from the fourteenth. ${ }^{33}$ However, they became significantly more popular in the late eighteenth and early nineteenth centuries. Their relative rarity at the beginning of this timespan can be seen in an extract from a 1787 poem by James Fordyce:

At length a voice the solemn silence broke, And thus, in hollow tone, the phantom* spoke;

A helpful note clarified that 'phantom' meant an 'apparation'. ${ }^{34}$ By the nineteenth century, however, 'phantoms' were a common feature of romantic writing. The terminology for ghosts thus evolved in response to changing cultural contexts. The difficulty of determining the precise nature of a reported apparition can be a challenge for the historian, but as we shall see, it was no less a problem for contemporaries.

For the sake of clarity, this thesis will generally use the term 'ghost' to refer to a dead person reappearing among the living, even if it was not the term employed by the contemporary describing the event. I will, however, assign different labels to certain sub-categories of ghost. 'Wraith' (or similar terms such as wrath, wrathys, wrethis, wrayth, wratch) was a Scots word that appeared in Gavin Douglas's 1513 translation of The Aeneid. Douglas seems to equate wraiths with ghosts:

in diverse places

The wraiths walks of ghaists that are deid, ${ }^{35}$

31 James VI, 'Daemonologie', bk. iii, ch. i, 39.

32 A New Vocabulary English and Latin, for the Use of Schools, 5th edn (Edinburgh, 1720), 2.

33 James VI, 'Daemonologie', preface, xix.

34 James Fordyce, 'The Vision', A Collection of Hymns and Sacred Poems (Aberdeen, 1787), 140.

35 Gavin Douglas, The Aeneid (1513), ed. Gordon Kendal (London, 2011), bk. x, 1. 93, p. 517. 
For James VI, however, the term had a more precise meaning. He explained that a wraith was the spectral appearance of a person either soon before their death, or when 'newlie dead'. ${ }^{36}$ I will employ James's definition, as there is a relatively large body of stories on apparitions appearing for a few brief moments at the precise time of death, and it is useful to have a label for them. ${ }^{37}$ 'Revenant' and 'poltergeist' are also helpful terms, although anachronistic (both appeared in English in the nineteenth century). ${ }^{38}$ Revenants were a subset of ghosts, particularly popular during the medieval period, who returned as walking corpses. They were especially common in the Icelandic sagas, where they were known as 'draugr', but they were well attested in England, the Low Countries, northern France and parts of Germany. ${ }^{39}$ As we shall see, there were also a few Scottish cases. Revenants had generally lost all vestiges of humanity, and behaved in a violent and cruel manner. Poltergeists - spirits who haunted houses - likewise tended to be malevolent in nature. The direct translation, 'noisy ghosts', reflects the fact that they were generally seen, rather than heard. They did occasionally take visible forms, however. Animal forms were seen quite frequently, and several poltergeists appeared as naked arms, perhaps in reference to their habits of knocking and throwing things ${ }^{40}$ As we shall see, poltergeists could be interpreted as returning dead people, but were more usually classed as demons.

My use of the term 'supernatural' is also anachronistic. In the period from the Middle Ages to the early nineteenth century this term had a more precise meaning. As explained by Thomas Aquinas, supernatural events were the unmediated actions of God, and could not be explained by any natural laws. Preternatural events were outof-the-ordinary occurrences that happened by the agency of created beings, or by the

36 James VI, 'Daemonologie', bk. iii, ch. i, 42.

37 See the discussion on pp. 77-9.

38 'Revenant, n. and adj.2', OED Online (University of Oxford, June 2015), http://www.oed.com/view/Entry/164711?rskey=2eZbwA\&result=1\&isAdvanced=false, accessed 1 Aug. 2015; 'poltergeist, n.', OED Online (University of Oxford, June 2015), http://www.oed.com/view/Entry/147029?redirectedFrom=poltergeist, accessed 1 Aug. 2015.

39 N. K. Chadwick, 'Norse Ghosts (A Study in the Draugr and the Haugbúi)', Folklore, lvii (1946), 50-65; Ármann Jakobsson, 'The Fearless Vampire Killers: A Note about the Icelandic Draugr and Demonic Contamination in Grettis Saga', Folklore, cxx (2009), 307-16; Nancy Caciola, 'Wraiths, Revenants, and Ritual in Medieval Culture', Past \& Present, clii (1996), 15.

40 Sinclair, Satan's Invisible World Discovered, 159; Wodrow, Analecta, ii, 95. 
agency of nature, as directed by God. God himself was supernatural, whereas other spiritual beings (with the possible exception of angels) were usually consigned to the realms of the preternatural. For theologians, therefore, ghosts were not supernatural beings. ${ }^{41}$ In practice, however, the terms 'preternatural' and 'supernatural' did not generally appear in Scottish discussions of ghosts. It could certainly be argued that these labels were debated implicitly, if not explicitly. To interpret a ghost as a message from God, a diabolic trick, or the product of a diseased mind was to define its place on the scale of natural, preternatural and supernatural. Nonetheless, to insist too much on the distinctions between these categories is to assign them an importance that is not justified by their limited use in the source material. I therefore generally use the term 'supernatural' in its modern sense, as a convenient shorthand for a range of phenomena (ghosts included) that did not have a place within the usual natural order.

Another point that requires justification is my use of the designations of 'popular' and 'elite' culture. Ever since E. P. Thomson's 1966 essay on 'History from Below', there have been ongoing attempts to find the boundaries between those 'above' and those 'below', and the distinctions between 'popular' and 'elite' remain debated among theorists today. ${ }^{42}$ This work is not concerned with the knotty question of how, exactly, these terms should be defined. I do work to the premise that there was a 'popular culture' in Enlightenment Scotland. This should not be taken as a given; Holt N. Parker explains that 'nearly all theories of popular culture take it as given that popular culture is a phenomenon dating from, or indeed caused by, the Industrial Revolution'. ${ }^{43}$ In Scotland the industrial revolution is most commonly dated from

41 Clark, Thinking with Demons, 152-5; Walsham, Providence, 230; Lorraine Daston and Katharine Park, Wonders and the Order of Nature, 1150-1750 (New York, 1998), 121-6; Lorraine Daston, 'Marvelous Facts and Miraculous Evidence in Early Modern Europe', Critical Inquiry, xviii (1991), 95-100.

42 E. P. Thompson, 'History from Below', The Times Literary Supplement, mmmcccxlv (1996), 279. The literature on this topic is extensive, but for a few examples of the continuing debate see Bob Scribner, 'Is a History of Popular Culture Possible?', History of European Ideas, x (1989), 17591; Gerald Strauss, 'The Dilemma of Popular History', Past \& Present, cxxxii (1991), 130-49; William Beik, 'The Dilemma of Popular History', Past \& Present, cxli (1993), 207-15; Gerald Strauss, 'The Dilemma of Popular History: Reply', Past \& Present, cxli (1993), 215-19; Holt N. Parker, 'Toward a Definition of Popular Culture', History \& Theory, 1 (2011), 147-70.

43 Parker, 'Toward a Definition of Popular Culture', 148. 
about the $1780 \mathrm{~s} .{ }^{44}$ Furthermore, many historians reject the terms 'popular' and 'elite' outright, noting that these categories imply a clean social divide that did not and could not exist in practice.

However, there was a meaningful distinction between popular and elite in preindustrial Scottish society, despite the fact that the boundaries were not clear-cut. R. A. Houston suggests that in the mid-eighteenth century about $5 \%$ of Lowland males were lairds and professional men, 20\% were craftsmen and tradesmen, $25 \%$ tenant farmers, and 50\% labourers, cottars or servants. Literacy itself was not the norm. Houston estimates an illiteracy level of about 35\% for men and $70 \%$ for women in the Lowlands. In the Highlands the rates stood at about $55-60 \%$ for men, or $90 \%$ for women. ${ }^{45}$ Alexander Webster's pioneering 1755 census placed over half of Scots north of the Tay. In $175017.3 \%$ of Scots lived in towns with more than 2,500 inhabitants, and while this was high by European averages, it further underlines that the cluster of educated men living and writing in Edinburgh or other large burghs were anomalous in Scottish society as a whole. ${ }^{46}$ The vast majority of surviving records of ghosts were made by men who fall into the class of lairds and professionals, as well as being literate and (most usually) based in urban centres. The available evidence is, therefore, skewed. It is important to bear in mind that there was a divide between these educated, socially privileged individuals and the broad swathes of Scottish folk who did not have the leisure hours, financial freedom or education to directly participate in print culture. 'Elite' and 'popular' are convenient labels for this purpose, despite lacking precise definitions.

44 Christopher A. Whatley, The Industrial Revolution in Scotland (Cambridge, 1997), 7.

45 R. A. Houston, Scottish Literacy and the Scottish Identity: Illiteracy and Society in Scotland and Northern England, 1600-1800 (Cambridge, 2002), 56; R. A. Houston, 'Women in the Economy and Society of Scotland, 1500-1800', in R. A. Houston and I. D. Whyte (eds.), Scottish Society, 1500-1800 (Cambridge, 1989), 136.

46 R. E. Tyson, 'Population Patterns to 1770', in Michael Lynch (ed.), Oxford Companion to Scottish History, electronic edn (University of Oxford, 2007), http://www.oxfordreference. $\mathrm{com} /$ view/10.1093/acref/9780199234820.001.0001/acref-9780199234820-e-238?rskey=5tA1US \&result=1\#acref-9780199234820-eSub-0180, accessed 1 Aug. 2015. 


\section{Methodology}

The sources on early modern Scottish ghosts are limited. Besides a few interesting needles that can be found in the haystacks of kirk and court session records, the main sources are those few ghost stories that were published in treatises and pamphlets, discussed in letters, or recorded in manuscript form. Matters improve from the second half of the eighteenth century. As the print market expanded, ghosts increasingly appeared in periodicals, broadsides, chapbooks, plays and collections of poetry. In the nineteenth century they worked their way into short stories and novels. This period also saw the rapid development of antiquarian studies, resulting in a huge increase in useful material. Many nineteenth-century folklorists claimed to be recording stories from centuries previously, but my approach in this thesis is to use only material that can be demonstrably traced back to the period in question. Thus, in the absence of supplementary evidence, I use the records of early nineteenth-century folklorists to reflect on nineteenth-century patterns, not to draw conclusions about earlier parts of the period.

This thesis makes use of both fictional and non-fictional accounts of ghosts. There are three reasons for this. Firstly, fictional works played an important role in creating and popularising new visions of the ghost. Secondly, the ways in which people thought about fictional ghosts could influence their readings of non-fictional accounts. Thirdly, it is often difficult to disentangle fictional ghosts from their nonfictional counterparts; many accounts straddled both categories. This is not to imply that it is pointless to ask whether a given ghost story was read as a piece of entertainment or a factual account. The question of belief is an important one, and I shall return to it throughout the thesis. It is, however, a very difficult question to address. It is generally impossible to know how a ghost story was received, and how widely it was credited. The only information available about levels of popular belief is the anecdotal accounts of folklorists, which by no means offer a consistent picture. It is also possible to get blinkered by the question of belief, and overlook the ways in which ghosts could be important even when not presented or received as objective realities. Ghosts did not have to be actually patrolling the ramparts of Scottish castles 
to have a significant cultural presence.

While the question of belief naturally coloured contemporaries' views of ghosts, it is no less an issue for historians working on this topic. Lyndal Roper, writing about reports of witchcraft, points out that 'as a profession used to addressing documents for their reliability, it is hard to know how to interpret documents which we do not believe to be factual'. ${ }^{47}$ Roper addresses the problem through a psychoanalytical approach, aiming to get inside the head of those who produced the documents in question. It would be harder to adopt this approach in the case of ghosts, because very few first-hand accounts of ghost sightings survive. Most stories describe ghosts seen by relatives, acquaintances, or communities. This renders it difficult to make generalisations about those people who actually saw ghosts (or thought they did). The issue is complicated by the fact that the non-existence of ghosts is probably not as generally accepted nowadays as the non-existence of witches. The historical belief in witches had terrible consequences; ghosts do not carry the same emotional baggage. The edited collection Early Modern Ghosts (2002) contains not only a selection of academic essays on the historical value of ghosts, but also an essay by Ian S. Baker on contemporary parapyschological research. Baker concludes that it is very difficult to say whether ghosts do or do not exist. ${ }^{48} \mathrm{I}$ do not believe in ghosts myself, which inevitably influences my reading of the sources to an extent - but historians must always be bound by their personal perspectives. Furthermore, the lack of first-hand accounts has its advantages: rather than delving into the thorny question of why people saw ghosts, it becomes natural to ask instead why people chose to circulate ghost stories. Again, whether or not ghosts were really making appearances, the ways in which they were used can offer valuable insights into contemporary concerns.

47 Lyndal Roper, 'Witchcraft and Fantasy in Early Modern Germany', History Workshop, xxxii (1991), 21-2.

48 Ian S. Baker, “'Do Ghosts Exist?”: A Summary of Parapsychological Research into Apparitional Experiences', in John Newton and Jo Bath (eds.), Early Modern Ghosts (Durham, 2002), 120. 


\section{Structure}

This thesis focuses primarily on the period from 1685 (when George Sinclair published Satan's Invisible World Discovered) to the early nineteenth century. The first chapter contextualises this material, giving a basic overview of Scottish ghosts from the medieval period up to the late seventeenth century. Thereafter the thesis is arranged thematically, although there is a chronological slant to the focus of the chapters. The second chapter discusses ghosts in religious culture. It is mainly grounded in the late seventeenth and early eighteenth centuries, as this period saw a tentative drive to rehabilitate ghosts as Protestant propagandists. Ghosts were used sporadically throughout the eighteenth century to make religious arguments, however, and the chapter goes on to discuss the ways in which they reflected on specific theological debates. The third chapter looks at how perceptions of ghosts changed amid the philosophical and scientific advances of the Enlightenment, particularly in the latter half of the eighteenth century. Sceptical stances on ghosts evolved. Most notably, as psychology developed as a discipline, ghosts were increasingly portrayed as the products of a disordered mind. The emergence of a periodical culture also opened up a new venue for debate, and the nature of ghosts was scrutinised in articles in the Edinburgh Weekly Magazine.

The fourth chapter considers ghosts as portrayed by fiction-writers and folklorists, drawing most of its material from the late eighteenth and early nineteenth centuries. The emergence of gothic literature saw the horrifying aspects of the ghost exploited in new ways, offering reflections on death and insanity that were in stark contrast to the visions of the kirk and Enlightenment physicians. Meanwhile, both literary works and antiquarian studies increasingly yielded to a romantic agenda, portraying ghosts as facets of a picturesque national identity. As these chapters are mainly concerned with the ways in which ghosts were used, discussed and explored in educated culture, the last chapter focuses on popular culture. Taking the period as a whole, it looks at sources such as ballads, pamphlets and folklorists' accounts to investigate perceptions of ghosts among that great majority of the population who did not leave written records. It discusses what popular Scottish ghosts were actually like, and how 
they reveal contemporary preoccupations. Thereafter, the conclusion returns to a few overarching themes. What functions did ghosts serve in Scottish society, and how did perceptions of them develop over the Enlightenment period? These questions act as pathways into broader historiographical debates about the fate of magic in the eighteenth century, relations between popular and elite culture and the formation of Scottish nationhood. 


\section{Chapter One}

\section{Scottish Ghosts: The Background}

There are few records of Scottish ghosts before the eighteenth century. Charting their history entails a good deal of conjecture. The Europe-wide picture is better documented, however, and offers some contextualisation for the sparse Scottish sources. This chapter will begin by discussing the place of ghosts in medieval society, first in Europe as a whole and then in Scotland specifically. It is useful to make a speculative sketch of some of the typical features of medieval ghosts, to serve as a point of comparison when it comes to considering how ghosts developed later on. The Reformation is usually presented as a particularly important turning point. This chapter will examine the effect of Protestantism on both elite and popular views of ghosts in Scotland, as well as considering the impact of the witch hunts. Finally, the chapter will discuss how changes in seventeenth-century religious culture coloured the ways in which apparitions were presented. Overall, the aim of the chapter is to assess how ghosts stood in Scottish society prior to the developments of the long eighteenth century.

\section{Medieval Ghosts}

In early medieval Europe, most clerical figures rejected the idea that dead souls could return to earth. Ghost stories had been common in the classical world, and carried flavours of paganism in the eyes of the early church fathers. The main biblical justification for ghosts was the Old Testament story of the Witch of Endor raising Samuel. However, the 'ghost' of Samuel was tainted by association with witchcraft and necromancy, and the apparition was usually taken to be a diabolic trick. Tertullian (c.160-c.230) and Lactantius (c.250-c.325) dismissed ghosts as a vulgar superstition. Augustine of Hippo (354-430) allowed only for the 'image' of a dead person to return, as opposed to an actual spirit or soul, and explained that this 
image was created by angels or demons. ${ }^{1}$ Jean-Claude Schmitt argues that ghost stories remained rare until the ninth century, when Augustine's teachings on the subject were finally forgotten amidst developments in the liturgy for the dead. Records of popular ghost stories multiplied over the eleventh and twelfth centuries, and in the wake of the 'birth of Purgatory' in the late twelfth century, some clerical figures began actively to promote ghost stories as proof of a middle ground for souls. $^{2}$ They were tentatively endorsed by Thomas Aquinas (1225-74), who suggested that 'according to the disposition of Divine Providence separated souls sometimes come forth from their abode and appear to men'. ${ }^{3}$

In general, the ghosts of medieval Europe looked much as they had when alive. Their dress was usually unchanged: a knight would sport armour and weapons, while a monk would be clad in his robe. Sometimes the colours of the ghosts' garments took on particular significance. Many ghosts would initially appear in black. For their next appearance they would come dressed in half black, next in half white, and finally all in white: this change represented the progression through Purgatory. ${ }^{4}$ Red was also a popular colour for ghosts. The archetypal all-white ghost was less common, although Claude Lecouteux has suggested that there was a tradition of 'white ladies' who appeared to foreshadow deaths. ${ }^{5}$ Schmitt writes: 'Before the end of the Middle Ages, ghosts were hardly ever described as being more or less naked cadavers or as wearing only their shrouds'. ${ }^{6}$ Medieval artwork occasionally depicted ghosts as immaterial phantoms, invisible beings, or souls in animal forms, but more usually they were corporeal, and retained close ties to their dead bodies. If a ghost had died from wounds, they would often still be fresh and bleeding when it returned. ${ }^{7}$ The extreme example of the corporeal ghost was the revenant, or 'living corpse'. Revenants rose soon after death, before the body was decayed. They frequently

1 Jean-Claude Schmitt, Ghosts in the Middle Ages: The Living and the Dead in Medieval Society, trans. Teresa Lavender Fagan (Chicago, 1998), 17-22.

2 Ibid., 4-5; Jacques Le Goff, The Birth of Purgatory, trans. Arthur Goldhammer (Chicago, 1986).

3 Thomas Aquinas, Summa Theologica, trans. Fathers of the English Dominican Province (New York, 1947), 'Treatise on the Resurrection', Q. LXIX. See also 'Treatise on Man', Q. LXXXIX.

4 Schmitt, Ghosts in the Middle Ages, 204.

5 Claude Lecouteux, Return of the Dead: Ghosts, Ancestors, and the Transparent Veil of the Pagan Mind, trans. John E. Graham (Rochester [Vt.], 2009), 119-20.

6 Schmitt, Ghosts in the Middle Ages, 195-205, 202.

7 Ibid., 196-8, 206. 
attacked the living, and were interpreted as demons by some writers. ${ }^{8}$

The dead almost always appeared at night time. Some ghosts liked wild outside spaces, or abandoned houses, but most returned to the houses they had inhabited when alive, or to cemeteries. ${ }^{9}$ They appeared most often to their past friends or relatives. With the exception of the bloodthirsty revenants, most ghosts had some positive moral or religious function. They often returned to confess to sins committed during their lifetimes, and atone for them where possible. Some came back to request that more prayers should be said for them, or that some irregularity in their burial should be corrected. Certain people were condemned to wander as ghosts because they had died a violent or untimely death, or died in an unfinished state - unbaptised, in childbirth, or with some important business left unresolved. Others were unable to rest because their sins during life made for an agonisingly long spell in Purgatory. ${ }^{10}$ Most of these Europe-wide patterns seem to have been known in Scotland. The ghost of Gy de Thurno (or de Corvo) demonstrates how stories could travel across borders. After conducting an illicit sexual act with his wife, Gy could not escape Purgatory; he haunted his house until the local friars said enough prayers to speed his passage to Heaven. The story, originally from France, was published in a mid fourteenth-century Latin tract entitled Spiritus Guidonis, which was translated into Middle English as The Gast of Gy. In Scotland, William Dunbar (b. c. 1460) insulted Walter Kennedy by calling him 'thow spreit of Gy', and David Lindsay (c. 1486-1555) noted that he would dress up for the young James V's amusement 'sumtyme lyke the greislie gaist of Gye'. ${ }^{11}$

8 See Nancy Caciola, 'Wraiths, Revenants, and Ritual in Medieval Culture', Past \& Present, clii (1996), 10-15. See also Jacqueline Simpson, 'Repentant Soul or Walking Corpse? Debatable Apparitions in Medieval England', Folklore, cxiv (2003), 389-402; Andrew Joynes (ed.), Medieval Ghost Stories: An Anthology of Miracles, Marvels, and Prodigies (Woodbridge, 2001), pt. 3.

9 Schmitt, Ghosts in the Middle Ages, 172-94.

10 Alexander Murray, Suicide in the Middle Ages, Vol. 2: The Curse on Self-Murder (Oxford, 2000), 471-81; Schmitt, Ghosts in the Middle Ages, 2-3, 185-94. There are also some useful comments in R. A. Bowyer, 'The Role of the Ghost-Story in Mediaeval Christianity', in Helen Parish (ed.), Superstition and Magic in Early Modern Europe: A Reader (London, 2015).

11 William Dunbar, 'Schir Johine the Ros, Ane Thing Thair Is Compild (The Flyting of Dumbar and Kennedie)', in Jacqueline Tasioulas (ed.), The Makars: The Poems of Henryson, Dunbar and Douglas (Edinburgh, 1999), v. 22, 1. 172, p. 347; David Lindsay, The Poetical Works of Sir David Lyndsay, ed. David Laing, 3 vols. (Edinburgh, 1879), i, 1. 16, p. 1. See Keely Fisher, 'The Crying of Ane Play: Robin Hood and Maying in Sixteenth-Century Scotland', in John Pitcher (ed.), 
Stories originating from Scotland presented a fairly broad range of ghosts. In 1547, David Lindsay imagined the return of the murdered Cardinal Beaton. He appeared 'rycht suddantlie', in the form of

Ane woundit man, aboundantlie bledyng, With vissage paill and with ane deidlye cheir In rayment reid cloithit full curiouslie, Of vellvoit, and of satyn crammosie.

With febyll voce, as man opprest with paine, ${ }^{12}$

The unhappy ghost returned to admit a multitude of misdemeanours (Lindsay was using it to comment on ecclesiastical corruption). This ghost fitted many common medieval patterns, being corporeal, bleeding, clad in red, and keen to confess its sins. However, the notion of luminous silvery apparitions also existed in Scotland, at least by the sixteenth century and probably before. George Buchanan's Rerum Scoticarum Historia, published in 1582, told of a cunning plan executed in the mid-ninth century by Kenneth II (Kenneth I by modern historians' reckoning). Kenneth needed the support of his nobles to raise an army. He clothed a young man in fish skins and had him appear to the nobles and exhort them to war, speaking through a tube to amplify his voice. Buchanan explains that 'the sudden flashing of light from the fishes skins, darting about [the nobles'] drowsie eyes and dazling them, drove them into great astonishment', and 'a kind of religious consternation seized upon their minds'. The boy vanished by the means of a secret passage, and the nobles promptly agreed to the war. $^{13}$

The same apparition might be presented in very different ways. In the 1440 s Walter Bower wrote of a possible ghost at the second wedding of Alexander III. This wedding took place in 1285, while many Scots were suffering from famine. A show

Medieval and Renaissance Drama in England, Vol. 12 (Cranbury, 1999), 44-6; William Henry Schofield, Mythical Bards and The Life of William Wallace (Cambridge [Mass.], 1920), 41-3.

12 Lindsay, Poetical Works, i, 11. 17-22, p. 140. 'Cheir' translates as 'look', 'countenance' or 'demeanour'; 'crammosie' translates as 'crimson'.

13 George Buchanan, Rerum Scoticarum Historia, ed. Dana F. Sutton, electronic edn (University of Birmingham, 2009), http://www.philological.bham.ac.uk/scothist, accessed 1 Aug. 2015, bk. v, para. 56. 
was put on, and included a procession that wound its way among the guests. At the rear came a figure that might have been a man or an apparition (fantasma). It seemed to glide rather than walk. Then it disappeared. The procession halted, and the music and dancing ceased. The text noted that 'laughter is always mixed with grief, and mourning takes over from extremes of joy'. ${ }^{14}$ In his 1527 Historia Gentis Scotorum, Hector Boece retained the melancholy message of the spectre, but presented it in a different guise. He explained that the plague had killed many Scots people in the years prior to the wedding, then noted that when the bridegroom was leading the bride to dance, a dead man with no flesh on his bones was seen bringing up the rear. This ill omen put an end to all celebration. ${ }^{15}$ Boece's version of the apparition was reminiscent of the skeletons in the Danse Macabre, and presented a more grisly reminder of death than Bower's ambiguous spectre.

Revenants could also be found in Scotland. Nancy Caciola outlines a twelfth-century case, about a chaplain from Melrose Abbey who returned to pay his attentions to his former mistress. She recruited some young men, who lay in wait and killed the revenant with an axe as it returned to its grave. The grave was later opened, and the wound was still fresh. The locals then burned the corpse. ${ }^{16}$ The northern English Chronicon de Lanercost recorded two more Scottish cases, this time from the 1290s. One concerned a deceased monk who haunted a knight, Sir Duncan de Insula, near Paisley:

Now there was a certain fellow wearing the garments of holy religion who lived wickedly and died most wretchedly, being bound by sentence of excommunication ... Long after his body had been buried, it vexed many in the same monastery by appearing plainly in the shade of night. This child of darkness proceeded to the house of the said knight in order to disturb the faith of simple persons and terrify them by molesting them in broad daylight, or, more probably, by a secret decree of God, that he might indicate by such token those who were implicated in his misdoing. Having then assumed a bodily shape (whether natural or aerial is

14 Nicola Royan and Dauvit Broun, 'Versions of Scottish Nationhood, c.850-1707', in Ian Brown et al. (eds.), The Edinburgh History of Scottish Literature, Vol. 1: From Columba to the Union (until 1707) (Edinburgh, 2007), 172-3.

15 Hector Boethius, Scotorum Historia, ed. Dana F. Sutton, electronic edn (University of Birmingham, 2010), http://www.philological.bham.ac.uk/boece, accessed 1 Aug. 2015, bk. xiii, para. 84 .

16 Caciola, 'Wraiths, Revenants, and Ritual', 21. 
uncertain, but it was hideous, gross and tangible) he used to appear at noon-day in the dress of a black monk and settle on the highest parts of the dwellings or store houses ... Also he so savagely felled and battered those who attempted to struggle with him as well-nigh to shatter all their joints. ${ }^{17}$

In the end, the revenant killed the family's heir. The other story was from the historic district of Cunninghame in Ayrshire. It told of how God taught a drunkard to mend his ways by terrifying him with a visitation from 'an exceedingly hideous likeness of a spirit of the air ... with a foul body, ghostly countenance, fiery eyes and of terrific dimensions'. ${ }^{18}$ The apparition was identified as the owner of a nearby tavern. He was not obviously dead, but drew on revenant traditions nonetheless; if the 'spirit of the air' conjures up notions of incorporeality, they are swiftly dispelled by the huge 'foul body' with its burning eyes.

Just as the dead could return in a range of forms, interpretations of apparitions varied. There was some doubt over how far ghost stories ought to be credited. In the prologue to his translation of The Aeneid (1513), Gavin Douglas noted that his readers would complain:

'All is but ghaists and eldritch fantasies,

Of brownies and of bogles full this book:

Out on thir wandering spirits, wow!' thou cries. ${ }^{19}$

He suggested that people would scoff at these 'vain superstitions against our richt belief' ${ }^{20}$ This vision of ghosts as a vulgar superstition would reappear frequently over the following centuries, but it was just one of several possible approaches. Two alternatives can be seen in the pair of spectres discussed in Blind Harry's The Actes and Deidis of the Illustre and Vallyeant Campioun Schir William Wallace, written in the 1470s. The first was the ghost of Fawdon. Fawdon was one of sixteen men with whom Wallace fled from the English, after a battle in which they were vastly

17 Herbert Maxwell (ed.), The Chronicle of Lanercost, 1272-1346, trans. Herbert Maxwell (Glasgow, 1913), 118-19; see Caciola, 'Wraiths, Revenants, and Ritual', 24.

18 Maxwell, Chronicle of Lanercost, 75-6.

19 Gavin Douglas, The Aeneid (1513), ed. Gordon Kendal (London, 2011), prologue VI, 11. 17-19, p. 237. 'Eldritch' tended to mean 'elvish' or 'fairy-like', but could also refer to the supernatural more broadly.

20 Ibid., 1. 22, p. 237 
outnumbered. After they had gone a little distance Fawdon grew tired, and protested that he was not able to go any further. Angered, Wallace drew his sword and sliced off Fawdon's head. In defence of this brutality the text suggested that Fawdon might have been a traitor, noting that he was strong, they had not gone far, and he was commonly held to be fickle ('of brokill complexioun'). Nonetheless, retribution awaited Wallace. When he and his remaining men reached their stronghold at Gask Hall, they heard the sound of blaring horns. Wallace sent two men to investigate. When they did not return he sent two more, and then dispatched the others in turn until he was left alone. He was forced to draw his sword and leave the hall himself. Outside he saw Fawdon, holding his own decapitated head. Wallace crossed himself, and Fawdon flung the head at him, which he caught and threw back. His heart 'gretlye agast', Wallace ran away up the stairs and jumped out of a window, making his retreat along a riverbank. Glancing back he thought he saw Fawdon once more, holding a great rafter, having set the hall on fire. ${ }^{21}$

Later in The Wallace, Harry presented a very different ghost. An old monk who had lived a good life promised a younger monk that, if God permitted it, he would return after his death to report on the afterlife. God allowed him to keep his word. He returned from Purgatory, radiating light and with a firebrand in his forehead, and explained that Wallace was shortly to go to Heaven. ${ }^{22}$ The spectres of Fawdon and the monk may have both been the apparitions of returning dead people, but their similarities ended there, and Harry interpreted them differently. The monk, come to perform a noble duty by honouring Wallace, had been genuinely allowed to return by God. The malicious Fawdon, on the other hand, was recognised by Wallace as a demon:

Rycht weill he trowit that was no spreit of man; It was sum devill at sic malice began. ${ }^{23}$

21 Hary, The Wallace: Selections, ed. Anne McKim, electronic edn (Medieval Institute Publications, 2003), http://d.lib.rochester.edu/teams/publication/mckim-the-wallace-selections, accessed 1 Aug. 2015, bk. iv, 11. 91-120, 11. 174-209; quotations 1. 116, 1. 198. See John Balaban, 'Blind Harry and "The Wallace", Chaucer Review, viii (1974), 248-9 on possible Celtic sources for Fawdon's apparition.

22 Hary, Wallace, bk. xii, 11. 1238-99.

23 Ibid., bk. v, 11. 199-200. 'Trowit' translates as 'believed'; see editorial notes. 
Later Blind Harry speculated on possible explanations for the apparition. He noted that it could be the work of the Devil, and also recalled a notion found in Dante's Inferno (1317), that demons could take over the bodies of traitors once their souls had departed:

gif the man endyt in evill entent,

Sum wikkit spreit agayne for him present; ${ }^{24}$

The apparition of Fawdon was in the revenant tradition, with its physicality and violence, and it was common for revenants to be interpreted as demons inhabiting corpses. Again, however, this interpretation was not universal. The violent black-clad monk described above had probably been allowed to wander by God, but as Caciola notes, 'there is no question of demonic possession or reanimation by anything other than the creature's own residual life-force' ${ }^{25}$

Overall, medieval apparitions could appear in a range of different guises and for a variety of reasons. Nonetheless, there were some particularly common patterns in the European sources, and the limited evidence does not suggest that Scotland was markedly different. The typical ghost was corporeal, returned in the clothes it had worn during its lifetime, and retained some link to its dead body. Its appearance made some moral, usually religious, point. There was no guarantee, however, that an apparition would be understood as a returning dead person, despite the fact that this interpretation was theologically defensible by the late Middle Ages. Ghosts could be dismissed as a mere superstition, or interpreted as demons. The figure of the ghost was certainly recognised in medieval Scotland, but this does not mean that ghosts had an unequivocal place within religious culture.

24 Ibid., bk. v, 11. 221-2. The point about Dante is from Matthew P. McDiarmid's edition, referenced by McKim, bk. v, 219-24n.

25 Caciola, 'Wraiths, Revenants, and Ritual', 24. 


\section{The Reformation}

If the correct interpretation of ghosts was ambiguous before the Reformation, it theoretically became clearer thereafter. Protestantism stripped away Purgatory, and for most theologians, this meant that ghosts could not exist. It was generally agreed that it was impossible to leave Hell, and that nobody would ever choose to leave Heaven. In 1569 the Swiss theologian Ludwig Lavater published his De Spectris, Lemuribus et Magnis Atque Insolitis Fragoribus (the English edition, Of Ghostes and Spirites Walking by Nyght, appeared in 1572). Lavater explained that those who were 'thinking every small motion and noyse to be spirites' and those who were 'fondely perswaded that there are no spirites' were equally in error. ${ }^{26}$ However, the idea of dead souls in an intermediary state was a Catholic deception. Most apparitions were the result of trickery, error, or the hallucinogenic fumes of melancholy. Remaining apparitions were either angels or, more usually, demons. The raising of Samuel was no more than a trick by devils. ${ }^{27}$ The work was widely read and discussed, and translated into five languages. Lavater probably did more than any other author to establish the new Protestant orthodoxy on ghosts.

Prominent Catholics upheld the reality of ghosts in the face of Protestant challenges. Dense theological works defended the doctrine of Purgatory, often with reference to apparitions. ${ }^{28}$ Collections of stories claimed to demonstrate the reality of ghosts. The best known works of this type were the 1586 Discours et Histoires des Spectres, Visions, et Apparitions des Esprits by Pierre Le Loyer, and the 1588 Psichologie, ou Traité de l'Apparition des Esprits by Noel Taillepied. In fact, as Timothy Chesters and Amanda Jane McKeever argue, there was not much to choose between Lavater's interpretation and those of Le Loyer and Taillepied. ${ }^{29}$ All three men discussed a common set of circumstances - ignorance, drunkenness, illness, an over-active

26 Ludwig Lavater, Of Ghostes and Spirites Walking by Nyght, trans. Robert Harrison (London, 1572, STC 15320), 16.

27 Ibid., 74-7.

28 R. C. Finucane, Ghosts: Appearances of the Dead and Cultural Transformation (Amherst [N.Y.], 1996), 97.

29 Timothy Chesters, Ghost Stories in Late Renaissance France: Walking by Night (Oxford, 2011), ch. 2; Amanda Jane McKeever, 'The Ghost in Early Modern Protestant Culture: Shifting Perceptions of the Afterlife, 1450-1700' (University of Sussex DPhil thesis, 2010), 117-36. 
imagination - that could cause people to imagine apparitions. Women, children, the elderly and the infirm were thought to be especially susceptible. In addition, all three men asserted that the Devil or demons sometimes pretended to be ghosts. The important difference was that both Le Loyer and Taillepied asserted that sometimes, albeit rarely, apparitions were indeed the returning spirits of the dead. The fact that the three theologians would probably have agreed in most cases did not prevent Protestants from making much of Catholic ignorance and credulity on the subject of apparitions, often blaming hauntings on the machinations of greedy priests. The Catholics earned an undeserved reputation as the defenders of all ghost stories, no matter how fantastical. ${ }^{30}$

Scotland's Reformation was instigated by the Scottish parliament in 1560 . The Catholic Mary Queen of Scots was forced to abdicate seven years later in favour of her one-year-old son, who became James VI. After an unsuccessful attempt to regain her throne she fled to England, where she was kept in custody by Elizabeth I until her execution in 1587. Aside from her abortive resistance, there was little in the way of a Catholic counter-movement, and Scotland's religious scene in the following decades was defined more by disagreement between different Protestant factions than by rivalry between Protestants and Catholics. ${ }^{31}$ Nonetheless, there was a concerted effort to stamp out the remnants of Catholicism, with public office being restricted to orthodox Protestants and kirk sessions imposing strict discipline on Scottish parishes. ${ }^{32}$ Within this context, the new king became the most important Scottish proponent of the Protestant interpretation of ghosts. James was a erudite ruler: he wrote treatises on kingship, literary theory, and, significantly, demonology. His 1597 Daemonologie focused primarily on witchcraft and the wiles of the Devil. However,

30 On the undeserved nature of this reputation see Francis Young, English Catholics and the Supernatural, 1553-1829 (Farnham, 2013), which argues that 'the post-Reformation Catholic community was not preoccupied with ghosts to a greater extent than anyone else in the population' (79).

31 See Jenny Wormald's description of the 'remarkable success story' of the new kirk in Jenny Wormald, Court, Kirk, and Community: Scotland, 1470-1625 (Edinburgh, 1991), 132-39 (quotation 133).

32 Julian Goodare, 'Scotland', in Bob Scribner, Roy Porter, and Mikuláš Teich (eds.), The Reformation in National Context (Cambridge, 1994); Michael Lynch, 'Preaching to the Converted? Perspectives on the Scottish Reformation', in A. A. MacDonald, M. Lynch, and I. B. Cowan (eds.), The Renaissance in Scotland: Studies in Literature, Religion, History and Culture (Leiden, 1994). 
James also gave some space to ghosts, under the labels 'spectra' and 'umbrae mortuorum'. His stance was that all such spirits were actually demons or emanations of the Devil. He divided spirits into several categories:

That kinde of the Devils conversing in the earth, may be divided in foure diffrent kindes, whereby he affrayeth and troubleth the bodies of men ... The first is, where spirites troubles some houses or solitarie places: The second, where spirites followes upon certaine persones, and at divers houres troubles them: The thirde, when they enter within them and possesse them: The fourth is these kinde of spirites that are called vulgarlie the Fayrie. ${ }^{33}$

He added: 'doubtleslie they are in effect, but all one kinde of spirites, who for abusing the more of mankinde, takes on three sundrie shapes, and uses diverse formes of out-ward actiones'. He explained that these demons might appear as incorporeal spirits, or might choose to borrow a dead body. ${ }^{34}$ James, in fact, went further than Lavater. He did not allow for the appearance of angels or good spirits, and asserted that no miracles had been performed since biblical times. ${ }^{35}$ Any kind of spectral apparition was demonic by James's definition, just as any kind of magical capability implied a pact with the Devil.

Aside from James VI, few Scottish authors wrote about ghosts before the late seventeenth century. When ghosts did appear they were usually interpreted according to James's template, and associated with Catholicism. William Birnie, minister of Lanark from 1597, wrote a treatise arguing against kirk burial in 1606. He explained that many Catholic errors stemmed from those of the 'olde Heathen', who 'became plunged in infinite errors anent the estate of the dead'. These heathens divided the world into good and bad men, and then subdivided each estate into two categories.

33 James VI, 'Daemonologie, in Forme of Ane Dialogue', in James Craigie and Alexander Law (eds.), Minor Prose Works of King James VI and I (Edinburgh, 1982), bk. iii, ch. i, 39-40.

34 Ibid., 40, 41.

35 Ibid., 45. On Protestants and miracles see D. P. Walker, 'The Cessation of Miracles', in Ingrid Merkel and Allen. G. Debus (eds.), Hermeticism and the Renaissance: Intellectual History and the Occult in Early Modern Europe (Washington, 1988); Alexandra Walsham, 'Miracles in PostReformation England', in Kate Cooper and Jeremy Gregory (eds.), Signs, Wonders, Miracles: Representations of Divine Power in the Life of the Church (Woodbridge, 2005); Jane Shaw, Miracles in Enlightenment England (New Haven, 2006); R. M. Burns, The Great Debate on Miracles: From Joseph Glanvill to David Hume (London, 1981); Philip M. Soergel, Miracles and the Protestant Imagination: The Evangelical Wonder Book in Reformation Germany (New York, 2012). 
The best of the good became gods. The lesser good folk experienced some of the Elysian fields, but were also required to serve mankind as benevolent spirits; they were known as 'Lares', or 'Brunies' (brownies) in Scots. The worst of the bad men were 'assigned the pitte of Pluto for prison'. However, 'the next were the not so bad: who being not Lares, but Laurae or Lemures, that is, bogils or Gaistes, were by the world adjudged to such a purgatoriall pennance, that wandring in a vagarant estate about graves and alrish deserts, they were suspended till their pennance was ended from elisean repose'. These pagan beliefs remained 'in hote tread' among the Catholics. ${ }^{36}$ Birnie's picture was based on ancient Roman ideas, revisited during the Renaissance, which presented Lares as the spirits of the good dead and Lemures or Larvae as the spirits of the wicked. ${ }^{37}$ In fact, this bore little relation to medieval accounts of ghosts, but Birnie achieved his purpose: ghosts were placed in an unorthodox, un-Christian world, as well as being entangled with notions of Purgatory. Later, Birnie also linked ghosts to superstitious folk culture, complaining that kirk burial meant that 'Gods seemely sanctuarie ... becommeth in populare opinion thereby the alrishe Innes of bogles and Gaists. So that many for that presumed feare dare not enter alone in the Kirk. ${ }^{38}$

About a decade later, a Stirling minister called Patrick Simson offered an equally critical analysis. He explained that 'visions, dreames and apparitions' constituted one of the three pillars used by Catholics to support Purgatory, and added:

In end, Purgatorie finding no sure allowance in scripture, nor yet in the writings of ancient fathers began to creepe under the skirts of apparitions of dead men \& by dreames, fables, apparitions and foolish inventions it was so strengthened, that the verity of the Gospel was not so much regarded by a foolish bewitched people as the fables confirming Purgatorie. ${ }^{39}$

William Guild, a minister of Aberdeen and theological writer, similarly wrote in 1655

36 William Birnie, The Blame of Kirk-Buriall, Tending to Perswade Cemiteriall Civilitie (Edinburgh, 1606, STC 3089), ch. xii. 'Alrish' is an alternative form of 'eldritch'.

37 See Armando Maggi, In the Company of Demons: Unnatural Beings, Love, and Identity in the Italian Renaissance (Chicago, 2006), 9-12, 94-8, 128-9.

38 Birnie, Blame of Kirk-Buriall, ch. xvii.

39 Patrick Simson, A Short Compend of the Historie of the First Ten Persecutions Moved against Christians Divided into III. Centuries, 3 vols. (Edinburgh, 1613-1616, STC 23601), i, cent. III, 'A Treatise of Purgatorie and Prayer for the Dead'. 
and 1656 of 'apparitions of soules' being a Catholic superstition, arguing through biblical quotation that such visions proceed 'from the fraud and deceat of the devill'. ${ }^{40}$ The minister Alexander Wedderburn (c. 1620-78) offered an unusually sympathetic picture, arguing that God had sent the dead souls of Moses and Elijah from Heaven to Earth for the Transfiguration, but nonetheless dismissed Catholic ghost stories. God had the power to restore the dead, but 'that it is his Will so to do, or that it is now needfull to be done, is that which [Popish writers] can never prove'. ${ }^{41}$ Demons, on the other hand, were thought to have free rein to travel as they wished. The Glaswegian minister James Durham explained in 1658: 'That there are evill spirits rangeing up and down through the earth is certain, even though hell be their prison properly, yet have they a sort of dominion and abode both in the earth and air'. ${ }^{42}$

Similar patterns can be seen in poetry. The Bannatyne Manuscript, a sixteenthcentury anthology, included an anonymous and undated poem that explained how to lay a ghost. Burlesque in style, it presented an early case of a ghost "wyne in ane wynden schet', and described a complex ceremony for laying a ghost, involving ten foxes' tails, holy water, snuff, a dog's ear, some blue wool, and other miscellaneous artefacts. The ghost was to be addressed as follows:

Litill gaist, I conjure the,

With liorie and larie,

Bayth fra God, and Sanct Marie,

First with ane fishis mouth,

And syne with ane sowis towth,

With ten pertane tais,

And nyne knokis of windil strais,

With thre heids of curle doddy. ${ }^{43}$

40 William Guild, Anti-Christ Pointed and Painted Out in His True Colours (Aberdeen, 1655), 164; William Guild, An Answer to a Popish Pamphlet Called The Touch-Stone of the Reformed Gospell (Aberdeen, 1656), 223.

41 Alexander Wedderburn, Heaven upon Earth, Or, The History of the Transfiguration of Jesus Chirst Opened (Edinburgh, 1703), 157-8.

42 James Durham, A Commentarie upon the Book of the Revelation (Edinburgh, 1658), 679.

43 This poem is recorded by Walter Scott in Appendix V to The Minstrelsy of the Scottish Border. The version in The Poetical Works of Sir Walter Scott, Bart., ed. J. G. Lockhart, 12 vols. (Edinburgh, 1833-4), i, 265-9 has fuller annotations than earlier editions of the Minstrelsy. Scott translates 'liorie and larie' as 'with laying and with lore' and 'ten pertane tais' as 'ten crabs' claws'. He also notes that a 'curle doddy' is a small plant found in marshes. The DSL defines a 
At the end of this speech the sign of the cross should be made, and the ghost would disappear, never to return. The poem mocked Catholic ritual, and arguably also Catholic ghost traditions. The ghost itself was associated with a fantastical folkloric world; later in the poem it married the 'Spenzie fle' and fathered 'Orpheus King and Elpha Quene'. ${ }^{44}$ Another two works, both from the 1580s, similarly placed ghosts in a realm of vulgar superstition. In 'The Legend of the Bischop of St. Androis Lyfe', a lampoon against Archbishop Patrick Adamson, Robert Sempill presented a witch riding out with fairies, nature spirits and dead neighbours:

Ane carling of the Quene of Phareis, That ewill win geir to elphyne careis. Through all Braid Abane scho hes bene On horsback, on Hallow ewin;

And ay in seiking, certayne nyghtis, As scho sayis, with our sillie wychtis; And names out nychtbouris sex or sewin, That we belevit had bene in heawin. ${ }^{45}$

Secondly, as part of a flyting with the Catholic Alexander Montgomerie, Patrick Hume of Polwart declared:

Thy speach but purpose, sporter, is espyed,

That wrytes of witches, warlocks, wraiths, and wratches;

But invectives against him well defyed,

Rob Steuin, thou raves, forgetting whom thou matches.

Leave boggles, brownies, gyr-carlings and gaists:

Dastard, thou daffes, that with such divilrie mels. ${ }^{46}$

In these two extracts, ghosts were associated with even more theologically questionable beliefs such as brownies, fairies and ogres. There was also a demonic

'windil stray' as a 'withered stalk of grass'. 'Wyndil(1) stray n.', DSL (Scottish Language Dictionaries, 2004), http://www.dsl.ac.uk/entry/dost/wyndill_stray, accessed 1 Aug. 2015.

44 Scott translated the 'Spenzie fle' as the 'Spanish fly'. Scott, Poetical Works, 269.

45 Quoted in Julian Goodare, 'The Cult of the Seely Wights in Scotland', Folklore, cxxiii (2012), 206-7. See also David J. Parkinson, "The Legend of the Bischop of St. Androis Lyfe" and the Survival of Scottish Poetry', Early Modern Literary Studies, ix (2003), 5.1-24.

46 Alexander Montgomerie and Patrick Hume, 'The Flyting Betwixt Montgomery and Polwart', in James Cranstoun (ed.), The Poems of Alexander Montgomerie (Edinburgh, 1887), 11. 657-662, pp. 81-2. See Jacqueline Simpson, “The Weird Sisters Wandering”: Burlesque Witchery in Montgomerie's Flyting', Folklore, cvi (1995), 9-20. 
undertone: Sempill linked them to an old woman who brought evilly obtained goods to fairyland, while Hume used the term 'divilrie'. As we have seen, depicting ghosts as a vulgar superstition or a diabolic trick was possible in the medieval period as well, but it became a more dominant pattern following the Reformation.

Alternative interpretations of apparitions were rare, but not unheard of. One example can be seen in the work of Paracelsian physician and antiquarian Christopher Irvine (c. 1620-93). In Medicina Magnetica: Or, the Rare and Wonderful Art of Curing by Sympathy (1656), Irvine outlined his theory on vital human spirits, which (he argued) lent a curative power to the flesh and blood of the freshly dead. Those who had died violent deaths were particularly potent. ${ }^{47}$ Irvine explained that the soul could still perform some operations after death, whether because it was 'not utterly and absolutely free as long as any vital spirit remaineth any where safe and untoucht' or simply because it could function without the 'instruments of its proper natural heat'. He continued:

But of what hath been said the cause is plain, why about the Graves of them that die a violent death there are apparitions seen: for the vital heat and natural moisture being not quite dissolved, the soul sticks, and gives sometimes in these exhallations, impregnated with the spirit, the shape and form of a man: And the same may be the reason, why sometimes in Church-yards such things appear: and from the same head it is, that the slain Corps bleedeth at the presence or touch of the Murderer: for, the soul being yet present, doth by the dispensation of Providence, work such things. ${ }^{48}$

As we have seen, Lavater suggested that melancholy or drunkenness could lead one to see apparitions. James VI generally distrusted this explanation, but did suggest that melancholy might be behind werewolf stories. ${ }^{49}$ In 1678 George Mackenzie argued that 'the fumes of wine or melancholy will represent strange apparitions, and make us think them real'. ${ }^{50}$ Nonetheless, at the time it was unusual to focus so heavily on

47 See Richard Sugg, Mummies, Cannibals, and Vampires: The History of Corpse Medicine from the Renaissance to the Victorians (Abingdon, 2011), 49; Sarah Tarlow, Ritual, Belief and the Dead in Early Modern Britain and Ireland (Cambridge, 2011), 159-61.

48 Christopher Irvine, Medicina Magnetica: Or, the Rare and Wonderful Art of Curing by Sympathy ([Edinburgh], 1656), 16-17.

49 James VI, 'Daemonologie', bk. iii, ch. i, 42.

50 George Mackenzie, The Laws and Customes of Scotland, in Matters Criminal (Edinburgh, 1678), 98. 
physiology in explaining apparitions (as well as the bleeding corpse, which shall be discussed further below). Admittedly, Irvine still owned the importance of the 'dispensation of Providence', so his account was not wholly devoid of supernatural elements. It constituted a middle-ground between supernatural and rational interpretations of spirits: the apparition remained a dead soul, but it appeared through physiological functions rather than for theological reasons. Irvine's approach was an interesting one, but it did not really represent an alternative trend in interpreting apparitions. It was not until the eighteenth century that physiological explanations for ghosts appeared frequently. In the late sixteenth and seventeenth centuries, the demonic explanation remained predominant.

\section{Surviving Ghost Stories}

Although apparitions were usually depicted as demons or Catholic errors, they did not disappear from educated culture altogether. One well-known story was recorded by two sixteenth-century Scottish historians, the aforementioned George Buchanan and Robert Lindsay of Pitscottie. Both were Protestants. Buchanan served as a tutor to both Mary Queen of Scots and James VI, and was Moderator of the kirk's General Assembly in 1567. Robert Lindsay did not hold such influential posts as Buchanan, but he is remembered for producing the first history of Scotland to be written in Scots. His Historie and Cronicles of Scotland was completed in the late 1570s or early 1580s, but remained unpublished until 1728. Nonetheless, it seems to have been well known; W. W. Scott notes that at least sixteen manuscript versions survive, and that continuations up to 1603 were produced. ${ }^{51}$ The story began with James IV and a party of lords at church in Linlithgow, preparing to set out for the battle of Flodden (9 Sept. 1513). While James was in prayer, another figure entered the church and approached him. Lindsay described his appearance as follows:

there came a Man clad in a blue Gown in at the Kirk Door, and belted about him in a Roll of Linen Cloth; a Pair of Brotikins on his Feet, to the Great of his Legs,

51 W. W. Scott, 'Lindsay, Robert, of Pitscottie (c.1532-c.1586)', Oxford DNB (Oxford University Press, 2004), http://www.oxforddnb.com/view/article/16715, accessed 1 Aug. 2015. 
with all other Hose and Clothes conform thereto; but he had nothing on his Head, but syde red yellow Hair behind, and on his Haffits, which wan down to his Shoulders; but his Forehead was bald and bare. He seemed to be a Man of two and fifty Years, with a great Pyke Staff in his Hand, ${ }^{52}$

In Buchanan's version the figure was 'an old man, the hair of his head being red inclining to yellow and hanging down on his shoulders, his forehead sleek thro' baldness, bare-headed, in a long coat of a russet colour, girt with a linen girdle about his loins'. ${ }^{53}$ He reached James, and in Lindsay's version he declared, with 'little Reverence or Salutation':

Sir King, my Mother hath sent me to you, desiring you not to pass, at this Time, where thou art purposed; for, if thou does, thou wilt not fare well in thy Journey, nor none that passeth with thee. Further, she bade thee mell with no Woman, nor use their Counsel, nor let them touch thy Body, nor thou theirs; for, if thou do it, thou wilt be confounded and brought to Shame.

He gave a very similar warning in Buchanan's text. The king hesitated, and according to Lindsay the man then 'vanished away, and could noways be seen nor comprehended, but vanished away as he had been a Blink of the Sun, or a Whip of the Whirlwind'. ${ }^{54}$ James went on to Flodden and was killed.

Robert Mackie speculated that this incident might have been engineered as an antiwar stunt, although Norman Macdougall casts doubt on the idea that there was ever a notable anti-war faction. ${ }^{55}$ However, there is really no need to look for rational explanations: the story might well have been devised only after James's death. The mysterious, prophetic warning, the moralising reflection on James's partiality for mistresses, and the dramatic disappearance were all familiar narrative elements; a story of this sort could circulate regardless of whether or not there happened to be any truth in it. This apparition was not necessarily a returning dead person, but nor

52 Robert Lindsay, The History of Scotland: From 21 February, 1436 to March, 1565 (Edinburgh, 1728), 111.

53 Buchanan, Rerum Scoticarum Historia, bk. xiii, para. 23.

54 Lindsay, History of Scotland, 111.

55 R. L. Mackie, King James IV of Scotland: A Brief Survey of His Life and Times (London, 1976), 264-5; Norman Macdougall, James IV: The Stewart Dynasty in Scotland (Edinburgh, 2006), $265-6$. 
was it presented as a demon. Perhaps as a result, Buchanan was cautious about including the story in his history. He noted that one of those present was the poet David Lindsay of the Mount, 'a man of approved worth and honesty (and a great scholar too)'. He explained that 'if I had not received this story from him as a certain truth, I had omitted it as a romance of the vulgar'. ${ }^{56}$ Nonetheless, the story seems to have been popular. It is interesting to note that when George Sinclair republished it in his 1685 Satan's Invisible World Discovered, details had been added or modified. The precise church was specified, and the man was described as 'an Ancient Man ... his Amber coloured Hair hanging down upon his Shoulders, his forehead high, and inclining to Baldness, his Garments of Azure colour, somewhat long, girded about with a Towel, or Table-Napkin, of a Comely and very Reverend Aspect'. ${ }^{57}$ The apparition did not mention his mother, and the reference to touching women's bodies was toned down into a recommendation that James should not make use of the 'company' of women. This suggests that the story had circulated and been retold in the hundred years after the deaths of Lindsay and Buchanan.

Buchanan and Lindsay also wrote of how James V, having had James Hamilton of Finnart executed on a charge of treason, was later visited by Hamilton's apparition. In Buchanan's words: 'in his sleep he saw James Hamilton running at him with his drawn sword, and that he first cut off his right arm, then his left, and threatned him shortly to come and take away his life, and then disappeared'.58 The king's two sons died soon afterwards. This story was also given by John Knox in his history of the Scottish Reformation, written in the late 1550s and early 1560s. In addition, Knox wrote of a second vision, related to the same affair: the justice clerk Thomas Scott of Balwearie appeared moments after his death in the company of devils, and declared to the king: ' $O$ wo to the day that ever I knew thee or thy service; for serving of thee, against God, against his servants, and against Justice, I am adjudged to endlesse torment' ${ }^{59}$ Knox's Protestant credentials are hardly in doubt, but he was seemingly

56 Buchanan, Rerum Scoticarum Historia, bk. xiii, para. 23.

57 George Sinclair, Satan's Invisible World Discovered (Edinburgh, 1685), 39.

58 Buchanan, Rerum Scoticarum Historia, bk. xiv, para. 47; Lindsay, History of Scotland, 167-8.

59 John Knox, The History of the Reformation of the Church of Scotland (London, 1644), bk. i, 25. On Balwearie's supernatural associations see Julian Goodare, 'The Scottish Witchcraft Panic of 1597', in Julian Goodare (ed.), The Scottish Witch-Hunt in Context (Manchester, 2002), 58-9. 
ready to countenance ghost stories when they suited his own purposes - in this case, highlighting the impiety of Catholic kings.

Knox was writing before the publication of Louis Lavater's work on ghosts, and all three of these writers pre-dated James VI's Daemonologie. Even after the publication of Daemonologie, however, ghosts made occasional appearances. David Person, who described himself as being a gentleman from the Lowlands, produced a 1635 text entitled Varieties: Or, A Surveigh of Rare and Excellent Matters Necessary and Delectable for All Sorts of Persons. The text covered a diverse range of subjects, including the nature of the Earth, sun, moon, stars, sea and meteors; battles and duels; laughing and mourning; 'divine Philosophy'; sleep and dreams; death, miracles and prodigies; the Philosopher's Stone; metaphysics; and the numbers three and seven. As part of his discussion of death, Person explained that poets 'affirme that the spirits and Manes of them who want their due burialls, wander here and there in Ghostly apparitions untill their bones be interred'. ${ }^{60} \mathrm{He}$ added that 'the punishment of the neglect of it may appeare in one of our Northern Countries', and proceeded to tell a story from Lauder. A woman on her deathbed beseeched her husband to bury her in the churchyard, 'which if hee did not, shee threatned that her Ghost would haunt him after her death'. However, there was an outbreak of the plague at the time. The man feared that if he buried her publicly his friends would suspect that she had been infected, and would break off contact with him. He therefore concealed her death, burying her in a corner of his garden. Person explains: 'thereafter, this womans ghost, I say, did so incessantly both haunt and affright, both him, his children, and family, that there was no resting for them at any time; till by the advise of the Clergy she was taken up againe and buried, where she desired to be in her lifetime; which being done, both she and they rested'. ${ }^{61}$ This was in line with medieval ghost traditions, which held that ghosts might return because of irregularities in their burials. Person's work was a motley collection on all kinds of different topics, but it is nonetheless interesting to note that a ghost story could still be presented seriously

60 'Manes' was another term for departed spirits in Roman mythology. For a discussion of them see Charles W. King, 'The Roman Manes: The Dead as Gods', in Mu-chou Poo (ed.), Rethinking Ghosts in World Religions (Leiden, 2009).

61 David Person, Varieties: Or, A Surveigh of Rare and Excellent Matters Necessary and Delectable for All Sorts of Persons (London, 1635, STC 19781), 165. 
in a quasi-scientific treatise.

Even the kirk seems to have had occasional doubts about how to handle ghosts. In 1666 some inhabitants of South Ronaldsay, Orkney, were troubled with dreams and apparitions of four fisherman who had died at sea. They claimed to have been murdered. After their widows appealed to the minister, he went with the baillie and the session to inspect the graves, and those who had found the bodies were required to handle them (more on this presently). ${ }^{62}$ No evidence of wrongdoing was discovered, but it is interesting that these steps were taken at all. Just over a decade later, in December 1675, the Leith kirk session recorded the following:

Compeared James Dempster and declared against John Robertson (whose wife died about six weeks ago and being thrice proclaimed upon Janet Trotter was intended to be married this day) that his wife's ghost hath severall tymes appeared to him and commanded him to go to the ministers and session and beg that his marriage might be stopt, averring that the said John had murthered his wife and brybed him with half a crown and promised him some more to hold his peace. ${ }^{63}$

The entry went on to explain that 'the business being criminall the session referred it to the baillies'. Both the kirk session and the baillies were apparently prepared to take ghosts seriously. It is also worth noting the sentence cast on five prisoners convicted of treason for their part in the Battle of Bothwell Bridge (22 June 1679). The battle was waged between Covenanters and the Episcopalian government. The month before a group of militant Covenanters had murdered Archbishop Sharp, who was held responsible for Presbyterian repression. The five prisoners were not involved, but were declared accessories because they expressed a sympathetic attitude towards the crime. In November 1679 the judges sentenced the men to execution and declared that they should be 'hanged up in chains in Magus-moor, to expiate and appease the Archbishop's ghost, who was there murdered' ${ }^{64}$ The judges may not have been referring to a literal ghost, but their sentence nonetheless

62 J. B. Craven, Church Life in South Ronaldshay and Burray in the Seventeenth Century (Kirkwall, 1911), 53.

63 David Robertson (ed.), South Leith Records, Compiled from the Parish Registers for the Years 1588 to 1700 (Edinburgh, 1911), 133.

64 John Lauder (ed.), The Decisions of the Lords of Council and Session, from June 6th, 1678, to July 30th, 1712, 2 vols. (Edinburgh, 1759-61), i, 62-3. 
indicates the survival of the medieval notion that those who had died a violent, untimely death would be condemned to wander until they had been avenged. Overall, although the demonic interpretation of ghosts had become prevalent, it had not completely erased alternative traditions.

\section{Popular Belief and the Dead Body}

If beliefs about ghosts lingered in educated culture, they were likely to be even more persistent in popular culture. After all, printed theological tracts were inaccessible to most of the population. Furthermore, the degree to which people's religious experience actually changed after the Reformation is debatable. Churches were stripped of their Catholic decorations, and services of their ritual elements. Kirk sessions endeavoured to impose strict standards of piety and sexual morality, and educational provision gradually improved, in line with the reformers' aim that everybody should be able to read a copy of the newly-available vernacular Bible. However, these changes were more pronounced in some areas than others. The big towns were the real centres of Protestantism. ${ }^{65}$ Even so, Michael Lynch argues that popular Protestantism enjoyed only gradual growth in most of Scotland's towns. ${ }^{66}$ Change came even more slowly in rural areas. It took time to train new ministers, and there was a shortage of appropriately skilled candidates. In the early 1590 s some 400 parishes were left unfilled. ${ }^{67}$ In many parishes, 'readers' were appointed instead of ministers. Readers could deliver prayers but not preach or administer the sacraments. The reader would frequently be the same individual as had delivered services before the Reformation, making for a certain continuity of experience. ${ }^{68}$

The Gaelic-speaking areas of Scotland were particularly neglected. Reading material was very limited compared to Lowland Scotland: the Book of Common Order was translated in 1567 , but into classical rather than vernacular Gaelic, and there was no

65 Goodare, 'Scotland'; Lynch, 'Preaching to the Converted?'

66 Lynch, 'Preaching to the Converted?', 323.

67 Ibid., 308-9, 302.

68 John McCallum, Reforming the Scottish Parish: The Reformation in Fife, 1560-1640 (Aldershot, 2010), 87. 
Gaelic Bible. A Gaelic catechism was not published until 1653, and a Gaelic psalter not until 1659. Ministers often had to oversee several different parishes, sometimes over large geographical areas. ${ }^{69}$ Under these circumstances, the kirk had little power to start educating people about the unorthodox elements of their belief systems. Julian Goodare argues that 'the church had at best a missionary character up to the nineteenth century, leaving the lively pattern of folk-belief largely undisturbed'. ${ }^{70}$ Certainly, when the minister Robert Kirk (1644-92) and the writer Martin Martin (d. 1719) began investigating popular culture in the Gàidhealtachd, they found plenty of surviving traditions that the kirk would have associated with Catholicism or even paganism. ${ }^{71}$ Even in the Lowlands, the kirk was required to wage an ongoing war against practices such as guising, Yule celebrations, May plays, and midsummer bonfires. $^{72}$ Pilgrimages to healing wells also continued, as did belief in magical charms and amulets. When the Aberdeen synod requested in 1659 that all its ministers should speak against 'charming, heathenish customes in cutting of thee heades of beasts, and carieing off them from one lairds lands to another', it was expressing just the sort of complaint against 'abominable, heathenish superstition' that had been cropping up regularly in kirk session records all over the country. ${ }^{73}$

One significant area in which popular belief persisted regardless of Reformation teachings was death. After the Reformation, the kirk began to strip away many of the ceremonies and rituals associated with death. The First Book of Discipline stated:

For avoiding of all inconveniences we judge it best, that neither singing nor reading be at burial. For albeit things sung and read may admonish some of the living to prepare themselves for death, yet shall some superstitious think that singing and reading of the living may profite the dead. And therefore we think it

69 Geoffrey Parker, 'Success and Failure during the First Century of the Reformation', Past \& Present, cxxxvi (1992), 61; Goodare, 'Scotland', 101.

70 Goodare, 'Scotland', 101.

71 Robert Kirk, 'The Secret Commonwealth of Elves, Fauns \& Fairies', in Michael Hunter (ed.), The Occult Laboratory: Magic, Science, and Second Sight in Late Seventeenth-Century Scotland (Woodbridge, 2001); Martin Martin, A Description of the Western Isles of Scotland (London, 1703), for example 17, 29-30, 49, 85-6, 92-3, 110-13, 117-19, 242, 277-8, 300-35.

72 Lynch, 'Preaching to the Converted?', 323-6; see also Ronald Hutton, The Stations of the Sun: A History of the Ritual Year in Britain (Oxford, 1996).

73 John Stuart (ed.), Selections from the Records of the Kirk Session, Presbytery, and Synod of Aberdeen (Aberdeen, 1846), xxxv; Charles Donald Bentinck, Dornoch Cathedral and Parish (Inverness, 1926), 262. 
most expedient, that the dead be conveyed to the place of buriall with some honest company of the kirk, without either singing or reading; yea without all kind of ceremony heretofore used, other than that the dead be committed to the grave, with such gravity and sobriety, as those that be present may seeme to feare the judgements of God, and to hate sinne which is the cause of death. ${ }^{74}$

The age of elaborate funeral services was, at least in theory, past. ${ }^{75}$ The kirk also tried to clamp down on boisterous lykewakes, or parties traditionally held while watching over the corpse before its burial. ${ }^{76}$ The dead were more cut off from the living than they had been under Catholic theology. As there was no more Purgatory, the living could no longer assist their departed relatives with prayers or masses. Furthermore, the kirk played down the importance of the dead body, despite the fact that the 1560 Confession of Faith declared that the body would rise again at the Last Judgement. ${ }^{77}$ In 1628, religious writer Zacharie Boyd demanded of his readers: 'Is it not your greatest desire to flitte from this bodie which is but a Booth, a shoppe, or Tabernacle of clay'. The kirk rejected the idea that bodies should be buried in consecrated ground; as Boyd explained, 'God will never inquire of a mans Soule where was thy bodie buried' ${ }^{78}$ There were also attempts to put an end to burial within churches, and headstones were viewed with some suspicion. In 1646 the Leith Session refused to allow Christian Robertson to set 'ane hewen stone' at the head of her husband's grave, noting that if they allowed it, 'everie ane wold strive to have ye lyke favor' ${ }^{79}$

However, the kirk's message about the impotency of the dead body was at odds with folk belief. In the absence of substantial source material on popular ghost stories from this period, ideas about the supernatural power of the corpse are worth

74 James K. Cameron (ed.), The First Book of Discipline (Edinburgh, 1972), 200.

75 See Gordon Raeburn, 'The Long Reformation of the Dead in Scotland' (Durham University PhD thesis, 2012).

76 Anne Gordon, Candie for the Foundling (Edinburgh, 1992), 508.

77 Arthur C. Cochrane (ed.), 'The Scottish Confession of Faith, 1560', Reformed Confessions of the Sixteenth Century (Philadelphia, 1966), 184.

78 Zacharie Boyd, The Last Battell of the Soule in Death (Edinburgh, 1628, STC 3446a.5), 84, 1046.

79 On burial see Gordon, Candie for the Foundling, 483; Andrew Spicer, "Defyle Not Christ's Kirk with Your Carrion": Burial and the Development of Burial Aisles in Post-Reformation Scotland', in Bruce Gordon and Peter Marshall (eds.), The Place of the Dead: Death and Remembrance in Late Medieval and Early Modern Europe (Cambridge, 2000). Session quotation from Robertson, South Leith Records, 71. This rule, however, increasingly slipped by the wayside, and by the eighteenth century the Session was regularly granting permission for headstones (71-2). Equally, the rule about church burial was not always upheld; see Spicer, "DDefyle Not Christ's Kirk"”. 
examining. First of all, a dead body was thought to bleed in the presence of its murderer, as Christopher Irvine explained above. This phenomenon was known as 'cruentation', or sometimes by the Scots term, 'bierricht'. George Buchanan offered an early (although historically unsubstantiated) reference to this belief. He wrote that after the murder of King Duff (d. 966/7), the assassins carried the body carefully so that no blood could appear, 'because there is an opinion, received from our ancestors, which as yet obtains among the vulgar, that blood will issue from a dead body many days after the party was murdered, if the murder[er] be present, as if the fact had been but newly committed' ${ }^{80}$ Cruentation cropped up in a diverse range of sources. In versions of the ballad 'Young Hunting' (Child 68), a dead man's wounds bled when his murderer approached, and James VI explained in Daemonologie that a dead body handled by the murderer would 'gush out of bloud, as if the blud wer crying to the heaven for revenge' ${ }^{81}$ Cruentation was also used as evidence in criminal trials. In 1644 Marioun and Swene Peebles were made to handle the bodies of fishermen whom they had allegedly drowned. The bodies bled, 'to the great admiration of the beholders - and revelation of the judgement of the Almytie'. ${ }^{82}$ As we have seen, the baillies and kirk session of South Ronaldsay compelled suspected murderers to handle the corpses; this practice was seen in Aberdeenshire as late as $1698 .^{83}$ In 1688 a Scottish defence counsel objected to the use of the bleeding corpse as evidence in court, when a surgeon swore that after being touched by the accused person the corpse began 'darting out blood through the linnen, from the left side of the neck' ${ }^{84}$

Dead bodies were also frequently used for magical ends. To take evidence from the witch trials, a dead hand was placed in a man's path as part of a spell to kill him; a belt which had been put on a dead child was thought to have healing properties, as was water which had been used to wash human bones; and leaving dead flesh above

80 Buchanan, Rerum Scoticarum Historia, bk. vi, para. 21.

81 Lavater, Of Ghostes and Spirites, 80.

82 Robert Pitcairn (ed.), Criminal Trials in Scotland, 1488-1624, 4 vols. (Edinburgh, 1833), iii, 194.

83 Lizanne Henderson, 'The Survival of Witchcraft Prosecutions and Witch Belief in South-West Scotland', Scottish Historical Review, lxxxv (2006), 57-8. Henderson also includes other examples of the bleeding corpse being used as evidence.

84 Thomas Jones Howell and William Cobbett, A Complete Collection of State Trials and Proceedings for High Treason and Other Crimes and Misdemeanors from the Earliest Period to the Year 1783, 21 vols. (London, 1816), xi, 1402-3. 
the doors of stables was seen as a means of harming cattle or other animals. ${ }^{85}$ The corpses of young men who had died premature deaths were thought to be particularly potent, as we have seen in the writing of Christopher Irvine. ${ }^{86}$ When the corpse was still thought to possess supernatural power, it was no great leap to envisage that it might be able to rise again, in the fashion of the medieval revenant. In 1641 the synod of Fife condemned the practices of carrying the dead about the kirkyard before burial, and of burying unbaptised children separately. ${ }^{87}$ Both of these practices reflected traditional notions of how to prevent the dead from returning. In 1643 the Aberdeen council had to prohibit the use of mort bells, or bells rung while the body was carried to the graveyard and sometimes left at the grave itself; several folklorists have argued that their original purpose was to frighten away evil spirits. ${ }^{88}$ The kirk session of Pencaitland reprimanded a woman in 1651 for putting an iron nail between the corpse and its winding sheet, to prevent the spirit from returning (iron was thought to be a deterrent for ghosts). ${ }^{89}$ The aforementioned ghost stories recorded by Person and the kirk sessions of South Ronaldsay and Leith also indicate the survival of ghost belief. The impact of Protestantism should not, therefore, be over-estimated: it is likely that many elements of ghost folklore survived unscathed over the century following the Reformation.

85 Julian Goodare et al., The Survey of Scottish Witchcraft (University of Edinburgh, 2003), http://www.shca.ed.ac.uk/witches, accessed 1 Aug. 2015. The specific cases referred to are John Smith, Katherine Wilson and Neill John, 1623-30; John Philip, 1631; Isobell Strauthaquhin, 1597; Johnne Brughe, Margaret Kinard and Katherine Mitchell, 1642-3. However, many other examples can be found, for example by searching for 'bone' or 'flesh' used as a ritual object. Unless otherwise specified, all subsequent references to witch trials are taken from the Survey of Scottish Witchcraft.

86 See, for example, the case of Janet Wishart (tried in 1597); she was said to have dismembered the corpse of a recently hanged man. Edward J. Cowan, 'Witch Persecution and Folk Belief in Lowland Scotland: The Devil's Decade', in Julian Goodare, Lauren Martin, and Joyce Miller (eds.), Witchcraft and Belief in Early Modern Scotland (Basingstoke, 2008), 79; Julian Goodare, 'Scottish Witchcraft in Its European Context', in Julian Goodare, Lauren Martin, and Joyce Miller (eds.), Witchcraft and Belief in Early Modern Scotland (Basingstoke, 2008), 49n82.

87 Andrew Edgar, Old Church Life in Scotland: Lectures on Kirk-Session and Presbytery Records (Paisley, 1886), 253.

88 Ibid., 257-8; Gordon, Candie for the Foundling, 496.

89 Lizanne Henderson and Edward J. Cowan, Scottish Fairy Belief: A History (East Linton, 2001), 88. 
The proper interpretation of apparitions was also negotiated through discussions of witches and haunted houses. The Scottish Witchcraft Act was passed in 1563, making witchcraft a capital offence. It was not overturned until 1736. In the interim, at least 3,837 people were accused of witchcraft, of whom about 84 percent were women. There were particularly marked periods of persecution in 1590-1, 1597, 1628-30, 1649 and 1661-2. Execution rates are difficult to establish, as few cases record the sentence passed, but may have been in the region of about two thirds. ${ }^{90}$ As such, Scotland experienced relatively severe witch-hunting, executing as many as ten times more witches per head of the population than England, and five times the European average..$^{11}$ In her 1986 article Ghost and Witch in the Sixteenth and Seventeenth Centuries, Gillian Bennett argues that the two subjects - ghosts and witches - should be considered together. She suggests that re-defining ghosts as demonic beings may have encouraged the idea that society was under attack by the legions of Hell, and so intensified the witch hunts. She also emphasises the crossovers between witches and ghosts, declaring that the two "were so closely allied that for over a hundred years they constituted virtually a single subject'. ${ }^{92}$ Witches and ghosts, she notes, were linked to similar folkloric traditions - both were associated with the dead body and with necromancy. McKeever similarly argues that, at least in England, ghosts were absorbed into the witchcraft discourse; traditional ghost stories more or less disappeared, and apparitions were interpreted as demons conjured up by witches. ${ }^{93}$

On one hand, it can be argued that witch beliefs complemented ghost traditions, rather than absorbing them. Stories about the activities of witches reinforced the notions of the powerful corpse described above. As we have seen, witches made use

90 Julian Goodare et al., 'Introduction to Scottish Witchcraft', The Survey of Scottish Witchcraft (University of Edinburgh, 2003), http://www.shca.ed.ac.uk/Research/witches/introduction.html, accessed 1 Aug. 2015.

91 James Sharpe, 'Witch-Hunting and Witch Historiography: Some Anglo-Scottish Comparisons', in Julian Goodare (ed.), The Scottish Witch-Hunt in Context (Manchester, 2002), 182; Julian Goodare, 'Witchcraft in Scotland', in Brian P. Levack (ed.), The Oxford Handbook of Witchcraft in Early Modern Europe and Colonial America (Oxford, 2013), 302.

92 Gillian Bennett, 'Ghost and Witch in the Sixteenth and Seventeenth Centuries', Folklore, xcvii (1986), 9, 3.

93 McKeever, 'Ghost in Early Modern Protestant Culture', 136-46. 
of dead body parts in magical rituals. An account of a woman called Isobel Keir reviving a dead man at his lykewake may have been intended to underline the character of witches as necromancers, but it also suggested that the corpse retained some potency. ${ }^{94}$ Furthermore, witches were thought to have dealings with ghosts. Jonet Reid was able to advise a man called Robert Sinclair on how to rid himself of 'apparitiounes of his ffirst wyiff, which wexit him and disquietit him verie much'. ${ }^{95}$ Margaret Lang, tried in 1697, was a sort of medium who could contact people's dead relatives. Bessie Dunlop (tried in 1576), Alison Pearson (tried in 1588) and Elspeth Reoch (tried in 1616) all had spectral advisers who were said to be dead men (Thom Reid, William Symsone and Johne Stewart respectively). ${ }^{96}$ Ghosts and witches also attended the same parties. Margaret Bell (tried in 1649) met the Devil in a quarry; he was accompanied by a group of people who had died of the plague. Andro Man (tried in 1597-8) claimed to have encountered the ghosts of James IV and Thomas the Rhymer at a fairy gathering. Margaret Alexander (tried in 1647) attended meetings between fairies and witches, some of whom she recognised as deceased acquaintances. However, even when apparitions were described as returning dead people, they frequently still carried demonic connotations. This can be seen in the case of the ghostly advisers who visited Bessie, Alison and Elspeth. Thom Reid urged Bessie to renounce Christianity, while William Symsone was interpreted as an 'evil spirit' and Johne Stewart as a 'devell' by the interrogators. ${ }^{97}$

Witches could also become apparitions themselves. Margaret Hutchison, tried in 1661, was said to have appeared several times in a house in apparition form, and finally to have suffocated a baby there. Other witches appeared as animals: in the same year, Beatrix Leslie was accused of taking the form of an apparition cat to attack some neighbours with whom she had quarrelled. James VI discussed the idea of witches appearing as beasts. He denied that there was any actual physical

94 Julian Goodare, 'Women and the Witch-Hunt in Scotland', Social History, xxiii (1998), 296-7.

95 G. F. Black, County Folklore III: Examples of Printed Folklore Concerning the Orkney and Shetland Islands, ed. Northcote W. Thomas (London, 1903), 101.

96 Henderson and Cowan, Scottish Fairy Belief, 60; Emma Wilby, Cunning Folk and Familiar Spirits: Shamanistic Visionary Traditions in Early Modern British Witchcraft and Magic (Brighton, 2005), 18, 56.

97 Wilby, Cunning Folk and Familiar Spirits, 91. 
transformation, but posited that the Devil could make witches appear in different guises. ${ }^{98}$ George Mackenzie presented a similar interpretation in 1678 :

if we consider the strange tricks of Juglers, and the strange apparitions that Kercher and others relate from natural causes, we may believe that the Devil may make a woman appear to be a beast, \& è contra, by either abusing the sense of the beholders, or altering the Medium, by inclosing them in the skin of the beast represented, or by inclosing them in a body of air, shap'd like that which he would have them represent, ${ }^{99}$

In this context, ghosts were more at risk of being simply absorbed into witcheraft discourses. In the medieval period, this type of apparition might be interpreted as a ghost, as souls were known to appear in animal forms. ${ }^{100}$ In the wake of the Reformation it was much more likely to be explained in demonic terms.

The argument about ghost and witch discourses blending together has also been applied to poltergeists, a relatively common supernatural bugbear. Poltergeists ranged from being minor irritants (one simply 'bickered' with the minister he was haunting) to dangerous adversaries who could beat children black and blue, or set houses on fire. ${ }^{101}$ They might tear clothes, throw items around, make mysterious noises, put pins in food, or attempt to ruin Bibles. Peter Maxwell-Stuart argues that poltergeists were generally thought of as spirits of the dead in the medieval period, and again in the eighteenth century. In between, they were primarily seen as spirits conjured up by witches. ${ }^{102}$ There was certainly an association between witches and poltergeists in early modern Scotland. James VI explained that witches had the power to 'make spirites either to follow and trouble persones, or haunt certaine houses, and affraie oftentimes the inhabitantes'. He also involved the Devil, noting that 'when [the Devil] troubles certaine houses that are dwelt in, it is a sure token either of grosse ignorance, or of some grosse and slanderous sinnes amongst the

98 James VI, 'Daemonologie', bk. ii, ch. iv, 28.

99 Mackenzie, Laws and Customes of Scotland, 100.

100 For a (somewhat ambiguous) Scottish example see Maxwell, Chronicle of Lanercost, 4-5.

101 Francis Grose, The Antiquities of Scotland, 2 vols. (London, 1797), 192.

102 P. G. Maxwell-Stuart, Poltergeists: A History of Violent Ghostly Phenomena (Stroud, 2011), 96, 132. 
inhabitantes thereof: which God by that extraordinarie rod punishes' ${ }^{103}$ In 1644 the Presbytery of Strathbogie suspected witchcraft in the case of 'clodding and fearfull trouble' experienced by a household. ${ }^{104}$ The most common means of ending the haunting of a house was not by talking with the offending spirit and performing some service for it, but rather through a sort of exorcism, conducted by ministers through prayer and Scripture readings. In 1670, William Annand noted that 'if our houses be haunted, by evil spirits', the proper way to be delivered was through 'courage, and faith ... and a goodly life, fasting, prayer'. ${ }^{105}$ Even John Knox was said to have dispossessed an evil spirit from a house in this fashion. ${ }^{106}$

The best-known poltergeist from this period was probably the demon of Glenluce in Galloway, which haunted a house for a few years from 1654. Robert Baillie, Professor of Divinity at Glasgow, wrote in 1661 that it was 'notourlie known'. It was also described as famous by Robert Kirk in the mid-1670s, and was discussed at length by George Sinclair, both in his Hydrostaticks (1672) and Satan's Invisible World Discovered (1685). ${ }^{107}$ This poltergeist haunted the family of a weaver - John Campbell in Baillie's version, Gilbert Campbell in Sinclair's. In Baillie's version it threw stones, set fire to the house, and cut the webs in the looms, but without ever doing serious harm. Many ministers came to pray and fast in the house, and one had long conversations with the offender. A beggar often lodged in the house, but was subsequently hanged at Dumfries for atheism. Around the time of his death the poltergeist became subdued, but later resumed its agitations. For a year at the time of writing it had fallen quiet. Baillie clarified his own interpretation of this story with the closing observation that 'there is much witcherie up and downe our land'. ${ }^{108}$

103 James VI, 'Daemonologie', bk. ii, ch. v, 33; bk. iii, ch. i, 40.

104 John Stuart (ed.), Extracts from the Presbytery Book of Strathbogie, A.D. 1631-1654 (Aberdeen, 1843), 50-1.

105 William Annand, Pater Noster, Our Father, Or, The Lord's Prayer Explained the Sense Thereof and Duties Therein from Scripture, History, and Fathers (Edinburgh, 1670), 449.

106 John Livingstone, 'Memorable Characteristics, and Remarkable Passages of Divine Providence', in W. K. Tweedie (ed.), Select Biographies, 2 vols. (Edinburgh, 1845), i, 295.

107 Michael Hunter, 'Introduction', in Michael Hunter (ed.), The Occult Laboratory: Magic, Science, and Second Sight in Late Seventeenth-Century Scotland (Woodbridge, 2001), 16; George Sinclair, The Hydrostaticks, Or, The Weight, Force, and Pressure of Fluid Bodies, Made Evident by Physical, and Sensible Experiments (Edinburgh, 1672), 239-47; Sinclair, Satan's Invisible World Discovered, 56-67.

108 Robert Baillie, Letters and Journals of Robert Baillie, A. M., ed. David Laing, 3 vols. (Edinburgh, 1841-2), iii, 436. 
Sinclair's version of the story was similar, but placed the blame more squarely at the door of the blasphemous beggar. ${ }^{109}$ The disturbances began after the family refused this beggar alms. He threatened to hurt the family, and was later hanged. This would have been a recognisable witchcraft pattern for early modern folk: beggars were often suspected of turning to dark arts if their requests were refused. ${ }^{110}$

John Maitland, first Duke of Lauderdale, relayed a few stories of haunted houses to Richard Baxter in 1659. One came from near Edinburgh and concerned a man and his son, both ministers. Their house was 'extraordinarily troubled with noises'; locks would fly open and their clothes would be strewn about. Once they rose to find their bed linen spread across the table, along with used napkins and cups still containing traces of liquor. The persistent noise would subside to a 'gentle knocking' when the family prayed, but would become excessive again as soon as they stopped. They never heard a voice or saw an apparition. However, one night a maid took to bed half a cannonball, kept for breaking coals. She told a fellow servant that 'if the Devil troubled them that Night, she would brain him'. When she was awoken by the usual strange noises she threw the cannonball, which vanished, never to be seen again. Lauderdale also provided a story from Annandale in Dumfries, concerning a gentleman called Johnston. Johnston's house had been haunted for some fifty or sixty years. He had heard drums and trumpets before the outbreak of the last war, and some English soldiers quartering in the house had been beaten by the poltergeist. ${ }^{111}$ These cases were not tied to witches, but nor were they associated with ghosts. In the former, the diabolic nature of the poltergeist was strongly implied. The latter presented a more ambiguous poltergeist - prophetic, and apparently a Scottish nationalist. However, its violence suggested that it, too, was demonic in nature.

Poltergeists, in summary, were usually identified as demons. Nonetheless, the

109 See pp. 64-5 for more on Sinclair's interpretation of this story.

110 On this pattern in England especially see Alan Macfarlane, Witchcraft in Tudor and Stuart England: A Regional and Comparative Study (London, 1970), 172-6, 196-8, 206; Keith Thomas, Religion and the Decline of Magic: Studies in Popular Beliefs in Sixteenth and Seventeenth Century England (London, 1971), ch. 17; Robin Briggs, Witches and Neighbours: The Social and Cultural Context of European Witchcraft, 2nd edn (Oxford, 2002), 118-23.

111 Richard Baxter, The Certainty of the World of Spirits, and Consequently, of the Immortality of Souls of the Malice and Misery of the Devils and the Damned (London, 1691), 82-92. 
medieval association between poltergeists and the spirits of the dead had not completely disappeared, especially within popular culture. When the earl of Huntly died in 1562, reports circulated afterwards of disturbances in his house. Strange noises were heard, and people fell mysteriously ill. This led one of the men of his house to fear that 'the brute wald pas through the cuntrey that the erle of Huntley wer risen againe'. ${ }^{112}$ It is possible that Huntly was more likely to be associated with this kind of quasi-demonic activity because he was a Catholic and had died as an enemy of the state (his body was convicted of treason in 1563), but there was no explicit suggestion that demons were involved. ${ }^{113}$ In his The Secret Commonwealth of Elves, Fauns and Fairies, written in the early 1690s, Robert Kirk noted:

[The Mountain People] affirm those Creatures that move invisibly in a House, and cast huge $<$ great $>$ Stones ... to be Souls that have not atteaned their Rest, thorough a vehement desyre of revealing a murther or notable injury don or receav'd, or a Treasure that was forgot in their Lyftime on Earth, which when disclos'd to a Conjuror alon the Ghost quite removes. ${ }^{114}$

George Sinclair told a story, apparently from 1635, of a hanged man who was not pardoned despite a miraculous resurrection; he went on to haunt his own house. ${ }^{115}$

Overall, witches and ghosts were not fully assimilated into a single subject, especially within popular culture. Some strands of witch belief could reinforce a belief in the returning dead, and stories of cooperation between witches and ghosts allowed ghosts a distinct identity. All supernatural creatures overlapped to an extent, and attempts to pick them apart can easily become anachronistic. Within popular culture, it is unlikely that the demonic ghost and the traditional returning dead person were taken to be mutually exclusive, and witches were probably at liberty to cooperate with either or both. Furthermore, there is evidence that a tentative connection remained between poltergeists and the dead. When it came to elite

112 Richard Bannatyne, Memorials of Transactions in Scotland, 1569-1573, ed. Robert Pitcairn (Edinburgh, 1836), 336-8 (quotation 337).

113 See Allan White, 'Gordon, George, Fourth Earl of Huntly (1513-1562)', Oxford DNB (Oxford University Press, 2004), http://www.oxforddnb.com/view/article/11034, accessed 1 Aug. 2015.

114 Kirk, 'Secret Commonwealth', 85. Hunter's use of angle brackets for '<great $>$ ' indicates that the word was inserted above the line in the original.

115 Sinclair, Satan's Invisible World Discovered, 127. 
interpretations, however, the demonic theme was definitely dominant. Apparitions were taken to be demons, or witches disguised by the Devil; haunted houses were also tied to demonic agency, whether a witch was involved or not. If ghost beliefs were not completely eclipsed by witch discourses, they were certainly overshadowed.

\section{Seventeenth-Century Providentialism}

After the Reformation and the widespread adoption of the demonic theory of apparitions, the place of ghosts in Scottish society did not undergo any major changes until the late seventeenth and eighteenth centuries. However, there was (arguably) a gradual change in perceptions of the supernatural, which may have had some impact on apparition beliefs. Both general and special providence became increasingly fashionable concepts in the late sixteenth and seventeenth centuries. General providence was God's overarching plan for the universe, as drawn up at the Creation. In England, as Ronald J. VanderMolen has shown, religious groups increasingly made use of the concept of God's providence in the late sixteenth and early seventeenth centuries. George Hakewill painted a picture of the English church and society as having been blessed and upheld by God throughout history. Thomas Beard's 1597 Theatre of Gods Judgements demystified the historical process, taking past events as a clear revelation of God's purpose. ${ }^{116}$ In Scotland, John Knox likewise initiated a form of history-writing that sought to unravel God's will, using providence as a propaganda tool. ${ }^{117}$

Special providences, by most authors' definitions, were God's spontaneous acts of intervention in the universe. ${ }^{118} \mathrm{~A}$ wide range of events could fall under the heading, from monstrous births to comets to showers of blood, from a minister finding a

116 Ronald J. VanderMolen, 'Providence as Mystery, Providence as Revelation: Puritan and Anglican Modifications of John Calvin's Doctrine of Providence', Church History, xlvii (1978), $27-47$.

117 Richard Kyle, 'John Knox's Concept of Divine Providence and Its Influence on His Thought', Albion, xviii (1986), 395-410. See also the essays in Roger Mason (ed.), John Knox and the British Reformations (Aldershot, 1998).

118 Alexandra Walsham, Providence in Early Modern England (Oxford, 1999), 12. 
spider in his porridge to the apparition of a battle in the sky. ${ }^{119}$ Perhaps the broadest interpretation came from Renfrewshire minister Ninian Campbell, who explained in 1635 that 'by his speciall providence' God had 'an extreame fatherly regard to us'; without it, Campbell wrote, 'one hair cannot fall out of our head, one cubit cannot be added to our stature ... a little sparrow cannot fall to the ground'. ${ }^{120}$ Special providences were a more contentious topic than general providence. Certain thinkers rejected their existence altogether; there was also debate about the extent of their power. ${ }^{121}$ Nonetheless, pamphlets or collections detailing special providences proliferated in the seventeenth century. In England the numbers soared during the Civil War (1642-6), as they were used for political propaganda. Scotland's publishing industry was more modest, but pamphlets detailing providences appeared regularly from the mid-seventeenth century. ${ }^{122}$

Providences found a comfortable place within the religious culture of seventeenthcentury Scotland. It was commonly believed that God communicated with the elect through providences, and that it was the duty of a Protestant to note these divine messages. ${ }^{123}$ The Covenanting movement swept Scotland in the 1630s. Scots were urged to pledge their allegiance to the National Covenant, demanding a Presbyterian kirk free from monarchical interference. Personal covenanting with God was also encouraged; the Covenanters placed emphasis on introspection and a spiritual conversion experience. Spiritual journals blossomed within this religious climate, and provided a vehicle for Covenanters to explore marks of God's favour. James Mitchell of Dykes in Ardrossan, reflecting on the period from the 1620s to the 1640s, cited 'many singular instances of Divine Providence', including 'that my two years accounts crop 1643. and 1644. with my lord Montgomerie are fitted and subscribed withoyt any debat or contest betwixt his Lordship and me, which I did readily expect in some particulars as anent the six baggage horse ... and fourteen bolls meal of

119 Ibid., 20.

120 Ninian Campbell, A Treatise upon Death (Edinburgh, 1635, STC 4533), sec. 'The assertion, It is appointed, \&c.'

121 Walsham, Providence, 218-31; William E. Burns, An Age of Wonders: Prodigies, Politics, and Providence in England, 1657-1727 (Manchester, 2002), 19-26, 57-96.

122 Jane Ridder-Patrick, 'Astrology in Early Modern Scotland, ca.1560-1726' (University of Edinburgh PhD thesis, 2012), 99-126, 324-30.

123 Thomas, Religion and the Decline of Magic, 108. 
indrink in the girnil'. ${ }^{124}$ Mitchell's account of divine intervention might be rather mundane, but more dramatic stories also abounded. Covenanting ministers were said to prophesy and heal the sick. One, John Welch, even raised a dead man through his prayers, in an interesting parallel with the accused witch Isobel Keir. ${ }^{125}$

With the 1660 Restoration, Episcopacy was re-established in Scotland. Around a quarter of ministers refused to conform to the new religious settlement. ${ }^{126}$ In the following decades the government alternated between clamping down on the rebellious Presbyterians and granting indulgences, which allowed evicted ministers to return to their parishes if they agreed to keep the peace. Presbyterianism was not officially reinstated until 1690, after James VII was deposed in favour of his daughter Mary and her husband William of Orange. Within this context there was a clear motivation for the deposed Presbyterians to look for proofs of God's favour. Spiritual diaries further proliferated, and providences were collated and published. ${ }^{127}$ Notable examples include John Livingstone's Memorable Characteristics, and Remarkable Passages of Divine Providence, Exemplified in the Lives of Some of the Most Eminent Ministers and Professors in the Church of Scotland (written in 1668); Robert Fleming's The Fulfilling of the Scripture, or, An Essay Shewing the Exact Accomplishment of the Word of God in his Works of Providence, Performed \& to be Performed (1671); and Robert Law's Memorialls: Or, The Memorable Things that Fell Out Within this Island of Brittain from 1638 to 1684. Special providences became such an ingrained feature of Presbyterian religious culture that ministers continued to collect them even after Presbyterianism had been reinstated. The minister Robert Wodrow began recording providences in 1701 and continued until his death in 1734, while the radical Patrick Walker amassed stories of Covenanting ministers in the late 1720 s and early 1730 s (they were eventually published together

124 James Mitchell, Memoirs of the Life of James Mitchell of Dykes, in the Parish of Ardrossan (Glasgow, 1759), 69-72, 70. 'Fourteen bolls meal of indrink' meant 'fourteen bolls of meal short'; a girnil was a barrel or chest.

125 Margo Todd, The Culture of Protestantism in Early Modern Scotland (New Haven, 2002), 394-9 (Welch on 397). See also Louise Yeoman, “"Away with the Fairies”, in Lizanne Henderson (ed.), Fantastical Imaginations: The Supernatural in Scottish History and Culture (Edinburgh, 2009).

126 Stewart J. Brown, 'Religion and Society to c.1900', in T. M Devine and Jenny Wormald (eds.), The Oxford Handbook of Modern Scottish History (Oxford, 2012), 84.

127 David George Mullan, Narratives of the Religious Self in Early-Modern Scotland (Aldershot, 2010), 42 . 
as Six Saints of the Covenant in 1901). ${ }^{128}$

For all their interest in special providences, most of these men would probably have taken James VI's view on ghosts (Wodrow, as we shall see, was an exception). Robert Fleming spoke of how wicked spirits appeared frequently, but described 'apparitions of the dead ... delivered out of purgatory' as a 'blind superstition'. ${ }^{129}$ The Presbyterian minister Robert Blair (1593-1666) stayed in an allegedly haunted room and saw an apparition, but refused to be frightened by it. He explained that the whole was God's mission to teach him to pray fervently, and to demonstrate through the apparition's impotency 'that devils were chained with chains of darkness, reserved to the judgment of the last day'. ${ }^{130}$ Nevertheless, there was crossover between special providences and ghosts. Stories of special providences often featured apparitions. The minister Alexander Stirling saw a group singing a psalm, accompanied by a white horse with a blood-red saddle; the whole party subsequently vanished. Archibald Gillespie saw two pointed clouds attacking a woman in the sky until her dress tore and blood rained down, and Robert Law recounted a tale of an apparition in the form of 'a man sett on a whyt horse ... with his eyes lyke flammes of fyre'. ${ }^{131}$

Furthermore, stories of ghostly armies enacting airborne fights were popular: at least a dozen separate accounts survive from the late seventeenth and early eighteenth centuries. Sometimes these battles foreshadowed genuine battles. At other times they followed them, a sort of spectral echo. While these apparitions were not necessarily ghosts, there was a link to the dead. Ghostly battles in the air were popular in Greek and Roman times. They were associated with notions of souls battling on their way to the land of the dead, and were perhaps related to medieval tales of the 'Wild Hunt'. ${ }^{132}$ Years of warfare encouraged the re-emergence of stories of this sort, and

128 Wodrow is discussed at length on pp. 68-75.

129 Robert Fleming, The Fulfilling of the Scripture, in Three Parts, reprint of 1681 3rd edn, 2 vols. (Glasgow, 1801), ii, 57, 238.

130 Robert Blair, The Life of Mr. Robert Blair, ed. T. M'Crie (Edinburgh, 1848), 8.

131 Patrick Walker, Six Saints of the Covenant, ed. David Hay Fleming, 2 vols (London, 1901), i, 35; Robert Wodrow, The Correspondence of the Rev. Robert Wodrow, ed. Thomas M'Crie, 3 vols. (Edinburgh, 1842-3), i, 561-2; Robert Law, Memorialls: Or the Memorable Things That Fell out Within This Island of Brittain from 1638 to 1684, ed. Charles Kirkpatrick Sharpe (Edinburgh, 1818), 162.

132 Lavater, Of Ghostes and Spirites, 81; Schmitt, Ghosts in the Middle Ages, 93-122. 
they circulated more easily as the printing industry developed. Frederick Valletta notes that there was a surge of English stories about ghostly battles after the Civil War, and argues that this was linked to a contemporary fear that the ghosts of soldiers were returning, having not had proper burials. ${ }^{133}$ The Scottish ministers collecting and publishing stories of ghostly battles may not have been presenting them as accounts of the returning dead, but the stories might nonetheless have stemmed from ghost beliefs, and might have been read as such by sections of their audience. The interest in special providences hinted at the possibility that ghosts, too, might be transformed into divine messengers.

\section{Conclusion}

In medieval Scotland, the dead could return to make moral or religious points, or because some residual life-force lingered in the corpse. At least in theory, this changed after the Reformation, in line with broader European patterns. James VI was one of the most powerful critics of ghosts, and Scottish theologians generally seem to have fallen into step with him, redefining ghosts as demons (that may or may not have been summoned by witches). However, it is important not to over-simplify this picture. Although ghosts were accepted by many theologians prior to the Reformation, this is not to say that scepticism was not already present in society: recall Gavin Douglas's concern that people would scorn the 'vayn superstitionys aganyst our richt beleve'. Many Catholics may not have believed in ghosts, and many Protestants may have continued to do so in spite of James's arguments. Ghost stories did still occasionally crop up in the work of educated men, or in kirk session records. James was probably rather over-optimistic when he declared: 'For as we know, moe Ghostes and spirites were seene, nor tongue can tell, in the time of blinde Papistrie in these Countries, where now by the contrarie, a man shall scarcely all his time here once of such things'. ${ }^{134}$

133 Frederick Valletta, Witchcraft, Magic and Superstition in England, 1640-1670 (Aldershot, 2004), $81-2$.

134 James VI, 'Daemonologie', bk. ii, ch. vii, 37. 
No real effort was made to educate people regarding the unorthodoxy of ghosts. The kirk was hampered by the difficulty of ensuring suitable religious provision throughout the country, and the Gaelic-speaking areas in particular were neglected. Although kirk sessions did criticise and punish superstitious practices, there is little evidence that they triumphed; plenty of 'heathenish' charming was still going on by the eighteenth and nineteenth centuries. ${ }^{135}$ The notion of the supernatural power of the corpse also survived, reinforcing medieval revenant beliefs. The witch hunts were an area where popular and elite culture met, and it does seem that the demonic notion of ghosts had some impact there. Apparitions were frequently classed as witches rather than as ghosts, and poltergeists were usually associated with witches and demons rather than with dead people. However, several aspects of the witch discourse complemented traditional ghost belief. Accounts of witches and their practices often emphasised the potency of the corpse. Witches also had dealings with the spirits of dead people. Overall, although ghosts and witches were closely linked, it is probably best to avoid converting them into a 'single subject'. James VI would have been delighted to see witches and demonic spirits utterly absorbing all other supernatural beings, but the ghost probably did retain a distinct identity, insofar as any supernatural being can be called distinct given the intertwined nature of folk beliefs. Witches became dominant in the supernatural world, but ghosts lingered on, and stand as a reminder that we should hesitate to view the Scottish Reformation as an unmitigated success story.

It is also possible that the climate was becoming gradually more amenable to ghosts as time went by. In the mid seventeenth century the Covenanters' emphasis on a spiritual journey and communion with God, combined with the surge of accounts of special providences coming from war-stricken England, reinvigorated the idea of God intervening directly in the world. Accounts of apparitions could circulate more freely. Stories of ghostly armies were most obviously related to ghost legends, and may have both drawn on and encouraged notions of souls lingering after death. Interest in special providences laid the groundwork for the late seventeenth- and

135 Numerous accounts of superstitious practices can be found in the Statistical Accounts of 1791-9 and 1834-45. The Statistical Accounts of Scotland, 1791-1845 (University of Glasgow, University of Edinburgh), http://edina.ac.uk/stat-acc-scot, accessed 1 Aug. 2015. 
eighteenth-century trend towards reclaiming ghosts as religious servants, which will be explored in the next chapter. Having said that, in closing it is worth underlining the fact that, although ghost beliefs were not wiped out, surviving stories from this period are few and far between. In the medieval period ghosts did not have an uncontested place within religious culture, and matters worsened after the Reformation. Ghosts were certainly a familiar concept, but they were not the hugely popular and dominant supernatural tradition that they would arguably become. Ghosts did survive, and apparitions in general may have gradually become a more acceptable facet of religious culture. Broadly speaking, however, the climate from 1560 to the latter decades of the seventeenth century remained hostile. Scotland's haunted reputation had yet to be formed. 


\section{Chapter Two}

\section{Religious Ghosts}

In the late seventeenth century, Scottish ghost stories proliferated. Amidst the philosophical developments of the Scientific Revolution and early Enlightenment, there was a growing fear of deism and atheism. In England this prompted a range of figures to re-integrate ghosts and other supernatural beings into the Protestant framework, as a way of demonstrating the reality of the soul and the afterlife. This trend was also seen in Scotland, albeit on a smaller scale. The natural philosopher George Sinclair (d. 1696) and minister Robert Wodrow (1679-1734) both collected ghost stories, and ghosts were sporadically revived to make religious or moral points over the course of the eighteenth century. This chapter will analyse the ways in which ghosts were converted into Protestant servants, and consider how well they fitted the role. The chronological focus is predominantly on the late seventeenth and early eighteenth centuries, but the chapter will also discuss how religious ghosts fared as the eighteenth century proceeded.

\section{I 'That prevailing Spirit of Atheism and Infidelity'}

The quotation above is taken from $A$ True Relation of an Apparition (1696), a pamphlet by the minister Alexander Telfair. Telfair explained that he was writing for 'the Conviction and Confutation of that prevailing Spirit of Atheism and Infidelity in our time: denying both in Opinion and Practice the Existence of Spirits, either of God or Devils; and consequently a Heaven and Hell'. ${ }^{1}$ The idea that stories of hauntings might be used in this way will be discussed presently. Firstly, it is worth surveying this 'Spirit of Atheism' that concerned Telfair. This is made more complex by issues surrounding terminology. Telfair seems to have defined 'atheists' in a modern sense, as those who did not believe in a God. This was by no means a uniform approach. As Michael Hunter and David Wootton observe, 'orthodox contemporaries were prone

1 Alexander Telfair, A True Relation of an Apparition, Expressions and Actings, of a Spirit (Edinburgh, 1696), 3. 
to conflate with "atheism" a range of positions that appeared to them to militate towards it, particularly deistic formulations of religious belief that played down the role of revelation and an active personal deity'. ${ }^{2}$ When I refer to a contemporary 'fear of atheism', this should be understood broadly, as a fear of philosophical outlooks that devalued the importance of spiritual entities, the afterlife, divine providence and miracles.

The notion that society was battling a rising tide of atheism was spurred by the significant philosophical developments of the late seventeenth century. The controversial work of René Descartes (1596-1650) became dominant within universities in most Protestant countries, including Scotland. ${ }^{3}$ Descartes argued for a mechanistic universe, created by God but left to function according to simple mathematical laws. Many of his opponents were uncomfortable with the notion of a God who did not directly govern on a day-to-day basis. Descartes was also criticised for emphasising scientific observation rather than Scripture as a means of explaining the universe, while his dualistic system of mind and matter was thought to undervalue spiritual entities. ${ }^{4}$ Even more contentious than Descartes was Baruch Spinoza (1632-77). Spinoza argued that everything was composed of a single substance. God did not alter the universe; he was the universe. No event could transcend the laws of nature, as God and nature were indistinguishable. Miracles were therefore impossible. Spinoza also rejected the existence of demons. He was lambasted from all sides, and Jonathan I. Israel argues that he became the 'symbolic

2 Michael Hunter and David Wootton, 'Introduction', in Michael Hunter and David Wootton (eds.), Atheism from the Reformation to the Enlightenment (Oxford, 1992), 2. See also Michael Hunter, 'The Problem of "Atheism" in Early Modern England', Transactions of the Royal Historical Society, xxxv (1985), 135-57; David Wootton, 'New Histories of Atheism', in Michael Hunter and David Wootton (eds.), Atheism from the Reformation to the Enlightenment (Oxford, 1992); Nigel Smith, 'The Charge of Atheism and the Language of Radical Speculation, 1640-1660', in Michael Hunter and David Wootton (eds.), Atheism from the Reformation to the Enlightenment (Oxford, 1992).

3 Jonathan I. Israel, Radical Enlightenment: Philosophy and the Making of Modernity, 1650-1750 (Oxford, 2001), 23-42; Michael Wasser, 'The Mechanical World-View and the Decline of WitchBeliefs in Scotland', in Julian Goodare, Lauren Martin, and Joyce Miller (eds.), Witchcraft and Belief in Early Modern Scotland (Basingstoke, 2008), 216; Christine M. Shepherd, 'Philosophy and Science in the Arts Curriculum of the Scottish Universities in the 17th Century' (University of Edinburgh PhD thesis, 1975), esp. 61-165; Alasdair Raffe, 'Intellectual Change before the Enlightenment: Scotland, the Netherlands and the Reception of Cartesian Thought, 1650-1700', Scottish Historical Review, xciv (2015), 27, 45-6.

4 Israel, Radical Enlightenment, 28. 
head of philosophical deism and atheism in Britain and Ireland, as well as on the continent'.5

Similarly controversial ideas emerged from England. Both Thomas Hobbes (15881679) and John Locke (1632-1704) were criticised for placing a dangerous emphasis on the role of reason, rather than revelation, within religion. Although neither went so far as Spinoza in denying the existence of miracles, both suggested that testimony should be taken with caution. ${ }^{6}$ There was also a handful of English figures commonly termed deists. There has been much debate over how this term should be defined, and to what extent it is possible to speak of a 'deist movement' when the men associated with it were few in number and diverse in their ideas. ${ }^{7}$ However, those thinkers associated with deism generally held that religion should be subject to the dictates of reason, and tended to take a sceptical position on miracles. Charles Blount, John Toland, Thomas Woolston and Matthew Tindal were among those late seventeenthand early eighteenth-century figures who argued for a natural religion, emphasising reason at the expense of revelation. ${ }^{8}$

The extent to which these philosophers posed a genuine threat to late-seventeenth and early-eighteenth century religious culture is debatable. Israel underlines the importance of the rise of secularisation and rationalisation. He argues that 'In England a veritable sea-change had taken place by the early eighteenth century', and quotes Keith Thomas: 'The triumph of the mechanical philosophy meant the end of the animistic conception of the universe which had constituted the basic rationale for magical thinking'. ${ }^{9}$ On the other hand, the monster of atheism was part myth. S. J. Barnett argues that the deist challenge was much exaggerated, and could never really endanger the church. Even Israel concedes that the foremost thinkers of the late

5 Ibid., 603.

6 See Patricia Springborg, 'Hobbes on Religion', in Tom Sorell (ed.), The Cambridge Companion to Hobbes (Cambridge, 1996); Nicholas Wolterstorff, 'Locke's Philosophy of Religion', in Vere Chappell (ed.), Cambridge Companion to Locke (Cambridge, 1994).

7 S. J. Barnett, The Enlightenment and Religion: The Myths of Modernity (Manchester, 2003).

8 See Jeffrey R. Wigelsworth, Deism in Enlightenment England: Theology, Politics, and Newtonian Public Science (Manchester, 2009).

9 Israel, Radical Enlightenment, 7; Keith Thomas, Religion and the Decline of Magic: Studies in Popular Beliefs in Sixteenth and Seventeenth Century England (London, 1971), 664. 
seventeenth and early eighteenth centuries tried to fit scientific and mathematical developments into a Christian framework, with emphasis on the authority of Scripture (he excepts Spinoza from this picture, and also - disputably - Pierre Bayle). ${ }^{10}$ The reality of miracles, providence, the soul and the afterlife was still beyond question for the vast majority of philosophers. Nevertheless, however flimsy the evidence may have been, there was a popular perception that the core tenets of Christianity were under threat. Within this context, some authors began to look for new ways to defend religious values.

\section{Rehabilitating Ghosts}

Several historians have argued that England saw a 'conscious and sustained reintegration of ghosts into Protestant theology' in the late seventeenth century. ${ }^{11}$ Multiple works were produced collating 'true' stories about ghosts (usually alongside other creatures, such as witches). Henry More's 1652 An Antidote Against Atheisme was the first of this genre. It was followed by a host of similar works, most famously by Joesph Glanvill (Sadducismus Triumphatus, 1681), Richard Bovet (Pandaemonium, 1684), and Richard Baxter (The Certainty of the World of Spirits, 1691). John Aubrey collected folklore, while Samuel Wesley co-edited The Athenian Mercury (1691-7), which devoted itself to 'curious questions' and frequently reported and discussed ghost stories. ${ }^{12}$ Jo Bath and John Newton argue that the Reformation saw ghost belief divided along strict confessional lines, but 'by the end of the seventeenth century, this surety seems to have become radically altered, such that belief in ghosts as something other than devils in human shape was entirely respectable among committed Protestants'. Indeed, they add that the demonic interpretation of ghosts fell by the wayside, being largely replaced by the idea that ghosts were indeed the returning dead. ${ }^{13}$

10 Barnett, Enlightenment and Religion, 11-129; Israel, Radical Enlightenment, 15.

11 Sasha Handley, 'Reclaiming Ghosts in 1690s England', in Kate Cooper and Jeremy Gregory (eds.), Signs, Wonders, Miracles: Representations of Divine Power in the Life of the Church (Woodbridge, 2005), 355.

12 See Handley, 'Reclaiming Ghosts'.

13 Jo Bath and John Newton, "“Sensible Proof of Spirits": Ghost Belief during the Later Seventeenth 
This was partly a result of the mid-seventeenth century revival of Platonism. Henry More was a leading figure; Joseph Glanvill was also won over to the movement. Platonists tended to be more doctrinally flexible than strict Calvinists, and were naturally inclined to look towards classical models rather than more recent ecclesiological policy. ${ }^{14}$ Furthermore, within the context of the Scientific Revolution, supernatural phenomena were considered an interesting subject for investigation, and used to explore the value of empirical analysis. ${ }^{15}$ Nonetheless, most authors explained that their primary motive was to refute atheists. They believed that those who denied the existence of ghosts and witches might easily come to doubt the reality of the immortal soul and the resurrection. ${ }^{16}$ Ghosts could confirm the existence of an afterlife, and also demonstrate providential justice, punishing crimes and righting wrongs from beyond the grave. ${ }^{17}$

In Scotland the religious context was different. As we have seen, Presbyterians utilised divine providences as a propaganda tool. However, ghosts were a step too far for most. Belief in unorthodox supernatural forces was associated with enthusiasm (or religious excesses bordering on superstition). In the 1690s, which Sasha Handley identifies as the key decade in the English rehabilitation of ghosts, the Presbyterians were newly restored to power and had to tread carefully. ${ }^{18}$ Frequently accused by Episcopalians of enthusiastical tendencies, Presbyterian churchmen emphasised their sobriety: 'We are no wayes led by enthusiastick impulses without the word but walk only by the word, and reject all impulses either contrare to, or beside it, yea not warranted by it'. ${ }^{19}$ Alasdair Raffe argues that the period from 1690 to 1730 witnessed

Century', Folklore, cxvii (2006), 3-4.

14 Sasha Handley, Visions of an Unseen World: Ghost Beliefs and Ghost Stories in EighteenthCentury England (London, 2007), 29; Bath and Newton, "'Sensible Proof of Spirits", 7.

15 Handley, Visions of an Unseen World, 35.

16 For example, see Joseph Glanvill, Saducismus Triumphatus (London, 1681), sec. 'Some Considerations About Witchcraft', 3-4 .

17 Peter Marshall, Beliefs and the Dead in Reformation England (Oxford, 2002), 232-64, 261; Thomas, Religion and the Decline of Magic, 701-35.

18 Handley, 'Reclaiming Ghosts.'

19 See Michael Heyd, Be Sober and Reasonable: The Critique of Enthusiasm in the Seventeenth and Early Eighteenth Centuries (Leiden, 1995), 15-23. The quotation is an answer to George Hickes's 1680 The Spirit of Popery, and is cited in Alasdair Raffe, The Culture of Controversy: Religious Arguments in Scotland, 1660-1714 (Woodbridge, 2012), 138. 
'growing ecclesiological and theological rigidity among Presbyterians', partly in response to Episcopalian and Anglican opposition. David Allan similarly notes that 'acute sensitivity to doctrinal error' was an important characteristic of the kirk, and Michael Heyd asserts that a new, 'reasonable' approach to religion developed. As such, 'the conclusion was clear', and was most succinctly expressed by Scots Presbyterian minister James Hog in 1707: 'Visions, voices and Dreams, are no bottom on which we may build, and we ought to cease from regard to them' ${ }^{20}$

However, the fear of atheism was also prominent in Scotland. As Heyd demonstrates, enthusiasm and atheism were often thought to be two sides of the same coin. ${ }^{21}$ The 1689 General Assembly declared that 'there hath been in some a dreadful atheistical boldness against God'. The following decade saw the criminalisation of blasphemy, with the result that Edinburgh student Thomas Aikenhead was hanged in 1697. Persecution continued in the early eighteenth century with the investigation of minister and theologian John Simson for allegedly disseminating heterodox ideas. ${ }^{22}$ Several works emerged that defended miracles and attacked the deists. George Mackenzie's Synopsis Apocalyptica (1708) used miracles and prophecy to refute 'Atheists and Antiscripturists'. ${ }^{23}$ Thomas Halyburton's Natural Religion Insufficient, and Revealed Religion Necessary, to Man's Happiness in his Present State (1714) sought to repudiate Charles Blount and other deists, and criticised John Locke for the importance he placed on rational analysis of revelation.

This fear of atheism and deism drew a few authors towards ghost stories, although

20 Alasdair Raffe, 'Presbyterianism, Secularization, and Scottish Politics after the Revolution of 1688-1690', Historical Journal, liii (2010), 335; David Allan, Scotland in the Eighteenth Century: Union and Enlightenment (Harlow, 2002), 26; Heyd, Be Sober and Reasonable, 175-6.

21 Heyd, Be Sober and Reasonable, 168; M. A. Stewart, 'Religion and Rational Theology', in Alexander Broadie (ed.), The Cambridge Companion to the Scottish Enlightenment (Cambridge, 2003), 33-4; Colin Kidd, 'The Scottish Enlightenment and the Supernatural', in Lizanne Henderson (ed.), Fantastical Imaginations: The Supernatural in Scottish History and Culture (Edinburgh, 2009), 96.

22 General Assembly quoted in Gordon Donaldson, The Faith of the Scots (London, 1990), 104. See Michael F. Graham, The Blasphemies of Thomas Aikenhead: Boundaries of Belief on the Eve of the Enlightenment (Edinburgh, 2008); Anne Skoczylas, Mr Simson's Knotty Case: Divinity, Politics, and Due Process in Early Eighteenth-Century Scotland (Montreal, 2001).

23 George Mackenzie, 'An Essay on the Revelation of St. John', Synopsis Apocalyptica: Or, a Short Plain Explication and Application of Daniel's Prophecy and of St. John's Revelation (Edinburgh, 1708), dedication, i. 
not on the same scale as in England. The royalist John Maitland, first Duke of Lauderdale (1616-82), provided an early example of this reasoning. In 1659 he sent several stories of haunted houses to Richard Baxter, explaining: 'It is sad that the Sadducean, or rather Atheistical denying of Spirits, or their Apparitions should so far prevail; and sadder, that the clear Testimonies of so many Ancient and Modern Authors should not convince them'. ${ }^{24}$ Sadducees did not believe in an immortal soul, nor in the resurrection of the body. In the Bible they were said to believe that 'there is no resurrection, neither angel, nor spirit' ${ }^{25}$ The term was often used in the early modern period to reference those who did not believe in spirits; James VI defined the 'olde error of the Sadducees' as 'denying of spirits' ${ }^{26}$ Maitland's desire to use stories of hauntings against Sadducees or atheists was unusual in Scotland, but not unique. As we have seen, Alexander Telfair published a story of a apparition (in this case, a demonic one) to confute atheists. The best examples, however, are the Presbyterians George Sinclair and Robert Wodrow, who gathered stories in the late seventeenth and early eighteenth centuries respectively. The remainder of this section will look at Sinclair's and Wodrow's motivations, the types of stories they recorded, and the ways in which they put these stories to use.

Sinclair was from the Lothians, and was most likely educated at St. Andrews. He moved to Glasgow in 1655 and was appointed as a professor of philosophy, but refused to submit to Episcopacy and was forced to resign in 1667. He then found employment as an engineer in coal-mines, and was responsible for developing new techniques in draining and measurement with barometers. In 1692, after Presbyterianism was reinstated, he rejoined the university of Glasgow, becoming professor of mathematics and experimental philosophy. ${ }^{27}$ Sinclair first demonstrated his dual interest in natural philosophy and the supernatural in his 1672 Hydrostaticks, a work of theoretical and practical physics that included a description of the demon

24 Richard Baxter, The Certainty of the World of Spirits, and Consequently, of the Immortality of Souls of the Malice and Misery of the Devils and the Damned (London, 1691), 82.

25 Acts 23:8, King James version.

26 James VI, 'Daemonologie, in Forme of Ane Dialogue', in James Craigie and Alexander Law (eds.), Minor Prose Works of King James VI and I (Edinburgh, 1982), preface, xix.

27 John Anderson, 'Sinclair, George (d. 1696?)', Oxford DNB (Oxford University Press, 2009), http://www.oxforddnb.com/view/article/25615, accessed 1 Aug. 2015. 
of Glenluce. ${ }^{28}$ Satan's Invisible World Discovered followed in 1685. It included thirty-nine stories, of which twenty-one or twenty-two were of Scottish origin (one cannot be determined). Sinclair noted that he had taken some stories from Glanvill and More, while the rest were 'purchased from Persons of eminent honesty and Faith' ${ }^{29}$ Witches, ghosts, poltergeists, demonic possession and magical charms all made appearances.

In part this work reflects Sinclair's continued investigations into the workings of the world. He took the supernatural to be a subject of scientific interest, as can be seen from his discussion of the demon of Glenluce within a work on physics. Satan's Invisible World Discovered was dedicated to George Seton, fourth Earl of Winton, because of the latter's interest in coal mining. Sinclair explained to him:

Your Experimental Skill in improving your Coal, for making of Salt, is praise worthie. Your defending of the Salt-pans against the imperious Waves of the raging Sea, from the N.E, is singular. Your renting of Rocks, for clearing of Passages into Your Harbours, which none of your Predecessors were able to do, is stupendious. ${ }^{30}$

However, he also had a more specific aim within Satan's Invisible World Discovered. The work was presented as 'A choice Collection of Modern Relations, proving evidently against the Saducees and Atheists of this present Age, that there are Devils, Spirits, Witches, and Apparitions' ${ }^{31}$ Expanding on this idea in the preface, Sinclair enquired: 'what can be the reason of so much Atheism in the World?' He then explained that

there are a monstruous rable of men, who following the Hobbesian and Spinosian Principles, slight Religion, and undervalue the Scripture, because there is such an express mention of Spirits and Angels in it, which their thick and plumbeous capacities cannot conceive. Whereupon they think, that all contained in the Universe comes under the notion of things matterial, and bodies only; and

28 George Sinclair, The Hydrostaticks, Or, The Weight, Force, and Pressure of Fluid Bodies, Made Evident by Physical, and Sensible Experiments (Edinburgh, 1672), 238-47.

29 George Sinclair, Satan's Invisible World Discovered (Edinburgh, 1685), Av.

30 Ibid., dedication.

31 Ibid., title page. 
consequently, no GOD, no Devil, no Spirit, no Witch. ${ }^{32}$

As this passage indicates, Sinclair's primary concern was with philosophies that placed too much stress on material, rather than spiritual, entities. He was eager not to be seen as narrow-minded, insisting: 'Let no man mistake me, for its not my design to discourage any man that teaches or learns new Philosophy'. However, he added that 'there ought to be layed down some sure principles, as a foundation upon which Students may walk surely, which for their evidence and certainty, may never be called in question' ${ }^{33}$ Although he mentioned Hobbes and Spinoza, Sinclair believed that the main threat to these 'sure principles' was Descartes. He acknowledged that Cartesians did not assert that there was no God, but objected that they 'seem to prove so much'. ${ }^{34}$ As noted above, Cartesianism had become the dominant philosophy taught in Scottish universities (which remained Sinclair's natural milieu, although he was unemployed). Robert Forbes, regent at Marischal College and King's College, Aberdeen, was one of the few anti-Cartesians established in a Scottish university at this point. Forbes had produced a 1680 thesis subtitled 'In defence of the old truth and of the ancient method of philosophising that require defence against the deceitful Cartesian novelty and heterodoxy of this insolent age'. He saw Descartes's use of doubt as a dangerous methodology, and considered Descartes to be moving too far from Scripture and theology as the fountain of knowledge. He noted that

to philosophise freely is permissible, beautiful and worthy of a Christian man: nonetheless, it is truly miserable and grievous to come up with arguments against many, if not all, the opinions received in the Reformed Church and to turn the foundations of religion upside down solely because of contempts for the old method in philosophy and enthusiasm for novelty. ${ }^{35}$

Although Sinclair was out of kilter with most Scottish intellectuals, therefore, he was not alone in perceiving Cartesianism as a threat. His position was not generally representative, but nor was it indefensible by contemporary standards.

32 Ibid., A4v.

33 Ibid., [A7].

34 Ibid., [A5].

35 Giovanni Gellera, 'The Philosophy of Robert Forbes: A Scottish Scholastic Response to Cartesianism', Journal of Scottish Philosophy, xi (2013), 206. 
The extent to which Sinclair had a studied philosophical stance is, however, debatable. The remainder of his preface was dedicated to an exposé of the fifty-four unorthodox beliefs maintained by Cartesians. ${ }^{36}$ Among many other things, Sinclair dismissed Cartesian methodology, arguing that Cartesians placed too much emphasis on reason and the power of philosophy as the 'infallible Interpreter of the Scripture'. He saw the methodology of doubt as sacrilegious. He complained about the Cartesian belief that humans 'can will all things which God can will'. He rejected the notion of animals as automata, and decried the idea that 'the first Chaos, was able of it self, to produce all things material', such that 'God did not creat all things for Man'. However, these points were not original thinking on Sinclair's part; most of them were copied directly from the chapter headings of Petrus van Mastricht's 1677 Novitatum Cartesianarum Gangraena. Many did not actually refer to the beliefs of Descartes at all, but to radical Dutch followers of his, or to other thinkers altogether. ${ }^{37}$ Descartes was a mere straw man; Sinclair's actual engagement with his ideas remained limited.

This is further demonstrated by the fact that the preface's manifold objections to Cartesianism were barely addressed by the material included in Satan's Invisible World Discovered. The most relevant points from the preface were those that concerned spirits and the afterlife. Regarding the nature of spirits, Sinclair objected to Cartesian dualism, noting that according to the Cartesians 'GOD cannot properly be called a Spirit; because (say they) a Spirit, to speak properly, denotes some corporeal thing'. He was concerned about the place of the Holy Spirit, also complaining that Descartes did not distinguish between the three components of the Trinity. In fact, Descartes carefully avoided addressing the nature of the Trinity, although it is true that there was a corporeal element to his notion of 'spirit': he saw man as a spirit and God as a spiritual substance. ${ }^{38}$ Satan's Invisible World Discovered

36 They can be found in ibid., [A5]-[A6v]. Sinclair actually stated that he gave fifty-six reasons, but two - 38 and 39 - are missing. There is some useful discussion in Wasser, 'Mechanical WorldView', 210-18.

37 Raffe, 'Intellectual Change before the Enlightenment', 38-9. I am grateful to Alasdair Raffe for discussion of this subject, and for letting me see a version of this paper prior to publication.

38 Stephen Menn, Descartes and Augustine (Cambridge, 2002), 348; Deborah Brown, 'The Sixth Meditation: Descartes and the Embodied Self', in David Cunning (ed.), The Cambridge Companion to Descartes' Meditations (Cambridge, 2014), 247; M. Glouberman, Descartes: The 
did showcase incorporeal spirits. Corporeal apparitions were also included, however, and Sinclair drew heavily on the work of Glanvill, who argued more explicitly than Descartes that spirits were corporeal. ${ }^{39}$ Sinclair further complained that Cartesians did not believe that death was the separation of the soul and body, nor that the Resurrection was their reunion, and also that they did not see the righteous passing immediately to Heaven nor the wicked to Hell. This was not something Descartes addressed explicitly, although Cartesian dualism already maintained a separation between soul and body, and he does not seem to have believed in the resurrection of the body upon the Last Judgement. ${ }^{40}$ Satan's Invisible World Discovered demonstrated a separation between soul and body after death (as we shall see). However, it was not explicit about whether apparitions came from Heaven, Hell or some intermediate state. Overall, although the preface ostensibly situated the work within a broader philosophical debate, Sinclair made little attempt to engage with precise metaphysical questions through the material included in Satan's Invisible World Discovered. His position, quite simply, was that it was dangerous to doubt the reality of spirits. Satan's Invisible World Discovered therefore aimed to empirically demonstrate their existence.

Even on the topic of spirits, it is difficult to determine Sinclair's exact thinking. Amanda Jane McKeever states that Satan's Invisible World Discovered was 'mainly devoted to ghosts', and 'took ... Glanvill's approach to his subject' ${ }^{41}$ However, Sinclair included more stories about witches than ghosts, and interpreted apparitions demonically to a much greater degree than Glanvill (or most of his other English counterparts). He noted that Glanvill believed that it was the true ghost of Samuel who appeared to Saul. However, he argued that it was much more probable that the apparition was actually the Devil imitating Samuel, pointing out that Samuel 'pretends himself to be disquieted and brought up by Sauls instigation, and the Witches Art, which is most false, impious, and absurd to imagine concerning those

Probable and the Certain (Amsterdam, 1986), 102.

39 Euan Cameron, Enchanted Europe: Superstition, Reason, and Religion, 1250-1750 (Oxford, 2010), 278.

40 Stephen Gaukroger, Descartes: An Intellectual Biography (Oxford, 1997), 199.

41 Amanda Jane McKeever, 'The Ghost in Early Modern Protestant Culture: Shifting Perceptions of the Afterlife, 1450-1700' (University of Sussex DPhil thesis, 2010), 196. 
blessed souls who are returned to their God' ${ }^{42}$ McKeever also writes that Sinclair's presentation of the Glenluce poltergeist shows a 'remarkable turnaround' from poltergeists being demons conjured by witches to poltergeists as ghosts, noting that the spirit of a deceased witch was blamed for the haunting. ${ }^{43}$ Besides the fact that this does not signal a clear shift away from the witchcraft interpretation, McKeever also ignores the way in which the information (that the poltergeist was a witch's spirit) is presented in the story. It is information provided by the Devil, and a minister replies: 'the Lord rebuke thee, Satan, and put thee to silence; we are not to receive Information from thee ... Thou art seeking but to seduce this Family, for Satans kingdom is not divided against it self'. The spirit haunting the house is frequently termed 'the Devil' or the 'Foul Fiend', and elsewhere described itself as 'an evil Spirit, come from the bottomless Pit of Hell', with Satan as a father. Sinclair's account of the Glenluce case does not, therefore, uphold the theory that the poltergeist was a dead spirit. ${ }^{44}$

Even more noteworthy is Sinclair's evaluation of the story of Isabel Heriot. ${ }^{45}$ Isabel was servant to a minister in Ormiston - presumably Sinclair's brother John. ${ }^{46}$ In the winter of 1680 she became ill, and around the time of her death her face turned black. Soon after her burial her apparition was seen, black-faced and wearing the white robes in which she was buried. The apparition threw stones at the minister's house (as Isabel once had when alive). When confronted, the apparition explained that she was returning because she had wronged the minister while alive, and had been charged by the Devil to destroy him. Sinclair resolved that she was most likely a witch. He continued: 'But what could her Apparition be? It behoved, either to be her reall Body informed and acted by the Devil (for her soul could not be brought back) or only the Devil taking upon him her shape and form, acting and imitating her to the life, which is more probable. ${ }^{47}$ Here Sinclair seemed to be taking the traditional Protestant line: the dead soul could not return, and ghosts were tricks of

42 Sinclair, Satan's Invisible World Discovered, A4-A4v.

43 McKeever, 'Ghost in Early Modern Protestant Culture', 152.

44 Sinclair, Satan's Invisible World Discovered, 80, 84-5.

45 Ibid., 144-54.

46 Hew Scott, Fasti Ecclesice Scoticance, new edn, 7 vols. (Edinburgh, 1915-28), i, 340.

47 Sinclair, Satan's Invisible World Discovered, 153. 
the Devil. Although Isabel's case was the only one Sinclair evaluated so explicitly, he also presented other apparitions who seemed diabolic, judging by their unnatural and malevolent behaviour. In a story from Silesia, the apparition of a dead apothecary's servant returned and touched a maid. He left a visible mark, and she fell ill. His body was then dug up and found to be 'putrified with purulent Matter flowing from it'. There was also the case of an executed criminal who roared, thrashed and foamed at the mouth while in his coffin, then made a great 'rumbling and tumbling' after being buried. Thereafter, his former house was haunted. ${ }^{48}$

However, Sinclair also told stories in which ghosts were presented as the genuine spirits of dead people. Most were taken from Glanvill. Major George Sydenham returned to Captain William Dyke to confirm the reality of God and the immortality of the soul; Edward Avon returned to his son-in-law Thomas Goddard to reveal a murder he had committed; Mistress Breton appeared to a servant to ensure that land was given to the poor; and the ghost of Sir George Villiers appeared with warnings about his son's forthcoming murder. In a story from John Webster, a woman returned bearing five large wounds, and revealed that her lover had arranged her murder. ${ }^{49}$ Sinclair also told one Scottish story, from Edinburgh, of a dead woman called Helen Brown who returned to her philandering husband. She reproached him for courting another woman so soon after her death, and invited him to join her. He fell ill and was buried within a month after her death. ${ }^{50}$ Sinclair's approach seems to have been that dead souls could return provided they were on godly business, righting wrongs or upholding Christian values. Malevolent figures such as Isabel Heriot or the Glenluce poltergeist remained the work of the Devil.

Compared to the medieval period, there was no dramatic overhaul in terms of how these ghosts were presented. Medieval ghosts might return because they had died in an unfinished state (rather than to complete a specific mission), whereas Sinclair's ghosts all had useful purposes. ${ }^{51}$ However, medieval ghosts often returned with 48 Ibid., 132-4, 191-2.

49 Ibid., 40-5, 102-8, 128-131, 120-2, 19-22; Glanvill, Saducismus Triumphatus, 219-24, 209-15, 238-42, 225-7; John Webster, The Displaying of Supposed Witchcraft (London, 1677), 298-300.

50 Sinclair, Satan's Invisible World Discovered, postscript.

51 Alexander Murray, Suicide in the Middle Ages, Vol. 2: The Curse on Self-Murder (Oxford, 2000), 
moral or religious functions as well. Sinclair's story of the ghost of Helen Brown echoes the folkloric tradition that contact with the dead could harm the living. ${ }^{52}$ The story from Webster recalls medieval themes of wounded ghosts, and seems inconsistent with Sinclair's insistence on the separation of soul and body after death. Mistress Breton could not rest until her land had been given to the poor, reminiscent of the Catholic notion that salvation came through good deeds (rather than faith alone). None of Sinclair's ghosts were tailored to make a specifically Protestant message. Instead, a subset of traditional stories were revisited. Satan's Invisible World Discovered, overall, has its limitations as a piece of scholarship. Its philosophy is unoriginal, as are its ghosts. Nevertheless, the work is a significant one. The idea of using ghosts to defend against dangerous ideas would have been laughable to Scottish Protestant theologians a century previously. Satan's Invisible World Discovered allowed ghosts to take on a new role within Protestant society.

Sixteen years after the publication of Satan's Invisible World Discovered, the minister Robert Wodrow began his collection of 'remarkable providences'. Wodrow was born in Glasgow in 1679, and elected to the parish of Eastwood in 1703. He was fiercely devoted to the Presbyterian cause throughout his lifetime, and is best known for his record of Presbyterian persecution, The History of the Sufferings of the Church of Scotland, published in two volumes in 1721 and $1722 .{ }^{53} \mathrm{He}$ was a conservative minister; in the words of Richard Sher, he and his fellow 'old-school Calvinists' did their best to 'keep the kirk on the straight and narrow path of their forefathers' ${ }^{54}$ However, he was also the most prolific of the Scottish providentialists. When he died in 1734 his Analecta: Or Materials for a History of Remarkable Providences was still little more than a collection of notes, but it was an extensive collection: when published by the Maitland Club in 1842-3 it spanned four volumes. In addition to the traditional demons, prodigies and benevolent acts of God, Wodrow covered topics

480 .

52 See pp. 39-41, p. 197.

53 For more on Wodrow's life see Louise Yeoman, 'Wodrow, Robert (1679-1734)', Oxford DNB (Oxford University Press, 2004), http://www.oxforddnb.com/view/article/29819, accessed 1 Aug. 2015.

54 Richard B. Sher, Church and University in the Scottish Enlightenment: The Moderate Literati of Edinburgh (Edinburgh, 1985), 45. 
such as angels, second sight and ghosts.

As in the case of Sinclair, Wodrow's work can in part be explained as scientific and geographic investigation, which was growing in popularity over the latter half of the seventeenth century. Wodrow initially wrote that he wished to collect providences to satisfy his 'curiosity and Athenian spirit' ${ }^{55}$ In letters to his correspondents, requests for providences were interspersed with extensive questions about plants, shells and other aspects of nature. For Wodrow, providences were a way to understand how the world worked. He wrote, for example, about how providence regulated the heat levels of human armpits and the temperature of a hen while laying eggs. ${ }^{56} \mathrm{He}$ was an empiricist, collecting information about the natural world in order to theorise; he once wrote to a contact: 'I think we have not as yet a sufficient stock of experiments $\&$ tryalls to build our hypotheses on' ${ }^{57}$ Like Sinclair, however, there was an extra motivation behind his investigations into the supernatural. Wodrow was not simply collecting stories as curiosities. He considered his accounts to have genuine theological import, and frequently underlined the reliability of his sources. In 1717, he explained that he was seeking to confirm 'the great foundations of our holy religion'. Many young people were 'grossly ignorant and unconcerned'. Men and women were not reading and praying every morning as they used to; the ministry was undervalued, and was viewed by many with a 'spirit of jealousy'; and communion services were less popular than they had once been, and were prompting fewer conversions. Even among the faithful, he noted 'a good deal of damp, sinking, and distress ${ }^{58}$ He saw remarkable providences as a means of encouraging Christian feeling. He also noted his desire to show that 'in poor Scotland, the Lord, since the Reformation, hath manifested himself, and the secret of his covenant, to his servants

55 Robert Wodrow, Early Letters of Robert Wodrow, 1698-1709 (Edinburgh, 1937), 285. An 'Athenian spirit' implied that one was always eager for news. See L. W. Sharp, 'Introduction', in L. W. Sharp (ed.), Early Letters of Robert Wodrow (Edinburgh, 1937), xxvii.

56 Robert Wodrow, Analecta: Or Materials for a History of Remarkable Providences Mostly Relating to Scotch Ministers and Christians, ed. Matthew Leishman, 4 vols. (1842-3), ii, 372-3; iii, 310. On Wodrow's scientific interests see Roger Emerson, 'Did the Scottish Enlightenment Emerge in an English Cultural Province?', Lumen: Selected Proceedings from the Canadian Society for Eighteenth-Century Studies, xiv (1995), 8-13.

57 Quoted in Charles W. J. Withers, Geography, Science and National Identity: Scotland Since 1520 (Cambridge, 2001), 86.

58 Robert Wodrow, The Correspondence of the Rev. Robert Wodrow, ed. Thomas M'Crie, 3 vols. (Edinburgh, 1842), ii, 244; i, 46-59. 
and people, as much as any where since the primitive times', ${ }^{59}$

While Sinclair's preface suggests that his work was targeted at a well-educated audience with knowledge of philosophical trends, Wodrow seems to have been more interested in using stories of the supernatural to appeal to his parishioners. Both men, however, were addressing the perceived decline of religious feeling. Sinclair was imitating English works, but Wodrow's collection was very much in the Presbyterian providentialist tradition, although his definition of a providence was unusually broad. He drew from a wider range of sources than Sinclair, and included significantly more material from Scotland. He cited many other ministers as his informants, and also recorded stories from his parishioners. In all, at least twenty different individuals communicated accounts of ghost-like apparitions to Wodrow, and if we include their named sources, the number goes up to around forty-five. Of those, if we allow only apparitions that were definitely identified as returning dead people, we can count eight informants (some of whom gave Wodrow more than one story), with an additional ten or so as their sources. Most were ministers, although the list also includes a servant, a pious lady, and the lawyer and advocate James Erskine, Lord Grange, a keen demonologist who opposed the repeal of the Witchcraft Act. ${ }^{60}$ In addition to these named sources, Wodrow describes several ghost stories as coming 'from several hands' or 'from two or three people'. Overall, his work suggests that ghost stories were still in broad circulation.

Like Sinclair, Wodrow did not reject the idea of demonic apparitions. He was a firm believer in witchcraft, and told stories of the Devil appearing in different guises to trick men. He spoke of a woman in Carstairs who was 'troubled' with apparitions and in need of 'much sympathy', while James Guthrie was said to have been visited by a ghost who disappeared after prayer. ${ }^{61}$ One apparition made a chamberlain's eyes fall out by touching him, and a small, ugly man appeared from Hell to warn about its agonies and tried to destroy a Bible. Wodrow also included a few unpleasant

59 Ibid., ii, 244.

60 See Ian Bostridge, 'Witchcraft Repealed', in Jonathan Barry, Marianne Hester, and Gary Roberts (eds.), Witchcraft in Early Modern Europe: Studies in Culture and Belief (Cambridge, 1996), $321-32$.

61 Wodrow, Analecta, ii, 330, 32. 
poltergeists. ${ }^{62}$ However, for the most part he leant towards casting apparitions in a positive light. He was unusual, for example, in presenting benevolent poltergeists. A sinister laughing voice saved a minister's life by warning him of poison in his food; another poltergeist served as a minister's alarm clock. ${ }^{63}$ Furthermore, Wodrow told several stories of angels (as we have seen, James VI had rejected the idea that angels still appeared to men). He wrote of mysterious strangers arriving in the nick of time to help good Christians by paying their debts, donating food to their families, or rescuing them from wells (falling into wells was apparently a common peril in early modern Scotland). He also presented apparitions playing beautiful music or singing psalms.$^{64}$ In one example, a dying woman was visited by the apparition of a beautiful young child. The two were seen surrounded in a glowing halo, and Wodrow declared it 'a plain instance of the Ministry of Angells' ${ }^{65}$

Furthermore, Wodrow generally presented ghosts as returning dead people, rather than diabolic tricks. A couple returned to reveal murders. The minister Gilbert Rule, Principal at Edinburgh, was obliged to stay in a haunted room. He was visited by the ghost of a tradesman, who led him to the location of his buried bones. The next day Rule gathered together the local people and told the story, accompanying it with a sermon. An elderly man broke down, and confessed to the murder. ${ }^{66}$ Wodrow also presented a few ghosts without an express purpose. Two young boys haunted a room as silent, melancholy ghosts, because they had been sold as slaves during their lifetimes. ${ }^{67}$ However, the most common pattern was for ghosts to return to old friends or family members in order to confirm the reality of the afterlife. In 1729 Wodrow recorded 'a very strange account', explaining that he had been told it by several people 'as what is really belived at Edinburgh, though the persons concerned decline to speak of it, and it's keeped very closs'. Acknowledging the account's 'strangeness' while similarly underlining its credibility was a common strategy of Wodrow's when introducing his more theologically questionable providences. In this particular story,

62 Ibid., i, 159, 95-7, 112-14. On the man from Hell see p. 7, above.

63 Wodrow, Analecta, iv, 110; ii, 307.

64 Ibid., i, 53-4, 57, 222; ii, 180-1, 307, 322; iii, 89.

65 Ibid., ii, 142-4.

66 Ibid., iv, 87-90.

67 Ibid., iv, 91. 
a girl sprained her arm in a dance at an Edinburgh Assembly, and then entered a decline. When she was drawing close to death her brother came to entertain her with music and dancing. This brother was 'a youth about seventeen, very rackish, and loose in principles, at best a Deist'. The girl objected that she wished to remain in a serious frame of mind. Wodrow continued:

He insisted that she was roving, and should be diverted; and told her he did not belive ther was any thing after death to fear, and wished she might not belive any thing she sau not, and make herself easy. She answered, She did belive she had an immortall soul; that ther was a heaven and a hell. His words I do not repeat, being horrid, but ended with that:- 'Girl, when thou dyes, if ther be any thing in those dreams, come back and tell me! I belive none of that preistcraft!' When she died, it's confidently said she appeared to him. What passed is not told; but this is certain, the youth came running, like one distempered, to my Lord, his father, his room, in his shirt, as I am told, all in sweat, and told what passed. ${ }^{68}$

The fashionable, rakish young man with the lax religious principles is very much the kind of character Wodrow was keen to reform, and the story offers a clear example of how ghosts could be utilised to that end. When a ghost made regular visits to Archibald Pitcairne (who was rumoured to be an atheist), Wodrow explained that the episodes were 'vouchsafments of Providence' and 'methods of conviction'. ${ }^{69}$

As in the case of Sinclair, the religious message of Wodrow's ghosts was relatively vague. Consider the story of John Middleton, first earl of Middleton (c. 1608-74) and James Wood, the Laird of Balbegno. This story offers an interesting example of how Wodrow's interpretation of apparitions differed from that of most Presbyterian providentialists. Middleton and Balbegno made a pact that whoever died first should return to report on the afterlife. Balbegno was killed in battle in 1651, and reportedly appeared to Middleton while the latter was imprisoned in the Tower of London. The story was recorded by Robert Law in his Memorialls. Law explained that it was the Devil in Balbegno's likeness who visited Middleton. ${ }^{70}$ While Law would probably have judged all ghosts to be diabolic, he had particular reason to dismiss this one.

68 Ibid., iv, 45-6.

69 Ibid., iii, 520-2. On Pitcairne see pp. 141-3.

70 Robert Law, Memorialls: Or the Memorable Things That Fell out Within This Island of Brittain from 1638 to 1684, ed. Charles Kirkpatrick Sharpe (Edinburgh, 1818), 162. 
Middleton was an Episcopalian, and the ghost held similar sympathies. Law, on the other hand, was a strict Presbyterian, and was deposed after the 1660 Restoration. He was almost certainly writing before the 1689 reinstatement of Presbyterianism, and would naturally be hostile towards an Episcopalian ghost. ${ }^{71}$ When Wodrow recorded the same story, however, he asserted that it was the true ghost of Balbegno who returned, telling Middleton 'of many things to come, of his oun delivery out of prison; of the King's Restauration, and that he should be in favour with him, and in the highest trust in the kingdome'. ${ }^{72}$ Admittedly, Wodrow was writing in 1702, and thus from a position of relative security. Even so, it is interesting that he would present an Episcopalian ghost in a relatively favourable light. Tensions between Presbyterians and Episcopalians had by no means disappeared after 1689, with debates about toleration dominating the religious scene in the run-up to the 1707 union with England..$^{73}$ Many of Wodrow's other providences emphasised God's favours for loyal Presbyterian ministers. Wodrow's ghosts simply did not concern themselves with the wrangling between Presbyterians and Episcopalians, instead delivering more general religious messages.

Just as Episcopalianism remained an important concern while Wodrow was working, Catholicism had not disappeared as a threat to the kirk. In 1685, the same year that Satan's Invisible World Discovered was published, the Catholic James VII ascended to the Scottish throne. James attempted to introduce limited toleration for Catholics, and was deposed four years later in favour of the Protestant William and Mary of Orange. Jacobite support for James and his descendants ensured that the possibility of a revolution and a Catholic monarch lingered on for much of the eighteenth century. Nonetheless, in Wodrow's collection as in Sinclair's, ghosts had not been completely purged of their medieval elements. One particularly interesting story is preserved among Wodrow's manuscripts. Originally from London, the story was

71 Law's work covered the period up to 1684. Vaughan T. Wells writes that Law died around 1686. Vaughan T. Wells, 'Law, Robert (d. c.1686)', Oxford DNB (Oxford University Press, 2004), http://www.oxforddnb.com/view/article/16152, accessed 1 Aug. 2015.

72 Wodrow, Analecta, i, 34-6.

73 See Ryan K. Frace, 'Religious Toleration in the Wake of Revolution: Scotland on the Eve of Enlightenment (1688-1710s)', History, xciii (2008), 355-75; Karin Bowie, Scottish Public Opinion and the Anglo-Scottish Union, 1699-1707 (Woodbridge, 2007); Jeffrey Stephen, Scottish Presbyterians and the Act of Union 1707 (Edinburgh, 2007). 
communicated to Wodrow in a letter by Scottish Presbyterian minister James Cowan around 1707, along with accounts of an angelic visitation and a resurrection. ${ }^{74}$ It concerned a lady called Mary Turberville, who was visited by the ghost of her deceased landlady. The figure was hideous, clad in black, and gave off a 'Noysom smell'. She was also violent; when Mary ventured to speak to her she swore that if Mary had not spoken first 'I would have torn you, \& thrown you down Stairs'. She revealed that she had broken a promise to her late husband by not donating money to the poor. Mary found and donated this money, after which the ghost reappeared in shining white, with a 'pleasent beautifull and Smileing Countenance'. She answered some questions of Mary's, and soon afterwards was carried away to Heaven by a beautiful young child.

As we have seen, the pattern of ghosts changing from black to white clothing was relatively common in the medieval period, and represented the progression of the soul through Purgatory. Furthermore, the landlady's ghost asserted that after her death she had gone neither to Heaven nor to Hell, but was 'under great horror'. Despite these none-too-subtle references to Purgatory, this story seems to have circulated widely. Cowan claimed that it had evoked great interest in many Scottish gentlemen. This assertion is supported by the fact that James Garden, Episcopalian professor of theology at Aberdeen, wrote to John Aubrey about the story in 1695. Garden specifically mentioned the ghost's changing from black to white, and asked whether it was true. ${ }^{75}$ The persistence of Catholic themes has been played down within the English historiography. Handley writes that Protestant authorities stripped ghost stories of their 'popish associations'. Owen Davies argues that in postReformation England the symbolism of ghosts changing from black to white clothing 'was obviously rendered redundant', while Belinda Lewis writes that postReformation ghosts were almost invariably presented as coming from Heaven or Hell. ${ }^{76}$ However, the process of reclaiming ghost stories, at least in Scotland, was not

74 These letters are transcribed in the appendix, pp. 259-71.

75 Quoted in Michael Hunter (ed.), The Occult Laboratory: Magic, Science, and Second Sight in Late Seventeenth-Century Scotland (Woodbridge, 2001), 158.

76 Handley, 'Reclaiming Ghosts', 354; Owen Davies, The Haunted: A Social History of Ghosts (New York, 2007), 22; Belinda Lewis, 'Protestantism, Pragmatism and Popular Religion: A Case Study of Early Modern Ghosts', in John Newton and Jo Bath (eds.), Early Modern Ghosts 
quite this streamlined, and medieval remnants did linger within the corpus.

Overall, Sinclair and Wodrow favoured purposeful ghosts, sent by God. Violent medieval revenants were relatively rare, and were not associated with the souls of the dead. The ghosts of Wodrow and Sinclair most often looked like normal humans, rather than walking corpses. In one story told by Wodrow the ghost explained that he had borrowed an 'aerial body' for his visit. ${ }^{77}$ Nonetheless, Sinclair and Wodrow reappropriated ghosts, rather than recreating them. This indicates that traditional ghost beliefs had survived, despite having been cast out of orthodox religious culture. Furthermore, the vagueness of the religious message reaffirms the idea that these stories were not targeted at those of the wrong Christian persuasion, but rather at those whose philosophies might lead them to doubt basic religious tenets altogether. It was only in the late seventeenth century that ghosts were revisited in a serious way by Presbyterian ministers because it was only then that atheism had emerged, not necessarily as a more important concern than Episcopalianism or Catholicism, but at least as a significant rival.

\section{Second Sight and Wraiths}

Ghosts and ministering angels were not the only supernatural beings to be reclaimed in the late seventeenth and early eighteenth centuries. Robert Kirk (c. 1644-92), the Episcopalian minister of Aberfoyle, wrote about fairy beliefs among his parishioners in The Secret Commonwealth of Elves, Fauns and Fairies (completed in 1691). He gave fairies a theological explanation and significance, placing them within the Christian framework. He explained that they were 'of a midle nature betwixt man and Angell', and argued that they served as proof of the world of spirits and so furnished a defence against atheism. ${ }^{78}$ However, when Lizanne Henderson and Edward J. Cowan take Kirk's Secret Commonwealth to mark the 'reinstatement of (Durham, 2002), 79.

77 Wodrow, Analecta, i, 265; 126-7.

78 Robert Kirk, 'The Secret Commonwealth of Elves, Fauns \& Fairies', in Michael Hunter (ed.), The Occult Laboratory: Magic, Science, and Second Sight in Late Seventeenth-Century Scotland (Woodbridge, 2001), 79, 96. 
fairy belief', they are probably overstating the case. ${ }^{79}$ Kirk was an exceptional figure. For most authors, fairies remained in the domain of superstition, and Wodrow and Sinclair avoided them. The Highland phenomenon of second sight garnered more interest. Second sight was a gift that allowed people to see into the future. In 1678, English natural philosopher Robert Boyle enquired about second sight during an interview with George MacKenzie, Lord Tarbat. Boyle was looking for ways to prove the reality of the supernatural in the face of declining witch beliefs. The Welsh polymath Edward Lhuyd and the Englishmen Samuel Pepys and John Aubrey subsequently took an interest. ${ }^{80}$ There were also several Scotsmen who investigated and wrote on the topic. Both Kirk and Wodrow recorded second sight beliefs. Martin Martin (d. 1719), a native of Skye, wrote about second sight in his $1703 \mathrm{~A}$ Description of the Western Isles of Scotland, while Dean of the Isles John Fraser (1647-1702) explored the topic in his Deuteroskopia, or A Brief Discourse Concerning the Second Sight (1707). ${ }^{81}$

Second sighted people often saw apparitions presaging oncoming marriages, deaths, or grander affairs such as battles. The most common way to predict death was to see a vision of the person who was to die either dressed in a shroud or other deathgarments, or carried by a spectral funeral procession. These apparitions appeared before death, but were otherwise similar to ghosts. ${ }^{82}$ Their nature was debated. As early as 1623, the poet William Drummond of Hawthornden (1585-1649) declared:

it hath beene ever and of all held as infallible and most certaine, that [the soul] often (either by outward inspiration, or some secret motion in it selfe) is augure of its owne Misfortunes, and hath Shadowes of approching dangers presented unto it before they fall forth. Hence so many strange apparitions and signes, true Visions, uncouth heavinesse, and causelesse uncomfortable languishings: ${ }^{83}$

79 Lizanne Henderson and Edward J. Cowan, Scottish Fairy Belief: A History (East Linton, 2001), ch. 6 (quotation from the chapter title).

80 Michael Hunter, 'Introduction', in Michael Hunter (ed.), The Occult Laboratory: Magic, Science, and Second Sight in Late Seventeenth-Century Scotland (Woodbridge, 2001), 8-9.

81 See Hunter, Occult Laboratory. See also Martin Rackwitz, Travels to Terra Incognita: The Scottish Highlands and Hebrides in Early Modern Travellers'Accounts, c.1600 to 1800 (Münster, 2007), 505-10.

82 This was not just a Scottish phenomenon; Lavater discusses these funeral processions as well. Ludwig Lavater, Of Ghostes and Spirites Walking by Nyght, trans. Robert Harrison (London, 1572, STC 15320), 79.

83 William Drummond, Flowres of Sion ([Edinburgh], 1623, STC 7247), 45. 
Kirk linked second sight apparitions to fairies (an unusual approach) ${ }^{84}$ It was more common to interpret them as divine or diabolic. Sinclair declared that it is not improbable but that such preternatural knowledge comes first by a compact with the Devil'. John Fraser toyed with the idea that either angels or demons might be responsible for second sight apparitions. ${ }^{85}$ Wodrow turned premonitions into a gift from God. His stories revolved around pious ladies and gentlemen, rather than the Highland peasants more usually associated with second sight. A lady who had a prophetic dream was 'of great piety and good sense, and noe visionary'; a man who had a premonition of a fire was 'of very considerable sense and learning, and of an excellent and fair character, not to be imposed on by fancy and vapours' ${ }^{86}$ Wodrow even asked a friend if he could send him cases of second sighted men who were 'piouse and treuly Religiouse' and 'free from all suspicion of a Compact with Satan' ${ }^{87}$ In the case of second sight we again see the survival of old ideas that apparitions were linked to demons, but also an attempt to transform them into something godly.

The Lowland equivalent of second sight apparitions was the wraith (often termed a 'fetch' in English and Irish folklore). As we have seen, James VI defined a wraith as the spectral appearance of a person either soon before their death, or when 'newlie dead' (in practice, this generally meant at the precise moment of death). Unsurprisingly, James argued that wraiths were actually the Devil. ${ }^{88}$ Robert Kirk conflated wraiths and second sight apparitions, and outlined a range of popular interpretations, explaining that some second sighted folk believed that 'what the Low-countrey-Scot calls a Wreath ... is only exuvious fumes of the Man approaching death, exhal'd and congeald into a various likeness ... and are neither Souls nor Counterfeiting Spirits. Yet not a few avouch (as is said) that surly these are a

84 Kirk, 'Secret Commonwealth', 79-80.

85 Sinclair, Satan's Invisible World Discovered, 215-16; John Fraser, 'Deuteroskopia', in Michael Hunter, The Occult Laboratory: Magic, Science, and Second Sight in Late Seventeenth--Century Scotland (Woodbridge, 2001), 199-201.

86 Wodrow, Analecta, i, 281; iv, 105. This reference to 'vapours' meant the hallucinogenic fumes of melancholy.

87 Questionnaire reproduced in Hunter, Occult Laboratory, 207.

88 James VI, 'Daemonologie', bk. iii, ch. i, 42. 
numerous people by themselves. ${ }^{, 89}$ Sinclair seemingly had more patience for wraiths than for second sight, as he included a story of one. A man appeared to a close friend and looked at him with a 'ghaistly and Pale countenance'. His friend, clearly knowledgeable in the ways of ghosts, addressed him: "what art thou? Art thou my dear Friend Thomas Coltheart? ... Art thou dead my friend? Tell me, if thou hast any commission to me from Almighty God, tell it me and it shall be welcome?' The apparition shook his hand at his friend three times, and vanished. He was later established to have died at that moment. ${ }^{90}$

Sinclair's story conveniently illustrates both the similarities and differences between wraiths and ghosts. In terms of appearance they were indistinguishable, but wraiths did not tend to fulfil useful purposes or deliver religious messages. Furthermore, they were even more guilty than ghosts of perpetuating unorthodox folkloric traditions. In 1711, the husband of Lady Teviot of Cromarty appeared to her at the moment of his death, looking 'black and oily' - possibly a reference to discolouration after death, but perhaps a reflection of the aforementioned medieval notion that the dead appeared in black before they had passed through Purgatory. ${ }^{91}$ Wraiths also demonstrate the importance that early modern society attached to the moment of death. In the Middle Ages there was a popular belief that a dying person's state of mind for the second prior to death determined whether they were bound for salvation or damnation - a belief that was unorthodox by both Catholic and Protestant theology. Philippe Ariès argues that 'after the sixteenth century, the actual moment of death, in the bedroom and in the bed, will be more or less abandoned by pious writers, at least by scholarly ones'. ${ }^{92}$ However, wraiths indicate that the importance of the final moment had survived as an idea. ${ }^{93}$

89 Kirk, 'Secret Commonwealth', 83.

90 Sinclair, Satan's Invisible World Discovered, postscript. See also Relation XVI, 120-2, and Relation XXIX, 187-91.

91 William Fraser, The Earls of Cromartie, Their Kindred, Country and Correspondence, 2 vols. (Edinburgh, 1876), i, ccvi-ccvii. Fraser explains that he is quoting a manuscript then in the Cromartie repositories at Tarbat House and signed by Robert Keith, whom Fraser believes to be the historian and bishop (1681-1757).

92 Philippe Ariès, The Hour of Our Death, trans. Helen Weaver (Oxford, 1981), 298.

93 See also Richard Wunderli and Gerald Broce, 'The Final Moment before Death in Early Modern England', Sixteenth Century Journal, xx (1989), 259-75. 
Moreover, the wraith did not depict an appropriate Christian attitude towards death. It was a poignant figure, and suggested that the dying person's last thoughts were of earthly friends or family members rather than the world beyond. James Cowan passed a wraith story on to Wodrow around 1707. ${ }^{94}$ It concerned a Mr Short, and dated from about ten years previously, when Short was doing his trials in the Presbytery of Earlston. He was lying in bed awake at about five o' clock in the morning when he saw the apparition of John Scrimzeor, a good friend and fellow trainee minister. Short had seen Scrimzeor in a 'sickly condition' in Edinburgh a few days previously. Scrimzeor approached the bed, looked at Short, and turned away. He then departed, leaving Short 'a trembling and sweating for a considerable time'. When he got up Short travelled to Edinburgh and made enquiries, only to find that Scrimzeor had died at the precise time he had seen the apparition. Scrimzeor was described as having a 'heavy, mournfull-like countenance' - hardly suggesting the joy a good Christian should feel about proceeding to Heaven. Like ghosts, these apparitions were reclaimed and turned into messages from God, but they were not thoroughly purged of unorthodox elements.

\section{Resurrections}

Resurrection stories were similar to ghost stories, in that they also presented the return of the dead. Admittedly, stories of post-mortem revivals were not necessarily supernatural. Deficiencies in early modern medical knowledge resulted in cases of people being buried alive. This was a recognised theme in folklore, and Scotland had its own version of a folk-tale, found throughout Europe, in which a grave-robber awakens a recently-buried woman while trying to steal her ring. ${ }^{95}$ However, even when they were not obviously supernatural, resurrection stories often took on status

94 Wodrow, Analecta, i, 97-8.

95 Jan Bondeson, Buried Alive: The Terrifying History of Our Most Primal Fear (New York, 2002), 31-50. In the Scottish version the woman was often said to be Margaret Halcro Erskine, originally from Orkney, who supposedly had an initial 'death' in 1670 or 1674 before finally dying in 1725. Another candidate was Marjory Elphinstone, second wife of Robert Drummond of Carnock, who lived near Inverurie and died in the early seventeenth century. James Tait, Two Centuries of Border Church Life, 2 vols. (Kelso, 1889-91), ii, 14-15. 
as providences. If a prisoner revived after execution, for example, it could be taken as a divine judgement. A 1724 broadside recounted the story of a woman called Margaret Dickson, who was hanged for infanticide. Her body was cut down and given to her friends, but the men taking it away stopped at a village for a drink. While they were drinking, one of the men saw the lid of the coffin move. He opened it, and Margaret sat up in her coffin. After being bled she went on to make a full recovery. Her resurrection was taken as a suggestion of her innocence, with the broadside declaring: 'She still continued to deny that she had committed the crime. From her example, and the uncertainty of her guilt, it is to be hoped that juries will be cautious how they find a verdict where the case may appear doubtful. ${ }^{96}$

Wodrow preserved even more wondrous resurrection stories, using them to make religious points just as he would with ghosts. In accounts of this sort the resurrection was often temporary, with the corpse lying down dead again after delivering its message. A typical story was told to Wodrow by a Mr A. Simson, who heard it from the Minister of Penpont. Around the year 1676, the body of a recently-deceased child was found buried in a yard in Penpont. The minister ordered the child to be brought to the kirk, and for the people to convene. After many others had passed by, a man approached the child, and the child raised its hand and pointed at him. This so struck the man's conscience that he immediately confessed to being the father of the child, to having 'begotten it in incest on his wife's sister', and to being privy to its murder. ${ }^{97}$ This story reflects contemporary concerns: kirk sessions were keen to clamp down on sexual immorality, and illicit sexual relations and infanticide were topical and provocative misdemeanours. It is also interesting to consider how the story ended. Wodrow explained that the man 'was secured and delivered to the Shirrife, and I think the sentence of death was passed on him; but having means, he bribed the Shirrife and gote off'. The point to the story was not that early modern justice systems would necessarily prevail, but that God had not forgotten the man's sins.

96 Margaret Dickson's Penetential Confession ([Edinburgh], [1724]); see David Nash and AnneMarie Kilday, Cultures of Shame: Exploring Crime and Morality in Britain 1600-1900 (Basingstoke, 2010), ch. 3.

97 Wodrow, Analecta, i, 86-7. 
People might also be revived to reveal the nature of the afterlife. Analecta records cases of a daughter who sat up on her father's prayers to reassure him that she was with Christ, and a woman who arose to declare that she was condemned to Hell for 'lying, backbeiting, and slandering of my nighbours'. Sinclair told a similar story, of a corpse rising to declare that it was condemned..$^{98}$ The best example, however, is another story from James Cowan. It concerned a Sussex lady 'of rare and eminent piety'. ${ }^{99}$ After she died from an illness, her husband was inconsolable. He would not allow his friends to have the corpse removed, despite all their chiding that he 'acted neither like a man nor a Christian'. Eventually God granted his wish, and his wife was resurrected. She explained that she had arrived at the throne of Jesus, only to be informed that she was not yet to be judged, but had to return to Earth and 'undergo a Course of sufferings'. She described her experience, drawing heavily on biblical language and motifs. She was borne upwards by angels, like Lazarus; her resurrection came after three days of death, like that of Jesus; and her Heaven was based on St. John's Revelations. Her vision of Heaven was theocentric, focused on the eternal worship of God. Under the influence of Luther and Calvin this had become the orthodox Protestant perspective over the seventeenth and eighteenth centuries (during the Renaissance a more human, sensual Heaven had been fashionable). ${ }^{100}$ Besides presenting the proper view of Heaven, the account also refuted unorthodox philosophies such as mortalism, which asserted that the soul slept until the Last Judgement. It even demonstrated the correct Christian attitude towards death: the lady was angry to have been dragged back by her husband's selfishness, and on seeing her body she 'had this Murnifull and Melancholy reflection, Must I again reenter, that dead stinking Carcass wherein I have sinned and suffred so much'.

As we have seen, the ghosts recorded by Wodrow and Sinclair did not generally return in their own corpses. The implication was that the soul returned while the body remained in its grave, maintaining the clean separation between body and soul after death that Sinclair advocated. Resurrections complicate this picture, but are not

98 Ibid., iv, 46; i, 117-18; Sinclair, Satan's Invisible World Discovered, 156-7.

99 See appendix, pp. 267-71.

100 Colleen McDannell and Bernhard Lang, Heaven: A History, 2nd edn (New Haven, 2001), 14655. 
inconsistent. The Sussex lady's soul clearly left her body after death, and was forced to return there later. The corpses who rose briefly to explain their fate after death were, it is implied, briefly allowed to do so by God before their souls departed their bodies once more. Alternatively, perhaps God himself manipulated the dead body. These stories do suggest that, with God's permission, the corpse could retain vitality. However, they represent a clear progression from the violent medieval revenants, which did not generally return with good Christian messages. Again, old traditions were revisited and depicted in a newly positive light.

\section{Theological Controversy and the Laird of Coul's Ghost}

While Wodrow and Sinclair used ghosts to defend Christianity in general, there were also cases of ghosts being employed towards more precise theological ends. The Episcopalian bishop Thomas Rattray (1684-1743) was one figure whose interest in ghosts was probably linked to a specific religious agenda. A story was reported to him and three witnesses (including his two sons) on 30 December $1730 .{ }^{101}$ The story was also told in the English Gentleman's Magazine in 1731, with the explanation that it had been published in Scotland. ${ }^{102}$ It concerned a man called William Souter, who lived in Middle Mause, Perthshire. Over a two-year period from December 1728, he was haunted by a large grey dog. He had sightings of it every few months, but it was invisible to his brother and servants. Once it brushed against his thigh, leaving him with a strange pain all night. Eventually the dog began to talk to him, and arranged a meeting. Souter took a sword and staff. After waiting a little, he drew a circle about himself with the staff. The dog promptly appeared, and Souter cried: 'In the name of God and Christ Jesus what are you that troubles me?' The dog replied that he was Souter's uncle. He had killed a man thirty-five years ago. As he had committed the murder with a dog, he was compelled to appear as one. He had left the bones under a bush at the roadside, and was unable to rest until he had seen them properly buried.

101 Thomas Rattray, account of the Ghost Dog of Mause, 31 Dec. 1730: NRS, GD377/448. See also Maurice Fleming, The Ghost O'Mause: And Other Tales and Traditions of East Perthshire (Edinburgh, 1995).

102 Handley, Visions of an Unseen World, 126-7. 
Souter went to the minister with his story, and after obtaining the landowner's permission several dozen local men gathered together and made a search for the bones. They looked for many hours, but found nothing, and eventually departed. The dog returned soon afterwards, explained that the bush was old and withered, and promised to leave an ' $\mathrm{X}$ ' beside it. This time, after some hours of searching, Souter found a great cross, about a foot and a half in length and more than an inch deep. He took a spade and dug into the ground. Before long he had uncovered the bones of the dead man. He commissioned a coffin to be made for them, and a proper burial was held for the murder victim, attracting almost a hundred folk.

Ghosts as black dogs were a common theme in English folklore, particularly in the south. However, in Scotland black dogs were usually emanations of the Devil. ${ }^{103}$ It was rare for ghosts to appear as animals - although as we have seen, it was a theme in the medieval period. The story also had other unorthodox features. There were flavours of necromancy in the circle drawn by Souter, and the idea that the bones should be buried in consecrated ground was against the Calvinist belief that all of God's earth was equally sacred. Nevertheless, Rattray believed the story. He wrote that it was 'as remarkable as perhaps anything you ever heard of', and 'leaves (I think) no ground of doubt to any man of sense'. This could simply mean that he valued the account as proof of the world of spirits, but if we set the Ghost Dog to one side for the present and consider another eighteenth-century story, Rattray's precise agenda will become clearer.

The best-known proselytising ghost of the eighteenth century was the Laird of Coul. 'Coul' (also Cool, Cule or Cuil) was derived from the Gaelic cùil, meaning a corner or nook, and several Scottish estates bore the title. This particular Coul was a small estate in the parish of Buittle, in Galloway. From 1715 its laird was Thomas

103 On England see Theo Brown, 'The Black Dog', Folklore, lxix (1958), 175-92. There are nine examples of the Devil appearing as a black dog in Julian Goodare et al., The Survey of Scottish Witchcraft (University of Edinburgh, 2003), http://www.shca.ed.ac.uk/witches, accessed 1 Aug. 2015. There are multiple more with the Devil merely as a dog. See also the black dog that appears in A Full True and Particular Account of the Most Dreadful Apparrition: Of Robert Watt WineMerchant in Edinr, Who Appeared to James Macdonald Plaisterer in Lieth-Walk ([Edinburgh?], [1794?]), and the brown dog that appears in the company of the ghost of Edward Avon in Sinclair, Satan's Invisible World Discovered, 107. 
Maxwell, a lawyer. He was said to have a 'tarnished reputation', having dealt dishonestly with his lands. P. H. McKerlie explains:

Among other things he had the estate of Ballycastle, Londonderry, Ireland, conveyed to him in trust by his cousin Sir George Maxwell of Orchardtoun, parish of Rerwick, giving a bond that he would convey it back to Sir George in liferent; to his wife, Lady Mary, Dowager Viscountess Montague, if she survived him; then to the Earl of Nithsdale and his heirs male; and failing them, to the third son of the Earl of Traquair. However, instead of adhering to this, along with Cuil he conveyed the lands not his own to his wife Isobel Neilson on the 14 October $1720 .{ }^{104}$

Maxwell died in January 1722. The first accounts of his ghost appeared in February 1723. The story was reported by William Sinclair, Maxwell's ex-servant, then employed by a physician called Mr Menzies. Sinclair spoke of it to Robert Paton and Patrick Linn, ministers of Dumfries, and Thomas Mack, minister of Terregles; these ministers wrote the story down and, at least in Mack's case, passed it on. ${ }^{105}$ Sinclair explained that a fortnight previously he was moving down the stairs when he became afraid and started to sweat, without knowing why. He continued to head out to his new master's stables. His dog, who usually tagged at his heels, ran back into the house, and ignored his calls to come back. Sinclair continued anyway, up to the loft of the stables. There he saw that the horses had stopped eating. Looking down, he saw the Laird of Coul, wearing his customary white coat and knotted wig. Coul called at him to come down from the loft, explaining that he could not rest until he had told Sinclair something. Sinclair refused, saying that he had nothing to do with anyone but God and his current master. The apparition then vanished.

Coul reappeared the following week when Sinclair was on his way to Kirkgate. He accompanied Sinclair to the kirk without speaking, but lingered behind at the kirk stile. On Sinclair's way back he appeared again, wearing black clothes this time, and asked Sinclair to walk with him. They reached a bridge. Sinclair saw a large, deranged-looking greyhound with an open mouth, which vanished, and a man. $\mathrm{He}$ 104 P. H. McKerlie, History of the Lands and Their Owners in Galloway, 5 vols. (Edinburgh, 18709), iii, 273.

105 Account of the Laird of Coul's ghost, 12 Dec. 1723: NRS, CH12/12/755; Account of the Laird of Coul's ghost, 12 Feb. 1723: NRS, CH12/16/251; Thomas Mack to Robert Wodrow, 15 Feb. 1723: NLS, Wod.Lett.Qu.XIX, fos. 283-284. 
then heard a great sigh, as though of wind, and darkness surrounded him. He lost his senses, and when he recovered he was at the foot of Millburn at the side of a river. There was a boat and a party of people, mostly women. Coul was among them, wearing a blue coat. Sinclair prayed, and the vision vanished; then he lost his senses again, and came to himself at the moat of Dumfries. The same people appeared once more, only in greater numbers. Coul began to entreat Sinclair to enter his service, displaying handfuls of gold. In Mack's version his skin colour was gradually darkening until he became black. Sinclair tried to leave, but people blocked his way, and some began to change shape, shifting into great toads. Coul promised he would not be harmed, and began to detail debts he had incurred which had not been discharged. He wanted Sinclair to explain these debts to his widow, and added that if he did not, something extraordinary would come upon him. Sinclair ignored these pleas, and prayed determinedly. The party vanished, and he was allowed to depart. Not long afterwards, however, he was watering two horses when a great black horse with an unknown rider appeared, bearing down on him. One of the horses fell down dead on top of him, leaving him badly 'crushed and bruised'. The other horse died the next day. It was at this point that Sinclair decided to speak with the ministers.

The ministers' accounts end here. The 1892 edition of the chapbook supplies the following supplement: 'At some subsequent appearance while the lad was about the same business, whether Coul had done him any real harm, or that the lad had fallen from his Horse thro' Fear \& Confusion is uncertain; But so it was that the Lad was found Dead on the Road'. ${ }^{106}$ The minister William Ogilvie (on whom more below) gave a slightly different version, explaining that on the first meeting the ghost noted Sinclair's confusion and arranged an appointment for the next day. Sinclair consulted the minister Robert Paton on whether he should keep the appointment, and was counselled against doing so. Not long afterwards he was riding with another young man when the laird of Coul attacked him with a mallet. His companion could see nothing, but Sinclair's horse fell down dead, and Sinclair explained that Coul had struck its forehead. ${ }^{107}$

106 William Ogilvie, The Laird O'Coul's Ghost, ed. J. F. S. Gordon (London, 1892), 20n1.

107 Frank Miller, 'The Laird of Coul's Ghost: A Galloway Chap-Book', Transactions of the Dumfriesshire and Galloway Natural History \& Antiquarian Society, 3rd ser., xiv (1927), 261. 
This story is a patchwork of different traditions. In parts, it follows folkloric conventions for ghost stories. Animals shrinking away from the ghost was a common pattern, as was Coul's appearance in the clothes he wore during his lifetime (although it is unclear why he had to change outfits so often). His need to rectify mistakes and sort out unfinished business before he could rest was in line with medieval tradition. However, the story also incorporates the Reformation picture of the ghost as a Devil, and there are obvious crossovers with witchcraft discourses. The party on the boat was clearly influenced by stories of the Sabbat, the night-time gathering where witches paid homage to the Devil. ${ }^{108}$ Coul took on the role of the Devil by offering Sinclair gold for his allegiance, another standard feature of witch stories. The letter which speaks of Coul's skin turning black is even more suggestive, as the devil was frequently depicted as a black man. ${ }^{109}$ The fact that the vision vanished when Sinclair prayed was similarly an indication that evil was afoot (note also Coul's unwillingness or inability to go too close to the kirk). Nonetheless, the story did not wholly commit to a diabolic view of Coul; it is interesting that he resumed grieving over his debts even as people were turning into toads around him. The story shows a degree of doubt as to the precise nature of the ghost. By the 1720s the witch trials were dying out; it is notable that this medley of ghost, Devil, witches and shapeshifters was taken seriously enough to be recorded and passed on.

However, it was the next account of Coul's ghost that made him a famous figure. This version was penned by William Ogilvie (c. 1688-1729). According to his daughter Henrietta, Ogilvie was the younger son of a gentleman with a small estate in the south. This gentleman was presumably a Covenanter, as he was said to have been in hiding for three years before the Glorious Revolution. Ogilvie was educated in Edinburgh, and served as chaplain to the seventh dragoons in London. He was admitted as minister of Innerwick, East Lothian, in $1715 .{ }^{110}$ One of his fellow

108 For a basic overview see Jonathan L. Pearl, 'Sabbat', in Richard M. Golden (ed.), Encyclopedia of Witchcraft: The Western Tradition, 4 vols. (Santa Barbara, 2006), iv.

109 See Joyce Miller, 'Men in Black: Appearances of the Devil in Early Modern Scottish Witchcraft Discourse', in Julian Goodare, Lauren Martin, and Joyce Miller (eds.), Witchcraft and Belief in Early Modern Scotland (Basingstoke, 2008).

110 Miller, 'Laird of Coul's Ghost', 259-60; Scott, Fasti, i, 140. 
ministers was the son of Robert Paton, the aforementioned minister whom Sinclair consulted about Coul's ghost. Ogilvie heard of Sinclair's story and discussed it with Paton's son. He expressed his disapproval that (according to his version) Robert Paton had dissuaded Sinclair from meeting with the ghost again. Later he informed some of his brethren that he had himself seen and conversed with the ghost. The matter lay quiet until Ogilvie died in 1729. Then a manuscript account of his dealings with the Laird of Coul's ghost was found in his desk, sealed and with the instruction that it should be opened after his death. It was kept by the family but a copy was made by a printer in Edinburgh named Watkins - presumably Richard Watkins (d. 1747), recognised as one of His Majesty’s Printers from 1741-44 and 1746-7. Upon Watkins's death his friends published the account in 1750 in Newcastle. The first Scottish edition was published in 1751, entitled A Copy of Several Conferences and Meetings, \&c. that Past Betwixt the Reverend Mr. Ogilvie, Late Minister of the Gospel at Innerwick, and the Ghost of Mr. Maxwel Late Laird of Cool. ${ }^{111}$

Ogilvie's encounters with Coul supposedly took place soon after Sinclair's, although there is some confusion regarding dates. Some versions of the chap-book give the date of Ogilvie's meetings as February 1722, whereas Sinclair's encounters took place in February 1723. Other editions give a more probable date of 1724. Even 1744 appears. ${ }^{112}$ The actual story, however, is identical in most editions. ${ }^{113}$ On a February evening, Ogilvie was walking home when he heard somebody riding up behind him. Looking back, he saw a horse, and called: 'Who is there?' The answer came: 'The Laird of Coul, be not afraid'. Ogilvie thought that a friend was playing a trick on him, and threw his cane at the apparition, but it passed straight through him. $\mathrm{He}$ dismounted to pick it up, and 'had some Difficulty in mounting again, what by the ramping of my Horse, and what by Reason of a certain Kind of Trembling throughout my whole Joints'. ${ }^{114}$ Coul explained that he knew that Ogilvie had criticised the Dumfries ministers for telling William Sinclair to stay away from him, and so hoped that Ogilvie would be willing to help instead. In response to Ogilvie's

111 Miller, 'Laird of Coul's Ghost', 262-6.

112 See ibid., 266-72 for a bibliography of the various editions.

113 There are minor variations in spelling and sentence structure. Quotations are from the 1892 edition.

114 Ogilvie, Laird O'Coul's Ghost, 12-13. 
trepidation he assured him that 'you are as safe with me, and safer, if safer can be, than when I was alive'. ${ }^{115}$ As in Sinclair's account, they reached a churchyard soon afterwards. Again, Coul did not take kindly to it: 'he broke from me thro' the Churchyard with greater violence, than ever any man on horseback is capable of, and with such a singing and buzzing noise, as put me in greater Disorder, than I was all the Time I was with him'. ${ }^{116}$ However, they soon met again, and Coul explained his affairs. He had cheated the relatives of deceased men by forging discharges of his debts to them, or forging bonds owing to him. He even owed Ogilvie himself 200 Scots pounds. The most pressing case was the injustice he had done to Homer Maxwell, borrowing 2000 merks from him. He had stolen the bond upon Maxwell's death, and Maxwell's nine children were left starving. He wanted Ogilvie to explain these matters to his widow, noting that 'if that were done, I think I would be easie and happy'. Ogilvie objected that he would be thought 'brainsick and mad', while his fellow ministers would insist that the ghost was really the Devil. ${ }^{117} \mathrm{He}$ did, however, take the opportunity to question his ghostly visitor thoroughly regarding the estate of the dead. In defiance of traditional patterns for ghost stories, the chapbook ended without any resolution for the unhappy ghost.

There were some folkloric elements retained in Ogilvie's account. His horse was agitated, a pattern also seen in Sinclair's story, and the ghost appeared only after dark. However, overall Coul became a very different creature. His incorporeality was stressed. He explained that he was not returning in his own body, which was 'in the Grave rotting', but had borrowed 'such a Body as answers me in a Moment, for I can fly as fast as my Soul can do without it'. (His horse, in another echo of the 'ghost as an animal' theme, was his dead tenant Andrew Johnstoun.) ${ }^{118}$ Sinclair's account, on the other hand, had highlighted Coul's similarity to his past self. In Ogilvie's account Coul was no longer violent or diabolic, and the fantastical elements of Sinclair's story were stripped away. In a broad sense, Ogilvie was doing something similar to Wodrow and Sinclair. Coul was converted from a demonic being into a propagandist

115 Ibid., 20-1.

116 Ibid., 17-18.

117 Ibid., 47-53, 63.

118 Ibid., 24. 
for the afterlife. However, as we shall see, Coul's picture of the afterlife was far from orthodox Calvinism, or even the basic Christian message of Wodrow and Sinclair. Ogilvie was not really trying to tell a ghost story, and cared little about the unresolved debts. Coul was a tool through which to make specific theological points.

Some of these points related to angels and demons. Coul explained that 'from Time to Time, there are sent from Heaven Angels to guard and Comfort, and to do other special Services to good People, and even the Spirits of good men departed are employed on that very Errand'. ${ }^{119}$ Men and houses of distinction had guardian angels, as did cities. Demons also attended certain cities and families, but in greater numbers. Ogilvie had a devil attending his family, as devils assiduously courted the ministers. However, he also had a good angel, who had attended him while Coul spoke with him (perhaps explaining why Ogilvie was safer with Coul than Sinclair had been). ${ }^{120}$ The reflections on guardian angels, while unusual in a ghost story, were not hugely controversial. Calvin had written of angels who were 'assigned the guardianship of the human race', although was less comfortable with the idea that individuals had their own angels. ${ }^{121}$ Peter Marshall has shown that in England, both radical and conservative Protestants offered arguments for the existence of guardian angels in the late seventeenth century. ${ }^{122}$ We have seen that Wodrow and Sinclair described ministering angels. The Scottish minister Alexander Wedderburn wrote in 1682 of how guardian angels made journeys from Heaven to Earth as 'messengers for the good of the Elect', while in 1726 the Caledonian Mercury reprinted an article that began with the assertion that 'The Belief of Guardian Angels is not a whimsical or upstart Notion, but may be plainly proved'. ${ }^{123}$ The really unorthodox part of Ogilvie's account was this notion that angels might be accompanied by the souls of

119 Ibid., 32-3.

120 Ibid., 33-43.

121 John Calvin, Calvin: Commentaries, ed. Joseph Haroutunian (London, 1958), 147. See Peter Marshall, 'The Guardian Angel in Protestant England', in Joad Raymond (ed.), Conversations with Angels: Essays Towards a History of Spiritual Communication, 1100-1700 (Basingstoke, 2011).

122 Marshall, 'The Guardian Angel in Protestant England', 309. See also Alexandra Walsham, 'Invisible Helpers: Angelic Intervention in Post-Reformation England', Past \& Present, ccviii (2010), 77-130.

123 Alexander Wedderburn, Heaven upon Earth, Or, The History of the Transfiguration of Jesus Chirst Opened, and Practically Improven in Several Sermons (Edinburgh, 1703), 109; 'From Mist's Weekly Journal, Sept. 3.,' Caledonian Mercury, 12 Sept. 1726, 6111-12. 
the dead. It was on this topic - man's estate after death - that Coul made his most controversial points.

Coul refused to reveal whether he was in a state of happiness, but noted that he had not yet appeared before God or received any judgement from him. Ogilvie reminded him that it was generally believed that a private judgement took place immediately after death, before the Last Judgement. Coul, however, objected:

No such Thing, no such Thing, no Tryal till the last Day: The Heaven which good Men enjoy immediately after Death, consists only in the Serenity of their Thoughts, the Satisfaction of a good Conscience, and the certain Hope they have of an Eternity of Joy when that Day shall come. The Punishment or Hell of the wicked immediately after Death, consists in the dreadful Things of their awakened Conscience, and the Terror of facing the great Judge, and the sensible Apprehensions of eternal Torments ensuing; and this bears still a due Proportion to the Evils they have done, when they were living. ${ }^{124}$

He continued that those who were not truly wicked, but ill-educated and not mindful of 'the Concerns of Eternity', were in a different category to the truly wicked, and were 'not so much under the Load of the Divine Displeasure, as they are out of His Graces and Favours, for you know it is one Thing to be discourted, and quite another Thing to be persecuted with all the Power and Rage of an incensed earthly King'. He finished with the assertion that 'men's Faces in this World are not more various and different, than their Conditions are after Death'. ${ }^{125}$ There was also an implication that Johnstoun was required to serve as Coul's horse because, although distinctions between laird and tenant were done away with after death, he remained on a lower rung in the post-mortem ladder. Ogilvie was dubious, noting that 'some Things you have advanced, seem to contradict the Scriptures, which I shall ever look upon as the infallible Truths of God; for I find by the Parable of Dives and Lazarus, that one was immediately carried up by the Angels to Abraham's Bosom, and the other thrust down to a Place of Torment'. Coul explained that this account was metaphorical, demonstrating that a man could be miserable during his life and happy thereafter, or

124 Ogilvie, Laird O'Coul's Ghost, 25-6.

125 Ibid., 29-30. 
vice versa. ${ }^{126}$

Calvin distinguished Abraham's bosom from Heaven, with the former being a place of rest for the elect before the Last Judgement. ${ }^{127}$ However, over the seventeenth and eighteenth centuries the orthodox position shifted; the consensus became that the dead went directly to Heaven or Hell. As Marshall explains, English reformers were aware that patristic writers had differentiated Heaven and Abraham's bosom, but preferred to use Abraham's Bosom as a synonym for Heaven. ${ }^{128}$ This was also the case in Scotland. We have seen that George Sinclair criticised Descartes for supposedly believing that souls did not progress directly to Heaven or Hell. Sermons and religious texts from the seventeenth and eighteenth centuries almost universally agreed that the soul faced an immediate judgement after death, and proceeded to Abraham's Bosom (Heaven) or Hell. The Covenanter martyr Hugh Mackail (1640/166) preached that angels carried souls to Abraham's Bosom, where they were welcomed to Heaven by Christ. James Durham (1622-58) pleaded with his reader to consider, if he were to die that night, whether he dared appear before God's Tribunal for judgement. On the state of souls he explained: 'The Souls of Believers, especially of Sufferers, are in a most happy Condition after Death, to wit, under the Altar, in Paradise, Abraham's Bosom, with Christ Jesus, \&c'. Robert Fleming wrote simply: 'betwixt [heaven and hell] there is no middle state after death' ${ }^{129}$ Furthermore, in

126 Ibid., 30-1.

127 John Calvin, Calvin's Institutes: A New Compend, ed. Hugh T. Kerr (Louisville, 1989), 123-4. See also John Calvin, 'Psychopannychia', in Thomas F. Torrance (ed.), Tracts and Treatises in Defense of the Reformed Faith, 3 vols. (Grand Rapids, 1958), iii. There are useful discussions in Yosep Kim, The Identity and the Life of the Church: John Calvin's Ecclesiology in the Perspective of His Anthropology (Eugene, 2014), 78-81, and McKeever, 'Ghost in Early Modern Protestant Culture', 94-101.

128 Peter Marshall, "The Map of God's Word": Geographies of the Afterlife in Tudor and Early Stuart England', in Bruce Gordon and Peter Marshall (eds.), The Place of the Dead: Death and Remembrance in Late Medieval and Early Modern Europe (Cambridge, 2000), 121.

129 Hugh Mackail, The Last Publick Sermon, Being a Faithful and Free One, Preached by Mr. Hugh Mackaile (Edinburgh, 1749), 41; James Durham, The Blessedness of the Death of Those That Die in the Lord (Glasgow, 1756), 70; Robert Fleming, The Fulfilling of the Scripture, in Three Parts, reprint of 1681 3rd edn, 2 vols. (Glasgow, 1801), ii, 131. See also James Webster, Select Sermons Preach'd on Several Texts (Edinburgh, 1723), 122; Ralph Erskine, The Happy Congregation: Or, the Great Gathering of the People to Shiloh (Edinburgh, 1726), 34-6; John Willison, A Treatise Concerning the Sanctifying of the Lord's Day (Edinburgh, 1716), 126; William Crawford, Zion's Traveller: Or, the Soul's Progress to Heaven, 2nd edn (Edinburgh, 1743), 117, 127; William Crawford, The Works of the Truly Pious and Learned Mr. William Crawford Late Minister of the Gospel at Wilton, 2 vols. (Edinburgh, 1748), ii, pt. i, 31-2. 
contrast to Coul's vision of the afterlife, no allowances were made for those who had lived and died in ignorance. This was in line with Calvin's division of the world into the godly elect and the reprobates. A gentleman called William Brown expressed the common belief clearly: 'the World is divided but into two parts, the Elect and Reprobate, Believers and Unbelievers... so [Gods Book] suitably assigns a double state, and no more, after it; Namely, happiness and Misery, and both unchangeable and Eternal'. ${ }^{130}$

However, some theologians thought this picture was too stark, and condemned too many souls to damnation. In 1721, the Aberdeen bishop Archibald Campbell (d. 1744) published a work called The Doctrines of the Middle State between Death and the Resurrection, a revised and expanded edition of a work he had first published anonymously in 1713. It asserted that there was a middle state for souls, called Hades, with a variety of mansions. Some souls were inevitably damned, and were sent to the left. Those who repented on their death-beds went to the lower mansions on the right, their fate uncertain. Those who repented earlier but did not have time to establish a fully virtuous life were carried by angels to the right, where they could progress, through a process of 'purgation and purification', to higher mansions. Pure souls travelled directly to the highest mansions, Paradise, to await their progression to Heaven at the Last Judgement. Campbell also argued that Christians should pray for the last three groups of souls. ${ }^{131}$ Compared to the view that souls went directly to Heaven or Hell, Campbell's vision of the afterlife better allowed for ghosts, a point he noted:

And by the way, I desire all those who believe that several Dead People have appeared again, to reconcile these Apparitions to the commonly received Doctrine of a Soul's going streight to the Beatifick Vision, or to Gehenna upon the Death of the Body, for it is not easy for me to conceive, that a Wicked Soul is Released from the proper Hell of Torment, once it is there, nor that a Happy Soul is turned out of Heaven, and banished from the Beatifick Vision, to appear upon Earth again upon any Occasion until the Resurrection. ${ }^{132}$

130 William Brown, Impiety and Superstition Expos'd: A Poetical Essay (Edinburgh, 1710), preface. See also Daniel Campbell, Meditations on Eternity (Glasgow, 1721), 21.

131 Archibald Campbell, The Doctrines of a Middle State between Death and the Resurrection (London, 1721), for example xviii, xx, 57.

132 Ibid., xvii. 
Campbell's call for prayers for the dead reflected an ongoing debate among the Episcopalians. In England in 1716, a dispute had emerged among the Nonjurors, those bishops who had refused to swear loyalty to William and Mary. It centred around certain ceremonies in the Communion Office known as usages: mixing water with the wine in the eucharistic cup; an explicit epiclesis (or invocation of the Holy Ghost) in the prayer of consecration; the prayer of oblation immediately after the prayer of consecration; and - most interestingly for our purposes - prayers for the dead. These had been practices in the first five centuries of Christianity. They were included in the 1549 Book of Common Prayer, but were judged unscriptural and removed from the 1552 and 1662 versions. ${ }^{133}$ The Scottish Book of Common Prayer, controversially imposed in 1637, signified a partial return to the 1549 version, including prayers of oblation and invocation. ${ }^{134}$ The Nonjurors split into two camps, the 'usagers' and the 'non-usagers'. Scottish usagers included the bishops James Gadderar, Archibald Campbell and the aforementioned Ghost Dog of Mause chronicler Thomas Rattray. ${ }^{135}$ Some Scottish Episcopalians adopted the English Prayer Book in the years immediately following the 1707 Union, but it was often altered to bring the Communion Rite in line with the $1549 / 1637$ version. ${ }^{136}$ The 1637 Prayer Book was reprinted in 1712, and editions of the Scottish Communion Office were later published separately as 'wee bookies'. The first appeared in 1722, and reprinted the liturgy as it appeared in the 1637 book. ${ }^{137}$ A 1735 version was even more sympathetic towards the usages, placing particular emphasis on oblation and

133 Bryan D. Spinks, Liturgy in the Age of Reason: Worship and Sacraments in England and Scotland 1662-c.1800 (Farnham, 2008), 120; David J. Kennedy, Eucharistic Sacramentality in an Ecumenical Context (Farnham, 2013), 52-4; Matthew M. Davis, "“Ask for the Old Paths": Johnson and the Nonjurors', in J. C. D. Clark and Howard Erskine-Hill (eds.), The Politics of Samuel Johnson (Basingstoke, 2012), 113-17.

134 Charles Hefling, 'Scotland: Episcopalians and Nonjurors', in Charles Hefling and Cynthia Shattuck (eds.), The Oxford Guide to The Book of Common Prayer: A Worldwide Survey (Oxford, 2006), 166-8, 171, 173.

135 For discussion of the usages controversy in Scotland, see Kieran German, 'Aberdeen, Aberdeenshire and Jacobitism in the North-East of Scotland, 1688-1750' (University of Aberdeen $\mathrm{PhD}$ thesis, 2010), 83-103.

136 Spinks, Liturgy in the Age of Reason, 126-7; Hefling, 'Scotland', 169.

137 Kennedy, Eucharistic Sacramentality, 54-5; Alasdair Raffe, 'Presbyterians and Episcopalians: The Formation of Confessional Cultures in Scotland, 1660-1715', English Historical Review, cxxv (2010), 596; Raffe, Culture of Controversy, 51, 142-8. 
prayers for the dead. ${ }^{138}$ The usages thus gradually filtered into mainstream Episcopalian culture. In 1723 the Scottish College of Bishops ordered all Episcopalian ministers to sign a declaration stating that they did not support the usages. Bishop James Raitt of Dundee would not sign, and in 1727 became embroiled in a dispute with his joint incumbent, Bishop John Ochterlony, over the usages. He removed with his followers, and formed a separate congregation. Ochterlony died in 1742, and his congregation repudiated the authority of Raitt in 1743 over the issue of the usages. ${ }^{139}$

The usagers were by no means all supporters of a Protestant purgatory like Campbell's, but the notion of prayers for the dead was often perceived as being wrapped up with a belief in an intermediate state. Church of Scotland minister John Willison lamented in 1744:

Ah, how wofully have [the Episcopal clergy] degenerated from the Principles and Practice of their Fathers! ... being strongly attached to Jacobite Principles and a Popish Pretender, they were thereby induced to entertain favourable Thoughts of other Popish Superstitions and Errors, which at length many of them began to vent and stand up for; such as, A middle State for Souls after Death, and Prayers for the Dead. ${ }^{140}$

In 1743, with an eye on the Raitt affair in Dundee, the Episcopalian minister James Dundass wrote a tract underlining that the ancients' belief in Abraham's Bosom, Paradise or Hades as a stepping stone to Heaven was unscriptural, and that biblical references to 'the Bosom of Abraham' meant only Heaven. Raitt retorted that the intermediate state had always been taught by the best Reformed divines. ${ }^{141}$ The debate raged on over the following years. Raitt and Campbell were accused of trying to bring back Purgatory. ${ }^{142}$ In 1744, Thomas Rattray's The Ancient Liturgy of the

138 Hefling, 'Scotland', 172.

139 James Dundass, An Impartial Enquiry into the Rise and Progress of the Ancient Usage of Prayers for the Dead (Edinburgh, 1743), 43-4; The Antiquated Usages, Which Have Made so Great a Noise amongst Us, Briefly Examined, and Found Insufficient (Edinburgh, 1728), 21-6; David M. Bertie, Scottish Episcopal Clergy, 1689-2000 (Edinburgh, 2000), 552.

140 John Willison, A Fair and Impartial Testimony: Essayed in Name of a Number of Ministers, Elders, and Christian People of the Church of Scotland (Edinburgh, 1744), 98.

141 Dundass, Impartial Enquiry, for example 17; James Raitt, An Instructed Historical Account of the Settlement in the Episcopal Congregation of Dundee in 1727 ([Edinburgh?], 1744), 45.

142 See Gentlemen of the Seagate Congregation, A True Narrative of the Case between the Episcopal 
Church of Jerusalem was posthumously published, asserting that 'Prayers for the Dead ... is so very early a Practice of the primitive Church, that undoubtedly it must have been derived from apostolical Tradition ... It is founded on that plain ScriptureDoctrine of an intermediate State betwixt Death and the Resurrection' ${ }^{143}$ Rattray also wrote a longer tract on the intermediate state, in the form of an unpublished letter. Like Campbell, he identified this middle state as Hades, and suggested that it contained a number of mansions for housing departed souls. He explained that 'the Remains of our evil Habits ... must be purged off after Death', and that there was consequently a 'Progressive Advancement, in the after state'. He also noted that 'haunting of Tombs' could be explained by the idea that dead souls remained attached to their old habits, and therefore desired to enter human bodies. ${ }^{144}$

When Ogilvie's account of the Laird of Coul's ghost was written in the 1720s, and again when it was published in 1751, it was thus tapping into a vibrant contemporary debate. Similarly, Thomas Rattray probably took a particular interest in the Ghost Dog of Mause because it suggested that there was an intermediate state, and that souls could be assisted by the living after death. Of course, as a Church of Scotland minister, Ogilvie should not have been advocating a middle state for souls, which is probably why he specified that the account should only be published after his death. Perhaps it also explains why he made use of the Laird of Coul's ghost in the first place, putting the explanation in the mouth of the ghost, and presenting himself as the proper Presbyterian minister objecting that Coul's views were unscriptural. Ghost stories could be used to promote a particular theological argument without having to espouse it officially. This was not, admittedly, a common approach. Ghosts remained uncomfortable territory for Presbyterians. Episcopalians were more likely to have sympathy for the notion of an intermediate state for souls, but it was a contested issue, and Rattray's interest in hauntings was unusual. Nevertheless, the fact that

Congregation of the Seagate of Dundee, on the One Part; and Bishop Raitt with the Reverend Mr. William Robertson, on the Other (Edinburgh, 1745), esp. 47-8; John Glas, A View of the Heresy of Aerius (Edinburgh, 1745), 42-55.

143 Thomas Rattray, The Ancient Liturgy of the Church of Jerusalem (London, 1744), 119n.

144 Thomas Rattray, letter on the intermediate state, n.d.: Special Collections, University of St Andrews, MS Dep. 19/14/1, 44-5, 37. This manuscript was located by Douglas Kornahrens: Wallace Douglas Kornahrens, 'Eucharistic Doctrine in Scottish Episcopacy, 1620-1875' (University of St. Andrews PhD thesis, 2008), 111. 
ghosts might be used to advance theological arguments underlines how much more respectable they had become over the late seventeenth and early eighteenth centuries.

\section{The Decline of the Religious Ghost?}

In England, the rehabilitation of ghosts is associated primarily with the late seventeenth and early eighteenth centuries. As the eighteenth century progressed, the climate changed. Owen Davies explains that the rise of Methodism meant that ghosts 'ceased to act as an ecumenical glue for factions within the Church of England' by the late 1730s. Ghost belief became linked to the Methodists, and as such 'became synonymous with pernicious religious enthusiasm'. ${ }^{145}$ The Scottish religious scene was also fragmented, but ghost belief was not confessionalised in the same way. The impact of Methodism in Scotland was limited, and despite Rattray's interest in ghosts, they do not seem to have become particularly associated with Episcopalian culture. Nonetheless, the religious climate in late eighteenth-century Scotland was also not very amenable to ghosts. From about the 1760 s the dominant faction within the kirk was Moderatism. The Moderates were closely associated with the Scottish Enlightenment, and tended to be critical of religious enthusiasm. ${ }^{146}$ At first glance, the Episcopalian church was more promising. Prayer for the dead was included in the officially authorised 1764 Scottish Communion Office, and the notion of an intermediate state drew more converts - including John Skinner, primus of the Episcopal Church from 1788 to $1816 .{ }^{147}$ However, Episcopalians' discussions of an intermediate state did not tend to reference ghosts. The bishop George Innes (17171781) wrote a manuscript tract asserting the reality of an intermediate state, but also argued that 'no mere man ever came from [after death] to give us information: none but Christ, who is both God and man'. ${ }^{148}$

145 Davies, Haunted, 122. Although see also Handley, Visions of an Unseen World, 140-76, which argues that ghost stories remained relevant across confessional divides.

146 See, for example, Sher, Church and University.

147 For example, John Skinner, A Course of Lectures, Delivered on the Six Sundays in Lent (Aberdeen, 1786), 44-5.

148 George Innes, The Primitive Doctrine: A Middle State of Happiness or Misery between Death and the Resurrection, n.d.: NRS, CH12/21/10; George Innes, Fourteen Discourses on Practical Subjects (London, 1783), 10. 
Nevertheless, on occasion ghosts were still used to make religious points. While the Laird of Coul's ghost delivered controversial theological teachings, this was not why it was remembered. The chapbook circulated widely. The introduction to the 1892 version states that it was 'eagerly bought by all and sundry from the Flying Stationers who hawked it about the country'. ${ }^{149}$ Frank Miller has identified nine editions from the eighteenth century and fifteen to seventeen from the nineteenth century. ${ }^{150}$ The Laird of Coul became probably Scotland's most famous ghost; certainly no other ghost stories were reprinted so frequently. This was almost certainly despite, rather than because of, its precise religious message. In the $1770 \mathrm{~s}$ there was a debate in the Edinburgh Weekly Magazine about whether or not ghosts existed. One man, going under the pseudonym C. G., declared:

the story of Maxwell of Cule's re-appearance soon after death ... was a most nottour and flaming story not many years ago, and he continued to fright many for some time, till at last he found one Mr Ogilvie ... who had the courage to hold sundry conversations with his re-appearance, and to write down a number of particular facts and circumstances, which were printed, published, and sold in the streets of this, and sundry other market towns in Scotland, England, and Ireland.

C. G. argued that the story was factual, and that a 'good and instructive moral' could be drawn from it. ${ }^{151}$ 'Fabricius' replied a month later, retorting that the Laird of Coul 'must have been the production of some shallow scribbler, with some small degree of sheer wit; for it represents a minister holding conferences with a ghost that are trifling and ridiculous'. ${ }^{152}$ These men took little interest in the specific theological debates underpinning the story; they were mainly concerned with whether or not Coul proved the reality of ghosts. C.G. presented Ogilvie as a brave minister who brought an end to the appearances of the ghost, although as we have seen, Ogilvie actually made no attempt whatsoever to play this part. Coul lingered in Scottish culture not as a spokesperson for an intermediate state, but simply as a famous ghost, presenting a general moral and religious message. As in the case of Wodrow's and

149 J. F. S. Gordon, 'Introit', in William Ogilvie, The Laird O'Coul's Ghost (London, 1892), vi-vii.

150 Miller, 'Laird of Coul's Ghost', 266-72.

151 C. G. to the Weekly Magazine, or Edinburgh Amusement, 16 Apr. 1772, 74.

152 Fabricius to the Weekly Magazine, or Edinburgh Amusement, 7 May 1772, 167. 
Sinclair's ghosts, unorthodox theological points were ignored.

Believers in an intermediate state might be more receptive to the story's precise messages, but even then they were often downplayed. Miller writes that the founder of Methodism, John Wesley (1703-91), gave the story a broader circulation among educated audiences when he printed it in his Arminian Magazine in 1785. ${ }^{153}$ Wesley was interested in ghosts, evil spirits, and guardian angels, and leant towards believing in an intermediate state. ${ }^{154}$ However, he did not advertise this latter belief. He noted apologetically at one point in the story that 'I am afraid this glances upon Purgatory', and added at the end that he did not understand everything in the account. ${ }^{155}$ The implication was that he was reprinting the story more for its general religious points than as propaganda for an intermediate state. Also in 1785 , the story attracted the attention of Elizabeth Steuart of Coltness (d. 1803), 'Aunt Betty' to the Whig politician Henry Erskine. ${ }^{156}$ Steuart's interest in spirits is indicated in a snippet from a young minister in reply to one of her letters: 'I should esteem it a favour to hear your sentiments more fully respecting those spirits which you say are common at this day. I am by no means disposed to call everything nervous, \&c'. ${ }^{157}$ She was fascinated by the story of Coul's ghost, noting that 'no words could Express what a treasure I thought it' ${ }^{158}$ Alexander Fergusson argues that she was attracted to the doctrine of the Swedish theologian Emanuel Swedenborg, who was influential in the eighteenth century. Swedenborg emphasised the role of angels and spirits in everyday life. He also believed in an intermediate state, the World of Spirits, a half-way house between Heaven and Hell where men were judged after death. Steuart did not uphold Swedenborg's idea that a Last Judgement had already taken place in the World of Spirits, but she was a firm believer in the guardianship of good angels and attendance of evil ones, and also in a middle state for souls. ${ }^{159}$ She wrote:

153 John Wesley, 'A Strange Account', Arminian Magazine, July-Aug. 1785, 378-81, 416-20.

154 Kenneth J. Collins, The Theology of John Wesley: Holy Love and the Shape of Grace (Nashville, 2007), 318-20.

155 Wesley, 'Strange Account', 381, 420.

156 Alexander Fergusson, The Honourable Henry Erskine, Lord Advocate for Scotland (Edinburgh, 1882), 369-87. Sometimes her name is given as Elizabeth Steuart-Barclay.

157 Ibid., 374-5.

158 Elizabeth Steuart-Barclay, papers on the Laird of Coul's Ghost, 1788-1802: NLS, MS. 10785.

159 Fergusson, Honourable Henry Erskine, 383. On Swedenborg see Ernst Benz, Emanuel Swedenborg: Visionary Savant in the Age of Reason, trans. Nicholas Goodrick-Clarke (West 
It is long since I was convinced, that our seperated stat, first on our Death, is like the purgatory of the Roman Catholics; all who die goes down to the infancy of these Invisible Elements, that worked in our vessels, when alive, \& produced, all our words \& thought $\&$ action. In these Invisible Elements, we are taught, purified \& Educated, \& made fit, to act our part in the new heavens \& the new Earth; \& there we mount through the various stages of Government \& be made angels \& minestrating spirits, to Christ, who has under taken the redemption, of the world. ${ }^{160}$

Regarding Coul's ghost, however, Steuart explained: 'I use not this good and just apology setting forth Cool in the hand of God, to explain to mankind the Laws of a seperate state'. Instead, she wanted to use the story to show the importance of securing God's forgiveness before death. She wrote to Ogilvie's daughter Henrietta, arguing that the story should be re-published, supplemented with her commentary. Henrietta refused. She wrote that although she believed the story herself, she was frightened of marring her father's character. She worried that people would attack him for 'weakness and credulity', and that 'heaven and earth would [be] called on' to disprove the story. She added that the chap-book had been 'hackney'd about \& despised'. Steuart circulated her commentary among friends instead, and her nephew published the work by her instructions in 1808, after both she and Henrietta had died. ${ }^{161}$ The interest of C. G., Wesley and Steuart demonstrates the resilience and flexibility of the religious ghost. Again, Coul's apparition was useful for making general religious arguments, regardless of its more controversial theological messages.

Similarly, Satan's Invisible World Discovered was reprinted frequently in the late eighteenth century, without the anti-Cartesian preface, but still with the overarching purpose of refuting atheists. ${ }^{162}$ Other collections of this type were also produced. In 1763, a Skye minister published A Treatise on the Second Sight, Dreams and

Chester, 2002).

160 Elizabeth Steuart-Barclay, papers on the Laird of Coul's Ghost, 1788-1802: NLS, MS. 10786.

161 Fergusson, Honourable Henry Erskine, 379, 383-5; William Ogilvie, Narrative of Four Conferences Between the Ghost of Mr. Maxwell, of Coul, and the Rev. Mr. Ogilvie, Minister of Innerwick, ed. Elizabeth Steuart (London, 1808).

162 For a list of editions see Coleman O. Parsons, 'Introduction', in George Sinclair, Satan 's Invisible World Discovered (Gainesville, 1969), xxv-xxviii. 
Apparitions: With Several Instances Sufficiently Attested, under the pseudonym Theophilus Insulanus. ${ }^{163}$ Insulanus primarily discussed second sight, but also included some ghost stories. His goal was to prove the reality of spirits, and most of his ghosts returned to confirm the reality of the afterlife. Around 1775 The History of Witches, Ghosts and Highland Seers was published, not quite in Scotland, but nearby in Berwick. It likewise focused primarily on second sight, and was 'Designed For the Conviction of the Unbeliever'. ${ }^{164}$ There was also a cluster of collections published in the late eighteenth century in London, containing Scottish stories: The Compleat Wizzard: Being a Collection of Authentic and Entertaining Narratives of the Real Existence and Appearance of Ghosts, Demons, and Spectres (1770), Visits from the World of Spirits: Or, Interesting Anecdotes of the Dead (1791), and Malcolm Macleod's History of Witches \&c (1793). The latter, for example, told a pair of interesting stories from Scotland. Both concerned a young man called Thomas Lilly, who was visited by the spirit of his grandfather. The first time the ghost warned him of poison in his broth; the second time he directed him to buried treasure. The collection also contained a wraith story. ${ }^{165}$

This is not to say that nothing had changed compared to the late seventeenth and early eighteenth centuries. When Satan's Invisible World Discovered was originally published its preface tied it into a contemporary philosophical debate, while the references to Glanvill established it within a broader framework of natural philosophers investigating the supernatural for scientific and religious reasons. It did not initially reach a mass popular audience. Archibald Pitcairne's 1692 play The Assembly hints at its early readership. Pitcairne presents it as part of the library of a strict old Presbyterian lady. While the heroes of the play are disguised as Presbyterian ministers in an endeavour to woo the lady's nieces, she tells them of the books she has bought: 'Ther's Dickson's Sermons. Ther's 11 Pynts to Bind up a

163 The identity of Theophilus Insulanus remains unclear. Most recent works give the name Donald MacLeod/McLeod (see, for example, Hunter, Occult Laboratory, 40); this is also the name given in John MacCulloch, The Highlands and Western Isles of Scotland, 4 vols. (London, 1824), iv, 63. Genealogies of the MacLeod family give, instead, William MacLeod. See Donald MacKinnon and Alick Morrison, The MacLeods: The Genealogy of a Clan, 5 vols. (Edinburgh, 1968-76), ii, 111.

164 The History of Witches, Ghosts, and Highland Seers (Berwick, [1775?]), title page.

165 Malcolm Macleod, History of Witches \&c (London, 1793), 39-42, 42-4, 33-4. 
Beleiver's Breeches. Ther's Bessie of Lanerk. Ther's Saml. Rutherford's Letters. Ther's Good News from Heavn. And ther's Satan's Invisible World. What think you, Mr John, of Satan's Invisible World?' 'Mr John', being in fact a young man 'not weall seen in divinity', has not heard of the work, and guesses wrongly when he replies that it is 'the best Sermon evr I heard'. ${ }^{166}$ However, while the work may have originally reached only a niche audience, by the late eighteenth century it seems to have been well known; Christina Larner suggests that it became the 'second book in a peasant's library of two'. ${ }^{167}$ The expansion of cheap print culture and literacy rates over the eighteenth century contributed to the increasing popularity of ghost stories as a genre. It is probable that while Sinclair's work was originally aimed at an elite audience, its later editions and the similar collections that emerged were targeted at the popular market. Although these collections were still justified through religious arguments, they were no longer linked to an ongoing intellectual debate.

However, this does not mean that the religious justifications were insincere. Theophilus Insulanus approached his subject with all Sinclair's anxiety about the dangers of materialist world-views. In the dedication to A Treatise on the Second Sight, he noted that he was writing at a time when 'the pulpit resounds with repeated exclamations against the infidelity of the age, when vice reigns triumphant, and atheism, or at least deistical principles are openly avowed, and by too many much countenanced'. ${ }^{168} \mathrm{He}$ acknowledged that people of 'weak intellects' might become superstitious 'by a studious and too eager attention to revelation, by dreams, Second Sight, and other kinds of divination'. However, he thought it better that people should give way to superstition, as it would 'settle in the mind an awful sense of the essentials of religion', than that they should follow in the footsteps of deists and freethinkers. ${ }^{169}$ In a curious turnaround from the general position in the wake of the Reformation, Insulanus argued that it was un-Protestant to discourage the laity from

166 Archibald Pitcairne, The Phanaticks, ed. John MacQueen (Woodbridge, 2012), act v, scene ii, 11. 44-8, p. 62; p. 5 (Dramatis Personae).

167 Christina Larner, Enemies of God: The Witch-Hunt in Scotland (London, 1981), 32; see Parsons, 'Introduction', xxv.

168 Theophilus Insulanus, A Treatise on the Second Sight, Dreams and Apparitions (Edinburgh, 1763), dedication.

169 Ibid., xvii-xviii. 
taking an interest in apparitions: it was akin to the Catholic belief that the laity should not read the Bible themselves because they might misinterpret it. ${ }^{170} \mathrm{He}$ also noted that some fellow ministers owned the reality of second sight and apparitions, but doubted whether the intelligence came 'from the ministry of good or bad spirits'. He countered this by arguing that second sight had "no tendency to instil bad morals or promote infidelity', and it was therefore much more likely to be divinely inspired. ${ }^{171} \mathrm{He}$ conjectured that God sent 'beneficient spirits' to communicate second sight to men's souls. The aim was 'to awaken us from the daliance and short pleasure of sin', as 'From the certainty of dreams, Second Sight, and apparitions, follows the plain and natural consequence of the existence of spirits, immateriality and immortality of the soul'. ${ }^{172}$

The years 1790-1 saw the publication of a collection of sermons by Edinburgh minister John Logan (1748-88). These sermons included a commentary on the story of the rich man and Lazarus. ${ }^{173}$ In the story, the rich man begs Abraham to send Lazarus to his five brothers to warn them of the torments of Hell, declaring that 'if one went unto them from the dead, they will repent'. Abraham replies: 'If they hear not Moses and the Prophets, neither will they be persuaded though one rose from the dead'. ${ }^{174}$ Commenting on the last point, Logan explained:

Let us suppose, that in order to convince a person of the immortality of his soul, Almighty God sent one of his deceased friends, either in his unembodied state, or with the same body he had in life. As no person would require such a proof, but one who was very much addicted to scepticism, it is very probable, that even then his doubts would not be removed. He might say, perhaps this may be an impostor, perhaps it may be some evil spirit who has assumed the shape of my deceased friend. ${ }^{175}$

It is interesting to note that while Logan acknowledged the demonic interpretation of apparitions, he was not very sympathetic towards it. Far from being a prudent and

170 Ibid., 119.

171 Ibid., 122-3.

172 Ibid., 123, 44.

173 John Logan, Sermons by the Late Reverend John Logan, 2 vols. (Edinburgh, 1790-1), ii, 50-2.

174 Luke 16:19-31. Version given in ibid., 50.

175 Ibid. 
pious consideration, it was the result of an 'addiction' to scepticism. Logan invited his reader to imagine that this sceptic were subsequently convinced 'of the reality of the apparition, and the truth of a future state': belief in the ghost was equated, in the fashion of Sinclair, with belief in the afterlife. Logan went on to explain that his sceptic-turned-believer, going into society, would meet with so much derision that he was very likely to resolve that he had been mistaken after all. Even the ghost of Samuel, Logan pointed out, did not long convince Saul to repent of his sins. His conclusion was that 'mankind are not always in a mood to be convinced'. ${ }^{176}$ Logan spoke only in conditional terms and did not argue that God was in fact sending ghosts to perform this service, but he clearly allowed it to be a possibility, and at least implied that the ghost of Samuel was one example.

Finally, we can consider the account of mysterious noises in a house in Stronsay, Orkney, reported by the minister John Anderson. The story featured in the Statistical Account of 1791-99. ${ }^{177}$ It was accompanied with an unusually detailed justification, which is worth quoting in full:

In this eminently enlightened age, when atheism and irreligion have been very active in bringing, not only superstition and enthusiasm, but religion itself to the Guillotine, it is highly probable, that the traits of character now exhibited will be held in derision, and the drawer therof exposed to infinite ridicule on account of the preceding narrative, by those who glory in being superior to vulgar prejudices. If this should be the case, he will not attempt to remonstrate, but only humbly propose the following queries. 1st, Are the inconsiderable remains of superstition and enthusiasm, which do affect the character only in small and unimportant matters; or scepticism, which gives a new and totally different direction to the understanding and the will, least dangerous to our happy establishment in church and state? And whereas the human mind is a fruitful field, in which wholesome herbs, or noxious weeds, will spring up and flourish, -2dly, Is it wiser to pluck up at once the whole existing crop, before we have duly considered the nature and tendency of the seed to be substituted in its place; or to continue to cultivate the seeds of revealed religion, (which system hath been held in high estimation by wise men in all ages of world,) and at the same time, gradually to check and eradicate pernicious errors and immoral practices? A candid examination of these queries may possibly furnish some apology, why the minister and people of this district are not very hasty to exchange old prejudice for new and strange doctrines, which eventually may be, and in a neighbouring nation have been subversive of

176 Ibid., $50-2$.

177 On Anderson see Scott, Fasti, vii, 274. 
the principles of religion natural and revealed. ${ }^{178}$

This explanation was, in part, a product of Anderson's climate. The 1789 French Revolution was associated with atheism, as can be seen in the idea that 'religion itself' was brought 'to the Guillotine'. While the political situation in Scotland did not escalate as it had in France, the early years of the decade in particular saw a wave of radicalism across the country. Anderson was writing in 1794, when anti-French feeling was exacerbated by war and the excesses of the Reign of Terror. ${ }^{179}$ It was therefore a time when clergymen were particularly keen to defend 'our happy establishment in church and state'. Ghosts were also used to this end in pamphlet literature, with dead revolutionaries returning to bemoan the evils of civil disobedience. ${ }^{180}$ However, although Anderson's account reflected the contemporary political context, his basic message was nothing novel. Of course, he distanced himself from the 'old prejudice' he was defending, just as Insulanus hid behind a pseudonym and Logan did not actually suggest that ghosts were making appearances on earth. All three authors were thus more cautious than Wodrow and Sinclair. Nevertheless, they all reprised Wodrow and Sinclair's idea that atheism was a greater threat to the kirk than excessive credulity, and all seemed prepared to take a (relatively) sympathetic view of apparition stories as a result. Overall, although the religious ghost may never have made its way into mainstream religious culture, there is evidence that it retained a place on the sidelines throughout the eighteenth century.

178 John Anderson, 'United Parishes of Stronsay and Eday', in John Sinclair (ed.), The Statistical Account of Scotland, 1791-1799, electronic edn, 21 vols. (University of Edinburgh, University of Glasgow, 1999), xv, http://stat-acc-scot.edina.ac.uk/link/1791-99/Orkney/Stronsay\%20and\%20 Eday, accessed 1 Aug. 2015, 432.

179 On radicalism see, for example, T. M. Devine, 'The Failure of Radical Reform in Scotland in the Late Eighteenth Century', in T. M. Devine (ed.), Conflict and Stability in Scottish Society, 1700 1850 (Edinburgh, 1990). The dating of Anderson's passage is from Anderson, 'United Parishes of Stronsay and Eday', 398.

180 See Brissot's Ghost! Or, Intelligence from the Other World (Edinburgh, 1794); An Account of a Most Horrid, Bloody, and Terrible Apparition, Which Lately Appeared in the Parish of Shotts (London, 1793). The ghosts of pamphlet literature are discussed on pp. 200-9. 


\section{Conclusion}

From the late seventeenth century, ghosts took on a more important role in Scottish society. The emergence of atheism as a comparable threat to enthusiasm and Catholicism resulted in some Protestants taking a new interest in the returning dead. Scotland's movement towards reclaiming ghosts was not on the same scale as England's, and ghosts never became 'entirely respectable' as Newton and Bath argue regarding England. The religious context in the late seventeenth and early eighteenth centuries was rather too strained in Scotland, with accusations of enthusiasm being a more acute threat than they were in England (at least prior to the rise of Methodism). However, Wodrow and Sinclair were respectable Presbyterians who collected stories from other educated folk. Although they were not representative of the kirk as a whole, their interest indicates that ghosts had become marginally more acceptable. The growing fear of atheism is not the only explanation for this. Increased research into folkloric beliefs also slotted into a context of broadening geographical awareness, scientific investigation and nation-building. ${ }^{181}$ Nonetheless, the primary function of the stories was to make religious points. Apparitions were increasingly depicted in a positive light. Hostile revenants were still presented as demonic, but they did not crop up very frequently, and were counterbalanced by stories about corpses resurrected by God to deliver useful messages. There was also a resurgence of stories about ministering angels. Ghosts were presented as having come from God, and demonstrated the reality of spirits and the afterlife. Beyond this, however, they showed a good deal of theological flexibility. Stories were seemingly taken from popular culture, and were not completely purged of their medieval themes. This suggests that we should not over-emphasise the growth of 'theological rigidity' in the late seventeenth and early eighteenth centuries. Theological messages were adjusted for their specific audiences. When it came to addressing atheists these messages could justifiably be broad.

Ghost stories could also be harnessed to reflect on particular theological debates. For Thomas Rattray and William Ogilvie, ghosts could be used as propagandists for an 181 See pp. 181-3. 
intermediate state. However, the Laird of Coul's precise theological points were later downplayed; the story was promoted for its more general religious messages. Its popularity within cheap print culture probably owed little, if anything, to its religious teachings, but a worthy moral message furnished a good excuse to print stories in the lucrative genre of the supernatural. Commercial considerations doubtless factored into to the many editions of Satan's Invisible World Discovered and similar collections printed in the latter half of the eighteenth century. However, there remained a strand of educated folk who genuinely considered ghosts to be a useful defence against atheism, in the context of developments in Enlightenment thought and the French Revolution. By the nineteenth century, ghosts were still described as having a 'higher moral purpose'. ${ }^{1}{ }^{12}$ While the religious ghost did not exactly flourish, it did survive, despite the influence of Moderatism. Ghosts had become morally defensible, which cleared the way for the expansion of ghost stories and ghostlore more generally over the eighteenth century.

182 'The Voyages And Travels Of Columbus Secundus', Blackwood's Edinburgh Magazine, Nov. 1821, 399; see also Anne MacVicar Grant, Essays on the Superstitions of the Highlanders of Scotland, 2 vols. (London, 1811), i, 114-15. 


\section{Chapter Three}

\section{Scepticism and Debate}

It has long been argued that the supernatural declined in importance in eighteenth century Britain. The witch trials came to an end. Psychological explanations for apparitions became fashionable as physicians and philosophers developed new theories about the workings of the mind. David Hume wrote a sceptical essay on miracles that stands as an important milestone in the history of philosophical debate on the supernatural. As we have seen, Keith Thomas associates the Enlightenment with a Weberian disenchantment of the world, arguing that ghosts progressively lost their 'social relevance' in the light of scientific developments and changing attitudes towards the dead. Thomas's focus is on England, but similar arguments have been applied to Scotland, if not specifically to Scottish ghosts: we can recall that Paul Kléber Monod credits the Scottish Enlightenment and the Scottish kirk with '[shaking] off the occult'. ${ }^{1}$ This chapter will consider the clash between ghosts and this much-vaunted Enlightenment rationalism. New brands of scepticism emerged in the eighteenth century, while the expansion of print culture offered new venues for ghosts to be debated and satirised. To what extent did this change the place of ghosts in Scottish society?

\section{The Demonic Interpretation}

In the late seventeenth and early eighteenth centuries, the primary way to discredit ghosts was to recast them as demons, just as James VI had. John Robertson noted in 1694 that 'the Presbyterians believe that any such apparitions [of the returning dead] are but Devils assuming the body, or the shape of the dead'. ${ }^{2}$ In 1720, William Cheyn published a work entitled The Great Danger and Vanity or Folly of Atheism Discovered. He offered a series of defences against atheism, framed as a dialogue

1 On Thomas see p. 2. Paul Kléber Monod, Solomon's Secret Arts: The Occult in the Age of Enlightenment (New Haven, 2013), 346. See p. 6.

2 John Robertson, Rusticus Ad Clericum, Or, The Plow-Man Rebuking the Priest in Answer to Verus Patroclus ([Aberdeen?], 1694), 89. 
between an atheist and a believer. One of his evidences was 'the Being of Spirits in general, and of evil Spirits in particular'. He explained that good spirits could appear to men, but did so only on 'very great and pressing Calls and Necessity's', and required a commission from God to do so. Evil spirits, on the other hand, required only God's permission, and came frequently 'from mischievous Designs'. By 'evil spirits' Cheyn meant demons: he clarified that they were fallen angels. These demons were incorporeal, but had the power to assume a dead body. ${ }^{3}$ Cheyn had his atheist explain that some people saw armies in the air, and 'some have professed themselves to have truely and really seen and beheld these appearances, which are ordinarily Termed Ghosts, representing Persons sometimes who are then Living, sometimes such as are already Dead'. However, people also claimed to have seen 'water-wraths', creatures whose appearance or cries foreshadowed deaths near the bodies of water they inhabited; 'elf-bulls', which impregnated cows; and fairies. The atheist concluded: 'And therefore such appearances of Body's, whither Dead or Alive, is a very Weak (if any way worthy to be called a) Testimony of such pretended evil Spirits, as are made the Subject of this argument'. The atheist's position, then, was that ghosts were merely a vulgar superstition, an idea that would recur frequently as the eighteenth century progressed.

The believer responded with an acknowledgement that many of these things 'may appear meerly like Old Wives Fables'. ${ }^{4}$ He drew no conclusions as to the truth or otherwise of the stories, but noted that if ghosts and other apparitions 'be not true and reall Spirits (either by the speciall Commission or Permission of GOD) assumeing these aeriall Body's', they still demonstrated the power of God, who made the appearance of spirits. ${ }^{5}$ Cheyn also noted that evil spirits had haunted places and houses in 'fearfull and terrifying manner'. ${ }^{6}$ In short, he allowed that the dead might return, but still leant towards ascribing hauntings to demons, considering both options to be equally useful in proving the reality of God. This approach lost ground over the decades that followed. Psychological explanations for apparitions

3 William Cheyn, The Great Danger and Vanity or Folly of Atheism Discovered in a Dialogue between an Atheist and a Believer (Edinburgh, 1720), 119, 120-1, 125-6.

4 Ibid., 151-2.

5 Ibid., 153-4.

6 Ibid., 159; see also 102-3. 
challenged Cheyn's conclusion that, if apparitions were not genuine spirits, they must still be conjured by God. Interest in the machinations of demons waned as the witch trials died out: the last Scottish prosecution was in 1727, and witchcraft was decriminalised in 1736. The demonic interpretation never completely disappeared, but scepticism was increasingly framed in new ways. This was in part the result of a changing intellectual climate.

\section{The Supernatural and the Enlightenment}

In its broadest sense, the supernatural remained topical throughout the eighteenth century. Special providences fell out of fashion, but the guiding hand of general providence retained a central place in theological thinking. Francis Hutcheson underlined its importance. ${ }^{7}$ William Robertson wrote of how 'The Supreme Being conducteth all his operations by general laws', identifying John Knox as a providential tool for advancing the Reformation, while Adam Ferguson declared that 'it is joyous to live and it is a triumph to die' in a world governed by a wise and benevolent providence. ${ }^{8}$ Meanwhile, there was lively debate over the credibility of miracles, and the question of whether religious belief should be confirmed by reason or supernatural revelation. As we have seen, deists and other radical philosophers adopted a sceptical stance on miracles in the late seventeenth and early eighteenth centuries. In 1730 the reverend Archibald Campbell attacked Thomas Woolston for doubting the resurrection of Christ. Campbell argued that the apostles were disillusioned with Christ by the time of the Resurrection, and therefore had no motive to spread false stories of miracles (an idea that met with stern disapproval from the General Assembly). He noted that the Apostles claimed to be 'animated by an impulse supernaturally communicated to their minds', and to be ordered by Heaven to preach the Gospel. He continued: 'That the Apostles made good their

7 Francis Hutcheson, A System of Moral Philosophy, in Three Books, 2 vols. (Glasgow, 1755), for example i, 131, 209-20; ii, 377.

8 Colin Kidd, 'The Scottish Enlightenment and the Supernatural', in Lizanne Henderson (ed.), Fantastical Imaginations: The Supernatural in Scottish History and Culture (Edinburgh, 2009), 106; Richard B. Sher, Church and University in the Scottish Enlightenment: The Moderate Literati of Edinburgh (Edinburgh, 1985), 102. 
commission, is fully evident to me from those Miracles they wrought'. ${ }^{9}$

Further defences of miracles emerged in response to David Hume, who famously attacked miracles as part of his An Enquiry Concerning Human Understanding (1748). Hume defined a miracle as 'a transgression of a law of nature by a particular volition of the Deity, or by the interposition of some invisible agent'. However, the laws of nature were confirmed by long experience. When confronted with the story of a miracle, Hume explained, he would always ask himself whether it were more likely that these long-established laws should have been violated, or that the percipient of the miracle was a fool, a liar, or mistaken. Provocatively for the kirk, he took the example of a dead man returning to life, which 'has never been observed, in any age or country'. ${ }^{10} \mathrm{He}$ declared that there was insufficient evidence to claim that any miracle had ever taken place, and that 'a miracle can never be proved, so as to be the foundation of a system of religion'. ${ }^{11}$

George Campbell's 1762 Dissertation on Miracles was the foremost critical response to emerge from Scotland. Campbell used a common-sense approach to defend miracles, criticising Hume's focus on testimony as making it impossible for a human being to believe in anything that he had not directly experienced. Thomas Reid, James Beattie and Alexander Gerard similarly opposed Hume (although not on miracles specifically) from a common-sense standpoint. Scripture-based defences for miracles also emerged. ${ }^{12}$ When Alexander Gerard published a book on evidences for miracles in 1766 , he declared that 'it will be difficult to name a subject that has oftener been canvassed'. ${ }^{13}$ By the end of the eighteenth century, miracles were still

9 Archibald Campbell, A Discourse Proving That the Apostles Were No Enthusiasts (London, 1730), xv.

10 David Hume, 'An Enquiry Concerning Human Understanding', in Mark C. Rooks (ed.), The Complete Works and Correspondence of David Hume, electronic edn (Charlottesville, 1995), http://pm.nlx.com/xtf/view?docId=hume/hume.00.xml;chunk.id=div.hume.pmpreface. 1 ;toc. depth=2;toc.id=div.hume.pmpreface. 1 ; hit.rank=0; brand $=$ default, accessed 1 Aug. 2015, sec. 10, pt. i, 114.

11 Ibid., sec. 10, pt. ii, 127.

12 M. A. Stewart, 'The Early British Reception of Hume's Writings', in Peter Jones (ed.), The Reception of David Hume In Europe (London, 2005), 30-42.

13 Friedhelm Voges, 'Moderate and Evangelical Thinking in the Later Eighteenth Century: Differences and Shared Attitudes', Records of the Scottish Church History Society, xxii (1985), 149. 
being upheld as the primary proof of God's existence: in 1815 Sir Henry Moncrieff Wellwood asserted that if it were to be supposed that the general doctrine which asserts the existence of miracles is incredible or uncertain ... this would be in truth to suppose that the whole history of Christianity is false or questionable'. ${ }^{14}$ Although Hume's work is rightly taken as a milestone in the development of Enlightenment thinking, the mainstream position remained that miracles had occurred, and could do so again by the grace of God. ${ }^{15}$

Debates on the reality of the soul and the afterlife also flourished during the eighteenth century. Cartesian notions of the body as an automaton lost their radicalism in the face of more extreme materialist frameworks, such as that of French physician Julien Offray de la Mettrie. Writing in 1748, he presented man as a machine and denied that any kind of soul existed independently of the body. ${ }^{16}$ In response, a broad swathe of philosophers argued that the existence of a separate soul could be demonstrated. In Scotland the physicians Robert Whytt, George Cheyne and William Porterfield asserted that a separate soul was necessary for physiological reasons, for example to govern the action of the heart and other vital motions. ${ }^{17}$ Moral arguments were also employed: if God was to be fair, it was necessary for there to be an afterlife where the soul could find recompense for the injustices of life on earth. ${ }^{18}$ These arguments relied on physiology or philosophy, but the Moderates tended to be dubious of the idea that the immortality of the soul or the existence of the afterlife could be proved in this manner. Hugh Blair explained in a published sermon that the belief in an afterlife, while common to all societies, 'sprung not from the refinements of science, or the speculations of philosophy; but from a deeper and stronger root, the natural sentiments of the human heart'. ${ }^{19}$ Supernatural revelation

14 Ibid., 148-9.

15 See Stewart, 'Early British Reception.'

16 Julien Offray de La Mettrie, 'Machine Man', in Ann Thomson (ed.), La Mettrie: Machine Man and Other Writings (Cambridge, 1996).

17 John P. Wright, 'Materialism and the Life Soul in Eighteenth-Century Scottish Physiology', in Paul Wood (ed.), The Scottish Enlightenment: Essays in Reinterpretation (Rochester [Vt.], 2000), 182, 184; John P. Wright, 'Metaphysics and Physiology: Mind, Body and the Animal Economy in 18th-Century Scotland', in M. A. Stewart (ed.), Studies in the Philosophy of the Scottish Enlightenment (Oxford, 1990), 252, 268, 272, 281.

18 See Thomas Ahnert, 'The Soul, Moral Philosophy and Natural Religion in the Scottish Enlightenment', Eighteenth Century Thought, ii (2004), 235-6.

19 Ibid., 343. 
thus retained a role when it came to confirming religious teachings on the soul and afterlife.

On one hand, these debates demonstrate that there was potentially still a place for ghosts within the eschatological framework. So long as miracles and wonders remained a theoretical possibility, it could be argued that the dead might return, because there remained a theological basis for God making direct supernatural intervention in the world. Continued belief in a separate soul was also significant. However, in practice there was little room for ghosts in high Enlightenment theological and philosophical debate. When such a primary tenet of Christianity as miracles was under attack, nobody was going to rush to defend ghosts. Indeed, one author noted that there was a very great difference between the biblical miracles and poorly-attested accounts of prodigies, which he compared to ghost stories. ${ }^{20}$ In addition, debates about miracles and providence were couched in abstract philosophical and theological terms, or in terms of human physiology; there was little place for the empirical arguments drawn from ghosts that can be seen in Sinclair's work. In general terms, the supernatural survived in the religious debates of the Enlightenment. Ghosts did not.

\section{Mental Disorders, Dreams, Enthusiasm, and the 'Prejudices of Education'}

If ghosts were excluded from some aspects of intellectual culture and debate, they found refuge in others. The eighteenth century, particularly the latter half of it, saw a growing interest in the subject of mental disorders. Michel Foucault's 1964 Madness and Civilization: A History of Insanity in the Age of Reason argues that madness was seen as a kind of immorality from the mid seventeenth century up to the late eighteenth and early nineteenth centuries, when the concept of mental illness was invented. There was a rapid growth of asylums and a surge of texts on the subject. ${ }^{21}$

20 A. M., Remarks on Revelation \& Infidelity: Being the Substance of Several Speeches Lately Delivered in a Private Literary Society in Edinburgh (Edinburgh, 1797), 214.

21 See H. C. Erik Midelfort, 'Madness and Civilization in Early Modern Europe: A Reappraisal of 
R. A. Houston notes that in Scotland, 'tutories awarded on the basis that the subject was incompos mentis trebled when we compare the average for the 1710s and 1720s with that for the 1780s to 1810s'. Edinburgh Bedlam opened in 1743, and the 1750s saw surging numbers of people cognosced. ${ }^{22}$ Akihito Suzuki suggests that there was 'no such thing as diseased mind' in British medical writing from about 1600 to 1760 ; madness was a purely bodily ailment. In the latter decades of the eighteenth century the diseased mind 'started to occupy the central place in the medical language of madness'. As theories of dualism and the mind-body relationship developed, philosophers increasingly allowed for a separate mind, not governed by bodily processes. ${ }^{23}$ Suzuki notes that Herman Boerhaave (1668-1738), the Leiden physician whose teachings were adopted in Edinburgh in the early eighteenth century, saw madness as a disease of the body. The body generated a false idea and the mind was tricked into believing it. Boerhaave explained:

It is not the business of the physician to be acquainted with what the mind is, how it passes from one thought to another... Though all these properties of the mind are real, yet is the knowledge of them of no use to the physician, so far as they have no relation to the body: for allowing him to be acquainted with all these particulars, and supposing that he endeavours to correct the inconsistent ideas of the madman by the most authentic reasoning ... yet with all his wisdom, he will be able to do nothing. ${ }^{24}$

This can be compared to the view of William Cullen, an Edinburgh physician working later in the eighteenth century. Cullen emphasised the role of the nervous system, but for him madness was also a disorder of the mind. He wrote: 'The doctrine which explains the condition of the body and of the mind necessary to life and health, is called physiology: I have added here a particular in my physiology that is not common - "and of the mind": ... I find that the conditions of the human mind

Michel Foucault', in Barbara C. Malament (ed.), After the Reformation: Essays in Honor of J.H. Hexter (Manchester, 1980).

22 R. A. Houston, Madness and Society in Eighteenth-Century Scotland (Oxford, 2000), 114.

23 Akihito Suzuki, 'Dualism and the Transformation of Psychiatric Language in the Seventeenth and Eighteenth Centuries', History of Science: An Annual Review of Literature, Research and Teaching, xxxiii (1995), 418.

24 Quoted in ibid., 425. On Boerhaave see Andrew Cunningham, 'Medicine to Calm the Mind: Boerhaave's Medical System, and Why It Was Adopted in Edinburgh', in Andrew Cunningham and Roger French (eds.), The Medical Enlightenment of the Eighteenth Century (Cambridge, 1990). 
must engage our attention more than they have done hitherto' ${ }^{25}$

In this context, there was a growing trend towards interpreting ghosts as a purely psychological phenomenon. This shift has been well documented by scholars working on England. Terry Castle argues that over the eighteenth century a psychologised view of apparitions 'gradually came to prevail', fuelled by developments within natural philosophy and theology, as well as the breakup of traditional communities in the wake of urbanisation and economic modernisation. ${ }^{26}$ Similarly, Shane McCorristine writes: 'The dialectic of the Enlightenment in eighteenth-century Western Europe radically altered interpretations of ghost-seeing by relocating the ghost from the external, objective and theologically structured world to the internal, subjective and psychologically haunted world of personal experience'.27

It should be stressed that psychological explanations for ghosts were not new to the eighteenth century. Ludwig Lavater's De Spectris suggested that ghosts were often hallucinations resulting from melancholy, fear, madness, drunkenness or weakness of the senses. George Buchanan wrote that Kenneth III (Kenneth II by modern reckoning) murdered his son's rival in the late tenth century, and was subsequently admonished by a voice from Heaven. Buchanan explained that this voice was 'either a true one, as some think, or else such an one as his disquieted mind suggested (as it commonly happens to guilty consciences)'. ${ }^{28}$ Robert Burton's Anatomy of Melancholy (1621) also argued that if people were very melancholic, 'dead mens bones, hobgoblins, ghosts, are ever in their minds', and in 1656, Hobbes wrote: 'For some men, as well sleeping as waking, but especially to guilty men ... Fear alone, helped a little with the stories of such Apparitions, hath raised in their minds terrible

25 Quoted in Suzuki, 'Dualism', 433. See also Houston, Madness and Society, 270-1.

26 Terry Castle, The Female Thermometer: Eighteenth-Century Culture and the Invention of the Uncanny (Oxford, 1995), ch. 10, quotation 170. See also Owen Davies, The Haunted: A Social History of Ghosts (New York, 2007), ch. 5.

27 Shane McCorristine, Spectres of the Self: Thinking About Ghosts and Ghost-Seeing in England, 1750-1920 (Cambridge, 2010), 31.

28 Ludwig Lavater, Of Ghostes and Spirites Walking by Nyght, trans. Robert Harrison (London, 1572, STC 15320), 113; George Buchanan, Rerum Scoticarum Historia, ed. Dana F. Sutton, electronic edn (University of Birmingham, 2009), http://www.philological.bham.ac.uk/boece, accessed 1 Aug. 2015, bk. vi, para. 35. 
Phantasmes, which have been, and are still deceiptfully received for things really true'. ${ }^{29}$ Stuart Clark has demonstrated that in the wake of the Reformation, and particularly over the seventeenth century, the status of apparitions as genuine visual phenomena became less and less secure. ${ }^{30}$

However, these explanations became significantly more common in the eighteenth century, particularly the second half of it. Castle identifies Daniel Defoe (1660?1731) as a transitional figure. Although he believed that some apparitions were real, Defoe wrote of how they could also be caused by vapours entering the brain, perhaps as a result of hypochondria, perhaps due to a guilty conscience. ${ }^{31}$ In Scotland, the minister William Cockburn linked hauntings and guilty consciences in a 1726 pamphlet, while in a 1766 trial from Aberdeen it was used as evidence against the accused that he was 'frighted with ghosts and apparitions'. ${ }^{32}$ The powers of the imagination were also emphasised. In 1749 the Scots Magazine published a piece by Thomas Melvill arguing that apparitions were often figments of the imagination, with the 'natural timorousness' of the human mind leading it to pick ghosts out in the dark. ${ }^{33}$ Henry Home, Lord Kames, similarly noted the disquieting effect of darkness:

The object, which, in the dark, is seen but obscurely, leaves the heated imagination at full liberty, to bestow upon it the most dreadful appearance. This phantom of the imagination, conceived as a reality, unhinges the mind, and throws it into a fit of distraction. The imagination, now heated to the highest degree, multiplies the dreadful appearances to the utmost bounds of its conception. The object becomes a spectre, a devil, a hobgoblin, something more terrible than ever was seen or described. ${ }^{34}$

29 Robert Burton, The Anatomy of Melancholy (Oxford, 1621, STC 4159), 260; Hobbes quoted in Davies, Haunted, 142.

30 Stuart Clark, Vanities of the Eye: Vision in Early Modern European Culture (Oxford, 2007), 204 35, esp. 211.

31 Castle, Female Thermometer, 175.

32 William Cockburn, The Being of God Proved from the Universal Voice of Conscience (Edinburgh, 1726), 8; 'The Horrors and Torment of an Evil Conscience; and the Effects of a Disturbed Imagination', Weekly Magazine, or Edinburgh Amusement, 24 Oct. 1770, 100; 'The Abstract of the Trial of Helen Watt and William Keith, Continued', Scots Magazine, Dec. 1766, 625.

33 [Thomas Melvill] 'T. M.', 'An Essay on Dreaming; Or, the State of the Mind in Sleep', Scots Magazine, Sept. 1749, 445.

34 Henry Home Kames, Essays on the Principles of Morality and Natural Religion (Edinburgh, 1751), pt. ii, 313 . 
Adam Ferguson underlined the importance of habits of thought: 'The person who habitually conceives that the church yard is haunted, or that goblins ply in the dark, trembles with fear, where another having no such conception is calm and undisturbed; and the mind, in either case, may be said to be the author of its own good, or its own harm'. ${ }^{35}$ An 1800 article in the Glasgow Miscellany similarly emphasised what it termed the association of ideas, noting that young people who have been scared by the idea of apparitions at night 'are never left in a dark room without thinking of apparitions' ${ }^{36}$

For physicians, ghost-seeing became a symptom of some kind of disorder. In physicians' notebooks examined by Houston, one man's mind was said to have been so spoiled by alcoholism that when he could not drink he started 'imagining his house was haunted with spectres or devils'. An illiterate serving woman explained of her Glaswegian mistress Janet Brown: 'at times she is of high spirits and imagines her house is haunted by spirits and threatened every person who were near her'. ${ }^{37} \mathrm{In}$ 1813, the physician John Ferriar (1761-1815) published An Essay Towards a Theory of Apparitions, which theorised about mental disorders through the vehicle of apparitions. Ferriar explained:

It is well known, that in certain diseases of the brain, such as delirium and insanity, spectral delusions take place even during the space of many days. But it has not been generally observed, that a partial affection of the brain may exist, which renders the patient liable to such imaginary impressions, either of sight or sound, without disordering his judgment or memory. From this peculiar condition of the sensorium, I conceive that the best supported stories of apparitions may be completely accounted for. ${ }^{38}$

Samuel Hibbert's Sketches of the Philosophy of Apparitions (1824) took a similar approach, arguing that 'spectral illusions ought to be regarded as nothing more than recollected images of the mind, which have been rendered as intense as actual

35 Adam Ferguson, Principles of Moral and Political Science, 2 vols. (Edinburgh, 1792), ii, 101.

36 'Essay after the Manner of Goldsmith', The Glasgow Miscellany, Or, Amusing Companion, 2 vols. (Glasgow, 1800), ii, 212.

37 Houston, Madness and Society, 308.

38 John Ferriar, An Essay Towards a Theory of Apparitions (London, 1813), 14-15. 
impressions'. ${ }^{39}$ In 1832 the Scottish physicist David Brewster expanded on this theme, addressing his work to Walter Scott, who had himself explored physiological and psychological causes of apparitions in Letters on Demonology and Witchcraft (1830). ${ }^{40}$ Brewster summarised Hibbert's 'admirable' work with the explanation that 'the pictures in the "mind's eye" are more vivid than the pictures in the body's eye'. He continued: 'I propose to go much farther, and to show that the "mind's eye" is actually the body's eye, and that the retina is the common tablet on which both classes of impressions are painted, and by means of which they receive their visual existence according to the same optical laws'. ${ }^{41}$ When the pupil expands in the dark, he explained, it becomes impossible to see nearby objects distinctly. Nearby objects or living beings that reflect the light therefore become blurry white shapes, and are easily appear supernatural, especially if 'coloured with all the vivid hues of the imagination'. ${ }^{42}$ Similarly, changing light might cause figures to vanish. Brewster also explained apparitions as arising 'from a disordered state of the digestive organs'. ${ }^{43}$ Ghost-seeing was not necessarily taken as a sign of actual insanity, but it was treated as a trick of the mind or body.

Just as discussion of psychological disorders and the power of the imagination flourished in the eighteenth and early nineteenth centuries, new discourses developed around the topic of dreaming. It was not uncommon for ghosts to appear in dreams. For many writers, this did not detract from their credibility. There were two main schools of thought regarding dreams in the eighteenth century. Some argued that they were a natural phenomena caused by physiological processes; others believed that they were supernaturally inspired ${ }^{44}$ Robert Wodrow fell into the latter category. $\mathrm{He}$ told a story of a man who was so consumed by desire for a serving maid that 'he either dreamed, or, (if I mind,) the bed he lay in was burnt three times ... the fire

39 Samuel Hibbert, Sketches of the Philosophy of Apparitions: Or, An Attempt to Trace Such Illusions to Their Physical Causes, 2nd edn (Edinburgh, 1825), 133.

40 See Michael Charlesworth, Landscape and Vision in Nineteenth-Century Britain and France (Aldershot, 2008), 40-4.

41 David Brewster, Letters on Natural Magic, Addressed to Sir Walter Scott (London, 1832), 48-9.

42 Ibid., 15-17.

43 Ibid., 47.

44 Jennifer Ford, Coleridge on Dreaming: Romanticism, Dreams and the Medical Imagination (Cambridge, 1997), 14. 
within brought fire without; which was God contending with him, or the Devil permitted, in his agency'. ${ }^{45}$ The possibility that the whole might have been only a dream made it no less notable to Wodrow, and no less an example of the workings of God (or the Devil). Andrew Baxter's 1733 Enquiry into the Nature of the Human Soul suggested that dreams were caused by spiritual beings who entered man's soul as he slept and took control of his senses, while the Relief Church founder Thomas Gillespie (1708-74) theorised that dreams were usually 'the vain rovings of the imaginations', but believed that they might also be 'the effect of the agency of good or evil spirits'. ${ }^{46}$

However, as the eighteenth century progressed the physiological explanation of dreams became more popular. ${ }^{47}$ Thomas Mevill and Dugald Stewart presented dreams as products of the imagination, and the 1797 Encyclopedia Britannica rejected Andrew Baxter's invasive spirits as implausible, declaring instead that dreams were determined by health, habits and patterns of thought. ${ }^{48}$ The physician John Brown in his Elementa Medicinae (1780) argued that dreams were caused by the nerves responding involuntarily to outside impressions, while the surgeon Robert MacNish explained dreaming through phrenology, ascribing it to one or more organs of the brain remaining awake while the others slept. ${ }^{49}$ By 1850 , a book of dream interpretations published in Edinburgh with the title The True Fortune Teller contained the following disclaimer:

The foregoing pages are published principally to show the superstitions which engrossed the mind of the population of Scotland during a past age, and which are happily disappearing before the progress of an enlightened civilisation. It is hoped, therefore, that the reader will not attach the slightest importance to the solutions of the dreams as rendered above, as dreams are generally the result of a

45 Robert Wodrow, Analecta: Or Materials for a History of Remarkable Providences Mostly Relating to Scotch Ministers and Christians, ed. Matthew Leishman, 4 vols. (1842-3), ii, 315.

46 Ford, Coleridge on Dreaming, 18; Kenneth B. E. Roxburgh, Thomas Gillespie and the Origins of the Relief Church in 18th Century Scotland (Bern, 1999), 48.

47 Ford, Coleridge on Dreaming, 14.

48 [Melvill], 'Essay on Dreaming', 442, 446; Dugald Stewart, Elements of the Philosophy of the Human Mind, 3 vols. (London, 1792-1827), i, 320-39; Ford, Coleridge on Dreaming, 22.

49 Ford, Coleridge on Dreaming, 28-9; Robert Macnish, The Philosophy of Sleep, 2nd edn (Glasgow, 1838), 41-111. 
disordered stomach, or an excited imagination. ${ }^{50}$

In this context, dreams were increasingly used as a means of explaining supernatural experiences, rather than an example thereof. Macnish argued that 'spectral illusions' were 'involuntary walking dreams' caused by inflammation of the brain. He continued: 'I allude to a large development of the organ of Wonder. Individuals with such a development are both strongly inclined to believe in the supernaturality of ghosts, and peculiarly liable to be visited by them. ${ }^{51}$ Physician and philosopher John Abercrombie also linked dreaming to spectral illusions, arguing in 1830 that 'A person, under the influence of some strong mental impression, drops asleep for a few seconds, - perhaps without being sensible of it: some scene or person connected with the impression appears in a dream, and he starts up under the conviction that it was a spectral appearance'. ${ }^{52}$

Amidst extensive discussion of the powers of the imagination, stark warnings were issued as to what would become of children whose minds were poisoned with ghost stories. The fourth edition of John Locke's Essay Concerning Human Understanding (1700) included his influential essay on the association of ideas, in which complained about nursery maids indoctrinating children:

The ideas of goblins and sprites have really no more to do with darkness than light: yet let but a foolish maid inculcate these often on the mind of a child, and raise them there together, possibly he shall never be able to separate them again so long as he lives, but darkness shall ever afterwards bring with it those frightful ideas, and they shall be so joined, that he can no more bear the one than the other. ${ }^{53}$

Writers often returned to this theme as the eighteenth century progressed. Writing in

50 Quoted in Maureen Perkins, 'The Meaning of Dream Books', in Daniel Pick and Lyndal Roper (eds.), Dreams and History: The Interpretation of Dreams from Ancient Greece to Modern Psychoanalysis (Hove, 2004), 127.

51 Macnish, Philosophy of Sleep, 246. See also George Combe, A System of Phrenology, 3rd edn (Edinburgh, 1830), 309-14; J. Mitchell and John Dickie, The Philosophy of Witchcraft (Paisley, 1839), 149.

52 John Abercrombie, Inquiries Concerning the Intellectual Powers and the Investigation of Truth, 2nd edn (Edinburgh, 1830), 369.

53 John Locke, An Essay Concerning Humane Understanding, 4th edn (London, 1700), bk. iii, ch. xxxiii, para. 10, p. 223. 
the 1790s, Elizabeth Mure of Caldwell commented that from about the mid-century there was a new cultural emphasis on liberty, and with girls 'the outmost care was taken that fear of no kind should inslave the mind; nurses were turned off who would tell the young of Witches and Ghosts'. ${ }^{4}$ Also in the 1790s, James Beattie criticised the practice of telling children ghost stories, while the poet Thomas Blacklock suggested that children should be told only of benevolent ghosts, not of 'vindictive ghosts, vindictive fiends, or avenging furies', which 'seize and pre-occupy every avenue of terror which is open in the soul'. Blacklock cautioned: 'Sooner should we hope to exorcise a ghost, or appease a fury, than to obliterate their images in a warm and susceptible imagination, where they have been habitually impressed, and where those feelings cannot be dissipated by external phaenomena'. ${ }^{55}$

This hints at another theme that featured frequently in writing on ghosts in the eighteenth century: the gender and class-based nature of ghost belief. Eighteenthcentury discussions of ghosts often framed them as a vulgar superstition propagated by folk from the lower classes, especially women, whose minds had not received the benefits of a good education. Theophilus Insulanus noted that a fellow minister had objected that a general belief in apparitions 'might be hurtful in its consequences, as it would be apt to excite and lead us to superstition, to which severals of the unlearned, especially, are already disposed, and perhaps constitutionally inclined' ${ }^{56}$ Even folk who believed in ghosts could mock the 'vulgar' for their credulity. Mrs McDonald, author of a 1797 novel called Evening Amusements, had a character explain that

I have heard of wonderful apparitions, and visions, but I don't believe one word of them. That all old towers are haunted, is a common vulgar notion; the age and wasted gloomy figures of these old buildings, and their being at a distance from where the family inhabits, throws a sadness on the fancy, and a dread follows,

54 Elizabeth Mure, 'Some Remarks on the Change of Manners in My Own Time, 1700-1790', in William Mure (ed.), Selections from the Family Papers Preserved at Caldwell, 3 vols. (Glasgow, 1854), i, 270.

55 James Beattie, Elements of Moral Science, 2 vols. (Edinburgh, 1790-3), ii, 142; Thomas Blacklock, Poems by the Late Reverend Dr. Thomas Blacklock (Edinburgh, 1793), xxiv. For a nineteenth-century example see Mitchell and Dickie, Philosophy of Witchcraft, 277, 171.

56 Theophilus Insulanus, A Treatise on the Second Sight, Dreams and Apparitions (Edinburgh, 1763), 112. 
which brings these ideal phantoms into the imagination, which is often the foundation of these foolish stories, seen and heard only by vapourish heads. That there is, and may be ghosts, I don't dispute; but never think a departed soul has so little employment as to return to earth to frighten old women and children, who never knew them nor their stories on earth. ${ }^{57}$

Associating ghost belief with 'old wives' from the lower classes was nothing new, and there was probably some truth in the idea that serving women told a disproportionate amount of ghost stories, in their capacity as nursemaids and nannies. Nevertheless, educated circles (particularly the literary world) also played a crucial role in developing and popularising conceptions of ghosts, even as they mocked common folk for believing in them. ${ }^{58}$

Belief in apparitions was also associated with certain religious groups. The Quakers and the Methodists were prime candidates, especially in England, but to a lesser extent in Scotland as well. The minister John Brown offered a sardonic rebuttal to the writing of one Mr Cressy, who argued that 'God reveals himself to the soul by a supernatural species impressed in her, which revelations are either sensible, as apparitions, words \&c. or intellectual, either immediatly, or by Angels'. Brown retorted: 'Our Quaker might have given us some such thing as a more likely ground of their quaking and trembling', adding that 'our Quakers way and worshipe hath been long ago in use among, \& much applauded by the Fanatick Papists'. ${ }^{59}$ During his tour of Scotland with Samuel Johnson, James Boswell made a remark to the Duchess of Argyll that implied a belief in second sight. In Boswell's words: 'The duchess said, "I fancy you will be a Methodist" - This was the only sentence her grace deigned to utter to me'. ${ }^{60}$ More generally, belief in apparitions continued to be linked to religious enthusiasm. A friend of Henrietta Ogilive's destroyed her papers on the Laird of Coul's ghost because she did not want Henrietta to have the power to mar her father's character and 'show [her] inthusiasm to the world' ${ }^{61}$ As we have

57 Mrs A. McDonald, Evening Amusements, Or, What Happens in Life, a Novel, 2 vols. (Edinburgh, 1797), ii, 3-4.

58 See chapter 4.

59 John Brown, Quakerisme the Path-Way to Paganisme (Edinburgh, 1678), 431. Cressy is quoted here.

60 Quoted in R. C. Finucane, Ghosts: Appearances of the Dead and Cultural Transformation (Amherst [N.Y.], 1996), 159.

61 Henrietta Hog to Elizabeth Steuart, 24 Mar. 1788: NLS, MS. 10785. 
seen, the minister John Logan noted that a ghost-seer would be considered 'a visionary enthusiast, disturbed in his imagination'. ${ }^{62}$ Scottish minister William Duff's Essay on Original Genius (1767) explained that enthusiasm 'is almost universally taken in a bad sense; and, being conceived to proceed from an overheated and distempered imagination, is supposed to imply weakness, superstition, and madness'.63

Class snobbery and psychological explanations were united in the particularly thorough rejection of ghosts given in the third edition of the Encylopcedia Britannica, produced in Edinburgh in 1797. The second edition (1778) had included an article on second sight, which reproduced a wholly sceptical assessment by James Beattie. ${ }^{64}$ The 1797 edition was actually more sympathetic on this topic, retaining Beattie's evaluation but also offering the view of Samuel Johnson, who argued that reason could not disprove second sight and that it was therefore natural to 'yield to the force of testimony'. ${ }^{65}$ However, articles on 'ghost' and 'spectre' were added to this edition, and were decidedly sceptical. The article on ghosts largely reproduced Francis Grose's 1787 summary of ghost traditions, and referred the reader to the article on spectres for a philosophical discussion of apparitions. ${ }^{66}$ This latter article addressed the subject at length. It began by defining a 'spectre' as 'an apparition, something made preternaturally visible to human sight, whether the ghosts of dead men or beings superior to man'. The belief in dead men returning, it noted, had been common for many centuries, and was known in 'rude and savage' nations. It continued:

In Christian countries, too, notwithstanding the additional light which their religion has spread, and the great improvement in the sciences to which it has

62 John Logan, Sermons by the Late Reverend John Logan, 2 vols. (Edinburgh, 1790-1), ii, 51.

63 William Duff, An Essay on Original Genius; and Its Various Modes of Exertion in Philosophy and the Fine Arts, Particularly in Poetry (London, 1767), 170.

64 'Second-Sight', Encyclopcedia Britannica; Or, a Dictionary of Arts, Sciences, \&c., 2nd edn, 10 vols. (Edinburgh, 1778-83), x, 8071-2.

65 'Second Sight', Encyclopcedia Britannica; Or, a Dictionary of Arts, Sciences, and Miscellaneous Literature, 3rd edn, 20 vols. (Edinburgh, 1797), xvii, 236.

66 'Ghost', Encyclopcedia Britannica; Or, a Dictionary of Arts, Sciences, and Miscellaneous Literature, 3rd edn, 20 vols. (Edinburgh, 1797), vii, 719-21; 'Spectre', Encyclopcedia Britannica; Or, a Dictionary of Arts, Sciences, and Miscellaneous Literature, 3rd edn, 20 vols. (Edinburgh, 1797), xvii, 677-84. 
been subservient, the belief of ghosts and apparitions is very general, especially among the lower ranks. They believe that evil spirits sometimes make their appearance in order to terrify wicked men, especially those who have committed murder.- They suppose that the spirits of dead men assume a corporeal appearance, hover about churchyards and the houses of the deceased, or haunt the places where murders have been committed. ${ }^{67}$

The article then attacked belief in spectres. Death was too profound a change to be undone. Ghosts could serve a useful function by demonstrating the reality of the afterlife or enforcing moral codes, but Scripture already told man everything he needed to know on that front. The article complained that ghosts did not follow the rules of common sense; they never reported crimes to magistrates or judges, but rather divulged their information 'to some illiterate clown, who happens to live near the place where the crime was perpetrated; to some person who has no connection with the affair at all, and who in general is the most improper in the world for making the discovery'. In fact, ghosts never appeared before men 'of education and learning', but only to the 'ignorant' and 'credulous' ${ }^{68}$ The article went on to proffer explanations for ghost sightings, from 'the prejudices of the nursery' and the powers of imagination, to indistinct vision, dreams, opium, drunkenness, diseases such as 'the night-mare, the hypochondria, hysteric passion and madness', exaggerated rumours and the 'artifices of the waggish or self-interested' ${ }^{69}$

Over the hundred years from the early eighteenth to the early nineteenth century, scepticism towards ghosts did not necessarily become more common; it merely changed. Ghost belief was mocked or pitied, associated with the ignorant and the insane. John Logan argued that a ghost-seer would be met with such universal scepticism that it is ten to one but he falls in with the opinion of the world, and believes the apparition to have been the phantom of his own fancy' ${ }^{70}$ However, the originality and potential impact of this scepticism should not be over-emphasised. Ghost belief had not had a place in mainstream intellectual culture since the Reformation. At the beginning of the eighteenth century the primary way to dismiss

67 'Spectre', 677.

68 Ibid., 678-9, 680.

69 Ibid., $682-3$.

70 Logan, Sermons, 51. 
ghosts was to redefine them as demons; by the end of the century the most common sceptical approach was to present ghosts as products of the mind. Being distanced from their association with demons and witches was probably a positive change for ghosts; there was more freedom for folk to talk about them without fear of being suspected of dealings with the Devil. Furthermore, ghosts were used by philosophers and physicians as a device through which to develop and discuss new theories regarding mental disorders, which offered them a place within the intellectual culture in the eighteenth century (particularly the latter half of it). As one author put it:

Though these waking visions are the mere illusive creations of a diseased or overexcited imagination, they are not on that account the less worthy of the attention of the philosopher, as well as the physician: and instead of being regarded with the terror of the vulgar, or the disdain of the sceptic, they claim the calm and unprejudiced researches of philosophy, for the purpose of tracing their various phenomena to natural causes, and accurately ascertaining their relation to the state of the brain and the external senses. ${ }^{71}$

Ghost belief was still associated with folk culture (as it had been for centuries), but discussion about ghosts appeared much more frequently in the eighteenth century than it had in the seventeenth - in contrast to R. C. Finucane's assertion that apparitions 'no longer played an important part in the serious debates of the articulate' ${ }^{72}$ While there were newly popular ways to explain away ghosts, this does not mean that they were exorcised from society.

\section{Ghosts and the Authorities}

On the rare occasions when ghosts appeared before kirk or secular authorities in the eighteenth century, they were usually received sceptically. In June 1711, Bishop Alexander Rose wrote of a case of sweet music and voices heard emanating from an abbey by soldiers. He explained that this was so much talked about that the local advocate ordered a report from a baillie, which was then to be sent to court. However, the baillie clearly had a low opinion of the whole affair, and was careful to

71 Mitchell and Dickie, Philosophy of Witchcraft, 146.

72 Finucane, Ghosts, 165. 
question the wrong people and ask the wrong questions, ensuring that there was nothing to report on.$^{73}$ In this case, both Rose and the advocate were ready to take the story seriously even if the baillie was not, but usually the records reveal a more uniform scepticism on the part of the educated authorities. In 1730, the Edinburgh burgh court entered a servant into the town's black book for spreading a rumour that her former employer's house was haunted. ${ }^{74}$

The kirk session of Chapel of Garioch, Aberdeenshire, recorded an interesting case from $1737 .{ }^{75}$ A farmer died, leaving behind a wife and seven sons. The following spring his widow died as well. A few months later their eldest son, Geordie Watt, visited his local minister. He reported that about three or four weeks after his mother's death, a ghost had started appearing to him and his brothers. It had declared itself to be 'the very spirit of their glorified mother', sent from Heaven to 'reveal several things to them for their temporal and eternal good'. The ghost spoke in a 'shrill and heavenly voice', wore a white veil, and was 'covered with white clean linnen head and arms down to the middle of the body before, and somewhat farther behind'. It gave them good advice, and told them 'the very secrets of their hearts', but its chief purpose was to instruct them 'that it was the will of the great God that Geordie Watt should marry Tibbie Mortimer, because that Tibbie was now in a gracious state, and had been predestinated to glory from all eternity'. Tibbie (or Isabel) Mortimer was the only female servant in the family. When Geordie protested, the ghost gathered him and his brothers together and insisted that 'unless Geordie Watt should marry Tibbie Mortimer, he and all his brothers, and all things belonging to them, should certainly be consumed with fire from heaven!' Geordie then consulted the minister, who visited the farm. He sat up with the brothers and waited. Sure enough, after some hours, a voice was heard outside a little window in Geordie Watt's bedroom. It pronounced 'with a wild and vehement tone' that it had come to speak to them all in the name of the Trinity. The brothers were afraid, but the minister leapt up and ran outside. He saw the shape of a woman, draped from head to

73 Alexander Rose to Archibald Campbell, 28 June 1711: NRS, CH12/12/1823.

74 R. A. Houston, Social Change in the Age of Enlightenment: Edinburgh, 1660-1760 (Oxford, 1994), 191.

75 Presented and discussed in William Alexander, Notes and Sketches Illustrative of Northern Rural Life in the Eighteenth Century (Edinburgh, 1877), 203-7. 
toe in white linen. He charged over, and as the session coyly recorded, he 'made such a trial of the apparition as he thought agreeable to the principles of the Christian revelation and true philosophy'; that is, he hit her with a stick, and thus discovered that she was no incorporeal spirit. Stripping away her veil, he revealed Tibbie Mortimer herself.

The minister lectured her on the 'blasphemy, devilish tricks, and mischievous pranks', but Tibbie responded insolently, and only the pleas of the family kept her from being handed over to the civil magistrate. She was dismissed from her post. The kirk session branded her a 'vile, base, and impudent woman', and accused her of having behaved 'in a course of horrid blasphemy' and having 'prescribed charms and suspicious things'. It referred her to the presbytery for judgement. Some ten months later the presbytery convicted her of "the sin and scandal of fornication with George Watt in Bridgend, as also of acting the part of a ghost and blaspheming the holy name of God'. She was ordered to appear in sackcloth before the congregation. Tibbie was initially defiant, but eventually accepted her punishment, which lasted from December 1738 until March 1740. Interestingly, Geordie was also involved. It is probable that there was a pregnancy in the case: the allusion that Tibbie was in a 'gracious state' implies as much. Geordie was suspected of being 'in less or more conscious of, or having a hand in the abominable part that Isa. Mortimer acted', and was also ordered to appear in sackcloth. He objected that 'he would never satisfy in sackcloth for that which he knew nothing about', but did offer to make a penitential payment instead, which the session accepted. When Geordie and Tibbie's affair began, and whether they had concocted the ghost plan together, cannot be known.

Another interesting story concerns a minister from Muckhart called David Wilson. Wilson was involved with (at least) two Presbyterian denominations: the AntiBurghers and the Relief Synod. In 1733 the Secession had given rise to the Associate Presbytery, an alternative to the Church of Scotland. The Associate Presbytery had itself divided in 1747 over the question of the Burgher Oath. This was an oath to be sworn by a town burgess upon taking office, approving of the religion 'presently professed in this kingdom'. The Burghers and the Anti-Burghers had formed separate 
synods. The Relief Church was a Presbyterian denomination founded in 1761 by Thomas Gillespie after his deposition for opposing patronage. It had grown rapidly and had established its own synod in $1773 .{ }^{76}$ Wilson joined the Relief Synod in May 1793; he began work in Pittenweem the next year. ${ }^{77}$ Before joining the Relief Synod, he was apparently refused a licence by the Anti-Burghers for claiming that a ghost had appeared to him. This emerged in a pamphlet by an Aberdeenshire man called David Gellatly, who was ordained as the first Relief minister in Haddington in 1792, and deposed two years later on a charge of immorality. Wilson had formed one of the committee appointed to inspect the process against Gellatly. The pamphlet attacked Wilson, alongside other committee members. Gellatly wrote:

I must in justice to myself and to mankind observe, had it been true, as you maintain it is, that when you taught a private school near Alloa, a ghost appeared to you, and told you of some cruelty which others committed; this stranger would have deterred you from any act of injustice. Upon account of this story, I opposed your admission among the Relief; for I am firmly persuaded, like many others, that as Brissot's ghost was only two or three sheets of printed paper, so the ghost which you saw was a fair folio in sheets, which you polluted during night. ${ }^{78}$ The Antiburghers refused you licence upon that account; at least they did not believe that you saw any ghost. The story which you told and fathered upon the ghost, concerning some respectable people in your then neighbourhood, was highly criminal, and for which they might have caused you severely suffer. Did the real ghost that you saw and felt with pleasure, father any thing upon you ${ }^{79}$

Again, this story demonstrates clear scepticism, both on the part of Gellatly and the Anti-Burghers (assuming Gellatly's version of events is accurate). Wilson's ghost seems to have followed traditional patterns in revealing a crime or injustice, but it is Wilson himself who is accused of 'highly criminal' behaviour. Although Wilson was accepted into the Relief Synod, the Anti-Burghers' rejection indicates that ministers were not supposed to be spreading ghost stories.

76 See, for example, Colin Kidd, 'Conditional Britons: The Scots Covenanting Tradition and the Eighteenth-Century British State', English Historical Review, cxvii (2002), 1158-9; Steve Bruce, Scottish Gods: Religion in Modern Scotland, 1900-2012 (Oxford, 2014), 10; Roxburgh, Thomas Gillespie.

77 William Mackelvie, Annals and Statistics of the United Presbyterian Church (Edinburgh, 1873), 455.

78 This referred to a well-known pamphlet, Brissot's Ghost! Or, Intelligence from the Other World (Edinburgh, 1794).

79 David Gellatly, Relief Procedure Justly Exhibited (Edinburgh, 1794), 80. 
Another prominent case presents a similar clash between a ghost and the authorities. In June 1754, Duncan Terig (alias Clerk) and Alexander Bain Macdonald of Aberdeenshire were tried for the murder of Arthur Davies, a sergeant in General Guise's Foot Regiment. ${ }^{80}$ In 1749, Davies and others from his regiment were quartered in Braemar in Aberdeenshire. Davies went for a walk and was allegedly pursued, shot and robbed by Clerk and Macdonald. They were apprehended in 1753 and brought to trial the following year. An eye-witness was found, who claimed to have been concealed in a hollow in the hill and to have seen Clerk and a companion shoot a man in blue and then handle the body. Testimony of several witnesses described seeing Macdonald, Clerk and the latter's wife in possession of various valuables once owned by Sergeant Davies. Macdonald and Clerk both claimed that they had been out shooting deer, but their accounts were inconsistent.

Thus far, the weight of evidence seems to have been against Clerk and Macdonald. However, there was another source of evidence against them which may, if anything, have worked in their favour. A local man, Alexander Macpherson, attested that while he was in bed one night a blue-clad apparition had appeared to him. This apparition explained that he was Sergeant Davies, and gave the location of his murder, asking Macpherson to go and bury his bones. Macpherson asked him who his murderer was, but the apparition replied 'that if [Macpherson] had not asked him, he might have told him, but as he had asked him, he said he either could not or would not' ${ }^{81}$ Macpherson did not go to bury the bones, and the vision re-appeared, now naked, to appeal again. Macpherson repeated his question about the murderer, and this time the apparition replied that Clerk and Macdonald were the culprits. Macpherson then enlisted a friend's help; they found the bones in the spot described and buried them. In answer to a question from the defence advocate, Macpherson asserted that the ghost had spoken to him in Gaelic, not a language Davies had known. The advocate (probably not without a degree of class prejudice) mocked the idea that an English

80 Reproduced in Walter Scott (ed.), Trial of Duncan Terig Alias Clerk, and Alexander Bane Macdonald, for the Murder of Arthur Davis, Sergeant in General Guise's Regiment of Foot (Edinburgh, 1831).

81 Ibid., 29. 
ghost would speak Gaelic, and it is clear that the court was reluctant to accept the evidence. Clerk and Macdonald were acquitted.

In 1779, the Scots Magazine published a story from Cheshire of a man who claimed to have been visited by a dead man's ghost in his sleep. ${ }^{82}$ The ghost had revealed the location of his body and the name of his murderer. A search was conducted, and the body was found in the location the ghost had given. However, during the trial of the supposed murderer, the judge called the ghost to court. When the ghost failed to materialise, the judge had the dreamer arrested and convicted of the murder. A search of the dreamer's house discovered the dead man's belongings, vindicating the court's decision. This trial may not really have taken place, but even if it did not, it further demonstrates the idea that ghosts had no place in a courtroom. There was an element of mockery in the judge's calling the ghost to court, just as there was in Macdonald and Clerk's advocate's scorn at the idea that an English ghost would speak Gaelic. Focus on these practicalities drove the mind away from traditional aspects of ghost stories - that ghosts could only appear at certain times and places and to certain people, or that ghosts had access to new spheres of knowledge - and forced ghosts to inhabit the everyday world, where their supernatural elements became fantastical. These cases also demonstrate the story-book trope of a wise figure - the minister, the defence advocate, the judge - outwitting a foolish trickster, who in these cases was often an uneducated member of the lower classes, perhaps not even able to speak English.

However, there were also cases where supernatural intervention was treated more sympathetically. In the spring of 1830 a pedlar was murdered in in Assynt, Sutherland. ${ }^{83}$ His body was recovered from a lake. Suspicion fell on a man called Hugh Macleod, as he had changed a ten pound note at the post office despite living in relative poverty. No further evidence was found to connect him with the crime, however, and he was on the verge of being released when a tailor called Kenneth

82 'Discovery of a Murderer', Scots Magazine, Sept. 1779, 484.

83 Brutal Assault and Murder! ([Scotland?], 1830); 'Singular Ghost Story', Aberdeen Magazine, Feb. 1832, 94; Robert Chambers, The Book of Days, A Miscellany of Popular Antiquities (London, 1863-4), i, 394-5. 
Fraser came forwards, avowing that he had dreamt about the murder. He had seen the cottage Macleod was living in, and a voice had explained (in Gaelic) that the pedlar's pack was hidden in a cairn of stones near the house. The articles were found as described, and Macleod was later discovered to be in possession of a pair of stockings that had belonged to the pedlar. He was tried at the Circuit Court in Inverness, and Fraser gave evidence, explaining his dream. Macleod was found guilty and executed. Before his death he confessed the murder, and avowed: 'Kenneth Fraser, the dreamer, knew nothing of my transactions, or any thing that I have done. I now free him from the charge that has been brought against him; and I hope no person will say that he had any concern in the murder. ${ }^{, 84}$ There had evidently been some doubts about Fraser's story, but his evidence nevertheless seems to have contributed to Macleod's conviction.

A final case was reported in 1848 by the English writer Catherine Crowe, who claimed to have heard it from Maurice Lothian, the pursuer's advocate. In 1835 a landlord called Mr Webster brought a case against his tenant, Captain Molesworth. ${ }^{85}$ Molesworth had rented a house of his a few miles from Edinburgh. The family had lived there for about two months when they began to be troubled by strange noises. They heard footsteps, scratching, rustling; the walls trembled and sometimes the beds were lifted up. Their poltergeist would even answer questions through a system of knocks. Captain Molesworth's daughter Matilda had recently died, and his other daughter Jane was sickly and spent most of her time in bed. Webster accused Jane of making the noises, while many in the neighbourhood believed them to be caused by the ghost of Matilda, warning that her sister was soon to die as well. Jane was tied up, but the noises continued. Molesworth lifted floorboards and made holes in the wall in an attempt to discover the source of the disturbances, but to no avail. Finally he decided to leave the house. Webster brought the suit against him for damage done to the property, as well as for preventing other tenants from taking it by saying it was haunted. Jane died soon after the removal, and the subsequent tenants had no problems. The case dragged out for two years, but apparently came to nothing. The

84 'Singular Ghost Story', 94.

85 Catherine Crowe, The Night Side of Nature, or Ghosts and Ghost Seers, 2 vols. (London, 1848), ii, 292-5. 
fact that the case did not reach any swift resolution again suggests that although some (such as Webster) doubted Molesworth's story, the matter was not clear cut.

Overall, all of these cases demonstrate scepticism, but they also indicate that ghosts were taken seriously to an extent. They were considered credible enough to end up in courtrooms or to be employed for personal ends. The punishments for discussing dealings with ghosts did not amount to execution, the fate suffered by many of those accused of witchcraft, as well as by Thomas Aikenhead for his blasphemy conviction. However, impersonating a ghost could still result in a charge of blasphemy and punishment by the kirk session. Eighteenth-century authorities were keen to stress their sceptical outlook, and underline the ridiculous aspects of ghost traditions. However, this in itself suggests that ghosts did have a degree of credibility and power.

\section{Popular Print Culture: Debate}

Scotland's periodical culture took off in the latter half of the eighteenth century, opening up a new venue for discussion and debate on ghosts. Periodicals were cheap publications, usually produced on a weekly or monthly basis, that discussed developments within the worlds of philosophy, theology, politics and the arts. One title is particularly useful when it comes to debates on ghosts: the Edinburgh Weekly Magazine, launched by Walter Ruddiman in July $1768 .{ }^{86}$ It had some success, reaching a circulation of around 3,000 in the late $1770 \mathrm{~s} .{ }^{87}$ Each issue began with readers' letters and essays, before moving on to poetry, reviews, and finally news. In the 1770s, the magazine printed a series of letters and essays discussing the reality (or otherwise) of ghosts. The debate was begun by an article by Philaretes, published in April 1771. (Unfortunately, the use of pseudonyms makes it impossible to identify

86 The periodical went through various titles, in part because it was restructured in 1779 to avoid stamp duty. From 1768-79 it was the Weekly Magazine, or Edinburgh Amusement; from 1779-82 it was the Edinburgh Magazine, or, Literary Amusement; and from 1782-4 it continued as the Edinburgh Weekly Magazine, although Ruddiman had died in 1781.

87 Bob Harris cited in Rhona Brown, Robert Fergusson and the Scottish Periodical Press (Aldershot, 2012), 6. 
the contributors, but it seems safe to assume that most were educated men.) Philaretes scorned the 'old woman in our breasts' which made so many people superstitious. His own grandmother knew Satan's Invisible World Discovered by heart, and as a child he too was subject to the 'folly' of belief in apparitions. He was once greatly terrified when he mistook some dried fish for a ghost; another time he took a goat to be a spectre. This 'preposterous education' had brought him only misery. As an adult he rejected completely the idea that the dead could leave Heaven or Hell. He did believe that spirits existed and served God - he allowed, for example, that a man might have a guardian angel - but he did not believe that these spirits could appear to humans. 'I am firmly persuaded', he declared, 'that no man ever did see an apparition, unless it was the product of his own fertile imagination' ${ }^{88}$

Philaretes's article was promptly questioned, in May 1771, by Will Wiseman, who urged the case of the Witch of Endor. ${ }^{89}$ In December 1771, a further retort was published by Palemon, arguing that the reality of apparitions had been proved by history and tradition. He gave biblical examples of visible spirits, and cited the 'famous' apparition of Provost Crichton, which 'may be depended on as an undoubted matter of fact'.$^{90}$ In response Philaretes insisted that Palemon was thinking of angels, which did exist. He clarified that when he rejected apparitions he meant 'those non-entities of ghosts, fairies, hobgoblins and spectres, so much dreaded and implicitly believed in by the credulous vulgar'. ${ }^{91}$ The seventeenth-century hierarchy of supernatural beliefs continued to be employed, and the debate over where Christian supernatural forces ended and superstition began remained focused on more or less the same point on the scale.

A few months later, in February 1772, a fresh retort was published, using an unconventional means to demonstrate the reality of apparitions. The author, M., told

88 Philaretes to the Weekly Magazine, or Edinburgh Amusement, 11 Apr. 1771, 33-9 (quotations 33, $35,38)$.

89 Will Wiseman to the Weekly Magazine, or Edinburgh Amusement, 9 May 1771, 165-6.

90 Palemon to the Weekly Magazine, or Edinburgh Amusement, 5 Dec. 1771, 296-7. On Crichton's ghost see p. 205.

91 Philaretes to the Weekly Magazine, or Edinburgh Amusement, 19 Dec. 1771, 355-7 (quotation 356). 
the story of a young man who mocked the existence of ghosts. He accepted a challenge from friends to descend into a crypt at night and spend some time there alone. When he did so, he was seemingly attacked by some invisible assailant, and passed out in fear. He was recovered later by his friends, who found that he had merely slipped and pinioned his own tie into the floor. However, he thereafter became a believer in spirits, reasoning that the intensity of his terror was proof enough of supernatural influence. M. suggested that even sceptics might be swayed by this 'supernatural intelligence within' ${ }^{92}$ Philaretes responded scornfully:

Mr M.'s lucubrations may do very well for a circle of women smoaking their pipes round the winter fire, but every man of inch-deep science will pity his forwardness and presumption to show himself in print, where, in point of sentiment, reasoning, judgement, and logical argumentation, he has shown that he is but a mere puking infant, not yet weaned from his mother's breast. ${ }^{93}$

In spite of these sardonic replies, several writers continued to defend ghosts. In April 1772, C.G. joined the argument. He agreed that no souls would leave Heaven, but argued determinedly for the possibility that the wicked might return. He highlighted the notoriety of the ghosts of the Laird of Coul and Provost Crichton. 'Whatever Philaretes or any other may think', he proclaimed, 'these are stubborn facts which cannot be denied'. ${ }^{94}$ The next month brought a retort from a new contributor, Fabricius. He declared that stories of ghosts could not prove anything, and dismissed the Laird of Coul chap-book as 'trifiling' and 'ridiculous', penned by 'some shallow scribbler'. ${ }^{95}$ As for Provost Crichton, his ghost was no more than a large bush. Fabricius explained that he believed in demonic spirits, but that it was ridiculous to imagine that the dead could return. Over the following years the debate acquired a host of additional participants. C.G. retorted with more stories; Palemon pointed out that Joseph Addison had believed in ghosts; Toby Rattle called the non-believers 'perfect infidels', perhaps with undertones of sarcasm; Neanias compared believers to old women, and so on. ${ }^{96}$ For the most part the same arguments were simply

92 M. to the Weekly Magazine, or Edinburgh Amusement, 6 Feb. 1772, 165-7 (quotation 165).

93 Philaretes to the Weekly Magazine, or Edinburgh Amusement, 27 Feb. 1772, 261-2 (quotation 262).

94 C. G. to the Weekly Magazine, or Edinburgh Amusement, 16 Apr. 1772, 74-5.

95 Fabricius to the Weekly Magazine, or Edinburgh Amusement, 7 May 1772, 167-8.

96 C. G. to the Weekly Magazine, or Edinburgh Amusement, 23 July 1772, 97-9; Palemon to the 
recycled. One more original response, at least in form, was Sylvander's 1772 'Directions on Making a Modern Wit':

In superficial trappings deck your mind, But let no deep reflection entrance find:

With all the scorn of indignation curse The fab'lous stories of the doating nurse, Of ghosts, hobgoblins, apparitions, seen By ruin'd walls, or fairies on the green; Of witchcraft spells, or voices from the grave; The childish bugbears of a winter's eve. Then boldly doubt what cheating priests do tell Of sep'rate souls, future heav'n or hell; The paths of common sense and nature quit, You cannot fail to be a man of WIT. ${ }^{97}$

By the end of 1774 the argument had died down, although echoes of it continued to recur in following years, or in other periodicals. At the end of the decade the Edinburgh Eighth-Day Magazine published a lengthy piece by J. $\mathrm{McC}$ in favour of ghosts, taken from a speech delivered in the Pantheon. He noted that the ancient fathers of the church were 'as much persuaded of the reality of witches and apparitions, as of their own existence', and used biblical examples to demonstrate that dead souls could return: 'we read of Moses and Elias appearing to the disciples, at our Saviour's transfiguration; and, at his resurrection, we are told, that many bodies of saints, which slept in their graves, arose, went into Jerusalem, and appeared unto many'. McC argued that it was a contemporary fashion to reject apparitions, but that the trend owed more to 'scepticism and irreligion' than its being an 'enlightened and pious age'. He noted that ghosts were allowed to appear only for 'some important end and design', and for every true story there were a hundred fabrications. Nonetheless, ghosts performed a valuable function by proving the reality of a future state. ${ }^{98}$ Clearly, no final consensus had been (or could be) reached, and familiar

Weekly Magazine, or Edinburgh Amusement, 9 July 1772, 45-6; Toby Rattle to the Weekly Magazine, or Edinburgh Amusement, 28 May 1772, 269; Neanias to the Weekly Magazine, or Edinburgh Amusement, 23 July 1772, 103-5.

97 Sylvander, 'Directions for Making a Modern Wit', Weekly Magazine, or Edinburgh Amusement, 23 July 1772, 114.

98 J. McC, 'Speech Delivered in the Pantheon', Edinburgh Eighth-Day Magazine, 13 Nov. 1779, 299-301. 
arguments might be recycled indefinitely. Although scepticism towards ghosts was common, this debate demonstrates that it was not a universal outlook, even among the educated.

\section{Popular Print Culture: Satire}

Sceptical views on ghosts were also showcased through the medium of satire. In 1792 a work called An Account of Some Imaginary Apparitions: The Effects of Fear or Fraud was printed in Dunbar. It presented a series of ghost stories, in the fashion of Sinclair. However, supernatural intervention was always ultimately disproved. When a tapping was heard at a hospital, the nurses (dryly referred to as 'sagacious ladies') refused to work any more. ${ }^{99}$ The poltergeist finally proved to be a cat. Other ghosts turned out to be a tree-stump, a burglar and an unprincipled friar. The work mocked collections such as Sinclair's, and presented rational explanations for ghostseeing: a guilty conscience, the power of established traditions. ${ }^{100}$ Periodicals often parodied ghost stories in a similar fashion. A man spent a night in a haunted house, but the 'ghost' backed off sharply after he threatened it with a pistol; another thought he was woken by a ghost and followed it, only to find he was dreaming and sleepwalking. ${ }^{101}$

In April 1796, 'Felix Phantom' first printed the Ghost, which purportedly hailed from Fairyland (we see here the folkloric tradition that fairies lived in the land of the dead). It ran for forty-six issues over the course of that year. It chiefly contained literary criticism and satirical articles on a variety of topics, but the gimmick of the ghostly editor provoked some discussion of apparitions. In the first issue, Felix Phantom introduced himself. 'I am a departed Spirit', he began, and went on to explain that ghosts resided in 'fairy regions', and could assume any number of corporeal shapes. All dead people went there, and free from the shackles of

99 An Account of Some Imaginary Apparitions, The Effects of Fear or Fraud (Dunbar, [1792?]), 12. 100 Ibid., 9.

101 The Edinburgh Medley of Entertainment, 2 vols. (Edinburgh, 1800), ii, 21-4; 'Entertaining Story of a Sleep-Walker', Edinburgh Magazine, June 1761, 294-7. 
corporeality, all were 'enlightened and good friends'. ${ }^{102}$ Indeed, Hume himself was there, and was profoundly sorry for his arguments against the supernatural. (A subsequent issue contained a letter from the ghost of Voltaire, apologising for having lured men into 'delusion' with his 'false doctrines'.) ${ }^{103}$ Felix Phantom went on to explain that ghosts had long confused men and perpetuated superstition by causing miracles and prodigies, as well as inventing witchcraft. He was writing now to clear matters up and instruct mankind - not to provide amusement for 'old women of either sex'. ${ }^{104}$

Later in the same year the periodical gave an account of a dinner party, in which an array of characters represented a range of thinking on ghosts. An old spinster, Miss Penelope Cobweb, believed wholeheartedly in ghosts, but was laughed down by the rest of the party. A gentleman suggested that, as Purgatory was a Catholic superstition, ghosts expiated their sins on earth instead. A sceptic argued that ghosts were mere figments of the imagination. A clergyman insisted that ghosts were created by the Devil. A metaphysician cited the work of Emanuel Swedenborg, and suggested that apparitions appeared only in dreams, but were nonetheless real; only in that state (or in ecstasy, or madness, or when 'divested of carnal feelings') could spirits be perceived. Finally, a chieftain from the Western Isles noted his belief in second sight, and found that all of the ladies were instantly on his side. ${ }^{105}$ Satire tended to reflect on fashionable topics, and the account of the dinner party suggests that the common templates for ghost believers and sceptics were well-known. They were not treated kindly, however. Folkloric beliefs, such as second sight, or the dead passing to the land of the fairies, were toyed with; ghost belief was the preserve of old ladies. Miracles, prodigies and witchcraft were scorned. Even the process of debating ghosts, as shown in the dinner party, was ridiculed. The Ghost was frequently scathing, in its literary reviews as much as in its comments on ghost belief, and was not without enemies. The Trifler used a piece apparently by a fellow spectre to reveal 'the vain and absurd pretensions of the most despicable and

102 Felix Phantom in the Ghost, 25 Apr. 1796, 1-2.

103 Ghost of Voltaire to the Ghost, 30 July 1796, 5-8 (quotations 5).

104 Phantom in the Ghost, 25 Apr. 1796, 4.

105 Felix Phantom in the Ghost, 18 May 1796, 29-32 (quotation 31). 
insignificant of wretches', adding 'The Ghost was the work of some fools who had the happy talent of writing nonsense with equal facility and elegance'. ${ }^{106}$ Regardless of its reception, however, the Ghost demonstrated a brand of brutally assured, mocking scepticism that was characteristic of the later eighteenth century.

Nevertheless, these magazines kept ghost beliefs in circulation. Setting aside the publication of romantic and gothic stories and poems about ghosts, which shall be discussed in the next chapter, periodicals published accounts of ghosts as well as attacking them. The Aberdeen Magazine noted that 'a belief in spectres and apparitions has prevailed in all ages of the world, and many absurd fables have been propagated respecting those beings, which were probably invented to serve particular purposes, or had their origin in ignorance and superstition'. Nonetheless, it proceeded to offer a ghost story, explaining: 'Whether the following relation be of this kind or not, we shall not pretend to determine, but we are of the opinion that it merits some attention, on account of the noise which it made at the Court of France about the end of the last century'. ${ }^{107}$

Furthermore, satirical representations of ghosts contributed to the development of ghost stereotypes. Satirical works commonly exaggerated the more fantastical elements of ghosts. This can be seen in the work of Tobias Smollett (1721-71), whose picaresque novels were popular in the mid-eighteenth century. Smollett presented more than a dozen cases of people mistakenly believing that they had seen a ghost, often because of deliberate hoaxes. These hoaxes were elaborate affairs. In one case, 'Doctor Fillet having borrowed a couple of sheets from the landlady, dressed the misanthrope and Tom Clarke in ghostly apparel, which was reinforced by a few drops of liquid phosphorus, from Ferret's vial, rubbed on the fore-heads of the two adventurers'. The phosphorus 'exhibited a pale and lambent flame, extremely dismal and ghastly to the view'. Another man had a 'ghastly wound' painted on his

106 Moropolemius to the Trifler, 4 July 1796, as given in the 1797 enlarged edn, 186-92; Richard Maw-Worm in the Trifler, 4 July 1796, as given in the 1797 enlarged edn, 192-3. The first edition included the same article but gave a different author and date. It did not include the editor's note. Feriatus to the Trifler, 21 May 1796, 199-206.

107 'Account of an Apparition in France', Aberdeen Magazine, 9 Apr. 1789, 194-5. 
forehead in order to imitate a ghost. ${ }^{108}$ The most extravagant case of all appeared in Peregrine Pickle:

To the hide of a large ox, Pipes fitted a leathern vizor of a most terrible appearance, stretched on the jaws of a shark, which he had brought from sea, and accommodated with a couple of broad glasses instead of eyes. On the inside of these he placed two rushlights, and, with a composition of sulphur and saltpetre, made a pretty large fusee, which he fixed between two rows of the teeth. This equipage being finished, he, one dark night chosen for the purpose, put it on, and, following the commodore into a long passage, in which he was preceded by Perry with a light in his hand, kindled his firework with a match, and began to bellow like a bull. ${ }^{109}$

The end result resembled 'a hideous phantom vomiting blue flame'. ${ }^{110}$ These melodramatic images assisted in the development of a romantic conception of the ghost that was not necessarily new to the eighteenth century, but did become progressively more popular.

A 1794 poem by Alexander Watson also took a satirical approach. After having attacked belief in witches, brownies, evil spirits, apparitions in the air, and fairies, Watson turned his eye to ghosts. He presented them as dramatic figures, who

Shew blood and wounds, as old wives prattle,

Or heavy loads of ir'n chains rattle;

The murder, by dumb signs, divulge,

By whom, and how, and where, promulge;

Enjoin revenge, or threats bestow.

Nor, till reveng'd can rest below! ${ }^{111}$

They donned winding sheets and lurked in dark rooms, church-yards, and lonely corners. They were afraid of daylight and cowered away at the crow of a cock. Watson mocked those Christians who were afraid of such creatures:

Then as for you good Christian folk,

108 Tobias Smollett, The Adventures of Sir Launcelot Greaves, 2 vols. (London, 1762), i, 141, 258.

109 Tobias Smollett, The Adventures of Peregrine Pickle, 3 vols. (Dublin, 1751), i, 100.

110 Ibid.

111 Alexander Watson, The Anti-Jacobin, a Hudibrastic Poem in Twenty-One Cantos (Edinburgh, 1794), 6. 
Have you less courage than a cock $?^{112}$

In fact, Scottish ghosts rarely abided by such strict criteria, and never appeared with iron chains. Similar exaggeration can be seen in The Spectre Bridegroom, a farce by William Thomas Moncrieff. It was based on Washington Irving's short story of the same name, and was first performed in London in 1821. It appeared on the Scottish stage in the 1820s. ${ }^{113}$ In Irving's story, a marriage is arranged without the parties having met, and on the way to meet the family the groom is killed. His friend goes to explain the situation, but falls in love with the proposed bride at a glance, and so conceals the truth and poses as the groom. When the news of his friend's death arrives he is thought to be a ghost, a part he continues to play until he has stolen the bride away and married her. In Moncrieff's version there is similarly no actual ghost, but the play is bursting with references to ghost traditions. Mr Nicodemus, a scholar of vampires, goes to inform a girl called Georgiana of the death of her fiancé, his cousin. ${ }^{114}$ Upon arrival he is mistaken for the fiancé, and sent to dine by Georgiana's officious father Aldwink without managing to get a word in edgeways. When a servant then arrives who has seen the cousin's body, a typically farcical exchange results:

Dick: Come - what! - ha' they brought his body here?

Aldwink: No, he brought his body here himself.

Dick: What! - in a hearse?

Aldwink: No - on a horse; and you must go and wait on him.

Dick: What - sit up all night wi' him?

Aldwink: No; only till he's finished his supper.

Dick is left to wonder, not unreasonably, "what be the good of turtle soup when a man be dead'. ${ }^{115}$ Later the whole party, excepting Georgiana's level-headed cousin Lavinia, become convinced that their visitor is a ghost. He arrives at midnight, and

112 Ibid., 8 .

113 Playbills of the Theatre Royal Edinburgh (NLS), http://digital.nls.uk/playbills, accessed 1 Aug. 2015.

114 The name implies that he will practise a deception: the Necodemites, as described by Calvin in 1544, were those who hid their true religious beliefs. Jean Calvin, 'L'Excuse à Messieurs les Nicodémites', Traité des Reliques, Suivi de l'Excuse à Messieurs les Nicodémites (Paris, 1921).

115 William Thomas Moncrieff, The Spectre Bridegroom: Or a Ghost in Spite of Himself (London, 1821), act i, scene ii, 12-13. 
retires at cock-crow; he does not eat, does not speak until forced, and groans about the dreadful secret he has to reveal. Aldwink desires to exorcise him by stopping the key holes and banishing him to the Red Sea, to which Dick responds glumly: 'It would be o' no use, 'squire; he'd come down the chimney, dress'd all in white'. ${ }^{116} \mathrm{~A}$ suitor of Georgiana's claims to have dispatched him: 'Firing was of no use; one might as well have shot at the air, for all the wounds it created; so I had at him with the Latin, Friar Bacon, Doctor Faustus, and Agrippa ... And, at length, I pressed him so hard, that he took himself off through the key-hole in a clap of thunder'. ${ }^{117}$ Lavinia alone retains her head, declaring: 'The reign of the invisible world has passed away with the ages of chivalry and ignorance; the establishment of Sunday schools ... has signed the death-warrant of all ghosts, past, present, and to come; so you will excuse me, if I remain incredulous'. ${ }^{118}$ She finally receives the (rather dubious) reward of claiming the wealthy Nicodemus as her own husband. The Spectre Bridegroom delighted in the weird and wonderful traditions surrounding ghosts, and mocked the solemn, ornate world of gothic with its reference to Latin texts and claps of thunder.

As a final interesting example, consider the letter written by Steven Widcumb to Lady Douglas of Bothwell Castle in 1799. Widcumb explained that he had played the ghost of Hamlet's father in Drury Lane, but was now out of a job. He proposed that as she was 'muche in wante of a Goste to hante your ruinated Cassle', he would be perfectly qualified. He asked for $£ 15$ yearly, and would furnish his own 'windin sheets, chock Lantern, spirit of wine, bludde and all the nessesary apareal for a complite goste, premishing that ife youre Ladishipe wishes at any time a partikulear Goste to friten a partikulear friend you will firnish the dresse'. He added: 'I expect to get my victuales from your owse. I ame in Persin fite for a Goste avin a megir persin, a ollow voice and can grone well when required. P.S. I cane cro like a cok ife requirde'. ${ }^{119}$ Such was the stereotype of the ghost. It could certainly be argued that this detracted from the credibility of ghosts, but it also helped to fix them in the popular imagination.

116 Ibid., act i, scene iii, 16.

117 Ibid., act ii, scene v, 31 .

118 Ibid., act ii, scene ii, 25.

119 Steven Widcumb to Lady Douglas, [1799]: NRS, GD24/5/122. 


\section{Sceptics Meeting Ghosts: The Case of Archibald Pitcairne}

The complex relationship between belief and scepticism is perhaps best demonstrated in the case of Archibald Pitcairne (1652-1713), a well-known Edinburgh physician and Jacobite. Pitcairne, as Wodrow explained, was 'a professed Deist, and by many alledged to be ane Atheist'. ${ }^{120}$ He did not believe in witchoraft, and as we have seen, he mocked Satan's Invisible World Discovered in his coauthored play The Assembly. ${ }^{121}$ Nonetheless, he was said to receive regular visitations from a ghost. ${ }^{122}$ While studying in Paris, he allegedly made a pact with his friend Robert Lindsay that whoever died first should return to the other and explain his condition. Lindsay died in the winter of 1675-6, and the night of his death Pitcairne dreamt that Lindsay came to him. The latter explained that 'they have buried my body in the Gray-Friars, I am, tho', alive and in a place the pleasures of which cannot be exprest in Scots, Greek or Latin. I have come with a well-sayling small ship in Leith Road to carry you thither.' Pitcairne agreed to go on condition that he could take leave of his father, mother and aunt. His friend objected: 'Archie, I have but the allowance of one tide and you shall not make your visit in so short a tyme. Forsooth, Archie, I'll come for you at another tyme.' Pitcairne was said to dream of him every night since, and when he had an illness that seemed fatal, he never feared for himself, as his friend assured him that his time had not yet come.

This account comes from a manuscript examined by John and Winifred MacQueen, who judge it to be in Pitcairne's hand. ${ }^{123}$ The same account was given by Samuel Hibbert, who came across it when David Laing showed him 'several MS. anecdotes relative to [Pitcarine's] family, which are from some one evidently on terms of intimacy with him'. ${ }^{124}$ The story also reached Wodrow's ears, but evidently from different sources. He made several notes about it, each time apparently forgetting the

120 Wodrow, Analecta, ii, 255.

121 See pp. 100-1.

122 See John MacQueen and Winifred MacQueen, 'Introduction', in John MacQueen and Winifred MacQueen (eds.), The Latin Poems (Assen, 2009), 6; John MacQueen and Winifred MacQueen, 'Texts, Translations and Commentaries' in the same volume, 301-3.

123 MacQueen and MacQueen, 'Introduction', 45; John MacQueen, 'Introduction', in John MacQueen (ed.), The Phanaticks (Woodbridge, 2012), xxxii.

124 Hibbert, Sketches of the Philosophy of Apparitions, 211-12. 
previous one. In 1712 he wrote: 'The story of the apparition that Dr Pitcairn is ordinarly haunted with ... is generally belived at Edinburgh; and they tell me the name of the man that appears to him evry night is Lindsay, not Stevenson, as before'. In 1713, writing on Pitcairne's death, he noted: 'There goes a story of ane apparition he had frequently, which he ouned'. In 1723: 'I am told my Lord Grange tells a story, (enquire at him about it) of Dr Pitcairn, that he had an apparition before his death, which signifyed to him the precise day of his death, which came exactly to pass. This he told to some of his comrads a moneth before his death; but could not shake off the apprehension of it. ${ }^{, 25}$ Finally, in 1728 , he gave a full story. He began:

[Lord Grange] acquaints me that the Doctor [Pitcairne] has frequently told him of David (I think Lindsay is his name, if I remember) his constant appearing to him to that time, which was a litle before the Doctor's death. David was Clerk to the Council at Edinburgh, and had been intimat with the Doctor at the Colledge and Schools, and afterwards, and they used very frequently to be together.

In this version of the story, Pitcairne was in Paris when David died in Edinburgh. His dream was as follows:

Just about the time of David's death, as the Doctor afterwards came to knou, that same night the Doctor, at Paris, dreamed he was at Edinburgh, and heard of David's death, and did believe it, but afterwards he met him in the Land-market, and David desired he might go with him: That the Doctor said he was dead, and he would not go with him: That David said it was true his body was dead, and that they had caryed it to the Greyfriers Church-yeard, but he was still alive as much as before, and the Doctor behoved to go with him: That he went doun the street with him with reluctancy, and into severall houses wher they used to drink, but got not acces: That still he importuned the Doctor to go with him, and went doun Leith Wynd, and the Doctor went to Caltoun Craiges, and left him, and sau him go to a ship, and go out of his sight. ${ }^{126}$

Since then, David had appeared to Pitcairne every night. Pitcairne was said to have confirmed the story, and even had a similar one about his sister. There seems to be sufficient evidence to state with some confidence that the story did originate with Pitcairne himself, although clearly it went through enough re-tellings to alter fairly substantially. Of course, since the apparition appeared only in dreams, no

125 Wodrow, Analecta, ii, 379, 47-8.

126 Ibid., iii, 520-2. 
supernatural intervention was strictly necessary. It was implied, however, and it is interesting that Pitcairne should have chosen to talk about the story. John and Winifred MacQueen write that Robert's death and subsequent return had a significant impact on Pitcairne, and 'the state of the dead, posthumous existence in the Underworld and the possibility of return became a recurrent theme' in his poetry. ${ }^{127}$ It may have been fashionable to mock vulgar superstition, and look down on the old lady with her attachment to Satan's Invisible World Discovered, as Pitcairne and Philaretes did eighty years apart. However, publicly professed scepticism did not necessarily preclude experience with ghosts. Pitcairne's case was unusual, but it stands as further evidence that ghosts were relevant to the educated and the illiterate alike.

\section{Conclusion}

Scepticism was an important feature of the eighteenth-century approach to ghosts. There was no room for ghosts in high Enlightenment debates on miracles or the nature of the soul and afterlife. Robert Wodrow and George Sinclair were mainstream figures in late seventeenth-century religious culture; a few decades later there were no comparably established philosophers or theologians arguing that ghosts could prove Christian tenets. In the early decades of the century the sceptics usually recast ghosts as demons, but psychological and physiological theories took over as the century progressed. Ghosts were thus explained in natural, rather than supernatural, terms, and with recourse to science before theology. This speaks to the impact of intellectual change during both the Scientific Revolution and the Enlightenment. However, it does not mean that there was a decline in the cultural importance of ghosts. When ghosts were divorced from their demonic associations there was more freedom for stories to be circulated. Furthermore, as ghosts were a useful vehicle through which to explore new theories about psychological disorders, they became a fashionable subject. In the sixteenth and seventeenth centuries, ghosts were overshadowed by witches, and sometimes also by fairies or second sight

127 MacQueen and MacQueen, ‘Introduction', 6, 35. 
apparitions. While these phenomena were also mentioned in the literature on apparitions and psychological disorders, ghosts were frequently the first point of reference. They took centre stage in the Weekly Magazine's discussion on supernatural beings; the Ghost also demonstrates their popularity. Satirical depictions of ghosts were often scathing, but helped to create and popularise a dramatic, memorable ghost archetype. Amidst the burgeoning print culture of the eighteenth century, ghosts featured more frequently in discussion and emerged as a more easily identifiable cultural trope.

The idea that ghosts were merely a vulgar superstition recurred frequently in eighteenth-century discussion of them. There was something self-congratulatory in this notion; it was used as a means of signalling social superiority. The Scottish class structure was diversifying over the course of the eighteenth century; in the latter half of the century in particular a growing body of urban professionals came to constitute a new (or, at least, newly important) middle class. ${ }^{128}$ Arguably, as old class divides based on noble lineage became less important, there was more value in drawing cultural distinctions. The Union with England also fostered a drive among fashionable Scotsmen to distance themselves from their nation's perceived backwardness. ${ }^{129}$ However, the sceptics' clean divide between educated and vulgar culture was misleading. Ghost belief lingered on in elite culture - potentially even among folk who were publicly perceived as sceptics. Ghosts retained enough credibility to appear before courts and kirk sessions, and perpetrating ghost hoaxes or spreading false stories of ghosts was taken seriously as an offence. Moreover, debate in periodicals indicates that there were still plenty of educated folk ready to defend ghosts, employing arguments that were popular a hundred years previously. As many of the sceptics pointed out, ghosts thrived in the imagination; it is possible that there was no such thing for them as bad publicity. We shall return to the questions of belief and division between popular and elite culture. The sceptics, for all their assurance, do not offer definitive answers.

128 See, for example, Stana Nenadic, 'The Rise of the Urban Middle Classes', in Tom M. Devine and Rosalind Mitchison (eds.), People and Society in Scotland, Vol. 1: 1760-1830 (Edinburgh, 1998); David Allan, Scotland in the Eighteenth Century: Union and Enlightenment (Harlow, 2002), 10818.

129 This theme is explored more fully in the next chapter. 


\section{Ghosts in Fiction and Antiquarian Studies}

Historical studies of ghost beliefs often leave aside the world of fiction. This tendency is regrettable. Literature may be outside of the traditional domain of the historian, but it offers an important window into contemporary views on ghosts. Moreover, literary works played a crucial role in developing new conceptions of the ghost in eighteenth- and early nineteenth-century society. Over this period, especially the latter half of it, the world of fiction evolved rapidly. New genres emerged, particularly gothic and romanticism, which brought supernatural themes into mainstream literary culture. There was also a dramatic expansion of the publishing industry and an increase in venues such as theatres, which allowed stories to reach ever-broadening audiences. A new kind of ghost emerged, valued more for its aesthetic qualities than its religious import. This chapter identifies two broad trends in the literary presentation of Scottish ghosts. By the first of these trends, ghosts became a short-cut into an uncanny world, and reflected on universal themes such as fear, madness and death. In contrast, the second trend saw ghosts tied to a specifically Scottish present and past: they were employed to celebrate Scottish folk culture and evoke the watchful presence of older generations. The ghosts of the first category tend to be closely aligned with motifs and techniques found in works of gothic horror, while those of the second category are more obviously related to the romantic project of nation-building. However, this is not to imply that gothic and romanticism were clear-cut categories; as we shall see, the terms are difficult to define and there are plenty of areas of overlap. This chapter is concerned more with the ways in which ghosts were used than the labels that should be attached to them.

There is another reason that historians should give some thought to literary ghosts: as noted in the introduction, it is impossible to cleanly separate them from their nonfictional counterparts. This period also saw the evolution of folklore. In theory, folklorists recorded what Linda Dégh has termed a legend - that is, a tale that was 
believed to be rooted in truth. ${ }^{1}$ Theoretically, this was a distinct genre from the inventions offered as fiction in magazines or other publications. In practice the barrier often fell down. John Mackay Wilson's Tales of the Borders (1834-40) is an example of a series that collected 'historical, traditionary and imaginative' stories, without generally distinguishing between the categories. Figures such as Walter Scott and James Hogg wove traditional legends into their fictional writing, while the poems of Ossian were fiction masquerading as folklore. Antiquarian studies used ghosts to develop and promote a certain image of Scotland, just as did romantic fiction. This chapter will also, therefore, discuss the evolution of folkloric research in the eighteenth and early nineteenth centuries. Overall, the focus of the chapter is on the ways in which ghosts were depicted and employed by fiction-writers, folklorists and those who straddled both categories.

\section{Developments in the Literary World}

As noted above, the eighteenth and early nineteenth centuries saw the birth of gothic and romantic fiction. Much ink has been spilled in the endeavour to provide a precise definition of these two terms. It is beyond the scope of this chapter to journey far into this territory, but a brief survey may be useful, as the concepts will recur frequently. To begin with gothic, the current scholarly consensus is that there is no single, clearly identifiable essence. Instead gothic is viewed as a 'conglomeration of literary "kinds", a 'discursive site', an 'atmosphere' or 'aesthetic'. ${ }^{2}$ The recent trend has been to avoid even listing usual features of gothic, to guard against any implication that gothic has a 'static identity' or was produced in a formulaic fashion (as its eighteenth-century critics suggested). ${ }^{3}$ Nevertheless, certain elements have been highlighted as common (although not universal or exclusive) components of the

1 Linda Dégh, Legend and Belief: Dialectics of a Folklore Genre (Bloomington, 2001), ch. 2.

2 R. L. Platzner, quoted in Robert F. Geary, The Supernatural in Gothic Fiction: Horror, Belief, and Literary Change (Lewiston [N.Y.], 1992), 2; Robert Miles, Gothic Writing, 1750-1820: A Genealogy, 2nd edn (Manchester, 2002), 4; E. J. Clery, The Rise of Supernatural Fiction, 17621800 (Cambridge, 1995), 90; Andrew Smith, Gothic Literature (Edinburgh, 2007), 4; Michael Gamer, Romanticism and the Gothic: Genre, Reception, and Canon Formation (Cambridge, 2000), 4.

3 Gamer, Romanticism and the Gothic, 9. 
gothic aesthetic. These elements include an antiquarian taste for old ruins, castles, and monasteries; an interest in insanity and sadism; the use of supernatural themes; a 'preference for the style or affective state called sublimity'; and the condition of 'rupture, disjunction, fragmentation'. ${ }^{4}$

While the definition of gothic remains problematic, its historical trajectory is clearer. Horace Walpole's The Castle of Otranto, published in 1764, is generally credited with being the first gothic novel. Writing in 1811, Walter Scott praised Walpole for having helped to rehabilitate the term 'Gothic', which was 'used before his time to express whatever was in pointed and diametrical opposition to the rules of true taste'. ${ }^{5}$ These negative associations never fully disappeared; gothic was often considered to have little true literary value, and was frequently thought of as a women's genre. ${ }^{6}$ Even by 1824 , one commentator felt the need to emphasise that 'whatever small men, accustomed to move in one very small sphere of intellect, may say, the horrible is quite as legitimate a field of poetry and romance, as either the pathetic or the ludicrous'. ${ }^{7}$ Nonetheless, gothic's blend of horror, romance and melodrama captured the popular imagination. The 1790s in particular were a heyday for the genre, seeing the publication of two vastly influential works: Ann Radcliffe's The Mysteries of Udolpho (1794) and Matthew Lewis's The Monk (1796). Charles Maturin's Melmoth the Wanderer (1820) was another important work, but thereafter the genre declined, although gothic themes re-emerged in various Victorian subgenres. ${ }^{8}$ In the case of Scotland specifically, it is generally argued that gothic did not emerge until the nineteenth century, with the work of Walter Scott, James Hogg and the 'tales of terror' printed in Blackwood's Edinburgh Magazine. ${ }^{9}$ Nevertheless, as

4 Smith, Gothic Literature, 4; Francis R. Hart, quoted in Geary, Supernatural in Gothic Fiction, 3; Miles, Gothic Writing, 3.

5 Walter Scott, 'Introduction', in Horace Walpole, The Castle of Otranto: A Gothic Story (Edinburgh, 1811), vi.

6 In Scott's 'Aunt Margaret's Mirror', Aunt Margaret recounts the symptoms of enjoyment of a good ghost story, but adds: 'I mean such are signs which indicate the crisis, when a female imagination is in due temperature to enjoy a ghost story. I do not pretend to describe those which express the same disposition in a gentleman.' Walter Scott, 'My Aunt Margaret's Mirror', in Frédéric Mansel Reynolds (ed.), The Keepsake for 1829 (London, 1828), 11.

7 'The Devil's Elixir', Blackwood's Edinburgh Magazine, July 1824, 55.

8 See Geary, Supernatural in Gothic Fiction, esp. 12.

9 Ian Duncan, 'Walter Scott, James Hogg and Scottish Gothic', in David Punter (ed.), A New Companion to the Gothic (Oxford, 2012), 123. See also David Punter, 'Scottish and Irish Gothic', in Jerrold E. Hogle (ed.), The Cambridge Companion to Gothic Fiction (Cambridge, 2002). 
we shall see, motifs that would later be associated with gothic were appearing in Scottish literature from at least the mid-eighteenth century. The recent scholarly emphasis on the fluidity of gothic justifies a more liberal use of the term: my focus will be on gothic themes, rather than on gothic texts.

Romanticism is the other thorny term employed in this chapter. Gothic has often been presented as a subset of romantic fiction, but Michael Gamer's detailed comparison rejects this reading, arguing instead that romanticism developed 'as a response to gothic's reception' and was framed as a form of 'high culture' in contrast to gothic's popularism. ${ }^{10}$ In Scotland there was certainly a significant amount of overlap between gothic and romantic authors and works, but romanticism does not share gothic's association with themes of fear, displacement, madness and malevolence - or, to recall the more succinct phrasing of our 1824 commentator, 'the horrible'. It is, however, harder to say what Scottish romanticism was than what it was not. The European romantic movement is generally thought to have originated in Germany in the last decade of the eighteenth century. ${ }^{11}$ However, studies of Scottish romanticism tend to begin earlier, with the Ossian poetry in the 1760 s or the work of Allan Ramsay in the early eighteenth century. ${ }^{12}$ To talk of Scottish romanticism, therefore, is not necessarily to talk of Scotland within the romantic era, or at least not the romantic era as defined by historians working on England or Europe as a whole. To complicate the picture further, some critics have questioned whether a genuine Scottish romanticism existed at all. This viewpoint is summarised (and later challenged) by Ian Duncan, Leith Davis and Janet Sorensen:

Scotland ... stands for an inauthentic Romanticism, defined by a mystified purely ideological - commitment to history and folklore. Rather than be a site of Romantic production, Scotland's fate is to have become a Romantic object or

10 Gamer, Romanticism and the Gothic, 4-5, 10.

11 See, for example, Marilyn Butler, 'Romanticism in England', in Roy Porter and Mikuláš Teich (eds.), Romanticism in National Context (Cambridge, 1988), 38; Michael Ferber, 'Introduction', in Michael Ferber (ed.), A Companion to European Romanticism (Oxford, 2005), as well as other essays in these volumes.

12 Fiona Stafford, 'Scottish Romanticism and Scotland in Romanticism', in Michael Ferber (ed.), $A$ Companion to European Romanticism (Oxford, 2005); Murray Pittock, Scottish and Irish Romanticism (Oxford, 2008), ch. 2. See Pittock's discussion of the dating of Scottish romanticism in this work, $1-3$. 
commodity ... a series of kitsch, fake, more or less reactionary 'inventions of tradition,' from Ossian and Scott to Flora MacLeod and Brigadoon. ${ }^{13}$

In addition, the Scottish Enlightenment has frequently been emphasised at the expense of a Scottish romantic movement. As Murray Pittock outlines, the Enlightenment has been presented as the antithesis to romanticism, championing rationality at the expense of imagination, and focusing on social development while the romantics celebrated 'the primitive and isolated person'. ${ }^{14}$

Recent scholarship has challenged these ideas, highlighting the ways in which Enlightenment thought complemented romantic production. ${ }^{15}$ In addition, there has been a tendency to move away from questions of authenticity. Katie Trumpener's 1997 Bardic Nationalism was the first in a line of works to take a more sympathetic view of Scottish romanticism. Instead of objecting that romantic authors did not accurately depict a Scottish past, recent historians have instead examined how they re-imagined this past and used it to create new models of national identity, '[reconceiving] national history and literary history under the sign of the bard'. In this reading, anachronism becomes 'one of the constitutive tropes of a distinctive practice of Romantic historicism'. ${ }^{16}$ The literary recreation of Scotland's past thus emerges as one of the features at the heart of a national romanticism. ${ }^{17}$ As we shall see, ghosts played an important part in this enterprise, and offer interesting reflections on the question of authenticity.

Another significant development in this period was the evolution of venues and production methods that allowed literary works to reach a wider audience. The Union

13 Ian Duncan, Leith Davis, and Janet Sorensen, 'Introduction', in Leith Davis, Ian Duncan, and Janet Sorensen (eds.), Scotland and the Borders of Romanticism (Cambridge, 2004), 1.

14 Murray Pittock, 'Enlightenment, Romanticism and the Scottish Canon', in Gerard Carruthers and Liam McIlvanney (eds.), The Cambridge Companion to Scottish Literature (Cambridge, 2012), 88.

15 Ibid., 88-101; Murray Pittock, 'Introduction: What Is Scottish Romanticism?', in Murray Pittock (ed.), The Edinburgh Companion to Scottish Romanticism (Edinburgh, 2011), 6-9; Duncan, Davis, and Sorensen, 'Introduction.'

16 Katie Trumpener, Bardic Nationalism: The Romantic Novel and the British Empire (Princeton, 1997), xii; James Chandler, quoted in Duncan, Davis, and Sorensen, 'Introduction', 10.

17 See Pittock, 'Introduction', as well as the introduction to Pittock, Scottish and Irish Romanticism, for a much fuller consideration of the factors that constitute a national romanticism. 
created more economic opportunities for Scottish booksellers. Enlightenment culture also boosted print production; Richard Sher has identified an 'Enlightenment publishing revolution' in the second half of the century. There was a flourishing of shops, circulating libraries, publishing houses, literary periodicals and discussion groups. ${ }^{18}$ Rapid development continued over the first three decades of the nineteenth century, a period that has been termed the 'golden age' of Scottish publishing. ${ }^{19}$ Output was not limited to Enlightenment scholarship. Gerard Carruthers describes the 'invention of Scottish literature' in the long eighteenth century, and the early nineteenth century saw the emergence of the novel as an important art form, with Walter Scott as the trailblazer. ${ }^{20}$ Regarding ghosts specifically, one particularly significant milestone was the founding of Blackwood's Edinburgh Magazine in 1817. Set up by the publisher William Blackwood as a Tory rival to the Whigs' Edinburgh Review, Blackwood's interested itself in antiquarianism, vernacular poetry and sensationalist fiction. It stood on the cutting edge of Scottish literary production, with James Hogg and Walter Scott among its frequent contributors, and it swiftly established a wide audience. Ghosts appeared frequently in the pages of Blackwood's, with the 'tale of terror' emerging as a sort of subset of gothic, which both embraced and subverted the conventions of the genre. ${ }^{21}$

Furthermore, ghosts increasingly appeared on Scottish stages from the late eighteenth century. The Reformation kirk has traditionally been accused of suppressing all kinds of dramatical production prior to this period. In fact, as several historians have

18 Richard B. Sher, The Enlightenment and the Book: Scottish Authors and Their Publishers in Eighteenth-Century Britain, Ireland, and America (Chicago, 2007), 1-2, 608; Robert Crawford, Scotland's Books (London, 2007), 330; Bill Bell, 'The Scottish Book Trade at Home and Abroad, 1707-1918', in Ian Brown et al. (eds.), The Edinburgh History of Scottish Literature, Vol. 2: Enlightenment, Britain and Empire (1707-1918) (Edinburgh, 2007), 221-2.

19 Crawford, Scotland's Books, 388; Bell, 'Scottish Book Trade', 223-4; Peter Garside, 'Publishing 1800-30', in Bill Bell (ed.), The Edinburgh History of the Book in Scotland, Vol. 3: Ambition and Industry 1800-1880 (Edinburgh, 2007).

20 Gerard Charles Carruthers, 'The Invention of Scottish Literature during the Long Eighteenth Century' (University of Glasgow PhD thesis, 2001); Ian Duncan, Scott's Shadow: The Novel in Romantic Edinburgh (Princeton, 2007).

21 Robert Morrison and Daniel S. Roberts, “"A Character so Various, and yet so Indisputably Its Own”: A Passage to Blackwood's Edinburgh Magazine', in Robert Morrison and Daniel S. Roberts, (eds.), Romanticism and Blackwood's Magazine: 'An Unprecedented Phenomenon" (Basingstoke, 2013), as well as other essays in this volume; Duncan, 'Walter Scott, James Hogg and Scottish Gothic', 132-3; Tim Killick, British Short Fiction in the Early Nineteenth Century: The Rise of the Tale (Aldershot, 2008), 24-6; Duncan, Davis, and Sorensen, 'Introduction', 13. 
shown, the picture was somewhat more complicated. Drama survived within folk culture and at court, religious plays were produced for some years, and some plays were exported to Europe if not performed in Scotland..$^{22}$ Nonetheless, the kirk did place significant limitations on dramatic productions, and Scottish theatre also suffered from monarchical instability in the sixteenth century and the removal of the royal court in the seventeenth. ${ }^{23}$ A turning point came in 1767 , when a patent was granted for the Theatre Royal in Edinburgh, Scotland's first professional theatre. Adrienne Scullion writes that 'despite religious opposition, a theatre culture was established and a wildly enthusiastic, increasingly knowledgeable and eminently partisan audience quickly developed'. By 1800 there were nine permanent playhouses across Scotland. ${ }^{24}$

Shakespeare's use of ghosts ensured that they would never be strangers to the early modern stage. However, prior to the second half of the eighteenth century, Shakespeare was rarely seen in Scottish theatres. Only one edition of a Shakespeare play (Venus and Adonis) seems to have been published in Scotland before 1752. In the second half of the eighteenth century, Scottish editions of Shakespeare began to appear frequently, and early nineteenth-century playbills reveal frequent Shakespearean performances. ${ }^{25}$ As Shakespeare's ghosts made their way on to Scottish stages, they were joined by others. Before a 1762 performance of The Haunted House, a prologue declared:

If in this wise, this wonder-working age, We bring a Ghost upon the Scottish stage, No cynic sure, will treat with ill-tim'd passion

22 See Ian Brown, Scottish Theatre: Diversity, Language, Continuity (Amsterdam, 2013), ch. 4; Sarah Carpenter, 'Scottish Drama until 1650', in Ian Brown (ed.), The Edinburgh Companion to Scottish Drama (Oxford, 2011).

23 Bill Findlay, 'Beginnings to 1700', in Bill Findlay (ed.), A History of Scottish Theatre (Edinburgh, 1998), 15, 55, 60; Sarah Carpenter, 'Early Scottish Drama', in R. D. S. Jack (ed.), The History of Scottish Literature, Vol. 1: Origins to 1600 (Aberdeen, 1988), 199, 210.

24 Adrienne Scullion, 'The Eighteenth Century', in Bill Findlay (ed.), A History of Scottish Theatre (Edinburgh, 1998), 80.

25 Andrew Murphy, 'Shakespeare Goes to Scotland: A Brief History of Scottish Editions', in Willy Maley and Andrew Murphy (eds.), Shakespeare and Scotland (Manchester, 2004), 157-60; Playbills of the Theatre Royal Edinburgh (NLS), http://digital.nls.uk/playbills/index.html, accessed 1 Aug. 2015. 
The universal vogue, the reigning fashion $!^{26}$

It noted the popularity of the Cock Lane Ghost in London,

whose modes you all admire,

Whose very foibles set your souls on fire

and added that ghosts contributed to the comedy of a play. ${ }^{27}$ Ghosts were also seen as valuable dramatic devices. George MacLaurin's Laura, or the Punishment of Perfidy (published in 1812, ten years after the author's death) tells of a young woman, Laura, who is seduced by her guardian Lord Albert. The editor 'improved' the play (as he explained it) by inserting a rather incongruous scene at the beginning of the second act. While Albert sleeps, he is visited by the shrouded ghost of Laura's mother. She wields a dagger and explains that she had been deputed from above to chastise him with 'the cutting scourge of gnawing conscience'. She warns him to beware of both her dagger and her daughter, presaging the culmination of the play in which Albert is stabbed by Laura. ${ }^{28}$ Besides this dramatic foreshadowing, the ghost serves little function; Albert is already beset with guilt before her visit. The editor clearly considered a ghost to be a proper complement to a dramatic tragedy.

Plays which featured ghosts (or, at least, supposed ghosts) seemed to have been performed with reasonable frequency from the late eighteenth century. Allan Ramsay's 1725 The Gentle Shepherd (discussed further below) was very popular. ${ }^{29}$ Playbills from the 1820s feature Hamlet, Macbeth and Richard III alongside titles such as The Libertine; or, The Feast of the Spectre; Der Freischutz; or, The Spectre Huntsman of Bohemia; Banditti of Rosenwald; or, The Spectre of the Bleeding Nun and The Spectre Bridegroom (the latter being the satirical piece we encountered in

26 Quoted in John Jackson, The History of the Scottish Stage, from Its First Establishment to the Present Time (Edinburgh, 1793), Appendix V, 17.

27 Ibid., 17-18.

28 George MacLaurin, 'Laura, Or, the Punishment of Perfidy', in Colin MacLaurin and George MacLaurin, The Poetical and Dramatic Works of Colin Maclaurin, Esq. Advocate, and of the Late George Maclaurin, Esq. Writer, 2 vols. (Edinburgh, 1812), i, act ii, scene i, 101-2, and editor's note, 94.

29 Scullion, 'Eighteenth Century', 93. 
the previous chapter). ${ }^{30}$ Little is recorded about how these ghosts were actually presented on stage, but a few tidbits survive. In England the actors often wore white sheets, and their faces were whitened with flour. ${ }^{31}$ An exception was made for the ghost of Hamlet's father, who appeared in full armour. In the late 1790s Stuart Moncrieff Threipland wrote to the editor of the Scots Chronicle about performances at the Theatre Royal, Edinburgh. He expressed his belief that it was a big improvement to have ghosts walking on and off the stage instead of using trapdoors. $^{32}$ John Jackson explained how, when the ghost of Hamlet's father appeared, Hamlet's hat was made to fly off 'by the usual stage trick'. Sometimes lights would be made to burn blue, in keeping with the tradition that flames burned blue if a ghost were present. ${ }^{33}$ These snippets suggest that ghosts had their own set of stage conventions, sensational trappings that set them aside from the other characters of a piece. Both through print culture and the stage, therefore, the eighteenth and early nineteenth centuries saw ghosts marketed in new and alluring ways. As we shall see, they also took on a range of new meanings.

\section{II 'In grim Array the grizly Spectres rise'}

As noted above, the development of Scottish gothic is generally associated with the early nineteenth century. However, Hamish Mathison has argued that gothic themes and techniques were used in Scotland from the early eighteenth century, with the work of Allan Ramsay marking the appearance of "a "gothic" writing, where the gothic is understood as "the realm within literature that imagines and utilises the supernatural as a constrained and contained terror." 34 The idea that Ramsay used ghosts in this fashion (as Mathison suggests) is questionable. Ramsay’s ghosts tended

30 Playbills of the Theatre Royal Edinburgh. See pp. 139-40.

31 Stanley Wells, 'Staging Shakespeare's Ghosts', in Murray Biggs (ed.), The Arts of Performance in Elizabethan and Early Stuart Drama (Edinburgh, 1991), 51; Michael Hattaway, Elizabethan Popular Theatre: Plays in Performance (London, 1982), 85.

32 Stuart Moncrieff Threipland, Letters Respecting the Performances at the Theatre Royal, Edinburgh (Edinburgh, 1800), 19.

33 Jackson, History of the Scottish Stage, 339, 18.

34 Hamish Mathison, 'Gothic Poetry in Scotland: The Ghaistly Eighteenth Century', Gothic Studies, xiv (2012), 40. 
to be farcical examples of popular superstitions, or vehicles for political commentary (as we shall see). His work lacked the elements of horror and melodrama that were to characterise gothic's supernaturalism. However, the use of ghosts as a 'constrained and contained terror' did emerge in Scottish literature before the nineteenth century. Robert Blair (1699-1746) is a more obvious starting point. Blair is chiefly remembered for 'The Grave', a blank verse poem that was published in 1743. It was one of the forerunners of the 'graveyard school' of poetry, which emerged around the middle of the eighteenth century and fed into the development of gothic. ${ }^{35}$ Casting his eye over a churchyard, Blair describes a lugubrious atmosphere, with ghosts drifting from the gloomy vaults:

In grim Array the grizly Spectres rise,

Grin horrible, and, obstinately sullen

Pass and repass, hush'd as the Foot of Night. ${ }^{36}$

The ghosts he presents have no purposes, no ties to a pre-death mortal self, and little religious significance. They are primarily atmospheric figures. Blair's language emphasises their unsettling appearance above all: note the jarring alliteration and assonance of 'grim', 'grisly' and 'grin'. Blair was a Presbyterian minister, and 'The Grave' took an evangelistic tone, expounding the evils of the 'Foul Monster, Sin!', celebrating Christ as 'Th' illustrious Deliverer of mankind', and describing death as 'Our Bane turn'd to a Blessing!' ${ }^{37}$ Nevertheless, his ghosts were not the Christian moralists favoured by Wodrow or Sinclair.

Blair's ghosts reflect a broader trend in eighteenth century religious culture. Printed funeral sermons declined, and instead there was a rise of poetry dealing with death. Eric Parisot explains that poetry increasingly reclaimed authority from traditional religious texts, echoing a 'general trajectory during the early to mid-eighteenth century from the religious to the aesthetic'. ${ }^{38}$ Scotland saw the introduction of toleration for Episcopalians in 1712, followed by the accession of the Moderates in

35 See Eric Parisot, Graveyard Poetry: Religion, Aesthetics and the Mid-Eighteenth-Century Poetic Condition (Farnham, 2013).

36 Robert Blair, The Grave: A Poem (London, 1743), 11. 40-2, p. 5.

37 Ibid., 1. 600, p. 31; 1. 668, p. 35; 1. 710, p. 37.

38 Parisot, Graveyard Poetry, 20. 
the 1760s. This reduced the importance of precise theological disputes, and left more scope for alternative means of religious exploration. ${ }^{39}$ Nonetheless, religion and romantic literature had a troubled relationship. Crawford Gribben has written of how both the Evangelical and Moderate parties of the eighteenth-century church are associated with 'anti-aesthetic instincts', and argues that Scottish Evangelicals were 'generally suspicious of creative writing across the genres' well into the nineteenth century. ${ }^{40}$ These tensions are apparent in Blair's work. The earliest surviving draft of the poem contained the following lines:

Where light-heel'd Ghosts, and visionary Shades Unbody'd, thick, beneath the wan Cold Moon

Solemnly Stalking in her lone sojourn:

Glide by Each Other, in Imperiall Silence;

In the final, published version these lines were altered:

Where light-heel'd Ghosts, and visionary Shades, Beneath the wan cold Moon (as Fame reports)

Embody'd, thick, perform their mystick Rounds. ${ }^{41}$

The insertion of 'as Fame reports' distanced Blair himself from ghost belief. Blair was working within a religious framework, and 'The Grave' grew out of a midcentury fashion for a dramatic, mournful style of piety that saw graveyard poetry used as an aid to private worship. ${ }^{42}$ However, there were fundamental problems when it came to reconciling the poetic ghost with religious orthodoxy. Looking at the picture in France, where there was a similar literary trend in the eighteenth

39 David Allan, Virtue, Learning and the Scottish Enlightenment: Ideas of Scholarship in Early Modern History (Edinburgh, 1993), 8-9; David Allan, Scotland in the Eighteenth Century: Union and Enlightenment (Harlow, 2002), 63-7. More broadly see Thomas Ahnert, The Moral Culture of the Scottish Enlightenment, 1690-1805 (New Haven, 2014); Richard B. Sher, Church and University in the Scottish Enlightenment: The Moderate Literati of Edinburgh (Edinburgh, 1985); John R. McIntosh, Church and Theology in Enlightenment Scotland: The Popular Party, 17401800 (East Linton, 1997); Andrew Landale Drummond and James Bulloch, The Scottish Church, 1688-1843: The Age of the Moderates (Edinburgh, 1973).

40 Crawford Gribben, 'Religion and Scottish Romanticism', in Murray Pittock (ed.), The Edinburgh Companion to Scottish Romanticism (Edinburgh, 2011), 118, 119.

41 Blair, 'The Grave', 11. 14-17 (first draft) and 11. 24-6 (published version), quoted in J. A. Means, 'The Composition of The Grave', Studies in Scottish Literature, x (1972), 4, 6; Parisot, Graveyard Poetry, 62.

42 Parisot, Graveyard Poetry, 4, 14. 
century, John McManners suggests that the romanticised ghost could only really develop at the expense of religious interests: 'Perhaps, as religious themes ceased to be the staple subjects of artistic inspiration, a place was left which had not been available before, for the "gliding spectre and the groaning grave" and the harsh and haunting beauties of Nature'. ${ }^{43}$

Certainly, as gothic themes developed further in Scottish literature, religion was left by the wayside. Ghosts appeared without disclaimers like Blair's 'as Fame reports', and as in 'The Grave', their aesthetic features took centre stage. Ghosts were 'light of foot as any sprite', came 'upon the wings of night' and glided 'like a feeble beam of light'. ${ }^{44}$ They had voices 'like thunder'. ${ }^{45}$ Some ghosts had an ethereal beauty to them. The play The Ghost of the Oratory (1825) presents a 'ghost' who later proves to be a living woman. However, far from being a comical figure drowning in a white sheet, she is depicted with a poetic grandeur. She appears as a gliding figure with cold flesh, lifeless eyes, and a 'silky silent' step. Her 'light loose lawny vestement' is 'silver'd' with 'Heaven's gleam', and her young beholder, recounting the scene, remembers:

Fear's chill damp

Impearl'd my brow,

-but yet my quivering lip

Burn'd with that queen-like ghost's so marvellous beauty. ${ }^{46}$

Other ghosts were more gruesome. James Beattie wrote of ghosts who 'glare[d] horrid from the sylvan gloom', while James Graeme's spectres flocked forth from their 'restless graves' at midnight and stalked 'in melancholy state', baring their gaping wounds. ${ }^{47}$ Ghosts were 'lonely' figures, pale and shivering, fearful of light.

43 John McManners, Death and the Enlightenment: Changing Attitudes to Death Among Christians and Unbelievers in Eighteenth-Century France (Oxford, 1981), 335.

44 'The Genius of Caledonia: A Poem on the Threatened French Invasion', Edinburgh Magazine, or Literary Amusement, June 1798, 464; Charles Kerr, 'Maria: An Irregular Ode', Juvenile Performances in Poetry (Edinburgh, 1788), sec. vii, 66.

45 Patrick Gordon, The Famous History of the Renown'd and Valiant Prince, Robert Sirnamed, the Bruce, King of Scotland, \&c (Edinburgh, 1718), bk. i, 34.

46 'The Ghost of the Oratory', Blackwood's Edinburgh Magazine, Oct. 1825, scene iv, 446-7.

47 James Beattie, 'Ode to Peace', Original Poems and Translations (London, 1760), sec. iii:2, 7; James Graeme, 'Elegy XVIII' and 'Elegy XXIV', Poems on Several Occasions (Edinburgh, 1773), 177, 189. 
They usually wore white, often white shrouds. ${ }^{48}$ They generally haunted tombs and churchyards, but at night time could be expected anywhere lonely and solitary, with a particular penchant for old buildings such as castles. Tobias Smollett presented a typical elegy:

I'll seek some lonely church, or dreary hall

Where fancy paints the glimmering taper blue,

Where damps hang mouldering on the ivy'd wall,

And sheeted ghosts drink up the midnight dew; ${ }^{49}$

Ghosts of this sort appeared frequently in Blackwood's and other periodicals, as well as on the stage. One of the aforementioned playbills advertises Banditti of Rosenwald; or, The Spectre of the Bleeding Nun. This piece was described as a melodrama, and was based on the sub-plot of Matthew Gregory Lewis's The Monk (1796). The Monk tells the story of Raymond, Marquis de las Cisternas, who falls in love with Agnes, the niece of the Baroness of Lindenberg. Agnes is destined for a convent, however, and the two resolve to elope. As Agnes is under close guard, they plan to disguise her as the Bleeding Nun, a ghost who appears on the 5 May every five years. However, Raymond ends up eloping with the actual ghost by mistake. He later learns that the ghost murdered her old lover, and was then killed herself. She haunts Raymond until he finds and buries her bones. This was a ghost from one of the archetypal gothic works, with a tragic back-story of doomed love and a ritualistic and dramatic mode of appearing. By the nineteenth century this romanticised vision of the ghost was common fictional fodder.

While the ghost in the Banditti of Rosenwald had a central role in the plot, many ghosts followed the pattern seen in 'The Grave', appearing primarily as atmospheric devices. J. A. Means has suggested that this reflects the declining importance of the ghost: 'It is interesting to note that, as Englishmen ceased to believe in ghosts, the

48 Gallovidiensis, 'Elegy to the Memory of Miss Dick', Edinburgh Magazine, or Literary Miscellany, Apr. 1796, 304; Tobias Smollett, 'Ode to Mirth', Plays and Poems Written by T. Smollett, M. D. (London, 1777), 251; William Erskine, Epistle from Lady Grange to Edward D-, Esq. (London, 1798), 20; John Tait, 'The Vanity of Human Wishes, an Elegy, Occasioned by the Untimely Death of a Scots Poet', in Robert Fergusson, Poems on Various Subjects, by Robert Fergusson, Part II (Edinburgh, 1779), 149.

49 Tobias Smollett, The Adventures of Roderick Random, 2 vols. (London, 1748), ii, 272. 
place of spirits in serious literature was reduced from that of agents (e.g., Hamlet and Macbeth) to that of a picturesque element in the background of the action, as in The Grave and late eighteenth-century poetry generally'. ${ }^{50}$ Setting aside the question of whether or not people were ceasing to believe in ghosts, there are two problems with this reading. Firstly, ghosts were still used as agents. Means might not have allowed Banditti of Rosenwald to be 'serious literature', but a more convincing argument can be made for the work of Joanna Baillie (1762-1851), which constitutes an important stepping stone in the development of Scottish gothic. ${ }^{51}$ In Baillie's 1790 poem 'Night Scenes of Other Times', a woman called Margaret sets out on a stormy night to meet her beloved Edward. Edward, however, has been murdered, and Margaret is met by his ghost. She opts to join him in the tomb, and dies on the spot. Subsequently, Edward's ghost appears to his murderer, pale and bloody, a blade still in his heart, eyes 'dark and dreadful'. He does not speak, but makes such an impression that his murderer is haunted with 'gloomy fears' for the rest of his days. ${ }^{52}$ Margaret herself bids a post-mortem goodbye to her grieving father through ghostly harp music. These ghosts are protagonists, rather than mere atmospheric devices.

Even when ghosts did remain in the background, they were more than a mere 'picturesque element'. Ghosts pervaded scenes with a sense of horror. This alone could influence - or even dictate - the action of a piece. Both Blair and Baillie wrote of figures (a schoolboy and a soldier, respectively) walking through churchyards only to be overtaken by fear. The atmosphere of the graveyard fills the characters with mounting dread, as both remember ghost stories they have been told. In the case of Baillie's soldier:

Swift to his thoughts, unbidden, throng

Full many a tale, forgotten long,

Of ghosts, who at the dead of night

Walk round their graves all wrapt in white,

And o'er the church-yard dark and drear,

50 Means, 'Composition of The Grave', 6n11.

51 See the essays in Thomas C. Crochunis (ed.), Joanna Baillie, Romantic Dramatist: Critical Essays (London, 2004).

52 Joanna Baillie, 'Night Scenes of Other Times', Poems: Wherein It Is Attempted to Describe Certain Views of Nature and of Rustic Manners (London, 1790), pt. ii, 46, 48. 
Becken the traveller to draw near: $:^{53}$

The man, overcome with terror, collapses. Blair's schoolboy is similarly frightened, and flees, only to make new stories himself:

Sudden! he starts, and hears, or thinks he hears

The Sound of something purring at his Heels:

Full fast he flies, and dares not look behind him,

Till out of Breath he overtakes his Fellows;

Who gather round, and wonder at the Tale

Of horrid Apparition, tall and ghastly, ${ }^{54}$

Ghosts, therefore, could wield significant power without even having to make appearances. This foreshadows the psychological horror that would become an important feature of gothic. Fred Botting explains:

In the period dominated by Romanticism, gothic writing began to move inside, disturbing conventional social limits and notions of interiority and individuality. The internalisation of gothic forms represents the most significant shift in the genre, the gloom and darkness of sublime landscapes becoming external markers of inner mental and emotional states. ${ }^{55}$

As we saw in the last chapter, in the latter half of the eighteenth century there was a move towards interpreting ghosts as the products of psychological disorders. Terry Castle has written insightfully of how this broader process played into the world of gothic fiction, with the internalisation of ghosts resulting in the 'supernaturalizing of the mind itself ${ }^{56}$ For writers, this offered an opportunity to explore the power of the supernatural without condoning it. Smollett provides an early example of this approach. In The Adventures of Ferdinand Count Fathom (1753) he plays with the power of the psychological ghost, torturing his hero with ominous scenes:

53 Joanna Baillie, 'To Fear', Poems: Wherein It Is Attempted to Describe Certain Views of Nature and of Rustic Manners (London, 1790), 141.

54 Blair, The Grave, 11. 63-8, p. 7.

55 Fred Botting, Gothic: The New Critical Idiom, 2nd edn (Abingdon, 2014), 83-4. See also Geary, Supernatural in Gothic Fiction.

56 Terry Castle, The Female Thermometer: Eighteenth-Century Culture and the Invention of the Uncanny (Oxford, 1995), 159-89 (quotation 161). 
The darkness of the night, the silence and solitude of the place, the indistinct images of the trees that appeared on every side, 'stretching their extravagant arms athwart the gloom,' conspired ... to disturb his fancy, and raise strange phantoms in his imagination. Although he was not naturally superstitious, his mind began to be invaded with an awful horror, that gradually prevailed over all the consolations of reason and philosophy. ${ }^{57}$

This theme is explored more fully in Alexander MacDonald's play Vimonda (first performed 1787, first printed the following year). The eponymous heroine is tormented by sightings of her father's ghost. The rational hero Melville, her lover, assures her that the ghost is no more than

the creature of thy fancy,

Work'd up to phrenzy by sad thoughts and solitude. ${ }^{58}$

However, living in a continual state of fear shatters Vimonda's nerves. Even after the ghost proves to be her still-living father, Vimonda remains afraid of it. ${ }^{59}$ When she subsequently believes (mistakenly) that Melville has been poisoned, she dies swiftly of a broken heart, betrayed again by her excessive sensibility. A similar heroine appears in Baillie's Orra (1812), a tragedy that Baillie described as being on the 'passion of Fear'. ${ }^{60}$ The play utilises all of the apparatus of gothic horror. Orra, terrified of supernatural visitations, is isolated in a secluded castle rumoured to be haunted, while the conniving Rudigere attempts to prey upon her virtue. The ghost that appears is again not genuine, but it nevertheless drives Orra into madness. ${ }^{61}$

There might be something picturesque about the ghosts of this literature, but they also had a sinister side. The ghosts of the sixteenth and seventeenth centuries were frightening because they were manifestations of the Devil, come to seduce mankind. Gothic ghosts, on the other hand, played on the terrors of insanity, with the mind itself becoming the site of supernatural intrusion. The tension between these two

57 Tobias Smollett, The Adventures of Ferdinand Count Fathom, 2 vols. (London, 1753), i, 113.

58 A. McDonald, Vimonda: A Tragedy (Dublin, 1788), act i, scene i, 5.

59 Ibid., act v, scene ii, 55.

60 Joanna Baillie, 'To the Reader', A Series of Plays, in Which It Is Attempted to Delineate the Stronger Passions of the Mind, 3 vols. (London, 1812), iii, pp. iii-v.

61 See Julie A. Carlson, 'Baillie's Orra: Shrinking in Fear', in Thomas C. Crochunis (ed.), Joanna Baillie, Romantic Dramatist: Critical Essays (London, 2004). 
approaches - an external horror in the form of the Devil, and an internal psychologised horror - is most clearly exhibited in James Hogg's The Private Memoirs and Confessions of a Justified Sinner (1824). The protagonist Robert is haunted by the enigmatic Gil-Martin, who encourages him in a fanatical antinomianism. Robert descends along a path of crime, culminating in his suicide. Gil-Martin is an ambiguous character, and has attracted extensive scholarly attention. ${ }^{62} \mathrm{He}$ can be interpreted as a genuine manifestation of the Devil, but Hogg also allowed for the possibility of a psychological reading, which recasts Gil-Martin as a figment of Robert's imagination. Gil-Martin is not a ghost, but he does demonstrate the terrifying potential of apparitions in the late eighteenth and early nineteenth centuries. Enlightenment discourses urged that ghosts were all in the mind, and therefore need not be an object of fear. Gothic works and their forerunners acknowledged that ghosts might be all in the mind - and went on to show just how frightening that was.

There was another way in which gothic ghosts could be used to evoke fear: through their depiction of death. While once they had returned to discuss the joys of the afterlife, ghosts became reminders of the woes of death. Work on England has identified a re-orientation in priorities 'from the expectation of the world to come to the parting from this one' during the Enlightenment. Death did not become fully secularised, but there was nonetheless a movement in that direction. ${ }^{63}$ Furthermore, the mid-century mournful style of piety reflected a growing cultural emphasis on melancholy. Again considering the French case, McManners writes: 'The eighteenth century had invented a new pleasure - or rather, had brought the secrets of the

62 The scholarship on this topic is extensive, but useful recent discussions include Ian Duncan, 'Fanaticism and Enlightenment in Confessions of a Justified Sinner', in Sharon Alker and Holly Faith Nelson (eds.), James Hogg and the Literary Marketplace: Scottish Romanticism and the Working-Class Author (Farnham, 2009); Penny Fielding, 'The Private Memoirs and Confessions of a Justified Sinner: Approaches', in Ian Duncan and Douglas S. Mack (eds.), The Edinburgh Companion to James Hogg (Edinburgh, 2012); Michelle Faubert, 'John Ferriar's Psychology, James Hogg's Justified Sinner, and the Gay Science of Horror Writing', in Thomas H. Schmid and Michelle Faubert (eds.), Romanticism and Pleasure (Basingstoke, 2010).

63 Julie Rugg, 'From Reason to Regulation: 1760-1850', in Peter C. Jupp and Clare Gittings (eds.), Death in England: An Illustrated History (Manchester, 1999), 202-4, 227; Roy Porter, 'Death and the Doctors in Georgian England', in Ralph Houlbrooke (ed.), Death, Ritual, and Bereavement (London, 1989), 85. See also Houston, who cautions against accepting the secularisation narrative without qualification. R. A. Houston, Punishing the Dead?: Suicide, Lordship, and Community in Britain, 1500-1830 (Oxford, 2010), ch. 6. 
subconscious up to the conscious mind for aesthetic analysis. Sorrow was found to have a hypnotic attraction, and there were sophisticated delights to be discovered in melancholy'. ${ }^{64}$ This pattern was also seen in Britain. The graveyard school included Thomas Warton's tellingly titled 'The Pleasures of Melancholy' (1747), and later gothic literature exuded an atmosphere of gloom. ${ }^{65}$ Poetic ghosts united these trends, painting death in sorrowful hues. A poem from the 1780s began:

Twas at the solemn midnight hour,

That hour when ghosts return,

O'er the dark grave the joys of life

For ever lost to mourn. ${ }^{66}$

Earlier ghosts, who most commonly returned in normal clothing and looked and talked as they had when alive, suggested that death was a mere translation to the afterlife. Romanticised ghosts presented death as a more profound transformation. Blair mourned that it must be 'an awful Thing to die.${ }^{67} \mathrm{He}$ also underlined the universality of death. However much they might avoid lonely church-yards, all men had to join the legions of ghosts eventually:

the task be mine

To paint the gloomy horrors of the Tomb;

Th' appointed place of rendezvous, where all

These trav'llers meet. ${ }^{68}$

Baillie similarly explored this theme. Her 1812 play The Dream endeavoured to rehabilitate the fear of death as a natural human impulse, although she acknowledged that it was against 'the received rules of dramatic dignity, and common-place heroism' ${ }^{69}$

64 McManners, Death and the Enlightenment, 334.

65 David B. Morris describes the arrival, around the mid-century, of a 'new death-centered literature for which the prevailing mood is melancholy'. David B. Morris, 'A Poetry of Absence', in John Sitter (ed.), The Cambridge Companion to Eighteenth-Century Poetry (Cambridge, 2001), 234. See also Rugg, 'From Reason to Regulation', 211; Kenneth Simpson, The Protean Scot: The Crisis of Identity in Eighteenth Century Scottish Literature (Aberdeen, 1988), ch. 2.

66 'Poetry', Aberdeen Magazine, Literary Chronicle, and Review, 31 Dec. 1789, 853-4.

67 Blair, The Grave, 1. 401, p. 22.

68 Ibid., 11. 4-7, p. 3.

69 Baillie, 'To the Reader', v-vi, viii. 
Philippe Ariès has argued that death became more distant over the seventeenth and eighteenth centuries. Among theologians there was an attempt to 'soften [death's] intensity'. ${ }^{70}$ Cemeteries were removed to the outskirts of cities and there was less cultural focus on corpses and skeletons: 'it was the dark, disembodied shadow or the shrouded ghost, rather than the skeleton, that inspired fear after the seventeenth century'. He also notes a growing sense of nothingness; people took less solace in the hope of the beyond. ${ }^{71}$ Nevertheless, the Enlightenment also saw the renewed threat of an untamed, 'savage' death. There was a surge of interest in melancholy and a fresh focus on the dead body, macabre eroticism, and violence in the natural world. Thereafter, the romantic movement of the nineteenth century emphasised the notion of the beautiful death. ${ }^{72}$ Ariès's work is remarkable for its sweeping scope, and therefore generalised; it is unfair to expect his picture to apply on the micro as well as the macro level of history. Handley points out that Ariès's argument about the distancing of death is undermined by the 'dramatic physical representations of death' furnished by ghost stories. ${ }^{73}$ However, it is certainly fair to argue that there was a shift away from the cultural prominence of revenants and the danse macabre, culminating in gothic ghosts. Although these ghosts might bear wounds and wear shrouds, they also tended to be ethereal. They emphasised the profound transformation that occurred with death, but their concept of death was mediated through romantic and fantastical imagery. It is possible to fit this into Ariès's framework. Poetic ghosts did reflect a certain softening and distancing as compared to skeletons and walking corpses. They also had a certain sinister allure to them, foreshadowing the eroticism that (according to Ariès) became tied into notions of death later in the century, as well as the notions of the 'beautiful death' that would follow in the nineteenth. ${ }^{74}$

70 Philippe Ariès, The Hour of Our Death, trans. Helen Weaver (Oxford, 1981), 314-15, 307.

71 Ibid., 328, 322, 342.

72 Ibid., 341, 353, ch. 10.

73 Sasha Handley, Visions of an Unseen World: Ghost Beliefs and Ghost Stories in EighteenthCentury England (London, 2007), 15.

74 Ariès, Hour of Our Death, ch. 10. On the eroticisation of death in gothic literature see Jolene Zigarovich (ed.), Sex and Death in Eighteenth-Century Literature (Abingdon, 2013). Hamish Mathison's essay in this volume, "'Out of Tune": Sex, Death and Gothic Disharmony in Eighteenth-Century Scotland', discusses the Scottish case. On Ariès, death and gothic more generally see Castle, Female Thermometer, ch. 8. 
There are limits to how far this framework can be applied, however. Ariès links the softening of death to a growing mood of calm acceptance (although contrasts it with his notion of the resurgence of 'savage death'). ${ }^{75}$ This theme has been picked up by other historians. Looking at the English picture, Julie Rugg argues that as medical knowledge expanded and fear of eternal damnation receded, death lost much of its terror. ${ }^{76}$ Roy Porter suggests that death 'ceased ... to be the ultimate enemy' and became instead a 'gentle friend', while Guenter B. Risse makes a similar argument with reference to the development of medicine during the Scottish Enlightenment. ${ }^{77}$ This argument is less convincing in the light of the ghosts of gothic poetry. While they may represent death in a milder light than revenants or skeletons, they nonetheless emphasised the aspects of horror and estrangement. As we have seen, gothic ghosts restored an element of terror to the Enlightenment's psychological interpretation of apparitions. Perhaps they can similarly be read as a reaction to the greater medicalisation of death. Physicians stripped death down to a 'natural bodily event', nullifying its element of supernatural horror. ${ }^{78}$ Gothic ghosts remystified death, playing on the melancholic motif that was fashionable both in religious works and literary productions more broadly. They mark a shift away from the medieval fascination with the physical processes of death and decomposition, as well as a departure from that emphasis on the afterlife that we have seen in ghost stories from the late seventeenth and early eighteenth centuries. They were used instead to depict a death that was tragic, frightening and picturesque in equal measure.

\section{Ghosts in Vernacular Poetry}

The remainder of this chapter will focus chiefly on how ghosts became entangled with national identity. This was primarily an eighteenth- and nineteenth-century development, but it built on established ideas. Scotland had long had the reputation

75 Ariès, Hour of Our Death, 307-15.

76 Rugg, 'From Reason to Regulation', 203.

77 Porter, 'Death and the Doctors', 85; Guenter B. Risse, New Medical Challenges During the Scottish Enlightenment (Amsterdam, 2005), 44.

78 Risse, New Medical Challenges, 44. 
of being a land of myth and magic. Hector Boece's 1527 Scotorum Historiae included lengthy descriptions of the country's wondrous features. They included 'barnacle geese' - birds which grew on trees, or hatched from within fir cones. Boece also mentioned fish without fins, floating islands, waves without wind, and a species of fierce white oxen who could not be tamed. These legends reappeared frequently in works about Scotland over the early modern period, reinforcing this reputation abroad..$^{79}$ In England, a perception emerged of Scotland (particularly the Highlands) as being overrun with superstitious beliefs. ${ }^{80}$ When the Duke of Lauderdale sent supernatural stories to Richard Baxter in 1659, he requested that Baxter did not print them, as they would 'make the disaffected jeer Scotland, which is the object of Scorn enough already'. ${ }^{81}$ In the eighteenth and early nineteenth centuries there was a shift towards celebrating this magical reputation, and intertwining it with romantic conceptions of the nation.

There were two primary ways in which romantic authors employed ghosts to reflect on national identity. Firstly, ghosts became representatives of a lively folk tradition. Instead of seeking to stamp out superstitious beliefs, romantic writers marketed them as a sign of Scottish cultural vibrancy. Secondly, ghosts were used as vehicles for social commentary. Ghosts were a symbol not just of the end of life, but also of the end of eras; their predilection to haunt old ruins reflected a desire to cling to times gone by. By their nature, they forced the past upon the present. They thus became a useful tool through which to evaluate social development. Allan Ramsay (16861758), Robert Fergusson (1750-74) and Robert Burns (1759-96) emerged at the forefront of a poetic movement that embraced these trends, in part as a response to English incursion. ${ }^{82}$ The development of the printing press and the 1603 Union of

79 Martin Rackwitz, Travels to Terra Incognita: The Scottish Highlands and Hebrides in Early Modern Travellers' Accounts, c.1600 to 1800 (Münster, 2007), 61-71.

80 Michael Hunter, 'Introduction', in Michael Hunter (ed.), The Occult Laboratory: Magic, Science, and Second Sight in Late Seventeenth-Century Scotland (Woodbridge, 2001), 1-4; Michael F. Graham, The Blasphemies of Thomas Aikenhead: Boundaries of Belief on the Eve of the Enlightenment (Edinburgh, 2008), 139; Lizanne Henderson and Edward J. Cowan, Scottish Fairy Belief: A History (East Linton, 2001), 27.

81 Richard Baxter, The Certainty of the World of Spirits, and Consequently, of the Immortality of Souls of the Malice and Misery of the Devils and the Damned (London, 1691), 85-7.

82 See Rhona Brown, 'Allan Ramsay, Robert Fergusson and Robert Burns', in David Sergeant and Fiona J. Stafford (eds.), Burns and Other Poets (Edinburgh, 2012); Mathison, 'Gothic Poetry in Scotland'; Douglas Gifford, "Nathaniel Gow's Toddy": The Supernatural in Lowland Scottish 
Crowns had allowed for more cultural interaction between England and Scotland. The flip-side was a growing perception that English language and culture were threatening to erode Scots and Scottish traditions. The 1707 Union only heightened these concerns. It became fashionable to spurn 'rustic' Scottish tastes and turns of phrase in favour of English equivalents, and collections of 'Scotticisms' were printed, advising Scots on words or phrases to avoid in refined company. ${ }^{83}$ David Hume is often credited with producing the first list of this sort, as an accompaniment to his 1752 Political Discourses. Among other things, Hume cautioned readers to eschew the phrase 'butter and bread' in favour of 'bread and butter', replace 'simply impossible' with 'absolutely impossible', and say 'get an appetite' rather than 'get a stomach' ${ }^{84}$ Ramsay, Fergusson and Burns contested this cultural imperialism through vernacular explorations of Scottish tradition.

Allan Ramsay used ghosts to add colour to his depictions of the common folk of Scotland. However, his approach tended to be satirical; he associated ghost belief with ignorance and vulgarity. In The Gentle Shepherd (1725), two country women devise a plot to scare a foolish hind (or farm-servant). One woman plays the part of a witch and 'raises' the other, who is dressed 'like a dead Corse in Sheet as white as Milk' ${ }^{85}$ The hind is terrified, and gibbers to his master, who listens with contempt, declaring:

What silly Notions crowd the clouded Mind,

Literature from Burns and Scott to the Present Day', in Lizanne Henderson (ed.), Fantastical Imaginations: The Supernatural in Scottish History and Culture (Edinburgh, 2009).

83 See, for example, M. A. Bald, 'The Anglicisation of Scottish Printing', Scottish Historical Review, xxiii (1926), 107-15; M. A. Bald, 'The Pioneers of Anglicised Speech in Scotland', Scottish Historical Review, xxiv (1927), 179-93; Christine Robinson and Roibeard Ó Maolalaigh, 'The Several Tongues of a Single Kingdom: The Languages of Scotland 1314-1707', in Ian Brown et al. (eds.), The Edinburgh History of Scottish Literature, Vol. 1: From Columba to the Union (Edinburgh, 2007), 162-3; Charles Jones, 'Nationality and Standardisation in EighteenthCentury Scotland', in Raymond Hickey (ed.), Eighteenth-Century English: Ideology and Change (Cambridge, 2010); Joan Beal, 'Syntax and Morphology', in Charles Jones (ed.), The Edinburgh History of the Scots Language (Edinburgh, 1997), 336-8; Richard Bailey, 'Scots and Scotticisms: Language and Ideology', Studies in Scottish Literature, xxvi (1991), 65-77.

84 David Hume, 'Scotticisms', The Philosophical Works of David Hume, 4 vols. (Edinburgh, 1826), i, cxxvii, cxxix.

85 Allan Ramsay, The Gentle Shepherd: A Scots Pastoral Comedy (Edinburgh, 1725), act v, scene i, 73. 
That is throw want of Education blind.$^{86}$

In his 'Elegy on John Cowper, Kirk-Treasurer's Man, Anno 1714' (first published 1718), Ramsay similarly described a returning ghost with the dry caution that his readers should

tak good Tent ye dinna file

Ye'r Breeks for Fear. ${ }^{87}$

On one hand Ramsay began a literary trend, later continued by Smollett, of casting the supernatural in a humorous and farcical light, with emphasis on popular credulity. However, Ramsay also used ghosts as political messengers. 'A Tale of Three Bonnets' (1722) tells of Duniwhistle, an old man on his deathbed, who calls his three sons to him and presents them each with a bonnet. These bonnets signify virtue, and the men are warned not to remove them. However, one son is seduced by Rosie, a beautiful heiress representing England. She attempts to destroy two of the bonnets. Duniwhistle returns as 'a stalwart Ghaist', with 'stern and angry Looks', and saves the bonnets. He upbraids the son who was seduced by Rosie's charms, but offers some hope for the future:

Be a' thy days an Ass,

And Hackney to this cunning Lass;

But for these BONNETS, I'll preserve them,

For Bairns unborn, that will deserve them. ${ }^{88}$

Similarly, Ramsay's 'The Vision' (1724), published under the name A. R. Scott and allegedly written around the year 1300, presents a figure from the past appearing in a dream and critiquing the Wars of Independence. As Douglas Gifford points out, the analysis might just as well be applied to the recent Jacobite engagements. ${ }^{89}$ The apparition argues that trade is coming to a standstill and 'cunzie' (coin) is forsaking

86 Ibid., 74.

87 Allan Ramsay, Elegies on Maggy Johnston, John Cowper, and Lucky Wood, 2nd edn (Edinburgh, 1718), 14.

88 Allan Ramsay, A Tale of Three Bonnets ([Edinburgh?], 1722), canto iv, 27. See Mathison, 'Gothic Poetry in Scotland', 36-8.

89 Gifford, 'Nathaniel Gow's Toddy', 115-16. 
the land, and explains that Scotland will be renewed

Quhen Scottish Peirs slicht Saxon gold,

And turn trew heartit men;

Quhen Knaivry and Slaivrie,

Ar equally dispysd. ${ }^{90}$

These ghosts personified an idealised past Scotland, reproaching contemporary Scots for their submission to England. Ghosts were used similarly in other works after Ramsay's. A 1729 pamphlet by 'C. N.' described the ghostly return of John Hamilton, second Lord Belhaven, who died in 1708. Belhaven gave a speech against the Union in the year of his death. In the pamphlet he appears to reproach the 'sons of Caledon', and rants about the 'hottest Vengeance' and 'smoaking Sulphur' that awaits those who have

Sold

Themselves to slavery, for betraying Gold: ${ }^{91}$

These themes re-emerged in Robert Fergusson's 'The Ghaists: A Kirk-Yard Eclogue' (1773). This poem describes a conversation between the ghosts of two Edinburgh men, George Heriot and George Watson, who meet in a graveyard to enjoy their 'nightly freedom' before the cock-crow sends them back to their tombs. They discuss the controversial Mortmain Bill, which was to compel Scottish trusts to buy English government stock, and mourn the Union, foretelling Scotland's downfall:

Ah, Caledon! the land I yence held dear,

Sair mane mak I for thy destruction near;

They are themselves powerless to alter Scotland's course, but debate the possibility of engaging some ghost 'that trokes and conjures wi' Auld Nick' to cause meteorological chaos, 'Till Scotland's out o' reach o' England's pow'r'. ${ }^{92}$ The

90 Allan Ramsay, 'The Vision', in Allan Ramsay (ed.), The Ever Green, Being a Collection of Scots Poems, 2 vols. (Edinburgh, 1724), i, v. xiii, 220.

91 C. N., A Counsel of Criminal Ghosts to the Ghost of the Great Beilhaven (Edinburgh, 1729), 3, 4.

92 Robert Fergusson, 'The Ghaists: A Kirk-Yard Eclogue', Weekly Magazine, or Edinburgh Amusement, 27 May 1773, 275-6. See Mathison, 'Gothic Poetry in Scotland', 41-2. 
implication is that truly patriotic Scots should stop at nothing to reclaim their national independence.

Robert Burns also offered critiques of Anglo-Scottish relations, most notably in 'Such a Parcel of Rogues in a Nation' (1791). However, he is better remembered for his depictions of the liveliness of Scottish folk belief. In 'Halloween' (1785) he annotated his Scots description of superstitious traditions with English explanations, underlining the indigenous nature of the folk culture he was exploring. Thereafter, 'Tam o' Shanter' (1790; first published 1791) presents a vision of this culture that is full of colour and vitality. The poem delves into traditions of the witches' Sabbat with a mixture of bawdiness and genuine horror, and - as Ian Duncan argues - marks a new style of vernacular story-telling based on folk tradition. ${ }^{93}$ Neither of these poems included ghosts as such, but they celebrated a world of popular belief in which ghosts had a natural place. Burns also made use of ghostlike spirits to reflect on the changing nature of Scottish society, again with reference to English incursion. The power of the old Scottish aristocracy declined in the eighteenth century as the professional classes expanded. David Punter argues that a central theme of Scottish gothic was the replacement of a traditional, violent authority by 'the middling (and meddling) rule of law', which was perceived as destroying a national way of life. ${ }^{94}$ Punter is writing about the work of Walter Scott, but his argument might also be applied to Burns's 'The Brigs of Ayr' (1787). This poem presents an argument between the spirits of two bridges. The Auld Brig symbolises a bygone generation:

Auld Brig appear'd of ancient Pictish race, The vera wrinkles gothic in his face:

The New Brig, on the other hand, represents a modern Scotland, clad in English finery:

New Brig was buskit in a braw, new coat, That he, at Lon'on, frae ane Adams got; ${ }^{95}$

93 Duncan, 'Walter Scott, James Hogg and Scottish Gothic', 126.

94 Punter, 'Scottish and Irish Gothic', 110, 111-12.

95 Robert Burns, 'The Brigs of Ayr', Poems, Chiefly in the Scottish Dialect (Edinburgh, 1787), 71. 
The New Brig mocks the Auld Brig as a 'ugly gothic hulk', and insults the 'gaunt, ghastly, ghaist-alluring edifices' of its architecture. The Auld Brig retorts: 'Conceited gowk! puff'd up wi' windy pride'. ${ }^{96}$ It proceeds to criticise the 'staumrel, corkyheaded, graceless Gentry' who had come to rule (and ruin) the country, and describes how the great folk of the past will

curse the time and place

When ye begat the base, degen'rate race! ${ }^{97}$

Burns's approach is more even-handed than those of Ramsay and Fergusson. Both bridges are allowed their say, and their argument is ultimately overshadowed by the appearance of spirits of nature, benevolence, courage, learning and peace. Burns thus presents a way to move forward and reconcile the conflicting forces within Scottish society. Nevertheless, 'The Brigs of Ayr' continues along the path laid out by Ramsay and Fergusson, using ghostlike beings to explore the discord between Scotland's independent past and North British present.

\section{Ossian and the Romanticisation of the Highlands}

More obviously romanticised depictions of Scottish supernatural traditions also appeared, linked in particular to the Highlands. Perceptions of the Highlands changed significantly over the course of the eighteenth century. The region had traditionally been presented as a dangerous place, peopled by barbarians. In 1535, Peder Svave wrote that 'the wild Scots live in the manner of the Scythians, they are ignorant of the use of bread; when they are hungry they outstrip a stag in swiftness of foot, overtake it and kill it, and so sustain life: they eat the flesh raw, only squeezing out the blood'. The English antiquarian William Camden's 1586 Britannia described the Highlanders as wild, warlike, cruel, hateful, and inclined to robbery and theft. ${ }^{98}$ This

See Mathison, 'Gothic Poetry in Scotland', 35, 42-3.

96 Burns, 'The Brigs of Ayr', 73, 76, 74.

97 Ibid., 79, 78.

98 Svave is quoted and Camden discussed in Rackwitz, Travels to Terra Incognita, 94, 52-4. 
stereotype was reinforced in eighteenth-century England by the Jacobite uprisings. However, after the 1745 uprising had been quelled, and the Highlanders ceased to pose a genuine threat to British stability, their warlike qualities came to be perceived in a more positive light. A character of Smollett's explained:

They greatly excel the Lowlanders in all the exercises that require agility; they are incredibly abstemious, and patient of hunger and fatigue; so steeled against the weather, that in travelling, even when the ground is covered with snow, they never look for a house, or any other shelter but their plaid, in which they wrap themselves up, and go to sleep under the cope of heaven. Such people, in quality of soldiers, must be invincible, ${ }^{99}$

From the start of the Seven Years' War in 1756 to the end of the Napoleonic Wars, more than 48,300 men were recruited from the Highlands and Islands to serve in regiments of the British army. ${ }^{100}$ In 1766, William Pitt defended the recruitment of the 'hardy and intrepid race of men' from 'the mountains of the north'. The Highland soldier-hero became a recognised trope, enhanced by the emerging Enlightenment conception of the 'noble savage'. ${ }^{101}$

Furthermore, as roads were improved, tourism to the Highlands expanded. The $1780 \mathrm{~s}$ and $1790 \mathrm{~s}$ in particular saw burgeoning numbers of visitors, partly inspired by Samuel Johnson's 1775 tour of the western isles. ${ }^{102}$ There was a growing aesthetic appreciation for the region. Edmund Burt, visiting in the 1720s, was unimpressed by the landscape. It was all 'horrid Gloom', 'a dismal gloomy Brown, drawing upon a dirty Purple'; the mountains were 'monstrous Excrescencies'. The scenery, he asserted, was 'most of all disagreeable, when the Heath is in Bloom'. ${ }^{103}$ Daniel Defoe, visiting Drumlanrig in mid-1720s, called the mountains 'hideous' ${ }^{104}$ This was

99 Tobias Smollett, The Expedition of Humphry Clinker, 2 vols. (Dublin, 1771), ii, 105.

100 Robert Clyde, From Rebel to Hero: The Image of the Highlander, 1745-1830 (East Linton, 1995), 150.

101 Kenneth McNeil, Scotland, Britain, Empire: Writing the Highlands, 1760-1860 (Columbus, 2007), 86, 27. See also Peter Womack, Improvement and Romance: Constructing the Myth of the Highlands (Basingstoke, 1988), ch. 2; Clyde, From Rebel to Hero, ch. 6.

102 Rackwitz, Travels to Terra Incognita, 146-248, esp. 192.

103 Edmund Burt, Letters from a Gentleman in the North of Scotland, 2 vols. (London, 1754), ii, letter xv, 11, 10, 14.

104 Daniel Defoe, A Tour Through the Whole Island of Great Britain, eds. P. N. Furbank, W. R. Owens, and A. J. Coulson (New Haven, 1991), 323. 
not limited to Englishmen: John Clerk of Penicuik toured northern Scotland in 1739, and wrote: 'From Dalwhinny, about 10 or 12 miles we came to Riven in Badenoch. By the way all along from the Blair to this place I cou'd see nothing but a barbarous tract of mountains on both hands and scarse a stalk of grass to be seen. ${ }^{, 05}$ However, by the later eighteenth century the landscape was commonly thought to be romantic and awe-inspiring. Thomas Pennant, travelling in 1769, declared that 'the pass into the Highlands is awefully magnificent', and described the mountains as a 'scene of horrible grandeur' ${ }^{106}$ Walter Scott is reported to have said that 'if I did not see the heather at least once a-year, I think I should die!'107 This coincided with the development of landscape painting in Scotland, which resulted in the circulation of sublime Highland scenes. ${ }^{108}$

Literary works played an important role in developing these conceptions of the Highlands. One English figure is worth mentioning first of all. William Collins's $A n$ Ode on the Popular Superstitions of the Highlands of Scotland (written in 1749-50, and first published in 1788) was an important forerunner in romantic depictions of the Highlands - or 'Fancy's land', to use Collins's terminology. The ghosts Collins presents are theatrical, poignant figures. The 'mournful sprite' of a drowned sailor returns to his wife while she sleeps, 'shiv'ring cold' and speaking in 'piteous accents'. He beseeches her to pursue her 'daily toils' as before, and think of him no more. Collins also describes how second sighted people see 'the gliding ghosts unbodied [trooping]' over the 'wat'ry strath or quaggy moss'. ${ }^{109}$ Peter Womack points out that Collins drew his material from Martin Martin's account of Highland folklore, but dramatised it. Second sight apparitions were converted into ghosts: 'He has made the seers see ghosts and ... powerful superhuman spirits, rather than images of ordinary living people', thus creating a 'Hebrides of melancholy and fear strikingly

105 Quoted in Rackwitz, Travels to Terra Incognita, 235.

106 Thomas Pennant, A Tour in Scotland 1769 (Chester, 1771), 74, 98.

107 From an 1817 letter by Washington Irving, given in John Gibson Lockhart, Memoirs of the Life of Sir Walter Scott, 2nd edn, 10 vols. (Edinburgh, 1839), v, 249.

108 James L. Caw, Scottish Painting Past and Present, 1620-1908 (Edinburgh, 1908), 136-62, esp. 138; Charles W. J. Withers, Geography, Science and National Identity: Scotland Since 1520 (Cambridge, 2001), 153.

109 William Collins, An Ode on the Popular Superstitions of the Highlands of Scotland (London, 1788), v. ii, 10; v. viii, 17-18; v. iv, 12. 
unlike Martin's' ${ }^{110}$ Collins's approach to the Highlands was unusual at the time he was writing, but just a few decades later (when the poem was published) his romanticised vision was in keeping with the popular view of the region.

This was largely because of the influence of the best known romantic work of eighteenth-century Scotland, James Macpherson's Ossian poetry. Macpherson (1736-96) composed and compiled this cycle of epic poetry with reference to Irish mythology and Scottish Gaelic ballads. ${ }^{111}$ He claimed that the poems were the work of the ancient bard Ossian, translated from the Gaelic, and that they represented the rediscovery of a forgotten Celtic past. Publication began in 1760; a collected edition followed in 1765; and the world of Ossian became famous throughout Europe. ${ }^{112}$ This world is an ethereal place, on the brink of dissolution. Ossian is a narrator in his old age, blind, and the last survivor of his race. Ghosts blend easily into this atmosphere, and are featured frequently within the poetry. These ghosts follow classical Greek and Roman models, and are not terrifying or uncanny in the gothic fashion. ${ }^{113}$ They are usually the ghosts of past heroes, a natural part of their world and venerated by their descendants. They come clad in armour and bearing the wounds of battle. Nevertheless, they tend to be incorporeal. One is seen with 'the stars dim[twinkling] through his form'. Another explains: 'My ghost, O Connal, is on my native hills; but my corse is on the sands of Ullin'. ${ }^{114}$ They are also poignant figures: pale and enfeebled, sorrowful, with weak voices and 'airy limbs' ${ }^{115}$ Their wounds and their armour serve rather to accentuate their heroic, tragic elements than to tie

110 Womack, Improvement and Romance, 91-2.

111 See Derick S. Thomson, The Gaelic Sources of Macpherson's Ossian (Edinburgh, 1952); Donald E. Meek, 'The Gaelic Ballads of Scotland: Creativity and Adaptation', in Howard Gaskill (ed.), Ossian Revisited (Edinburgh, 1991).

112 Duncan, 'Walter Scott, James Hogg and Scottish Gothic', 72.

113 On classical influences see Hugh Blair, A Critical Dissertation on the Poems of Ossian (London, 1763), 33-8; Jeremy M. Downes, Recursive Desire: Rereading Epic Tradition (Tuscaloosa, 2014), 140-1; Josef Bysveen, Epic Tradition and Innovation in James MacPherson's Fingal (Uppsala, 1982), 120-5; Fiona J. Stafford, The Sublime Savage: James McPherson and the Poems of Ossian (Edinburgh, 1988), 138-9. For a slightly different viewpoint see Fiona J. Stafford, "'Dangerous Success": Ossian, Wordsworth, and English Romantic Literature', in Howard Gaskill (ed.), Ossian Revisited (Edinburgh, 1991), 63, which emphasises the frightening aspects of the Ossianic ghosts.

114 James Macpherson, 'Fingal, an Ancient Epic Poem', The Works of Ossian, the Son of Fingal, 2 vols. (London, 1765), i, bk. ii, 33.

115 Ibid., bk. ii, 34, bk. iv, 74; James Macpherson, 'The War of Caros: A Poem', The Works of Ossian, the Son of Fingal, 2 vols. (London, 1765), i, 144. 
them to their earthly selves. The chief of Erin, seeing an insubstantial ghost with a weak arm, cries: 'How art though changed, chief of Lara! ... Thou art not Calmar's ghost ... his arm was like the thunder of heaven.' 116

Macpherson's ghosts are sometimes purely atmospheric figures; they 'fly on clouds and ride on winds'. ${ }^{117}$ However, ghosts are also allowed an active role. They fight, foretell the future and spur the living on to action. Fingal battles the spirit of Loda; his sword 'winds through the gloomy ghost', and 'the form [falls] shapeless into the air, like a column of smoke'. ${ }^{118}$ In another work of Macpherson's a ghost returns to press his son into avenging his death:

Before my eyes a ghastly vision stood;

A mangled man, his bosom stain'd with blood!

He hands my sword, emits a feeble groan,

And weakly says, 'revenge me, O my son!' 119

In a sense, this echoes the role of late seventeenth- and early eighteenth-century ghosts, who might similarly return to ensure that their murderers were brought to justice. Macpherson's ghosts did not operate within a religious framework, however, and could not be read as a tool of God's providential justice. Josef Bysveen argues that they appear 'only in episodes where they are closely associated with the theme of love'. ${ }^{120}$ Bonds of affection draw ghosts back to their kin, sentimentalising the scenes while also underlining the importance of clan networks within Highland society. Given their great popularity, the poems of Ossian probably contributed more than any other Scottish work to the development of the notion of the ghost as a romantic literary device, divorced from religious significance.

As with the ghosts of Ramsay, Fergusson and Burns, Macpherson's ghosts can be

116 James Macpherson, 'The Death of Cuchullin: A Poem', The Works of Ossian, the Son of Fingal, 2 vols. (London, 1765), i, 211-12.

117 Macpherson, 'Fingal', bk. ii, 35.

118 James Macpherson, 'Carric-Thura, a Poem', The Works of Ossian, the Son of Fingal, 2 vols. (London, 1765), i, 279.

119 James Macpherson, The Highlander: A Poem (Edinburgh, 1758), canto v, 64-5.

120 Bysveen, Epic Tradition, 128. 
read politically, in this case as a response to the Jacobite failures. Macpherson was himself a Highlander, and his clan was involved in the 1745 uprising. ${ }^{121}$ After the failure of the uprising the government passed measures designed to subdue the Highlanders. Road-building and mapping projects made the area more accessible, government garrisons were built, and more English-speaking schools were founded. The power of clan chiefs was limited, and traditional dress was banned. ${ }^{122}$ The poems of Ossian hearken back to a romantic Celtic past (albeit a largely fabricated one), reinforcing Gaelic identity in the face of governmental suppression. Macpherson gave his work a patriotic message from the outset by dedicating it to John Stuart, Earl of Bute, the first Scottish prime minister. Stuart was regarded by some as a Highlander, despite having been born in Edinburgh and educated in England. ${ }^{123}$ Furthermore, within Ossian's world there is a pervading sense that something beautiful has been left behind. Ossian is haunted by the past, by the memories of his dead kinsfolk. ${ }^{124}$ The theme of degeneration reappears frequently, exemplified in the ghost who has eyes 'like two decaying flames'. Ghosts take an interest in the present; they are said to rest in caves together and talk of mortal men. ${ }^{125}$ However, they stand above and apart from humans, the closest thing to the sublime that can be found in Ossian's world. ${ }^{126}$ They represent a greater wisdom, the authority of age and of a venerable past, which is nonetheless powerless to alter the sorry path of the future. The Ossian poetry draws on the melancholic themes we have seen in poetry such as Blair's, and diverts them into a mourning for the loss of a greater Scotland.

121 See Derick S. Thomson, 'Macpherson, James (1736-1796)', Oxford DNB (Oxford University Press, 2004), http:/www.oxforddnb.com/view/article/17728, accessed 1 Aug. 2015; Stafford, Sublime Savage; Murray G. H. Pittock, The Invention of Scotland: The Stuart Myth and the Scottish Identity, 1638 to the Present (London, 1991), 73-9.

122 Withers, Geography, Science and National Identity, 150; Bruce Lenman, The Jacobite Risings in Britain, 1689-1746 (Dalkeith, 1980), 277-9; T. M. Devine, Clanship to Crofter's War: The Social Transformation of the Scottish Highlands (Manchester, 1994), 29, 113-14; Geoffrey Plank, Rebellion and Savagery: The Jacobite Rising of 1745 and the British Empire (Philadelphia, 2005), 106-7.

123 J. A. Lovat-Fraser, John Stuart, Earl of Bute (Cambridge, 1912), 3; see Leith Davis, Acts of Union: Scotland and the Literary Negotiation of the British Nation, 1707-1830 (Stanford, 1998), 75-81.

124 Duncan, 'Walter Scott, James Hogg and Scottish Gothic', 125.

125 Macpherson, 'Fingal', bk. ii, 32, 35.

126 See Bysveen, Epic Tradition, ch. 6; JoEllen M. DeLucia, “Tales of Other Times": Scotland's Past and Women's Future in Eighteenth-Century British Writing' (Indiana University PhD thesis, 2007), 75; Stafford, Sublime Savage, 156. 
The Ossianic ghosts were majestic but chimerical, like the vision of Scottish history underlying the poetry. In the nineteenth century the revels ended; Macpherson's spirits melted into air. With Scott at their forefront, early nineteenth-century antiquarians moved to distance themselves from Macpherson's fabricated Celtic past - a process Colin Kidd has described as 'national demythologising'. ${ }^{127}$ Nevertheless, there remained a drive to carve out a distinctive Scottish identity. War with France, agricultural and industrial revolutions and a shift towards Whiggism brought Scotland and England closer together in the early nineteenth century, exacerbating fears that Scottish culture would lose its relevance. ${ }^{128}$ John Sinclair, compiler of the first Statistical Account of Scotland (1791-9), explained that the Scots 'have reason to be proud of the name of Britons', but nonetheless 'ought not to relinquish on that account, all remembrance of characteristic dress, language, music, or customs of their ancestors. If in these respects they become totally assimilated to the English, Scotland becomes completely confounded in England.' ${ }^{129}$ While grand national myths were rejected, the romanticisation of folk belief and Highland traditions intensified. The latter was best exemplified by George IV's 1822 visit, masterminded by Sir Walter Scott, which saw Lowlanders - and George himself - donning kilts. In this context, ghosts remained significant: they could play the role of folkloric curiosities just as they could become ancient representatives of a great bygone Scotland. This was seen most clearly in the development of antiquarian studies. Before we move away from the realm of fiction, however, it is worth dipping briefly into the work of Walter Scott (1771-1832) and James Hogg (1770-1835). Hogg and Scott had slightly different approaches to ghosts, but both demonstrate how the project of nation-building had changed by the nineteenth century.

Scott's 'The Tapestried Chamber' (1829) has been described as the 'first modern

127 Colin Kidd, Subverting Scotland's Past: Scottish Whig Historians and the Creation of an AngloBritish Identity, 1689-1830 (Cambridge, 1993), 257.

128 Michael Lynch, Scotland: A New History (London, 1992), 357-9; Womack, Improvement and Romance, 145; T. M. Devine, The Scottish Nation, 1700-2007 (London, 2006), 244-5; Kidd, Subverting Scotland's Past, 273-5.

129 Quoted in McNeil, Scotland, Britain, Empire, 2. 
British ghost story'. ${ }^{130}$ It is an expanded version of a story that appeared in Blackwood's in 1818, attributed to 'A. B.'. A general stays in a room that was once witness to incest and 'unnatural murder'. He is disturbed in the night by a monstrous spectre: 'Upon a face which wore the fixed features of a corpse, were imprinted the traces of the vilest and most hideous passions which had animated her while she lived. The body of some atrocious criminal seemed to have been given up from the grave'. ${ }^{131}$ This ghost is reminiscent of the medieval revenant. By contrast, the wraith of Alice in The Bride of Lammermoor (1819) is an ethereal figure, who leaves the grass untrodden as she passes. ${ }^{132}$ The White Lady in The Monastery (1820) is similarly incorporeal, being able to melt into the air. She appears as a beautiful woman 'with a voice of ineffable sweetness'. Unlike the ghost in 'The Tapestried Chamber' or Alice's wraith, the White Lady is not really a dead person; Scott compares her to a brownie or fairy, and she explains that she is

Something betwixt heaven and hell-

Something that neither stood nor fell- ${ }^{133}$

Semi-transparent and clad in white, however, the figure taps into ghost stereotypes. Scott's work demonstrates that interest in aesthetics that was characteristic of the romantic authors when it came to ghosts, but also hints at the diversity of ghost stereotypes in circulation.

While Scott presented two ends of a scale, Hogg went further, also offering everything in between. The ghost in The Three Perils of Man (1822) is a sorrowful, noble figure who appears as a gliding white-clad lady, resembling a 'flight o' white mist', a 'streamer o' light' or 'the reflection of a starn in the water'. ${ }^{134}$ The ghost in ‘The Mysterious Bride' (1830) looks like a normal young woman, clad in a white

130 Roger Clarke, A Natural History of Ghosts (London, 2012), 308.

131 Walter Scott, 'The Tapestried Chamber', in Frédéric Mansel Reynolds (ed.), The Keepsake for 1829 (London, 1829), 142, 136. The Blackwood's story is A. B., 'Story of an Apparition', Blackwood's Edinburgh Magazine, Sept. 1818, 705-7.

132 Walter Scott, 'The Bride of Lammermoor', Tales of My Landlord, 4 vols. (Edinburgh, 1819), ii, 218-20.

133 Walter Scott, The Monastery: A Romance, 3 vols. (Edinburgh, 1820), i, 316.

134 James Hogg, The Three Perils of Man: Or, War, Women, and Witchcraft, 3 vols. (London, 1822), i, 256-7. 
dress with a green bonnet and veil, and when her enamoured young laird meets her in a dream he finds her to be 'a being of real flesh and blood'. She behaves in a more sinister manner, luring the laird to his death. ${ }^{135}$ Another of Hogg's ghosts is 'dressed in dead-clothes; that is, it was wrapt in a coarse white sheet, and had a napkin of the same colour round its head'. ${ }^{136}$ Hogg also recognised revenant traditions. A supposed ghost has 'the appearance of a warrior sheathed in steel, but all encrusted in a sheet of blood. His mouth was wide open, and his jaws hanging down upon his breast, while his head seemed to be cleft asunder.' ${ }^{137}$ Along similar lines, the ghost in 'Welldean Hall' (1820) returns in his dressing gown, but underneath his 'loins and limbs' are 'sheathed in red hot burning steel, while a corslet of the same glowing metal enclosed his breast and heart'. His face is filled with 'defiance, rage, and torment'. 138

If Scott and Hogg were adventurous when it came to ghosts' appearances, they were more restrained with respect to broader messages. Their work does not pose the same challenge to Anglo-Scottish relations that can be seen in the poetry of Ramsay or Fergusson. Scott was pro-Union. He romanticised the Jacobite rebellions, but only because they were safely confined to the past. His aim was to furnish a distinctive Scottish identity without challenging the concept of Britishness, a unionist nationalist approach that would become more dominant as the nineteenth century progressed. ${ }^{139}$ Like Burns, he took an interest in the supernatural primarily as the product of a distinctively Scottish folk tradition. Before introducing the wraith of Alice in The Bride of Lammermoor, he explained: 'We are bound to tell the tale as we have received it; and, considering the distance of the time, and propensity of those through whose mouths it has passed to the marvellous, this could not be called a Scottish

135 James Hogg, 'The Mysterious Bride’, Blackwood's Edinburgh Magazine, Dec. 1830, 943-50 (quotation 947).

136 James Hogg, 'The Adventures of Basil Lee', in Ian Duncan (ed.), Winter Evening Tales (Edinburgh, 2004), 56.

137 Hogg, Three Perils of Man, 308.

138 James Hogg, 'Welldean Hall', in Ian Duncan (ed.), Winter Evening Tales (Edinburgh, 2004), 453.

139 McNeil, Scotland, Britain, Empire, 51-2; Juliet Shields, Sentimental Literature and AngloScottish Identity, 1745-1820 (Cambridge, 2010), 5-6, ch. 5; Allan I. Macinnes, Union and Empire: The Making of the United Kingdom in 1707 (Cambridge, 2007), 34-5; Graeme Morton, Unionist-Nationalism: Governing Urban Scotland, 1830-1860 (East Linton, 1999). 
story, unless it manifested a tinge of Scottish superstition'. ${ }^{140}$ As James Watt notes, Scott employed similar techniques in The Lay of the Last Minstrel (1805): 'Scott ... clearly distanced The Lay from ... a casual recourse to supernatural agency, by attempting to supervise "the Marvellous in Poetry" and give it ethnographic validation as the property of popular tradition or belief'. ${ }^{141}$

The works of Hogg, meanwhile, lack the 'sense of national grievance' that is usually associated with the romantic national tale (to quote Graham Tulloch), and he was little concerned with contrasting divergent national cultures. ${ }^{142}$ His approach to folklore was generally playful. He flirted with gothic themes, but subverted them, mingling the grotesque with the humorous. 'Welldean Hall' is brimming with gothic elements: a virtuous heroine, torn apart from her beloved and pursued by his lascivious brother; a hidden fortune; a ghost, clad in burning steel, terrorising the manor house he used to possess. However, Hogg's depictions of the locals' interactions with the ghost are sardonic, and contain no traces of genuine horror. There is a great deal of humour in the butler's explanation of his encounter with the ghost, which ended with him in a drunken stupor, such that 'If there had been fifty ghosts, it would have been the same to old Gibby'. ${ }^{143}$

For all his sportiveness, Hogg did not tend to mock his credulous characters. He allowed for subtlety within popular belief systems, having one of his characters explain that

ye had need to tak care how ye dispute the existence of fairies, brownies, and apparitions ... ye may as weel dispute the gospel o' Sant Matthew. We dinna believe in a' the gomral fantastic bogles an' spirits that fley light headed fock up an down the country, but we believe in a' the apparitions that warn o' death, that save life, an' that discover guilt. ${ }^{144}$

140 Scott, 'Bride of Lammermoor', 217.

141 James Watt, Contesting the Gothic: Fiction, Genre and Cultural Conflict, 1764-1832 (Cambridge, 1999), 133.

142 Graham Tulloch, 'Hogg and the Novel', in Ian Duncan (ed.), The Edinburgh Companion to James Hogg (Edinburgh, 2012), 125.

143 Hogg, 'Welldean Hall', 463-4.

144 James Hogg, 'The Wool-Gatherer', The Brownie of Bodsbeck, and Other Tales, 2 vols. (Edinburgh, 1818), ii, 140. 
Furthermore, Hogg did not consistently undermine the reality of his supernatural beings. The Brownie of Bodsbeck and the ghost in 'The Bridal of Polmood' both prove to be living men, and as we have seen, The Private Memoirs and Confessions of a Justified Sinner leaves scope for an alternative, psychological reading. However, Hogg also presented many stories with genuine supernatural creatures, 'Welldean Hall' included. Indeed, in 'The Mysterious Bride', Hogg complained about the tendency to undermine the reality of the supernatural:

A great number of people nowadays are beginning broadly to insinuate that there are no such things as ghosts, or spiritual beings visible to mortal sight. Even Sir Walter Scott is turned renegade, and, with his stories made up of half-and-half, like Nathaniel Gow's toddy, is trying to throw cold water on the most certain, though most impalpable, phenomena of human nature. The bodies are daft. Heaven mend their wits. ${ }^{145}$

Hogg may not have had an overtly nationalist agenda, but his depiction of popular belief was laudatory. Compared to their seventeenth-century predecessors, the approaches of Scott and Hogg were depoliticised, but they bolstered ideas about the distinctiveness and importance of Scotland's folk culture.

\section{Antiquarian Studies}

The drive to identify and record a distinctive Scottish folklore was not limited to fiction. The late seventeenth century saw the rising popularity of antiquarian pursuits, a movement which further developed in the late eighteenth and early nineteenth centuries. It is worth comparing the two phases of this movement, as their similarities and differences are illuminating. We have seen that in the late seventeenth and early eighteenth centuries, men such as Robert Wodrow, George Sinclair and Robert Kirk collected supernatural stories for religious and scientific reasons. Another driving force was blossoming interest in geography. As Charles Withers notes, the last two decades or so of the seventeenth century were 'a crucial period in the making of geographical and scientific knowledge in Scotland'. Geography was increasingly

145 James Hogg, 'Mysterious Bride', 943. 
taught in universities, and Sinclair himself was licensed to teach it publicly in 1670. ${ }^{146}$ In 1682 the physician and antiquary Robert Sibbald was appointed Geographer Royal, and the mathematician John Adair was commissioned to prepare maps and chorography by an act of parliament passed in 1686. New maps were produced, and in 1708 the first public geography class was founded in Edinburgh. ${ }^{147}$ Geographical knowledge was increasingly linked to national pride. In 1728 the schoolmaster and surveyor George Mark decried the inaccuracies in maps of the shires of Lothian, Tweeddale and Clydesdale, exclaiming:

'Tis truly strange why our Scottish Nobility and Gentry, who are so universally esteemed for their learning, Curiousity and Affection for their Country, should suffer an Omission of this Nature! Can they, whom their Neighbours as it were by way of Distinction call National, contentedly see themselves outdone by those Neighbours, in what so much concerns the Honour of their Nation? ${ }^{148}$

Learning about the nation and developing national identity was, therefore, a motivation for folkloric research in the late seventeenth and early eighteenth centuries. It is no coincidence that it was around this time - in the $1690 \mathrm{~s}$ - that Scotland made its most significant attempt to set up an overseas colony with the illfated Darien scheme. There was something imperialist about the exploration of Highland beliefs in particular; as noted above, movements to subdue the Highlands focused partly on exploring and describing the area. Furthermore, supernatural stories were tied to national pride, as they demonstrated God's interest in Scotland. We can recall that a key motivation for Wodrow in compiling Analecta was his desire to show that 'in poor Scotland, the Lord, since the Reformation, hath manifested himself, and the secret of his covenant, to his servants and people, as much as any where since the primitive times'. ${ }^{149}$

146 Withers, Geography, Science and National Identity, 69, 97. Note that Sinclair did not, however, have a university post at this point (as Withers suggests).

147 Ibid., 72-84, 91-6, 119, 103; Christopher Fleet et al., Scotland: Mapping the Nation (Edinburgh, 2011).

148 Quoted in Withers, Geography, Science and National Identity, 149.

149 Robert Wodrow, The Correspondence of the Rev. Robert Wodrow, ed. Thomas M'Crie, 3 vols. (Edinburgh, 1842), ii, 244. 
Nevertheless, religion remained the primary motivator for most of the seventeenth and early-eighteenth century folklorists, and they recorded material selectively according to their theological goals. The exception was Martin Martin, who conducted his investigations in the 1690s and published his Description of the Western Islands of Scotland in 1703. Spurred on by the enquiries of the Royal Society in England, his primary intention was to record information about a littleknown community, rather than to collect a specific subset of stories for theological purposes. ${ }^{150}$ Martin's approach was unusual at the time, but as the eighteenth century progressed it became more common. Ballads and popular songs were an early area of interest. Allan Ramsay's Tea-Table Miscellany (1724-7) was an anthology that brought together 'A Collection of Choice Songs Scots and English'. From the 1760s a large number of ballad collections were printed, and Walter Scott took up the baton The Minstrelsy of the Scottish Border (1802-3). ${ }^{151}$ Thereafter, the first few decades of the nineteenth century saw a shift away from the exclusive focus on the ballad. Increasingly, the 'tale' came to be valued as a subject for antiquarian study. Tim Killick suggests that this was linked to Scott's shift from poetry to the novel. By the 1820 s, it was also influenced by the short fiction popularised by Blackwood's. A strong market for book-length collections of short fiction had emerged by the $1820 \mathrm{~s}$, and supernatural stories were a common feature. ${ }^{152}$ Local legends also began to draw fresh attention. The 1820 s and 1830 s in particular saw a great proliferation of works recording traditional stories and customs. ${ }^{153}$

By the nineteenth century there was little attempt to use folk beliefs to make

150 See Withers, Geography, Science and National Identity, 87-94.

151 Killick, British Short Fiction, 122.

152 Ibid., 122, 16, 33, 121.

153 For example, Allan Cunningham, Traditional Tales of the English and Scottish Peasantry, 2 vols. (London, 1822); Robert Chambers, Traditions of Edinburgh (Edinburgh, 1824); Robert Chambers, The Book of Days, A Miscellany of Popular Antiquities (London, 1863-4); Robert Chambers, The Picture of Scotland, 2 vols. (Edinburgh, 1827); William Grant Stewart, The Popular Superstitions and Festive Amusements of the Highlanders of Scotland (Edinburgh, 1823); Hugh Miller, Scenes and Legends of the North of Scotland, or The Traditional History of Cromarty (Edinburgh, 1835); John Graham Dalyell, The Darker Superstitions of Scotland: Illustrated from History and Practice (Edinburgh, 1834); John Wilson, Lights and Shadows of Scottish Life (Edinburgh, 1822); Andrew Picken, Tales and Sketches of the West of Scotland (Glasgow, 1824); James Denniston, Legends of Galloway: Being a Series of Traditions, Illustrative of Its Ancient History, Customs, Manners, and Superstitions (Edinburgh, 1825); John MacCulloch, The Highlands and Western Isles of Scotland, 4 vols. (London, 1824). 
religious arguments. Ghosts still returned to seek revenge or right wrongs, and several authors noted their value as moral safeguards when 'the devotional sentiment $\ldots$ is either undeveloped or misdirected' ${ }^{154}$ However, there was no attempt on the part of the nineteenth-century folklorists to manipulate their readers into believing the ghosts' messages. The authors kept a sceptical distance, and there was a clear assumption that the reader would do the same. The new agenda was the project of nation-building. Despite the fact the folkloric investigations of the late seventeenth and early eighteenth centuries corresponded with a surging interest in geography, it is notable that the nineteenth century accounts conveyed a much stronger sense of place. Wodrow's and Sinclair's stories were presented as proof of supernatural phenomena rather than as reflections on the specific locale from which they originated, and their ghosts generally haunted people rather than places. The folklore of the early nineteenth century was much more likely to be tied to a certain geographical location. Even the ghosts themselves were often rooted to, and defined through, aspects of the scenery: Anne Macvicar Grant described the 'mountain ghosts', while Hugh Miller focused on the 'church-yard ghost'. ${ }^{155}$ David Stewart of Garth noted the way in which stories were tied to the Highland landscape, writing:

we still meet with Highlanders who can give a connected, and minutely accurate detail of the history, genealogy, feuds, and battles of all the tribes and families in every district, or glen, for many miles round, and for a period of several hundred years; illustrating their details by a reference to every remarkable stone, cairn, tree, or stream, within the district; connecting with each some kindred story of a fairy or ghost, or the death of some person who perished in the snow, by any sudden disaster, or by some accidental rencounter; ${ }^{156}$

This process happened in part because gothic literature had popularised the notion of haunted castles and churchyards (the former, in particular, do not seem to have been particularly common before the latter half of the eighteenth century). However, it is also evidence of how the practice of nation-building through culture and folklore had

154 Hugh Miller, Scenes and Legends of the North of Scotland; Or. The Traditional History of Cromarty, 2nd edn (London, 1850), 353.

155 Anne MacVicar Grant, Essays on the Superstitions of the Highlanders of Scotland, 2 vols. (London, 1811), i, 224-5; Miller, Scenes and Legends, 2nd edn, 353.

156 David Stewart, Sketches of the Character, Manners, and Present State of the Highlanders of Scotland, 2 vols. (Edinburgh, 1822), i, 93. 
evolved. The result was that ghosts were associated more strongly both with their local communities, and with Scottish culture more broadly.

Geography also played an increasingly important role in shaping visions of ghosts. This is particularly evident in the case of the Highlands. Highland ghosts were presented as being ancient and warlike - or at least, as having been so in the past. William Grant Stewart wrote: 'Unlike the present puny, green, worm-eaten effigies that now-a-days stalk about our premises, and, like the cameleon, feed upon the air, the ancient race of Highland ghosts were a set of stout, lusty, sociable ghosts'. They were usually corporeal. A ghost would 'do as much justice to a bicker of Highland crowdie as his earthly contemporaries', and was supposed to be 'material in its nature, quite susceptible of mortal pain, and liable to death or annihilation from the weapons of man'. ${ }^{157}$ John MacCulloch presented a somewhat more complicated picture, but still insisted on elements of corporeality:

Sometimes they seem pure spirit; at others, they have corporeal properties, or they unite the spiritual and the corporeal essences in one. They are formed of thin air, and disappear in smoke; on many more authorities than those of Ossian and Macpherson. If they are also immortal, as Ghosts ought to be, they sometimes die and are buried. They may also be killed. They are hard, because they pull a man's hair and box his ears; and heavy, because they must sometimes be lifted from the ground; when they resist, being tangible and ponderable. ${ }^{158}$

Although some ghosts were said to be 'moral, rational and prudent', most were 'illnatured and cruel', and liked to pick fights with travellers: 'The warlike bogle of the last century carried about with him flails, cudgels, and such other pithy weapons as were suitable to the spirit of the times, and on his meeting with a human adventurer who had no objection to become his antagonist, his choice of weapons was left with the latter' ${ }^{159}$ These ghosts were broadly similar to revenants, but although they had bodies and could eat, drink and fight, they were not usually depicted as actual corpses risen from graves. They also tended to appear over a long time-span, perhaps centuries. In contrast, revenants usually rose soon after death, while vital forces were

157 Stewart, Popular Superstitions, 5, 12.

158 MacCulloch, Highlands and Western Isles, iv, 335.

159 Grant, Essays on the Superstitions, i, 225; Stewart, Popular Superstitions, 6, 22. 
thought to remain in the body, and rarely visited over an extended period of time. The influence of the Ossian poetry on this vision of the ghost is clear. As we shall see in the next chapter, it is questionable whether warlike Highland ghosts were part of Gaelic culture at all before Macpherson popularised the idea. Second sight apparitions seem to have been significantly more common than ghosts before authors such as Collins began to transform the former into the latter. As with other aspects of the romanticisation of the Highlands, accurately reflecting tradition was not the first priority.

In a discussion of the invention of tradition, Hugh Trevor-Roper suggests that 'the whole history of Scotland has been coloured by myth', and that 'myth, in Scotland, is never driven out by reality, or by reason, but lingers on until another myth has been discovered, or elaborated, to replace it'. ${ }^{160}$ Certainly, Macpherson's vision of the Gaelic past was as mythical as his ghosts, and the nineteenth-century image of Highland culture was similarly idealised. For Colin Kidd, the rejection of the Ossianic origin stories ended the possibility of true Scottish Gaelic patriotism. The 'kitsch Gaelic identity' that emerged instead was 'a tame accessory of British unionism and imperialism, and did nothing to restore to Scots a powerful ethnocultural identity'. ${ }^{161}$ This argument is reinforced by the relative harmlessness of the ghost stories recorded by the early nineteenth-century antiquarians. The ghosts were neither the subversive figures of eighteenth-century poetry, nor representatives of a noble Celtic past. Highland spectres were quaint, charming relics of the now-pacified region. The nineteenth-century romantic project, in the most unsympathetic reading, was no more than an imperialist process of cultural appropriation and rewriting that coincided with the genuine Highland way of life being brutally dismantled in the name of 'Improvement'. ${ }^{162}$

This criticism is both valid and important. Nevertheless, to dismiss the romantics'

160 Hugh Trevor-Roper, The Invention of Scotland: Myth and History (New Haven, 2008), xx.

161 Colin Kidd, 'Gaelic Antiquity and National Identity in Enlightenment Ireland and Scotland', English Historical Review, cix (1994), 1214.

162 Clyde, From Rebel to Hero, ch. 2; Devine, Scottish Nation, 244; Evan Gottlieb, Feeling British: Sympathy and National Identity in Scottish and English Writing, 1707-1832 (Lewisburg [Pa.], 2007), 162; McNeil, Scotland, Britain, Empire, 14-15. 
nation-building as either inconsequential, or as a purely destructive process, is to ignore the very real power of myth. An identity built on stories is not necessarily any less meaningful than an identity built on historical evidence and charts of lineage. Politically, the project of building Scottish identity ran aground in the early nineteenth century. When nationalism became a force in Scotland, it was within the context of union. ${ }^{163}$ This period did, however, see the development of a specifically Scottish cultural identity. As Katie Trumpener has shown, the the legends created and relayed by bards were a valid way of maintaining national distinctiveness within an imperial framework, even when they were recognised to be largely fictional. ${ }^{164}$ Ghosts became a facet of the national image. Admittedly, for the majority of the folk they were probably associated with local, rather than national, identity. Furthermore, not all antiquarians presented them as national symbols: MacCulloch stressed that the Highlanders did not have 'any peculiar claims on their own tales and superstitions', but that similar beliefs could be found throughout Europe. ${ }^{165}$ By the time MacCulloch was working, however, it was too late to get away from the sentimental vision of Gaelic culture that Macpherson had popularised. Most folklorists simply embraced it. William Grant Stewart opened his account of Highland ghosts by situating them within a national framework: 'ghosts have been, at all times, a plentiful commodity among the hills of Caledonia'. ${ }^{166}$ Whether or not there was any truth in this picture, it reflected a reputation that would not be easily dislodged.

\section{Belief}

Finally, it is worth considering how fiction and antiquarian studies reflect on the question of belief. The most obvious conclusion is that ghosts were popular, but they were not generally taken to be objective realities. The ghosts of gothic and romantic literature were not offered up as real specimens, but were understood as a shorthand into a certain world, in which the reader was expected to suspend his or her disbelief.

163 See Morton, Unionist-Nationalism.

164 Trumpener, Bardic Nationalism. See the preface for a summary of this argument.

165 MacCulloch, Highlands and Western Isles, iv, 323.

166 Stewart, Popular Superstitions, 4. 
As we have seen, psychological ghosts were common, and many authors mentioned dreams, trances, guilty consciences, the power of imagination and 'the glance of fancy's fearful eyes'. ${ }^{167}$ Ghosts were acknowledged to be the preserve of the 'wrinkled Grandam' and 'ancient gossips', or the

timorous school-boy, madly fear'd

By many a rueful story often heard, ${ }^{168}$

When Alexander McDonald's Vimonda was first performed in 1787, an epilogue was added that made the triumphant declaration:

Now, thank our stars! the childish creed is lost,

That gave such mighty influence to a ghost. ${ }^{169}$

The nineteenth-century folklorists also maintained a sceptical distance. Whereas Wodrow, Sinclair and Kirk had sympathy for the stories they recorded, and Martin was a believer in second sight, their nineteenth-century counterparts saw their stories as mere curiosities. William Grant Stewart drew clear lines between his storytellers and his readers:

Nothing can appear more surprising to the refined reader, than that any human being, possessing the rational faculties of human nature, could for a moment entertain a notion so preposterous, as that a ghost, which conveys the idea of an immortal spirit, could be killed, or rather annihilated, by an arrow, dirk, or sixpence. It was, however, the opinion of the darker ages, that such an exploit as killing a ghost was perfectly practicable ... Such an opinion is repeatedly expressed in several passages of the Poems of Ossian, and in the doctrine of the Seanachy, down to the present day. ${ }^{170}$

By 1822, the poet and author Allan Cunningham had one of his characters complain that, whereas once tales and ballads of ghosts and other creatures 'would have been to one as food and raiment and white money', in modern times 'the wisdom of man so much abounds, that he is pleased with nought; he laughs at ancient beliefs, and

167 John Copland, Saint Andrews: Or, a Sentimental Evening Walk near the Ruins of That Ancient City (Edinburgh, 1776), 38.

168 Ibid., 39.

169 Mr MacKenzie, 'Epilogue to Vimonda', Universal Magazine, Sept. 1787, 155.

170 Stewart, Popular Superstitions, 12. A 'Seanachy' was an antiquarian or story-teller. 
calls for ocular proof, and testimony on oath, and the assurance of many witnesses, for all oral or recorded things'. ${ }^{171} \mathrm{~J}$. Mitchell and John Dickie similarly declared in 1839 that 'The superstition of the existence and re-appearance of ghosts ... [is] now being rapidly chased from the realities of existence, and the thousand miseries which flowed from a belief in unproved and unknown beings, like the mountain mists, are vanishing before the light of the sun of science'. ${ }^{172}$

This picture of scepticism should not be over-emphasised, however. Some of the romantics may have believed in ghosts. The poet James Thomson, who made occasional mentions of ghosts, was said to be afraid of them (a story would later circulate that his father was killed while trying to exorcise a ghost). ${ }^{173}$ Scott adopted a sceptical stance in Letters on Demonology and Witchcraft, and wrote contemptuously of how he had heard the Lord Chancellor Erskine 'tell a cock-and-a-bull story of having seen the ghost of his father's servant, John Burnet, with as much gravity as if he believed every word he was saying'. ${ }^{174}$ Nevertheless, he described himself as 'an initiated Ghost-Seer' and 'ghost-raiser' in private correspondence. ${ }^{175}$ One article in Blackwood's argued:

It is possible that the greater part of [appearances from the world of spirits] may be merely the delusions of the senses, or unreal images, conjured up by an excited imagination; but the sceptical assertion of the non-existence and non-appearance of the spirits of the departed, is not confirmed by human experience, or by human history ... I think it neither unchristian nor unphilosophical, to entertain a qualified belief in the occasional appearance of beings from the invisible world. ${ }^{176}$

Another Blackwood's contributor noted that 'Ghosts ... in spite of all that philosophy can do, have taken such a place in the imaginations, and, indeed, in the hearts of men, that their total banishment from thence must for ever remain an

171 Cunningham, Traditional Tales, ii, 45.

172 J. Mitchell and John Dickie, The Philosophy of Witchcraft (Paisley, 1839), 355.

173 James Sambrook, James Thomson, 1700-1748: A Life (Oxford, 1991), 10-11.

174 Quoted in Lockhart, Memoirs of the Life of Sir Walter Scott, ix, 318.

175 Fiona Robertson, Legitimate Histories: Scott, Gothic, and the Authorities of Fiction (Oxford, 1994), 54; Michael Gamer, 'Gothic Fictions and Romantic Writing in Britain', in Jerrold E. Hogle (ed.), The Cambridge Companion to Gothic Fiction (Cambridge, 2002), 92.

176 'The Voyages and Travels of Columbus Secundus', Blackwood's Edinburgh Magazine, Nov. $1821,398$. 
impossibility'. ${ }^{177}$ As we have seen, ghosts did not need to be real to be presented as objects of terror. Numerous authors insisted that everybody felt a shudder when walking through a dark graveyard. As one writer explained: 'truly and emphatically may it be said, that the stout man who is so ingenious as to contrive stories of apparitions when sitting in a large company round the fireside, feels a little compunction, as well as palpitation, when he comes to reflect, in the glooms of solitude, on the sportability of his imagination'. ${ }^{178}$ When ghosts were such a wellestablished trope, they could cross the boundaries between fiction and reality, even for those inclined towards scepticism. Travelling through Scotland in 1784, William Thornton saw a vision of an old man with white hair in a floating white drapery, and promptly exclaimed: 'It is Ossian! ... It is that divine poet himself'. ${ }^{179}$

According to one common standpoint, it did not much matter whether or not ghosts existed, as they had a significant role in society regardless. Their value within literature and poetry was underlined: Scott noted that 'a supernatural tale is in most cases received as an agreeable mode of amusing society, and he would be rather accounted a sturdy moralist than an entertaining companion who should employ himself in assailing its credibility'. ${ }^{180}$ The Blackwood's article on 'qualified belief' continued:

But even allowing the existence and appearance of ghosts, spirits and fairies of every description to be questionable, their use in Poetry and Romance, and their higher moral purpose in deterring from crime those who are not to be restrained by other considerations, render a belief in their agency a desirable part of the code of faith among civilized nations.

It was said that there was no topic 'upon which, in all classes, talkers are so little apt to tire', whether or not these talkers actually believed in spectres. ${ }^{181}$ One author wrote

177 'Devil's Elixir', 56.

178 William Harley, 'The Mentor', Asylum or Weekly Miscellany, 3 vols. (Glasgow, 1795-6), i, 204. See also Mitchell and Dickie, Philosophy of Witchcraft, 351.

179 Barthélemy Faujas de Saint-Fond, A Journey through England and Scotland to the Hebrides in 1784, ed. and trans. Archibald Geikie, 2 vols. (Glasgow, 1907), i, 311. On this theme see Handley, Visions of an Unseen World, 181; Womack, Improvement and Romance, 110.

180 Walter Scott, Letters on Demonology and Witchcraft (London, 1830), letter x, 356.

181 'Voyages and Travels of Columbus Secundus', 399; 'A Chapter on Goblins', Blackwood's Edinburgh Magazine, Dec. 1823, 639. 
that he had, in effect, chosen to believe in ghosts. He owned that it might be a positive thing to feel no fear in a mysterious house or a graveyard, but insisted it would not be worth sacrificing the thrill of a ghost story by the Christmas fireside, 'the more exalted sense which a lurking tendency to superstitious apprehension adds to our relish of the sublime in poetry', or the undertones of pleasure that accompanied supernatural terror. ${ }^{182}$

Furthermore, while the eighteenth century saw significant emphasis on the notion of 'reason', the latter half of the century was also when the 'cult of sensibility' was at its most influential. This movement celebrated the sentimental elements of romantic literature, and viewed intense emotional reactions as a mark of refinement. ${ }^{183}$ Women were thought to be particularly susceptible to strong emotion, a stereotype displayed in Gothic heroines such as Orra and Vimonda. Alexander Gerard, professor of moral philosophy in Aberdeen, explained in 1759: 'Great sensibility of taste is generally accompanied with lively passions. Women have always been considered as possessing both in a more eminent degree than men. ${ }^{184}$ However, as Clare Knowles argues, "the seeming "naturalness" of feminine sensibility was complicated significantly by the fact that writers expressed sensibility through, and readers recognised sensibility in, a set of conventional tropes and poses which ... could become a costume that one might put on at will'. ${ }^{185}$ Sensibility was described within the periodical press as 'the last finishing, and highest polish of the female character'; there was clear motivation for women to affect it. ${ }^{186}$ Just as the Blackwood's commentator chose to shiver at the supernatural in order to enjoy tales of terror, elegant ladies (and, perhaps, gentlemen) might have considered it befitting to be afraid of ghosts.

182 'Phantasmagoriana', Blackwood's Edinburgh Magazine, Aug. 1818, 590.

183 See Janet Todd, Sensibility: An Introduction (London, 1986); G. J. Barker-Benfield, The Culture of Sensibility: Sex and Society in Eighteenth-Century Britain (Chicago, 1992); Markman Ellis, The Politics of Sensibility: Race, Gender and Commerce in the Sentimental Novel (Cambridge, 1996).

184 Alexander Gerard, An Essay on Taste (London, 1759), sec. vi, pt. iii, 200.

185 Claire Knowles, Sensibility and Female Poetic Tradition, 1780-1860: The Legacy of Charlotte Smith (Farnham, 2009), 184.

186 'A Conversation on Female Accomplishments', Edinburgh Magazine, or Literary Miscellany, May 1796, 365. 
The question of belief, overall, is very difficult to unpick. The cultural trends in the latter half of the eighteenth century pushed in opposite directions simultaneously. It was a period when ghost believers were ridiculed and satirised as never before. Nevertheless, ghost stories were immensely popular, even among the satirists. There was perhaps an element here of trying to have your cake and eat it, and Anne Macvicar Grant's summary was scathing:

These lovers of the awful and terrible, affected the highest contempt for the honest believers who trembled at ghosts they thought real; yet they were no otherwise superior to them, than the puppies who bark at the reflection of the moon in a pond, are to the dogs who, with more originality and better directed energy, bark at the moon herself. ${ }^{187}$

However, as a folklorist, Grant herself was not free of a similar double standard. The nineteenth-century antiquarian movement also combined a sceptical attitude towards ghosts with a marked interest in popular ghost legends. Perhaps the most useful conclusion that can be drawn is that the ontological status of ghosts was not of great importance. For believers and non-believers alike, they had become an established feature of the Scottish cultural landscape.

\section{Conclusion}

The development of fiction and folklore in the eighteenth and early nineteenth centuries gave ghosts a new lease of life. With the evolution of gothic themes in literature, ghosts became fashionable as atmospheric devices. Aesthetic features took on a new centrality: ghosts' appearances were explored in poetic terms, and the ghosts themselves were set in a dramatic light. This was further developed through the sublime, sorrowful phantoms of the Ossian poetry. By the nineteenth century the romanticised ghost was a staple of the Scottish literary world, and could assume a rich variety of guises, as can be seen in the work of Scott and Hogg. For all the focus on aesthetics, however, ghosts were more than mere elements of the scenery. As they

187 Grant, Essays on the Superstitions, i, 301. 
shed their demonic connotations and became more secularised (at least within the literary world), there was scope for ghosts to be used in new ways, employed on their own terms rather than as servants to God or the Devil. Gothic ghosts played on the natural human fear and fascination regarding death. The death they presented was not a happy passage to the afterlife, nor a natural medical process, but something grotesque and tragic - as well as oddly seductive. The second half of the eighteenth century emphasised psychological explanations for ghosts, but here too gothic writing reintroduced an element of terror, exploring the murky depths of mental illness. Ghosts were powerful symbols, whether or not they were objective realities. As one of Scott's characters explained: 'All that is indispensable for the enjoyment of the milder feeling of supernatural awe is, that you should be susceptible of the slight shuddering which creeps over you when you hear a tale of terror'. ${ }^{188}$

Ghosts also contributed to the romantic project of nation-building. They were used to explore the past in relation to the present, and to glorify and mourn a magical, bygone Scotland. The post-Union development of a backwards-looking nationalism, along with the growing importance of the romantic and gothic aesthetics, meant that ghosts were peculiarly well-suited to the cultural context of the eighteenth and early nineteenth centuries. Antiquarians increasingly associated ghosts with local areas and features of the Scottish landscape, and a Highland ghost developed that played on the stereotypes of the region. Although not all ghosts were distinctly Scottish, the eighteenth century saw the development of the specifically Scottish ghost as a concept. While Scotland has been criticised as a mere 'romantic object or commodity', this was a process of self-fashioning that happened within the country, part of a 'middle-class response to the demand for nostalgia in an increasingly urbanized and industrialized society'. ${ }^{189}$ Ramsay, Smollett and other writers might satirise the ghost belief of the lower classes, and antiquarians might underline the divides between polite and vulgar, Lowland and Highland. Nevertheless, popular

188 Scott, 'My Aunt Margaret's Mirror', 11.

189 Richard J. Finlay, 'Caledonia or North Britain? Scottish Identity in the Eighteenth Century', in Dauvit Broun, Richard J. Finlay, and Michael Lynch (eds.), Image and Identity: The Making and Re-Making of Scotland through the Ages (Edinburgh, 1998), 153. Finlay is not referring specifically to ghost stories, but to the 'Highlandization of Scottish culture and the celebration of rural values' (ibid.). 
belief was valued as proof that Scotland maintained its own traditional culture. The process of tying national identity to rural culture, especially Highland culture, allowed the Scots to 'reap all the benefits of Union, while at the same time retaining a location for all the virtues of sturdy independence'. ${ }^{190}$ Evidence of Scottish cultural distinctiveness could be called upon at will, whether in aid of a pro- or anti-unionist agenda. This was significant even if many of the emblems of Scottishness were fabricated. Ghosts, in fact, are fitting symbols for the romantic project as a whole. They may have been mythical, but it did not much matter; they had power regardless.

190 Malcolm Chapman, The Gaelic Vision in Scottish Culture (London, 1978), 13. 


\section{Chapter Five}

\section{Ghosts in Popular Culture}

Stories were told long before they were written down. The historian is always constrained by the limitations of written records, but this is particularly evident when it comes to looking at popular belief: it is difficult to determine the place of ghosts in Scottish culture when, for centuries, few considered ghost stories worth recording. Matters improve somewhat over the course of the eighteenth century. The end of the witch trials removes one body of sources, but this is outweighed by the development of print culture and antiquarian studies. This chapter uses ballads, cheap pamphlets and folklorists' accounts to assess popular perceptions of ghosts (although these three categories are not perfectly delineated: most obviously, ballads were often printed as broadsides). All of these bodies of sources have drawbacks, however. Ballads offer the most direct window into folk culture, but they are difficult to trace and date. Cheap print culture is useful because it was targeted at a popular market, and could be read aloud, meaning that it was accessible to the illiterate as well. Adam Fox, Edward J. Cowan and Mike Paterson have demonstrated how cheap print can be used as a window into Scottish popular culture. ${ }^{1}$ However, pamphlets were still composed by educated folk, and it is difficult to judge how far they circulated. Finally, folklorists' accounts have obvious value, but come diluted by the perceptions and preoccupations of their author. This chapter takes a broad view of popular culture: it includes stories that were produced by and for elites provided that they were demonstrably widespread in Scottish society. The aim of the chapter is not to avoid educated culture altogether, but to assess the ways in which ghosts were perceived by the majority of the Scottish population.

1 Edward J. Cowan and Mike Paterson (eds.), Folk in Print: Scotland's Chapbook Heritage, 17501850 (Edinburgh, 2007); Adam Fox, 'The Emergence of the Scottish Broadside Ballad in the Late Seventeenth and Early Eighteenth Centuries', Journal of Scottish Historical Studies, xxxi (2011), 169-94; Adam Fox, "Little Story Books" and "Small Pamphlets" in Edinburgh, 1680-1760: The Making of the Scottish Chapbook', Scottish Historical Review, xcii (2013), 207-30; Adam Fox, 'Approaches to Ephemera: Scottish Broadsides, 1679-1746', in Kevin Murphy and Sally O’Driscoll (eds.), Studies in Ephemera: Text and Image in Eighteenth-Century Print (Lanham, 2013). 
Ballads were an important feature of Scottish folk culture, and circulated in print as well as via oral culture. ${ }^{2}$ Ghosts were not a central theme, but did emerge with reasonable frequency: Lizanne Henderson notes that fourteen of the 305 ballads collected by Francis James Child are concerned with ghosts or revenants, and a further four feature a magical corpse. ${ }^{3}$ Few ballads can be accurately dated, and most of those recorded in the eighteenth and nineteenth centuries were probably significantly older. This is suggested, at least, by their presentation of ghosts. The ballad ghosts echo medieval traditions. They tend to be corporeal: they feel hunger, thirst, pain and sexual desire. In 'The Wife of Usher's Well' (Child 79), a mother knows that her dead sons will return and prepares a feast and soft beds. When they appear, they claim to be in pain. ${ }^{4}$ Furthermore, ghosts often arrive fresh from their graves. The ghost of Clerk Saunders (Child 69), on meeting his sweetheart Margaret, explains that he has come 'frae 'neath the darksome grund'. When Margaret wonders what has become of his 'bonnie arms', he declares:

By worms they're eaten; in mools they're rotten;

Behold, Margaret, and see;

And mind, for a' your mickle pride,

Sae will become o' thee! ${ }^{5}$

Ballad ghosts might also be violent. 'Willie's Fatal Visit' (Child 255) tells of a young man who spends the night with his lover. The cock crows early and he mistakes the moonlight for daylight, leaving her house before sunrise. He meets a ghost who accuses him of sinful behaviour, and before dawn she has

Riven him frae gair to gair,

2 Useful literature on this topic includes Hamish Henderson, 'The Ballad and Popular Tradition to 1660', in R. D. S. Jack (ed.), The History of Scottish Literature, Vol. 1: Origins to 1600 (Aberdeen, 1988); Emily Lyle (ed.), Scottish Ballads (Edinburgh, 1994); Edward J. Cowan (ed.), The Ballad in Scottish History (East Linton, 2000).

3 Lizanne Henderson, 'The Road to Elfland: Fairy Belief and the Child Ballads', in Edward J. Cowan (ed.), The Ballad in Scottish History (East Linton, 2000), 55.

4 Francis James Child, The English and Scottish Popular Ballads, 5 vols. (Boston, 1882-98), ii pt. i, 239.

5 Robert Chambers, The Scottish Ballads (Edinburgh, 1829), 241. 
And on ilka seat o' Mary's kirk

O’ Willie she hang a share. ${ }^{6}$

'The Miller and the King's Daughter' (also known as 'The Twa Sisters'; Child 10) gives the story of two sisters. They are playing near some water when the elder pushes the younger in, killing her. A miller later comes across the dead body and crafts it into a violin. The breast bone is used as the body of the instrument, the fingers as pegs, the nose ridge as a bridge, and the veins as strings. When it is played, the violin speaks, and in traditional ghost fashion identifies herself and her murderer. ${ }^{7}$ The dead body parts retain their identity, and are able to exert some degree of power. Furthermore, several ballads feature talking corpses. In 'Young Benjie' (Child 86), when a young woman is killed, her brothers resolve that to discover the perpetrator they must wait until midnight (ghosts usually appeared after dark, and often at the stroke of midnight). As the brothers expect, at 'the dead hour o the night' the corpse revives and identifies her murderer. ${ }^{8}$ Another common theme was the idea that the dead body had such potency, it was actually poisonous to the living. In the 'Twa Brothers' (Child 49), when a woman requests a kiss of her dead love, she receives the following reply:

'My lips they are so bitter,' he says,

'My breath it is so strong,

If you get one kiss of my ruby lips,

Your days will not be long."

Identical or very similar lines appear in 'Sweet William's Ghost' (Child 77) and 'The Unquiet Grave' (Child 78). Ballads thus reinforced popular notions about the innate power of the dead body, and recalled medieval ideas of the corporeal revenant.

Some ballads did offer romanticised ghosts, that came 'gliding' and wore white shrouds, but it is likely that they were composed later. ${ }^{10}$ One version of the traditional

6 Peter Buchan, Ancient Ballads and Songs of the North of Scotland, 2 vols. (Edinburgh, 1828), ii, 261-2.

7 Child, English and Scottish Popular Ballads, i pt. i, 118.

8 Ibid., ii pt. ii, 283.

9 Ibid., i pt. ii, 439.

10 M., 'Robert and Margaret: A Ballad', Weekly Magazine, or Edinburgh Amusement, 1 Feb. 1776, 
ballad 'Sweet William's Ghost' (Child 77) presents an incorporeal ghost, who claims to be a mere spirit and vanishes 'in a cloud of mist'. ${ }^{11}$ However, these lines appeared in only one version, which likely dated from the nineteenth century. In another (probably earlier) version, the ghost actually walks to his grave when his visit is over, and lies down therein. ${ }^{12}$ Another romanticised ghost can be seen in the ballad 'William and Margaret', which was probably written by Scottish dramatist David Mallet around $1723 .{ }^{13}$ The ballad presents the ghost of a woman returning to reproach her faithless lover:

'Twas at the silent Midnight-Hour, When All were fast asleep;

In glided Margaret's grimly Ghost, And stood at William's Feet.

Her Face was like an April Morn, Clad in a wintry Cloud:

And Clay-cold was her Lilly Hand, That held her sable Shroud.

Despite the romantic elements, Margaret implies that she had returned from the grave, noting 'The hungry Worm my Sister is'. ${ }^{14}$ Furthermore, the 'clay cold' of her hand suggests a degree of corporeality. The sable shroud, incidentally, is an unusual feature - ghosts generally chose white over black - but it was perhaps chosen for poetic reasons, presenting a striking contrast with the 'lilly hand'. Mallet presents a more picturesque ghost, but still acknowledges the ballad tradition of depicting ghosts as revenants. While in elite culture the revenant had fallen out of fashion, replaced first by the ghost as a servant of God and secondly by the ethereal ghost, the ballads demonstrate the survival of older folkloric themes.

In the ballads ghosts occasionally came back to reveal their murderers or speak of the

178.

11 Child, English and Scottish Popular Ballads, ii pt. i, 228-9.

12 Ibid., ii pt. i, 230-1. See Lowry Charles Wimberly, Folklore in the English and Scottish Ballads (Chicago, 1928), 228.

13 See David Atkinson, “William and Margaret”: An Eighteenth-Century Ballad', Folk Music Journal, x (2014), 478.

14 David Mallet, The Excursion: A Poem (London, 1728), bk. ii, 75-80. 
afterlife, but this was not the dominant pattern. More usually they returned simply to visit family members or lovers. They also reflected on the nature of death. David Buchan argues that the principle purpose of ballad ghosts was to caution against an improper degree of grieving. ${ }^{15}$ In 'The Twa Brothers' (Child 49), a ghost pleads with his love:

O cease your weeping, my true-love,

And 'twill gie peace to me. ${ }^{16}$

These ghosts did, therefore, bear a broadly Christian message: death should be accepted with equanimity. However, they tended not to make mention of God, Heaven or Hell. Ghosts might have been useful as religious propagandists, political commentators or atmospheric devices, but the ballads serve as a reminder that they also survived for more straightforward reasons. With life expectancy hovering somewhere around thirty in the mid-eighteenth century, death was a familiar beast. ${ }^{17}$ The ballad ghosts were a response to it. They underlined the inevitability of death, as we see with Clerk Saunders's reminder to Margaret that 'Sae will become o' thee'. Furthermore, in contrast to the rather prettified death frequently seen in Gothic poetry, ballads relished the goriness of rotting limbs, gluttonous worms and poisoned lips. There was more raw realism in this picture than the kirk's sanitised version of the resurrection of the dead, which held bodies would 'arise incorruptible'. ${ }^{18}$ The ballads did not sentimentalise death, but presented it as a part of the natural order that should be borne with fortitude, positing that prolonged grieving would only disturb the dead. The argument that the dead could be affected beyond the grave by the grieving (or prayers) of the living was also out of line with Protestant doctrine, but it was a message that appealed on an emotional level, unlike the kirk's teaching that the living were completely cut off from the dead. The ghosts of ballads provided a way for communities to explore and contend with death, keeping roughly in line with

15 David Buchan, 'Talerole Analysis and Child's Supernatural Ballads', in Joseph Harris (ed.), The Ballad and Oral Literature (Cambridge [Mass.], 1991), 75. See also Henderson, 'Road to Elfland', 68.

16 Child, English and Scottish Popular Ballads, i pt. ii, 440.

17 R. A. Houston and I. D. Whyte, 'Introduction: Scottish Society in Perspective', in R. A. Houston and I. D. Whyte (eds.), Scottish Society, 1500-1800 (Cambridge, 1989), 4.

18 Arthur C. Cochrane (ed.), 'The Scottish Confession of Faith, 1560', Reformed Confessions of the Sixteenth Century (Philadelphia, 1966), 184. 
Christian doctrine without being overly restricted by kirk directives.

\section{Cheap Print Market}

The expansion of print culture in the eighteenth century opened up a new avenue for ghost stories. Broadsides and chap-books were sold cheaply on the street, at markets and at fairs. As in the case of ballads, ghosts did not appear with great frequency, but they did feature from time to time. The National Library of Scotland's online collection of about 1,800 Scottish broadsides printed between 1650 and 1910 includes a dozen broadsides that feature apparitions, most from the eighteenth and early nineteenth centuries. ${ }^{19}$ Another few dozen eighteenth-century pamphlets or chap-books featuring ghosts have been preserved. Titles such as The Laird of Coul's Ghost and Thrummy Cap and the Ghaist became popular, as well as ghost stories from Scott, Hogg and other authors. ${ }^{20}$ Some ghost stories were told in prose, some in verse. Ghosts were often used as tragic or comical devices, but might also be presented as objective realities. A 1722 broadside declared: 'Whatever the World may think of Apparitions and Spectres, 'tis very certain, such has been before, and learned Divines still own the same Exist, and have appeared in the several past Ages'. There was no reason, it continued, that God should not 'make use of the Ministry of Spirits' to foretell extraordinary events, punish the guilty or manifest his will. ${ }^{21}$ For the most part, however, pamphlets made little attempt to justify their ghosts: the central focus was on the story itself.

The presentation of ghosts varied. The revenant-like ghost of the ballads appeared with reasonable frequency, partly because popular ballads such as 'Sweet William's Ghost' were themselves printed. A broadside from around 1680 featured the speech of the ghost of a Fife laird, and depicted him walking from the grave:

What accident, what strange mishap,

19 The Word on the Street (NLS, 2004), http://digital.nls.uk/broadsides, accessed 1 Aug 2015.

20 Cowan and Paterson, Folk in Print, 30-1.

21 The St. James's Surprizing and Afrightful Apparition ([Edinburgh?], 1722). 
Awakes me from my heavenly nap?

What sprit? what God-head by the lave,

Hath rais'd my Body from the Grave? ${ }^{22}$

Occasionally ghosts returned bearing wounds. One ghost was 'Streaming with blood, and pale as the sheeted inmates of the tomb'. ${ }^{23}$ A couple of pamphlets even presented headless ghosts, reminiscent of the apparition of Fawdon, but otherwise not a typical pattern in Scottish ghost stories. ${ }^{24}$ 'MacKinnon's Ghost' offers a particularly colourful example of a wounded ghost. Mary MacKinnon was executed for murder in 1823. 'MacKinnon's Ghost' gives her story in ballad form, with the stipulation that it should be sung to the tune of 'Margaret's Ghost' (another title for Mallet's aforementioned 'William and Margaret'). MacKinnon returns with her face cut by the anatomizing knife, and her hand 'drench'd with native gore'. Her breast displays 'the scalpel's gash', and she speaks slowly in 'strangled accents'. Her face is said to be black and 'deformed with many a wound', and she declares to the friend she was visiting:

Behold my tongue, half bitten through,

That daily lied and curst-

And mark mine eyes, lascivious blue,

From forth their sockets burst.

Behold my carcass, hack'd and flay'd, Which round and sleek should be-

And then bethink thee, careless jade, The same may hap to thee! $!^{25}$

MacKinnon's body serves as a canvas on which her sins are displayed. The grotesque nature of the revenant is harnessed for dramatic effect, producing vivid and memorable imagery, as well as underlining the moralising message of the piece. The

22 P. M., The Speech of a Fyfe Laird, Newly Come from Grave ([Scotland], [1680?]).

23 The Vision of Dr Morris, Or, The Spectral Warning ([Edinburgh], 1821).

24 See, for example, A Full True and Particular Account of the Most Dreadful Apparrition: Of Robert Watt Wine-Merchant in Edinr, Who Appeared to James Macdonald Plaisterer in LiethWalk ([Edinburgh?], [1794?]). Scottish headless ghosts are briefly discussed in 'Sketches of Superstitions', Chambers's Edinburgh Journal, 10 Apr. 1841, 94.

25 MacKinnon's Ghost ([Edinburgh? ], [1823?]). While the ballad itself is not dated, it is likely that it was produced reasonably soon after the execution, while the case remained topical, and it was collected by James Maidment along with other printed materials from 1823. NLS, Ry.II.c.26. 
depiction of MacKinnon's ghost also reflects the horrors attached to the anatomy knife in the public imagination. Executed criminals were generally delivered to anatomists. Nonetheless, there was a shortage of corpses available for dissection, a deficiency that was addressed in part through a black market. Grave-robbing was a lucrative business, and in 1828 William Burke and William Hare ventured to greater depths of villainy by murdering sixteen people in order to sell their bodies. ${ }^{26}$ The references to the 'hack'd and flay'd' corpse play on the provocative terror of dissection. In elite culture the revenant was less fashionable than the ethereal, gliding ghost of romantic poetry, but the monstrous undead retained a place in the popular imagination, and could be employed to reflect on contemporary events and concerns.

The ghosts of pamphlet literature generally returned either in the clothes they had worn during their lifetimes, or in white. As we have seen, the ghosts of romantic literature frequently wore white, but the association between the dead and the colour white pre-dated this trend. White was a mourning colour, particularly for young women; Mary Queen of Scots was painted wearing a white veil when in mourning for her mother and father-in-law. ${ }^{27}$ In Revelations, the souls of the dead were given white robes, and Calvin wrote that 'white robes and rest are given us' in Abraham's Bosom. ${ }^{28}$ In addition, white winding-sheets or death dresses were commonly used for the dead. One broadside featured a 'hideous spectre, with a visage as white as snow, his hair clotted with blood, and clad in a white winding-sheet, so thin, that it did not conceal his body, mangled and torn in many places'. ${ }^{29}$ There was an element of the theatrical in the white-sheeted ghost, and this dramatic image was reinforced in other ways. Ghosts might depart amid peals of thunder and lightning; one 'flew off in a flame of fire' ${ }^{30}$ Two pamphlets presented ghosts who smelled of sulphur; to reinforce the association with Hell, one of them was 'accompanied with a gloomy light, much

26 There is a useful passage on this in Gillian Bennett, Bodies: Sex, Violence, Disease, and Death in Contemporary Legend (Jackson [Miss.], 2009), 223-8, but for an in-depth analysis see Ruth Richardson, Death, Dissection and the Destitute (London, 1987).

27 Roy Strong, Tudor and Jacobean Portraits, 2 vols. (London, 1969), i, 219; see Nigel Llewellyn, Art of Death: Visual Culture in the English Death Ritual c.1500-c.1800 (London, 1991), 89.

28 Rev 6:11, King James version; John Calvin, 'Psychopannychia', in Thomas F. Torrance (ed.), Tracts and Treatises in Defense of the Reformed Faith, 3 vols. (Grand Rapids, 1958), iii, 467.

29 An Account of a Most Horrid, Bloody, and Terrible Apparition, Which Lately Appeared in the Parish of Shotts (London, [1793?]).

30 Full True and Particular Account ... of Robert Watt. 
resembling in colour the blaze of brimstone'. ${ }^{31}$ Overall, the cheap print market explored a range of ghostly guises, but its depictions tended to be sensationalised.

Pamphlets and broadsides usually favoured moralising ghosts. One apparition came to reveal 'a most Horrid and Barbarous Murder and Robbery'; others warned of the torments of Hell, and one appeared to a friend to speak of the joys of Heaven. ${ }^{32}$ One pamphlet provided 'a dreadful example for wicked husbands', telling the story of a man who married a beautiful young lady against her friends' wishes. He spent their money in a 'riotous and debauched manner', was driven to despair and hanged himself. His apparition was then seen and heard for a long time, 'making terrible noises to the great terror and disturbance of the neighbourhood'. ${ }^{33}$ Again, there was an emphasis on drama and sensationalism. The upright moral message excused the pamphlets' spirited exploration of murder and debauchery. An Abstract of the Bloody Massacre in Ireland, published around 1700, offered a detailed and gory description of the killing of Protestants by Irish Catholics in 1641. In case the bias of the pamphleteer was not sufficiently evident, it went on to declare: 'Let us now consider, at least, some of God's Judgments upon the Irish, whereby he hath not left the Innocent blood of His Servants to be altogether unrevenged'. There followed several stories of apparitions:

These bloody Hell-hounds, themselves confessed, That the Ghost of divers of the Protestants, which they had drowned at Portadown Bridge, were daily seen to walk upon the River, sometimes singing of Psalms, sometimes brandishing naked Swords, sometimes shreeking in a most hideous \& fearful manner. So that many of the Popish Irish which dwelt thereabouts, being affrighted therewith were forced to remove their Habitations further off into the Country. ${ }^{34}$

31 The Historical Tragedy, of Young Beateman's Ghost, or The Perjured Maid, Justly Rewarded ([Edinburgh], 1778); William Mann, A Voice from the Dead, Or, The Apparition of William Clarkson (Paisley, 1826), 3, 7.

32 An Account of a Most Horrid and Barbarous Murther and Robbery, Committed on the Body of Captain Brown (Edinburgh, 1694); Shaftsbury's Ghost to Doctor Oats: In a Vision, Concerning the Jesuits and Lords in the Tower (Edinburgh, 1683); The Second Letter, from the Ghost of Bailie Cuthbert ([Edinburgh?], [1780?]); An Account of the Apparition of the Late Lord Kilmarnock (London, 1747).

33 A Dreadful Example for Wicked Husbands: Or the Virtuous Wife in Distress ([Edinburgh?], [1799?]).

34 An Abstract of the Bloody Massacre in Ireland ([Scotland?], [1700?]), 22. 
As we have seen, the idea that those who had died violently and prematurely would return and haunt the place of their death was popular in the medieval period. This pamphlet appropriated the tradition, turning ghosts into tools of God's providential justice. This hybrid between folkloric ghosts and religious moralists was common within the cheap print market. One ghost returned to haunt the faithless lover who had driven her to suicide, but was consoled when he promised to pay for a proper burial for her. ${ }^{35}$ Executed criminals also appeared (Mary MacKinnon included). Robert Johnston, probably the Robert Johnston who was executed for robbery in Edinburgh in 1818, returned as a ghost in a pamphlet to tell other robbers to mend their ways, wailing:

Plung'd in black Darkness and Eternal Night, For Crimes committed 'gainst Almighty Light, For Hell-bred Sins condemned I must be T' endure GOD's Wrath, in endless Misery. ${ }^{36}$

'Hare's dream' depicted William Hare languishing in his prison cell, tormented by the ghosts of those he had killed. One took the form of a groaning skeleton, another a shining angel. His deceased companion Burke also made an appearance, 'chain'd with the murderer's fetter', and counselled him to turn from his evil ways and bewail their sins. Hare concluded:

O silent sleep,-I'll ne'er sleep again, To think on't makes me shiver ;

What tortures and what cruel pain,-Forget it shall I never.

And whether in night's silent hour, Or in the sun shine day, Still will remain at my mind's door, Till I the debt of nature pay. ${ }^{37}$

There was a popular appetite for remorseful criminals: final speeches at the scaffold

35 Captain Mulligan: Miss Bailey's Ghost (Stirling, [1813-20?]).

36 Robert Johnston's Ghost, Or, His Last Advice to the Gipsies, and Other Gangs of Robbers and Murderers in Scotland ([Edinburgh?], [1720?]). On Johnston see, for example, V. A. C. Gatrell, The Hanging Tree: Execution and the English People 1770-1868 (Oxford, 1996), 50.

37 Hare's Dream! Describing the Apparition of Burke and Others, Which Appeared to Him While in the Calton Jail ([Edinburgh], [1829]). 
were a common subject for broadsides. Ghosts were similarly used to demonstrate that crimes were their own punishment, and to appease public outrage over notorious villains.

The same pattern could apply on a smaller scale, with local villains returning as ghosts. The Laird of Coul's Ghost is the best example; as we have seen, the chapbook detailing his story circulated widely and went through many editions. The chapbook about the Provost Abraham Crichton of Sanquhar many not have reached such lofty heights of celebrity, but it was also said to be well known. ${ }^{38}$ According to a summary in the Weekly Magazine in the 1770s, the provost died in 1745, and thereafter was frequently spotted near his own grave, making strange grimaces. Eventually his son and a local minister (Mr Gibson) went to confront him, but the minister lost his nerve and the son met his father alone. The content of their meeting is not recorded, but after it the son removed a partition wall in his house, and sightings of the provost ceased. ${ }^{39}$ Another article published the following month asserted that the minister was actually Mr Hunter, and he did not retreat. ${ }^{40}$ Fuller versions appeared in the second half of the nineteenth century. James Brown declared that Provost Crichton had threatened to destroy a ruined kirk, declaring he would 'sune ding doon the Whigs' sanctuary'. Soon afterwards he fell from his horse and broke his neck. His ghost lingered behind, and upset young girls by grinning at them as they milked their cows. A chain was fixed to his grave to keep him down, without success. Finally the reverend Mr Hunter of Penpont had 'personal dealings' with the ghost, and banished it forever. ${ }^{41}$ Although it was devoid of complicated theological arguments, this story bore notable similarities to that of the Laird of Coul. Both accounts featured a figure in a position of power, disliked by the local community. They were confirmed to be villains when they returned as ghosts. These stories

38 I have not come across any surviving copies of the chap-book, and am relying on William Wilson's 1904 assertion that 'a full account of the wonderful doings of the resuscitated Provost was published in a chap-book, and, circulating over the length and breadth of the land, gave Abraham a notoriety that in life he could not have dreamed of'. William Wilson, Folk Lore and Genealogies of Uppermost Nithsdale (Dumfries, 1904), 33.

39 C. G. to the Weekly Magazine, or Edinburgh Amusement, 16 Apr. 1772, 74.

40 Fabricius to the Weekly Magazine, or Edinburgh Amusement, 7 May 1772, 167-8.

41 James Brown, The History of Sanquhar (Dumfries, 1891), 16. For other versions see Robert Simpson, History of Sanquhar (Edinburgh, 1853), 86-8; Wilson, Folk Lore and Genealogies, 315 . 
carried a moral message, but also a notable element of social subversion: the unscrupulous rich were exposed and punished in the afterlife. This perhaps in part accounts for their success with a popular audience.

Along similar lines, ghosts might be used to shame the villains of contemporary controversies. Shaftsbury's Ghost to Doctor Oats (1683) was a scathing attack on the English perjurer Titus Oates, who falsely claimed to have discovered a Catholic plot to kill Charles II. In the pamphlet Oates was visited from Hell by his recentlydeceased ally the Earl of Shaftesbury. The ghost was described in colourful terms: 'He seem'd like the Emblem of Envy, his Hairs turned into Serpents, his Tap into a Pump, spouting with Sulphur and corroded Poison, with a long Veil of Hypocrisie Ermin'd and Spoted with Blood'. ${ }^{42}$ It was a ridiculous caricature of evil, with the ghost being used to bring drama and humour to a political argument. A ghost was similarly used to comment on a contemporary scandal in The Vision of Dr Morris, or, The Spectral Warning (1821). This broadside reflected on the Cockney Controversy of the early nineteenth century, when hostile reviews of English poets appeared in Blackwood's Magazine. John Scott, an editor who had published many of the poems, died in a duel related to the affair in $1821 .^{43}$ The pamphlet depicted the return of his ghost to Dr Morris, the pseudonym attached to the reviews (generally attributed to John Gibson Lockhart). Morris was termed the 'Scandal-Monger General', and was advised in ominous tones to mend his ways. While the ghost was victim rather than villain in this case, he was still used as a dramatic device: he returned with blood pouring from him, directed his 'lack lustre eye' to his 'cowardly enemy' and addressed him in 'hollow sepuchral tones'. Dramatic ghosts also appeared to make broader political commentary. An Account of a most Horrid, Bloody, and Terrible Apparition, which lately Appeared in the Parish of Shotts ([1793?]) featured the 'hideous spectre' with a 'mangled and torn body' mentioned above. Its arrival was heralded with a noise 'like the rolling of thunder', culminating in a 'loud and awful

42 Shaftsbury's Ghost, 1.

43 See Leonidas M. Jones, 'The Scott-Christie Duel', Texas Studies in Literature and Language, xii (1971), 605-29; Kim Wheatley, 'The Blackwood's Attacks on Leigh Hunt', Nineteenth-Century Literature, xlvii (1992), 1-31; Mark Parker, Literary Magazines and British Romanticism (Cambridge, 2001), 20-7; Richard Cronin, Paper Pellets: British Literary Culture after Waterloo (Oxford, 2010), 1-6. 
yell'. This broadside, like the longer Brissot's Ghost!, was a caution against rebellion: the ghost was a deceased Frenchman who appeared to a group of radicals, preaching on the horrors of the Revolution. ${ }^{44}$

Other works addressed more sentimental themes. In the last quarter of the eighteenth century there was a surge in broadsides featuring tragic poems or ballads with moralising reflections on love. Most were imported from England, where they had been popular in the late seventeenth century. The Kentshire Tragedy told of a ship's captain who killed a man in a fight over a woman, only to be haunted at sea. He confessed his crime to his crew and was thrown overboard when a storm arose. ${ }^{45}$ The Leverpool Tragedy and The Gosford (or Gosport) Tragedy both described sailors who murdered their pregnant lovers, and were haunted by their ghosts. ${ }^{46}$ The Yarmouth Tragedy and Young Grigor's Ghost cautioned cruel parents. Both told of parents who sent their daughter's lover away for being too poor. The lovers died and returned as ghosts, after which the daughters followed them into death, leaving the unhappy parents to repent. ${ }^{47}$ Finally, The Historical Tragedy, of Young Beateman's Ghost (which was unusually in prose rather than verse) presented a woman who broke a promise to her lover and married another man. She was subsequently stolen into death by the vengeful ghost of her forsaken lover, never to be seen again. ${ }^{48}$ While pamphlets such as Brissot's Ghost! reinforced the social order, this type of story could subvert it, albeit subtly. The wealthy were presented as greedy and blind to true worth (similarly to Coul and Crichton); love and honour were exalted above all.

Some pamphlets were chiefly intended to entertain, and their ghosts were humorous or satirical. Thrummy Cap and the Ghaist was a popular chap-book by John Burness, cousin of Robert Burns. It told, in Scots, the story of the brave Thrummy Cap and his cowardly companion lodging in a haunted room. After a few farcical encounters with

44 Brissot's Ghost! Or, Intelligence from the Other World (Edinburgh, 1794).

45 The Kentshire Tragedy, Or, The Constant Lovers Overtbrow ([Edinburgh?], 1794).

46 The Leverpool Tragedy or the Perjur'd Sailor ([Glasgow?], 1767); The Gosford Tragedy: Or the Perjured Carpenter ([Edinburgh?], 1775).

47 The Yarmouth Tragedy: Shewing How by the Cruelty of Their Parents, Two Lovers Were Distroyed ([Edinburgh?], 1775); Young Grigor's Ghost ([Edinburgh?], 1776).

48 Young Beateman's Ghost. 
a ghost who looked exactly like him, Thrummy Cap helped put right a fraud the ghost had committed during his lifetime. ${ }^{49}$ The Ghaist or Gibby and the Ghaist, also told in Scots, similarly explained how a character called Gibby and his dog were forced to stay in a haunted room. They were visited overnight by the ghost of a murderer. The ghost bade Gibby to dig up his victim's bones and see them safely buried in holy ground. He took Gibby to the point where he had buried the bones, but Gibby could see nothing. He resolved to mark the spot by defecating on it and return in the morning. Morning came, and he awakened:

And something fand - no sav'ry - where he lay-The bed was k-d, and the ghaist was flown! ${ }^{50}$

Both Thrummy Cap and Gibby and the Ghaist parodied ghost traditions. Similarly, a broadside called Ghosts, \&c.! began with the preamble that ghosts 'are evidently decreasing in number in these latter times'. It went on to describe how a mob gathered in Edinburgh

to witness a spectre-like figure, arrayed in white, walking about a room in one of the houses. Unlike other ghosts, this one had a shadow, which being reflected upon a wall in the room, had a most dismal effect. The mob were so penetrated with horror that they contemplated the spectre in the profoundest silence, until it extinguished the candle it carried; and they withdrew. ${ }^{51}$

Nothing more supernatural occurred in this story than an intimidating shadow, and the fear of 'the mob' was offered up as the chief talking-point of the piece. The fact that the supposed ghost had a shadow was a hint that the mob might well have been mistaken, as was the candle: flames were supposed to blow out or burn blue in the presence of genuine ghosts.

Other publications went further still. Some pamphlets contained stories of ghost hoaxes as an 'antidote to superstition'. ${ }^{52}$ One printer, George Miller, professed to

49 John Burness, 'Thrummy Cap', Plays, Poems, Tales and Other Pieces (Montrose, 1819). There are numerous pamphlet versions.

50 Robbin Faggot, The Ghaist: A Poem (Glasgow, 1810).

51 Ghosts, \&c! (Edinburgh, 1827).

52 See p. 135. 
regret having published a version of The Laird of Cool's Ghost, considering it immoral (a hint that ghost stories in the cheap press were perceived more as a form of bawdy entertainment than as edifying fables). To atone for it, he printed a work entitled An Antidote to Superstition; or a Cure for Those Weak Minds which are troubled with the Fear of Ghosts, Witches \&c around $1803 .{ }^{53}$ It contained the same article by Philaretes that was printed in the Edinburgh Weekly Magazine, explaining 'the method he took to extricate himself from the fetters of superstition', and associating ghosts with the 'old woman' lurking in our breasts. ${ }^{54}$ It also contained a section on how superstitions made people miserable, declaring: 'For as it is the chief concern of the wise man to retrench the evils of life by the reasonings of philosophy; it is the employment of fools to multiply them by the sentiments of superstition'. ${ }^{55}$ However, works of this sort were greatly outnumbered by those which took a more tolerant view of ghosts.

Overall, the print market revealed - and doubtless promoted - the wide variety of ghost stereotypes in circulation. Ghosts were used as vehicles for religious or political messages. They reflected on contemporary scandals, or on timeless themes such as death. They punished acts of depravity or crimes of love. They also appeared purely for entertainment purposes. In the late seventeenth century the only printed material available on ghosts either dismissed them as demons, or (in the case of Satan's Invisible World Discovered) presented them as religious propagandists. Over the course of the eighteenth century their possible functions expanded rapidly. Oral culture probably remained the chief way in which ghost stories were transmitted, but the development of the print market boosted their potential, such that a figure like the Laird of Coul's ghost could become widely known. Pamphlets and broadsides may have been composed by educated folk, but they were democratising in a sense: they allowed ghost stories to be more easily shared between different social classes, and the stories themselves drew on both folklore and literary culture.

53 Scott A. McLean, 'Cleansing the Hawker's Basket: Popular Literature and the Cheap Periodical Press in Scotland', Studies in Scottish Literature, xxxii (2001), 93-4.

54 See pp. 131-2.

55 An Antidote to Superstition: Or, A Cure for Those Weak Minds Which Are Troubled with the Fear of Ghosts, Witches \&c. (Dunbar, [1803?]), 1, 3, 17-18. 


\section{Folklorists' Accounts}

Lastly we come to folklorists' accounts. Among this body of sources there is plenty of anecdotal evidence for the general popularity of ghost stories. Robert Burns remembered with fondness an old woman who lived with his family, 'remarkable for her ignorance, credulity, and superstition'. She had a great collection of stories and songs about 'devils, ghosts, fairies, brownies, witches, warlocks, spunkies, kelpies, elf-candles, dead-lights, wraiths, apparitions, cantraips, giants, inchanted towers, dragons, and other trumpery'. ${ }^{56}$ John Brand noted that in Britain, "nothing is commoner in Country Places, than for a whole Family in a Winter's Evening, to sit round the Fire, and tell Stories of Apparitions and Ghosts' ${ }^{57}$ One writer described young people telling ghost stories together:

When the lads and lasses for company join'd,

In a crowd round the embers are met,

Talk of fairies, and witches that ride on the wind,

And of ghosts, till they're all in a sweat: ${ }^{58}$

Ghost stories also spread easily within a community. Robert Wodrow often received the same story from several different hands. The fact that some stories existed in different versions (as in the case of Provost Crichton's ghost, or the ghost that visited Archibald Pitcairne) demonstrates that they passed through multiple narrators. ${ }^{59}$ The folklorists' appetite for ghosts may have been inspired by broader cultural trends (namely the romantic movement), but this does not mean that ghost stories were not genuinely popular across different levels of society.

Folklorists' accounts, like cheap print culture, displayed a variety of ghosts. Familiar patterns appeared: ghosts returned to reveal their murderers, to reproach their loved ones for excessive grieving, or to resolve unfinished business. However, unlike other

56 Quoted in Robert Crawford, Scotland's Books (London, 2007), 284.

57 John Brand, Observations on Popular Antiquities (Newcastle, 1777), 102. See also the discussion in E. J. Clery, The Rise of Supernatural Fiction, 1762-1800 (Cambridge, 1995), 2-5.

58 'The Wish: A Song', Weekly Magazine, or Edinburgh Amusement, 24 May 1770, 242; previously appeared as 'Winter', Universal Magazine of Knowledge and Pleasure, Jan. 1770, 43.

59 On Pitcairne see pp. 141-3. 
bodies of sources, folklorists' accounts presented a preponderance of ghosts without specific objectives. The ghosts of well-known villains stalked the streets without feeling the need to offer explicit moral lessons to the living (as they did in pamphlets). Various stories circulated about the ghost of the alleged warlock Major Weir (d. 1670), a staunch Presbyterian who was executed after confessing to various sexual crimes. He was said to wander the Bowhead, argue with an old acquaintance, hold parties in his old house and gallop around on a headless horse. ${ }^{60}$ The lawyer George Mackenzie (1636/1638-1691), reviled for his harsh treatment of Covenanters, was also suspected of post-mortem shenanigans: Robert Chambers recorded how his mausoleum was 'an object of horror to the good people of Edinburgh, as it was almost universally believed that the sprite of the persecutor could get no rest in its superb but gloomy tenement'. ${ }^{61}$ James Kirkton's (c. 1620-99) Secret and True History of the Church of Scotland from the Restoration to the Year 1678 records how James Baillie, Lord Forrester of Corstorphine was stabbed and killed in 1679 by a woman called Christian Hamilton, with whom he had apparently had a romantic altercation. She was convicted of the murder and executed. Kirkton reported that the local village's inhabitants were greatly annoyed by the apparition of a woman who appeared on moonlit nights in the spot where the murder had happened, 'clothed all in white, with a bloody sword in her hand, wandering and wailing, ${ }^{62}$

Those who had died prematurely or in an unfinished state could return even if not villainous. Thomas Pennant recorded a belief that tarans, or the spirits of unbaptised children, haunted areas of woodland, a notion that was also found in the Borders in the early nineteenth century. ${ }^{63}$ The Statistical Account of 1791-9 noted in the entry for the county of Roxburgh that in 'any place where wilful or accidental death has

60 Colin Mackenzie to [the laird of Grant?], 21 July 1720: NRS, GD248/170/3; George Sinclair, Satan's Invisible World Discovered (Edinburgh, 1685), postscript; Robert Chambers, 'Traditions of the Celebrated Major Weir', Edinburgh Literary Journal, 11 Apr. 1829, 307-8.

61 Robert Chambers, Traditions of Edinburgh, revised edn (London, 1868), 245.

62 James Kirkton, The Secret and True History of the Church of Scotland: From the Restoration to the Year 1678, ed. Charles Kirkpatrick Sharpe (Edinburgh, 1817), 182-4.

63 This appeared as an addition to the 1769 tour in Thomas Pennant, A Tour in Scotland 1772, Part 2 (London, 1776), 13. On this belief in the Borders see E., 'Border Sketches No. II', Edinburgh Magazine and Literary Miscellany, Oct. 1817, 237. 
happened, the people [imagine] that such places are haunted by the ghosts of the deceased', giving the poignant example of a woman who died when she fell down a flight of stairs on her wedding day. ${ }^{64}$ A man who drank himself to death in a bet was also said to linger, and Hugh Miller recorded the case of a murdered packman who wandered as a ghost until the hour arrived when he would have died naturally, had he not met with a violent end. ${ }^{65}$

Some popular stories drew on revenant traditions. Scott recorded one story that was 'frequently related by the peasants of Scotland'. A widow, alone with the corpse of her recently deceased husband, accidentally left the door ajar (in defiance of tradition). The corpse sat up and looked at her, 'frowning and grinning at her frightfully'. It did not lie down again until a Catholic priest arrived, put his finger in the corpse's mouth and said the paternoster backwards. It then 'fell back on the bed, and behaved itself as a dead man ought to do'. ${ }^{66}$ Another legend, said to be 'long current' in Glasgow, was recorded by the publisher Robert Chambers. A citizen 'threw the whole town into a state of inexpressible horror and consternation by giving out that, in passing at midnight through the kirk-yard, he saw a neighbour of his own, lately buried, rise out of his grave, and dance a jig with the devil', who played on the bagpipes. The authorities were said to be so horrified they sent the town drummer through the streets the next morning with the purpose of forbidding anyone to whistle, sing or play the 'infernal' tune the Devil had played. ${ }^{67}$ However, revenants were a relative rarity - perhaps surprisingly, since the ghosts of ballads tended to recall revenant beliefs. This was probably in part because romantic fiction had popularised the gliding, white-clad ghost at the expense of the walking corpse. It also reflects different haunting patterns. The dead body could only retain its vitality for a limited period. Revenants tended to make single visits, soon after death, and were then laid again by some means. Equally, purposeful ghosts tended to make one

64 Andrew Bell, 'Parish of Roxburgh', in John Sinclair (ed.), The Statistical Account of Scotland, 1791-1799, electronic edn, 21 vols. (University of Edinburgh, University of Glasgow, 1999), xix, http://stat-acc-scot.edina.ac.uk/link/1791-99/Roxburgh/Roxburgh, accessed 1 Aug. 2015, 136.

65 Robert Chambers, The Picture of Scotland, 2 vols. (Edinburgh, 1827), ii, 338; Hugh Miller, Scenes and Legends of the North of Scotland; Or, The Traditional History of Cromarty, 2nd edn (London, 1850), 360-1.

66 Walter Scott, Minstrelsy of the Scottish Border, 3 vols. (Edinburgh, 1802-3), iii, 252-3.

67 Chambers, Picture of Scotland, i, 377. 
or two visits and rest in peace once their business was concluded. The ballads were an excellent medium through which to record and pass down the details of one-off events like this. Folklorists, however, were more likely to record stories of persistent long-term hauntings. While their more purposeful brethren haunted people, aimless ghosts who wandered indefinitely tended to haunt places, and thus more easily became intertwined with local identity. As we have seen, this appealed to folklorists who were presenting ghosts as a distinctive aspect of Scottish identity. ${ }^{68}$ In addition, persistent hauntings were regularly reinforced within the community memory, and there was an extra frisson of fear in telling a story of a ghost that might still raise its head. Attempts to convert the ghost into a religious messenger were undermined by this natural bias towards the ghost who could never find its peace.

A few ghost stories merit particular consideration because they recur in various sources, and thus seem to have been especially well-known. In a story from Edinburgh, told as early as 1743 and popular in Walter Scott's childhood, a minister was blindfolded and taken at gunpoint to a bedroom. ${ }^{69}$ He saw a beautiful young woman who had recently given birth, and was ordered to pray as he would for someone on the point of death. He objected, pointing out that she had delivered her child safely, but his protests fell on deaf ears. He said the prayers, the blindfold was restored, and he was ushered away. As he left the house he heard a shot. Once he was a good distance from the house he was given a pouch of money and threatened with death should he tell anybody of the adventure. Soon afterwards, the news spread that a house in the Canongate had burned down, killing the young woman who lived there. The minister was too afraid to tell anybody of his experience at the time, but years later he circulated it. Some time after his death a fire broke out where the house had formerly stood. Amidst the flames was seen the apparition of a beautiful woman in nightclothes, some fifty years old, who declared: 'Anes burned, twice burned; the third time I'll scare you all!' In this case the ghost was tied not only to the house in which she had been murdered, but to the particular traumatic circumstances of the fire.

68 See pp. 183-4.

69 From Scott's notes to the fifth canto of 'Rokeby', Walter Scott, Rokeby: A Poem (Edinburgh, 1813), civ-cviii. 
The case of Porteous was another much-discussed story. It was told to Francis Grose in the late 1780 s or 1790 s by a local woman. Slightly different versions were reported in the Statistical Account and by Charles Kirkpatrick Sharpe, and Robert Chambers later wrote a ballad about the story. ${ }^{70}$ The story was set during the reign of Charles II (1660-85), and concerned the tower of Spedlins in Dumfries, owned at the time by Sir Alexander Jardine. A miller called Porteous was suspected of arson, and Jardine imprisoned him in the tower's dungeon. Soon afterwards Jardine was called away to Edinburgh and took the key to the dungeon with him, forgetting about his prisoner. He recollected after a few days and sent back a servant, but Porteous had starved. He had eaten one of his hands - and, according to the version in the Statistical Account, one of his feet as well. He proceeded to haunt the house. Jardine appealed for help. In Grose's version he called for a single minister, in the Statistical Account's he asked for 'a number', and in Sharpe's he summoned a 'whole army'. At the hands of the minister(s), the ghost was confined to the dungeon where he had died, although he could still be heard screaming therein. The minister(s) attached the spell to confine him to a Bible and deposited it in a niche in the wall of the staircase. At one point it was removed to be rebound in Edinburgh, but the ghost then left its cell and caused such trouble that the Bible was hastily restored.

Finally there was the story of Pearlin Jean. ${ }^{71}$ Charles Kirkpatrick Sharpe explained that when he was young, Pearlin Jean was 'the most remarkable ghost in Scotland'. Jean lived in Paris in the late seventeenth century, perhaps as a nun. There she met Robert Stuart, first baron of the Borders estate of Allanbank, and they began a romance. However, he decided to return to Scotland without her. Jean came to him as

70 Francis Grose, The Antiquities of Scotland, 2 vols. (London, 1797), i, 144; Charles Kirkpatrick Sharpe, 'Prefatory Notice', in Charles Kirkpatrick Sharpe (ed.), Memorialls: Or the Memorable Things That Fell out Within This Island of Brittain from 1638 to 1684 (Edinburgh, 1818), lxxxlxxxii; Thomas Marjoribanks, 'Parish of Lochmaben', The New Statistical Account of Scotland, 1834-45, electronic edn, 15 vols. (University of Edinburgh, University of Glasgow, 1999), iv, http://stat-acc-scot.edina.ac.uk/link/1834-45/Dumfries/Lochmaben, accessed 1 Aug. 2015, 385; Robert Chambers, 'The Prisoner of Spedlins', Chambers's Edinburgh Journal, 15 Jan. 1853, 48.

71 Account by Sharpe given in Catherine Crowe, The Night Side of Nature, or Ghosts and Ghost Seers, 2 vols. (London, 1848), ii, 189-92. For a version in verse sent to Sharpe in 1807, see John Marriott, 'Rev John Marriott to C. Kirkpatrick Sharpe, 1807', in Alexander Allardyce (ed.), Letters from and to Charles Kirkpatrick Sharpe, 2 vols. (Edinburgh, 1888), i, 303-6. 
he was stepping into his carriage to depart, and he ordered the postilion to drive on. She fell, and one of the wheels passed over her forehead, killing her. When Stuart drove up to the arched gateway at Allanbank he saw Pearlin Jean sitting on the top of it, head and shoulders covered in blood. Thereafter the house remained haunted for many years. Doors would open and slam shut again in the middle of the night, and noises such as the rustling of silk and pattering of high-heeled shoes were heard in bedrooms and passages. A servant saw the ghost in the orchard at night-time, dressed in large quantities of pearlin lace: this inspired her sobriquet. A group of seven ministers were called in to exorcise Pearlin Jean from the house, but their prayers had no effect. After a few years, the housekeeper tried a different tactic. Robert Stuart had by now married, and his portrait hung on the wall next to that of his wife. The housekeeper had a picture made of Jean, and hung it up in between the images of Robert and his wife. This seemed to pacify the ghost, and although she did not disappear completely, her behaviour became less troublesome. However, at length Robert's wife grew jealous and ordered the portrait to be removed. Thereafter, the ghost became worse-natured than ever. Many years later, long after Robert's death, Jean was still roaming the corridors of Allanbank. An eighteenth-century housekeeper reported seeing her frequently, and claimed she became so used to Jean's noise that it no longer alarmed her. Two ladies, visiting in 1790, had heard nothing of Jean's story, but were disturbed throughout the night by something walking backwards and forwards in their bedchamber.

These three stories combined old and new patterns. The ghosts could not rest because they had died prematurely and unjustly, a common medieval pattern. Jean and Porteous still bore their wounds. None of the ghosts had a specific goal, and they did not appear to specific people, but were tied to the location of their deaths. The stories had moral messages, but religious points were vague at best. Ministers were powerless to contain Pearlin Jean, who could only be pacified through a reunion with her faithless lover. Using bibles to cast spells, as in the Porteous story, was certainly not orthodox Protestant behaviour. The stories were also tinged with romanticism. The settings - an old tower, a manor house, a burning building - had flavours of Gothic. The ghosts themselves were dramatic, poignant figures, innocent victims of 
gross injustices. During their lives they were underdogs, dependent on more powerful figures. They were let down, and their haunting was a form of revenge. As with some ghost pamphlets, there was also an element of social subversion, at least in the case of Jean and Porteous: higher-class figures were punished for mistreating their social inferiors. The woes of love, death and injustice were the primary themes of the stories, rather than theological points about the nature of the afterlife or the wiles of the Devil. Keith Thomas, we can remember, argued that ghosts progressively faded away from the late seventeenth century when they ceased to perform valuable duties for society. ${ }^{72}$ In fact, ghosts continued to be useful, but they did not need to do so in order to survive. It was enough for them to make good stories. The most enduring stories were those that had a strong element of human interest, and that were tied to a particular location (rather than an individual), thus enduring over generations.

\section{The Highlands}

It is worth considering the case of the Highlands separately, because as discussed in the previous chapter, a distinct Highland ghost became popular in the late eighteenth and early nineteenth centuries. As depicted in Ossian and by many of the nineteenthcentury folklorists, the traditional Highland ghost was ancient, warlike, hearty and corporeal. It was similar to the ballad ghost, and also to revenants, but it was not depicted as a corpse risen from the grave, and it tended to appear repeatedly over an extended time-span. It is possible, however, that this ghost was a mere regurgitation of Highland stereotypes, rather than an authentic feature of Highland folklore. In Gaelic literature before Ossian, ghosts rarely appeared. Derick S. Thomson notes that there were many Gaelic songs on supernatural themes, but they were generally concerned with fairies, or occasionally shapeshifting. ${ }^{73}$ There do not seem to have been ghosts of the Ossianic type in Macpherson's Gaelic sources. Thomson notes one case where Macpherson added a ghost to the typically 'unsentimental' Gaelic ballads. He also shows that while Macpherson presented the spirit of Loda as a 'gloomy 72 See p. 2.

73 Derick S. Thomson, An Introduction to Gaelic Poetry, 2nd edn (Edinburgh, 1989), 64. 
ghost', in the source ballads this creature appeared as a 'monstrous hag'. ${ }^{74}$ Macpherson borrowed heavily from Irish material, but warlike ghosts do not seem to have been an ancient Irish tradition either. Phyllis G. Jestice writes that 'Irish ghosts are usually benign', and that in folk culture, most ghost stories are 'postmedieval borrowings from other traditions'. ${ }^{75}$ Peter Womack explains that Macpherson 'derided the spells and wizards he found in Fingalian material from Ireland'. ${ }^{76}$ Just as William Collins decided that ghosts had more dramatic potential than second sight, Macpherson probably judged them a better complement to his romantic vision of Gaelic culture than the supernatural beings that actually appeared in his source material.

Writing in 1899, Alexander MacDonald noted that in the Highlands 'there are far more ghost stories based upon the wraith idea than upon that of the ghost' ${ }^{77}$ This is consistent with the accounts of folklorists prior to the mid-eighteenth century. Martin Martin recorded a good deal on second sight, but very little on ghosts. He did describe people's sightings of 'spirits' in the shape of women, horses, swine, cats and fiery balls, and added that sometimes these spirits made noises and sang Irish songs. One mysterious voice 'resembled the voice of a woman who had died some time before, and the song related to her state in the other world' ${ }^{78}$ Martin also wrote of a rock mass called, in Gaelic, the 'Den of Ghosts', and described a valley that was said to be haunted by spirits termed 'the great men'. All those who entered the valley had to request the protection of the great men, otherwise they would leave the valley insane. ${ }^{79}$ These examples do indicate a belief that the dead could linger, and the 'great men' of the valley have parallels with the ancient, menacing Highland ghosts of the nineteenth-century folklorists. These mentions from Martin are few and far between, however; he certainly does not depict ghost belief as an important facet of Highland culture. Martin also notes the belief in 'the great Giant Fin-Mac-Cowl', the

74 Derick S. Thomson, The Gaelic Sources of Macpherson's Ossian (Edinburgh, 1952), 47, 52.

75 Phyllis G. Jestice, Encyclopedia of Irish Spirituality (Santa Barbara, 2000), 154-5.

76 Peter Womack, Improvement and Romance: Constructing the Myth of the Highlands (Basingstoke, 1988), 98.

77 Alexander MacDonald, 'Highland Ghosts', Transactions of the Gaelic Society of Inverness, xiv (1899), 41.

78 Martin Martin, A Description of the Western Isles of Scotland (London, 1703), 334-5.

79 Ibid., 85-6. 
warrior of Irish mythology whose stories formed the basis for Ossian, but again there is no direct link to ghosts. ${ }^{80}$ Similarly, Robert Kirk focused on second sight and fairies, referencing ghosts only through his explanation that some believed fairies to be the souls of the dead. ${ }^{81}$ Perhaps this was in part because Highland second sight was a relatively fashionable topic, given Robert Boyle's interest. However, Martin did discuss other superstitions, and it seems likely that he would have recorded more on ghost belief had it cropped up. Of course, there also might be geographical variation within the Gàidhealtachd; Martin's picture of the traditions of the western isles cannot necessarily be extended to the Highlands as a whole.

In the early sixteenth-century Flyting of Dumbar and Kennedie, William Dunbar sneeringly referred to Walter Kennedy as a 'hungert heland gaist' (or a starving Highland ghost). He also wrote of how a noble (fictional) knight had

cummered many Helland gaist, Amang thai dully glennis: ${ }^{82}$

While this suggests that there was some notion of Highland ghosts, Dunbar might have used the term for a monster (even a monstrous human). ${ }^{83}$ Even if he were discussing ghosts, he did not draw a clear distinction between Highland and Lowland ghosts, besides in geographical terms. When ghosts from the Highlands were described in texts before Ossian - as, for example, in the trial over the murder of Sergeant Davies - they were not usually ancient warriors. ${ }^{84}$ Instead they followed much the same patterns as Lowland ghosts. John Ramsay of Ochtertyre (1736-1814) was of this opinion, noting that Highland ghost beliefs 'are the same with those of the Lowlanders' ${ }^{85}$

80 Ibid., 152-3, 217, 219, 220.

81 Robert Kirk, 'The Secret Commonwealth of Elves, Fauns \& Fairies', in Michael Hunter (ed.), The Occult Laboratory: Magic, Science, and Second Sight in Late Seventeenth-Century Scotland (Woodbridge, 2001), 83.

82 William Dunbar, 'Schir Johine the Ros, Ane Thing Thair Is Compild (The Flyting of Dumbar and Kennedie)', in Jacqueline Tasioulas (ed.), The Makars: The Poems of Henryson, Dunbar and Douglas (Edinburgh, 1999), v. 21, 1. 167, p. 347; William Dunbar, 'Of Sir Thomas Norray', in David Laing (ed.), The Poems of William Dunbar, 2 vols. (Edinburgh, 1834), i, 1l. 13-14, p. 125.

83 See pp. 7-8.

84 On Sergeant Davies see p. 128.

85 John Ramsay, Scotland and Scotsmen in the Eighteenth Century, ed. Alexander Allardyce, 2 vols. 
Accounts from the late eighteenth and early nineteenth centuries certainly stressed the warlike elements of Highland ghosts. The Statistical Account of 1791-9 declared that in Kirkmichael (in the county of Banff) the belief in the existence of ghosts was very prevalent. It identified the theme of the combative ghost, and combined it with the traditional theme of ghosts seeking retribution, explaining:

On the sequestered hill, and in the darksome valley, frequently does the benighted traveller behold the visionary semblance of his departed friend, perhaps of his enemy. The former addresses him in the language of affection; if danger is approaching, he is warned to prepare against it, or the means of avoiding it disclosed. By the latter, he is attacked with the vehemence of resentment. The inhabitants of this, and the visitant from the other world, engage in furious combat. For a while, the victory is in suspense. At length the ghost is overthrown, and his violence appeased: a few traits of his life upon earth are described. If he stole a ploughshare from his neighbour, the place where it lies concealed is pointed out. His antagonist is requested to restore it to the owner; and if he fails, punishment is threatened to follow the breach of promise; for, till restitution be made, so long must the miserable culprit be excluded from the regions of the happy. ${ }^{86}$

As we have seen, William Grant Stewart and John MacCulloch wrote of corporeal, violent ghosts. Stewart noted that 'it is a common practice with the ghost of the present day to prowl about the country with the laudable intention of committing all the mischief in his power', and added that the ghost is 'perhaps, the best bruiser in the universe'. ${ }^{87}$ Other stories reflected old folkloric themes of powerful corpses. The ghost of a man grabbed his widow's wrist, which was left blue and mortified, and she died in a week. Another breathed on a man and it 'seemed to freeze the blood in his veins'; he died in three days. ${ }^{88}$ Nevertheless, while some folklorists were quick to characterise the 'ancient race' of 'stout, lusty, sociable ghosts', it is worth noting that

(Edinburgh, 1888), ii, 433.

86 John Grant, 'Parish of Kirkmichael', in John Sinclair (ed.), The Statistical Account of Scotland, 1791-1799, electronic edn, 21 vols. (University of Edinburgh, University of Glasgow, 1999), xii, http://stat-acc-scot.edina.ac.uk/link/1791-99/Banff/Kirkmichael, accessed 1 Aug. 2015, 460.

87 William Grant Stewart, The Popular Superstitions and Festive Amusements of the Highlanders of Scotland (Edinburgh, 1823), 19, 20; John MacCulloch, The Highlands and Western Isles of Scotland, 4 vols. (London, 1824), iv, 338.

88 Anne MacVicar Grant, Essays on the Superstitions of the Highlanders of Scotland, 2 vols. (London, 1811), 217-18, 230. 
a reasonably varied set of spectres were recorded. ${ }^{89}$ Some ghosts appeared handsomely attired in Highland dress; others wore shrouds and had hideous, disturbing appearances; others were seen as merely 'numberless dusky and dim-seen forms rising above each other in the air, and muttering indistinct sounds'. ${ }^{90}$ While some ghosts returned to cause mischief, ghosts also came back to condemn excessive grieving, because they had been murdered, to resolve unfinished business, to guard against body-snatching or to help the living. Anne Macvicar Grant actually argued that Highland ghosts 'were generally these conjured up by affection', and appeared 'like "angels sent on errands full of love," to warn or soothe the survivors'. ${ }^{91}$

Specific Highland ghosts who became particularly well known, however, tended to follow more consistent patterns. Many were associated with certain families, a theme of ancestor protection that is relatively uncommon in western ghost stories. MacCulloch explained: 'Every Chief, it is said, had his family spirit; a sort of Herald Mortuary, who forewarned him of death, as it had warned all his predecessors and was to warn his posterity for ever'. ${ }^{22}$ Scott wrote of a female figure called May Moullach (discussed further below, as a figure commonly associated with brownies); she appeared to the Grant family to alert them to oncoming disasters. ${ }^{93}$ There was the Glas Lich, a 'dreadful spectre' said to appear as a 'thin gigantic hag', or a 'tall, emaciated, gigantic female figure'. MacCulloch explained that she was 'the Angel of death to Barrisdale, or to Glengarry; for nobody seems very certain, and not many care'. ${ }^{4}$ In Waverley Scott made use of the Bodach Glas, a grey-clad figure who appeared to foretell death. Robert Chambers explained that this could be traced to a legend in the Maclaine family: an ancestor who had been slain in battle would appear

89 Stewart, Popular Superstitions, 5.

90 Hugh Miller, Scenes and Legends of the North of Scotland, or The Traditional History of Cromarty (Edinburgh, 1835), 369; Stewart, Popular Superstitions, 30; Grant, Essays on the Superstitions, i, 217-18, quotation 255.

91 Grant, Essays on the Superstitions, i, 113. 'Angels sent on errands full of love' is a quotation from Edward Young's 'Night Thoughts'. Edward Young, Edward Young: Night Thoughts, ed. Stephen Cornford (Cambridge, 1989), 1. 293, p. 80.

92 MacCulloch, Highlands and Western Isles, iv, 337. See also Pennant, Tour in Scotland 1772, Part $2,12-13$.

93 Walter Scott, The Lady of the Lake: A Poem (Edinburgh, 1810), Notes to Canto Third, 345.

94 MacCulloch, Highlands and Western Isles, iv, 338; Thomas Pennant, A Tour in Scotland 1772, Part 1 (Chester, 1774), 397; Scott, Lady of the Lake, Notes to Canto Third, 345. 
to the clan chief to notify him if somebody in the family was near death. ${ }^{95}$ This ancestor always appeared on horseback. Both he and the horse were small; in particular, he had a small head, earning him the epithet Hugh of the Little Head. (The Gaelic was 'Eoghan', and in other sources Hugh was given as Ewen.) He appeared at night and would ride furiously around the house, making a noise like the rattling of chains. When observed he would gallop away. Chambers explained that Hugh himself had died according to a prophecy. On the eve of a battle he was told that if his wife voluntarily brought him breakfast the next morning the battle would go well; if he had to call for it he would be killed. His ungenerous wife failed this trial of love, and Hugh met his death as predicted.$^{96}$ A contemporary magazine explained that this spectre's 'mournful duty' was to attend his ancestors at their deathbeds and escort their spirits to the afterlife. ${ }^{97}$ MacCulloch also described a Ewen of the Little Head who inhabited the mountains around Ben More. He was a giant, and lost his head in warfare, but another sprang up in its place. He appeared when a chief of Loch Buy was to die, and rode around the loch for three successive nights. ${ }^{98}$

There were stories of Hugh/Ewen getting into fights with his kinsmen or other locals, but the most violent spectre discussed by the early nineteenth-century folklorists was Lham Dearg, the Ghost of the Bloody Hand. ${ }^{99}$ He was said to haunt the woods of Glenmore and Rothiemurchus, dressed in armour. Scott explained that one of his hands was covered in blood, and he battled everyone he met. Scott presented Lham Dearg as an ancient tradition, explaining that 'the northern champions of old were accustomed peculiarly to search for, and delight in, encounters with such military spectres'. ${ }^{100}$ In Marmion, Scott had the sixteenth-century poet David Lindsay present a story of

95 Robert Chambers, Illustrations of the Author of Waverley: Being Notices and Anecdotes of Real Characters, Scenes, and Incidents, Supposed to Be Described in His Works, 2nd edn (Edinburgh, 1825), 31.

96 Ibid., 31-2; see also 33-4.

97 'Traditions of the Western Highlands, No. III', London Literary Gazette, 20 Mar. 1824, 189.

98 MacCulloch, Highlands and Western Isles, iv, 324-5. See also Scott, Lady of the Lake, Notes to Canto Third, 347.

99 Stories about fights can be found in 'Traditions of the Western Highlands, No. III', 189; Chambers, Illustrations of the Author of Waverley, 33-4.

100 Walter Scott, Marmion: A Tale of Flodden Field (Edinburgh, 1808), Notes to Canto Third, 1xi, 1xiv; Scott, Lady of the Lake, Notes to Canto Third, 345. See also MacCulloch, Highlands and Western Isles, iv, 338. 
A spectre fell, of fiendish might,

In likeness of a Scottish knight, ${ }^{101}$

Scott also wrote of a combative Highland spectre he had seen described in a manuscript from Durham. He estimated that it was about a century old. ${ }^{102}$ Broadly speaking, this body of ghosts was in keeping with the Ossianic template of the Highland ghost. They were ancient and warlike. They also reflected the importance of clan society within the Highlands, remaining tied by kinship bonds long after their deaths. There was certainly a perception among Scott and his contemporaries that they were recording old traditions, and as there is little material on Highland beliefs before this period, the absence of earlier mentions of these ghosts is not sufficient evidence to the contrary. However, even if these ghosts were a feature of Highland folklore long before Macpherson came on to the scene, they do not seem to have been as widely discussed. Insofar as it is possible to speculate based on the limited source material, I would suggest that second sight was the primary way of interpreting and talking about Highland apparitions before the second half of the eighteenth century. Thereafter, ghosts moved into the spotlight. The stout, sturdy, combative ghost may have existed before, but it became significantly more popular, representing a fusion between traditional belief and the romantic vision of Highland society popularised by Macpherson.

It is also interesting to note that ghosts and second sight increasingly overlapped. When ghosts foreshadowed death they were taking on the role of second sight apparitions. Moreover, nineteenth-century folklorists conflated the two beliefs. MacCulloch wrote:

Every Highlander is born with an attached or rather a detached ghost, which accompanies him from the cradle to the grave. ... The Genius, or ghost of our mountaineer, resembles, in every circumstance, even of dress, his principal: infantile at birth, and thus following him through life; undistinguishable from the reality, by those who possess the faculty of seeing the inhabitants of the invisible world; and changing his aspect, and even his dress, in an instant, and in exact

101 Scott, Marmion, canto iv, v. xxii, p. 210.

102 Ibid., Notes to Canto Third, lxii-lxiv. 
conformity to the changes or caprices of the true man. ${ }^{103}$

Similarly, Stewart explained:

Every native Highlander has allied to him, from his birth, one of those airy beings, in the character of an auxiliary or helpmate ... From the birth of the mortal to the eve of his death, the ghost, in point of similitude, is a perfect counterpart or representative of his earthly yoke-fellow ... A short time previous to the mortal's death, and when just on the eve of dissolution, the ghost undergoes a striking revolution in his appearance and habits ... he then becomes the awful emblem of death in all its similitudes. Attired in a shroud, and all the ensigns of the grave, the ghost nocturnally proceeds to the narrow house of his future residence, and there disappears ... The mortal resigns his breath, and is about to follow the course of the dead-candle to his new abode, when Taish na Tialedh, or the funeral foregoing, takes the road. ${ }^{104}$

Stewart clarified that the ghost was 'of course invisible to those not possessing the second-sight'. ${ }^{105} \mathrm{He}$ also noted that these ghosts would perform duties for their earthly counterparts after their deaths: 'In this respect, then, the peculiar advantage of the Highlander over his Lowland neighbour becomes perfectly apparent. Through the medium of a faithful ghost and a confidential friend, transactions, as intricate and ravelled as those of the Laird of Coul, can be easily simplified and assorted.' 106 The ghostly double, the shrouded figure foreshadowing death, and the spectral funeral procession were all themes that appeared frequently in stories of second sight. However, this mode of explaining them, as the mortal's ghost journeying with him throughout life, did not commonly appear in the late seventeenth- and early eighteenth-century investigations into second sight. Martin explained: 'There is a way of foretelling Death by a Cry that they call Taisk, which some call a Wrath in the Low-land', and noted that second sight was called Taish in Irish. ${ }^{107}$ MacCulloch wrote sneeringly: 'If Martin had understood his trade as he ought, he would have known that the Taisch was the Astral spirit of the individual'. ${ }^{108}$ Robert Kirk came somewhat closer to this interpretation:

103 MacCulloch, Highlands and Western Isles, iv, 70.

104 Stewart, Popular Superstitions, 4, 16, 28, 32.

105 Ibid., 17.

106 Ibid., 38.

107 Martin, Description of the Western Isles, 305, 300.

108 MacCulloch, Highlands and Western Isles, iv, 337. 
Some men of that exalted sight (whither by airt or nature) have told me they have seen at those meetings [funeral banquets] a double-man, or the shape of the same man in two places, that is, a Superterranean and a Subterranean Inhabitant perfectly resembling one another in all points, who he notwithstanding could easily distinguish one from another by some secret tockens and operations. ${ }^{109}$

The connection with ghosts had become much clearer and more explicit by the nineteenth century, however. German stories of doppelgängers (or ghostly doubles) had become popular in the latter half of the eighteenth century, perhaps contributing to this interpretation of second sight. ${ }^{110}$ It is possibly also a reflection of the growing importance of ghosts in Scottish culture: there was more general interest in charting their activities, and stories such as the Laird of Coul's came readily to mind as points of comparison. Again, although the evidence is far from conclusive, this may suggest that traditional second sight beliefs were being restyled by romantic folklorists. This phantasmal double was clearly a different category of spectre from the hearty, warlike Highland ghost. However, it was similarly used to underline the idea that the Highlands had their own ancient set of ghost traditions. This may well have been the case, but it was only from the late eighteenth century that it came to be paraded as a point of cultural interest.

\section{Fairies, Brownies, Will o' the Wisps and Banshees}

In his Letters on Demonology and Witchcraft, Walter Scott declared:

[Banshees and brownies] ... are too limited, and too much obliterated from recollection, to call for special discussion ... but something remains to be said upon another species of superstition, so general that it may be called proper to mankind in every climate; so deeply rooted also in human belief, that it is found to survive in states of society during which all other fictions of the same order are entirely dismissed from influence. Mr. Crabbe, with his usual felicity, has called the belief in ghosts 'the last lingering fiction of the brain., ${ }^{111}$

109 Kirk, 'Secret Commonwealth', 80.

110 See Crowe, Night Side of Nature, i, ch. 8.

111 Walter Scott, Letters on Demonology and Witchcraft (London, 1830), letter x, 354. 
Similarly, in the second edition of his Scenes and Legends (1850), Hugh Miller asserted that 'Of all the wilder beliefs of our forefathers, there is none which so truly continues to exist as the belief in the churchyard spectre'. ${ }^{112}$ These assertions, however, did not take into account how closely popular ghost beliefs were intertwined with beliefs about other supernatural beings, nor how unlike the stereotypical 'churchyard spectre' a ghost might be. John MacCulloch complained of the Highlanders:

They have made confusion, in the first place, between the Genius or Astral spirit of the Second Sight, and the true Ghost, or disembodied soul. Some of their Ghosts also are ordinary Elves and Goblins, confounded in the narrations: the Eating Ghost appears to be a corrupted Brownie; and, now and then, I believe he may be traced to the Vampires of Mycone. In other cases, the Ghost is plainly the Fire King, since he carries a light in his mouth; and, occasionally he is even confounded with Fairies and with ordinary Witches. ${ }^{113}$

Let us begin with the case of the fairies. The association between fairies and the dead was long-standing. Fairyland was once linked with Hades, the land of the dead, and the well-known Middle English poem Sir Orfeo showed the dead in fairyland. ${ }^{114}$ As we have seen, Robert Sempill wrote of seeing 'nychtbouris sex or sewin' that the people 'belevit had bene in heawin' riding with the fairies, just as Orfeo saw in fairyland

folk that were thider y-brought And thought dede, and nare nought. ${ }^{115}$

The witch trials offer further sixteenth- and seventeenth-century examples. Elspeth Reoch was visited by a dead kinsman who was also a fairy; Bessie Dunlop's ghostly visitor allowed her to maintain contact with the fairy realm; Andro Man met ghosts at a fairy gathering. Alison Pearson's familiar told her that every year a tithe of the

112 Miller, Scenes and Legends, 2nd edn, 353.

113 MacCulloch, Highlands and Western Isles, iv, 335-6.

114 See Lizanne Henderson and Edward J. Cowan, Scottish Fairy Belief: A History (East Linton, 2001), 19-20; Katharine Mary Briggs, The Anatomy of Puck: An Examination of Fairy Beliefs Among Shakespeare's Contemporaries and Successors (London, 1959), ch. 9.

115 Anne Laskaya and Eve Salisbury (eds.), 'Sir Orfeo', The Middle English Breton Lays, electronic edn (Medieval Institute Publications, 1995), http://d.lib.rochester.edu/teams/publication/laskayaand-salisbury-middle-english-breton-lays, accessed 1 Aug. 2015, 11. 388-9. On Sempill see p. 30. 
fairies were taken away to Hell. As noted above, Robert Kirk explained that some people considered fairies to be spirits of the dead, and thought of 'Fairie-hills' as the dwelling-place of departed souls, or perhaps an intermediary location in which to await the Last Judgement. ${ }^{116}$ James Garden explained to John Aubrey that a Taishtar, or second sighted person, was someone who 'converses with ghosts \& spirits, or as they commonly call them, the fairies or fairie-folk' ${ }^{117}$ Touring Scotland in the 1760s, Thomas Pennant recorded an interesting story from Breadalbane. A man was working in a cabbage garden when he was swept into the air and carried into a field. There he found himself surrounded by a crowd of men and women, some of whom he knew to have been dead for some years. They spoke an unknown language, and their voices had a 'hollow sound'. They pushed him around, but when he said the name of God they all vanished but one. The one who remained made him promise to meet her in a week. He did so, but the spectre said she was in too much of a hurry to speak with him, and bade him leave again, promising that no harm would come to him. ${ }^{118}$ This story recalls old traditions of people being carried away to fairy realms, where groups partied together. Pennant noted that 'the friends and neighbours of the deceased, whom the old dreamer had named, were in the utmost anxiety at finding them in such bad company in the other world'. ${ }^{119}$ The dead had clearly gone somewhere ungodly, yet were not burning in Hell. Fairyland remained a third ground.

'White ladies' were a relatively common category of ghost in nineteenth-century folklore. However, they also had green-clad rivals. The colour green was linked to the natural world; perhaps ironically, this also tied it to the supernatural. When Robert Burns wrote about the apparition of a Scottish muse, he presented her as a beautiful woman in tartan, wearing a green mantle:

Her Mantle large, of greenish hue,

116 Kirk, 'Secret Commonwealth', 83, 85.

117 James Garden, 'Letters from Dr. Ja. Garden, Professor of Theologie at Aberdene to Mr J. Aubrey Concerning the Druid's Temples', in Michael Hunter (ed.), The Occult Laboratory: Magic, Science, and Second Sight in Late Seventeenth-Century Scotland (Woodbridge, 2001), 150.

118 Thomas Pennant, A Tour in Scotland 1769 (Chester, 1771), 89-90.

119 Ibid., 90. 
My gazing wonder chiefly drew;

Deep lights and shades, bold-mingling, threw

A lustre grand;

And seem'd, to my astonish'd view,

A well-known Land. ${ }^{120}$

Fairies and nature spirits were often said to wear green. ${ }^{121}$ Occasionally ghosts imitated this pattern. A mansion in Blairgowrie, Perth, was haunted by a 'green lady'. ${ }^{122}$ The 1834-45 Statistical Account recorded that in Leochel, County of Aberdeen, one area 'has the reputation of being haunted by the apparition of a lady in green or white; but the oldest living inhabitant not having had ocular demonstration, the colour of the dress remains doubtful'. ${ }^{123}$ Writing in 1835, Hugh Miller discussed the Green Lady, terming her 'one of the old Scottish spectres, who flourished before the introduction of shrouds and dead linens' ${ }^{124} \mathrm{He}$ gave several stories of these ladies. They were associated with death; some were explicitly the ghosts of dead people. One was apt to wander among cottages at night, with a goblin child in her arms. She would wash this child in the blood of the house's youngest inhabitant, who would then die. Another was 'Genius of the smallpox'. ${ }^{125}$ In these stories, the green lady displayed characteristics of both ghosts and fairies. Fairies were often malevolent, and were known to play tricks on the households they visited. The mingling of fairy and ghost traditions created a purely folkloric creature, which did not appear in Gothic literature or elite discussions of ghosts.

Then there was the case of brownies, a sub-category of fairies. Brownies served a particular household. They did chores, and occasionally played tricks on the inhabitants. They also might appear in second sight visions. The brownie was associated with the idea of a haunting spirit, and sometimes was depicted as an actual

120 Robert Burns, 'The Vision', Poems, Chiefly in the Scottish Dialect (Kilmarnock, 1786), 90-1.

121 R. L. Tongue, 'Folk-Song and Folklore', Folklore, lxxviii (1967), 298.

122 Robert McDonald, 'Parish of Blairgowrie', The New Statistical Account of Scotland, 1834-45, electronic edn, 15 vols. (University of Edinburgh, University of Glasgow, 1999), x, http://statacc-scot.edina.ac.uk/link/1834-45/Perth/Blairgowrie, accessed 1 Aug. 2015, 915.

123 Alexander Taylor, 'Parish of Leochel and Cushnie', The New Statistical Account of Scotland, 1834-45, electronic edn, 15 vols. (University of Edinburgh, University of Glasgow, 1999), xii, http://stat-acc-scot.edina.ac.uk/link/1834-45/Aberdeen/Leochel, accessed 1 Aug. 2015, 1106.

124 Miller, Scenes and Legends, 128.

125 Ibid., 15. 
individual called Brownie. As we have seen, William Birnie outlined the connections between brownies and the dead in pagan eschatology, explaining that people who had lived good (but not perfect) lives had to spend some time serving mankind as Brunies. ${ }^{126}$ James VI spoke of a spirit called Brownie who 'appeared in time of Papistrie and blindnesse, and haunted divers houses, without doing any evill, but doing as it were necessarie turnes up and down the house'. ${ }^{127}$ John Brand's A Brief Description of Orkney, Zetland, Pightland Firth, and Caithness (1701), claimed that 'Not above 40 or 50 Years ago, almost every Family had a Brouny'. ${ }^{128}$ Martin Martin similarly explained: 'A Spirit by the Countrey People call'd Browny, was frequently seen in all the most Considerable Families in the isles and North of Scotland, in the shape of a tall Man, but within these twenty or thirty years past, he is seen but rarely'. He also recorded a case of the figure Browny helping a man to win at cards. ${ }^{129}$

Brownies were by no means 'obliterated from recollection' by the nineteenth century, as James Hogg's The Brownie of Bodsbeck (1818) indicates. The overlap between brownies and ghosts is neatly demonstrated by two nineteenth-century stories. The Brownie o' Fearnden appeared in a chap-book in $1832 .{ }^{130}$ It described a brownie who served a family faithfully, and saved the goodwife's life by riding out for a midwife when she was in a difficult labour. The Ghaist o' Fearnden (1834) was by Peter Keith, who self-published a few ghost stories. It gave the same account of the family and the difficult labour, but it was a local ghost who rode for the midwife. In both versions the midwife rode with the brownie/ghost and commented on the broadness of his feet. The Ghaist o' Fearnden had an extra component, a passage in which the ghost admitted that he could not rest because he had stolen a pair of gloves during his

126 William Birnie, The Blame of Kirk-Buriall, Tending to Perswade Cemiteriall Civilitie (Edinburgh, 1606, STC 3089), ch. xii. See p. 28.

127 James VI, 'Daemonologie, in Forme of Ane Dialogue', in James Craigie and Alexander Law (eds.), Minor Prose Works of King James VI and I (Edinburgh, 1982), bk. iii, ch. ii, 45.

128 John Brand, A Brief Description of Orkney, Zetland, Pightland-Firth \& Caithness (Edinburgh, 1701), 112.

129 Martin, Description of the Western Isles, 334, 320.

130 Thrummy Cap, a Tale; and The Brownie O' Fearnden, a Ballad (Brechin, 1832). For another version see Alexander Laing, 'The Brownie of Fearnden', in Alexander Whitelaw (ed.), The Book of Scottish Ballads: Collected and Illustrated with Historical and Critical Notices (Glasgow, 1845). 
lifetime, and gained absolution by revealing where he had hidden them. ${ }^{131}$ This reinforced his identity as a returning dead person, but he was nonetheless a ghost who recalled brownie traditions.

In addition to Brownie there was a girl called Meg Mullach (or similar), who cropped up in a variety of different accounts, generally associated with the Highlands. She was usually said to look like a small, hairy creature in the shape of a young girl, with a particularly hairy left hand. Aberdeen professor of theology James Garden explained in the 1690 s that 'Megg Mullach, \& Brownie ... are two ghosts, which (as it is constantly reported) of old haunted a family in Strathspey of the name of Grant' ${ }^{132}$ Meg was usually presented as a female; John MacCulloch described her as the 'female Brownie', and William Grant Stewart suggested that she and Brownie might have been man and wife. ${ }^{133}$ However, she could also take a masculine form, and might even serve as a defender of men's rights. Walter Macfarlane's Geographical Collections, made in the mid-eighteenth century, recorded that the Grant family was haunted by 'a spirit called Meg Mulloch. It appeared like a little Boy, and in dark nights would hold a candle before the Goodman, and shew him the way home, and if the Goodwife would not come to bed, it would cast her in beyond him and if she refused to bring what he desired, it would cast it before him.' ${ }^{134}$ Lachlan Shaw noted that the Tullochgorum family was haunted by 'Maag Moulach, i.e. "One with the left hand all over hairy", and that the synod had made enquiries into her appearances, but discovered little. ${ }^{135}$ In the case of Meg we again see the confusion between ghosts and brownies or fairies. There was no suggestion that Meg was a returning dead person, but she was termed a 'ghost' or described as 'haunting' the families she attended. Both she and Brownie appear to have been well-known, despite not being the kind of ghost that was popularised by Gothic and romantic fiction.

131 Peter Keith, The Ghaist O' Fearnden; Auld Poumire; and Rob Man; Three Tales ([Brechin?], 1834).

132 Garden, 'Letters from Dr. Ja. Garden', 151.

133 MacCulloch, Highlands and Western Isles, iv, 351; Stewart, Popular Superstitions, 142.

134 Walter MacFarlane, Geographical Collections Relating to Scotland Made by Walter Macfarlane, eds. Arthur Mitchell and James Toshach Clark, 3 vols. (Edinburgh, 1906-8), iii, 243.

135 Lachlan Shaw, The History of the Province of Moray (Edinburgh, 1775), 306. See also Pennant, Tour in Scotland 1772, Part 2, 13. 
Ghosts were also tied up with other popular beliefs surrounding death. Will o' the wisps - also known as dead lights, corpse candles or ignis fatuus - were lights that supposedly foreshadowed death. Martin Martin wrote that corpse candles were 'well known and attested', and described spirits appearing as 'fiery balls, which would follow men in the fields'. ${ }^{136}$ Corpse candles were also mentioned by Pennant and by the Reverend John Beaton. ${ }^{137}$ A 1782 text about Buckhaven in Fife, attributed to Dougal Graham, described the local belief in 'willie and the wisp', a fiery devil who led travellers to their death. ${ }^{138}$ In the nineteenth century, the Dumfries and Galloway Monthly Magazine described the appearance of 'deid lichts' to a Dumfries lady in 1822, and Scott explained that the death of a Highland clan chief was 'sometimes supposed to be announced by a chain of lights of different colours'. ${ }^{139}$ William Grant Stewart wrote of how, prior to a mortal's death, his ghostly counterpart would make a journey to his grave, attired in a shroud. He added: 'He is lighted on his way by a pale azure-coloured light of the size of that emitted by a tallow candle, which is of a flickering unsteady nature, sometimes vivid, and sometimes faint, as the mortal inhales and respires his breath'. ${ }^{140}$

In some cases, these lights were linked with actual dead souls. Anne Macvicar Grant told a suggestive story of six bright lights and a 'small greenish one', the souls of seven children (the last born prematurely) who returned to their mother to comfort her nightly. In this case the lights did not foreshadow death, but this was unusual. Grant also wrote of a minister who saw two small lights leaving a part of the churchyard where two children had been buried. They travelled to the nearby hamlet and returned accompanied by a larger light. Soon afterwards their father died. ${ }^{141}$ The

136 Martin, Description of the Western Isles, 313, 334.

137 Pennant, Tour in Scotland 1769, 160; Edward Lhuyd, Edward Lhuyd in the Scottish Highlands, 1699-1700 (Oxford, 1963), 53.

138 Merry Andrew, The Antient and New History of Buck-Haven in Fife Shire ([Edinburgh?], 1782), 22.

139 J. Maxwell Wood, Witchcraft and Superstitious Record in Southwest Scotland (Dumfries, 1911), 213; Scott, Lady of the Lake, Notes to Canto Third, 346-7.

140 Stewart, Popular Superstitions, 28. See also MacCulloch, Highlands and Western Isles, iv, 359; Jean Matthias D'Amour, Memoirs of Mr. Matthias d'Amour, ed. Paul Rodgers (London, 1836), 136; R. C. Maclagan, 'Ghost Lights of the West Highlands', Folklore, viii (1897), 203-56.

141 Grant, Essays on the Superstitions, i, 190-5, 258-61. See also 290. 
1834 Statistical Account recorded that in Inverness, the 'luminous meteor' called Will o' the Wisp was seen every year since 1812. It was linked to a story of a woman who went at night to sand-banks to dig for some rue (Galium verum), a substance used as red dye. She went against her husband's will and in defiance of a prohibition by the local magistrates (the sand-banks, once excavated, were easily blown away). She never returned, and her body was never found. Shortly afterwards the meteor was first seen, giving rise to the theory that it was the ghost of 'the unfortunate and profane woman'. ${ }^{142}$

Certain noises also foreshadowed death. The crowing of a cock was a common example, and in the poems of Ossian death could be heard on a harp. ${ }^{143}$ Howling noises were also reported. ${ }^{144}$ This recalled ideas about banshees, a feature of medieval folklore across Europe. Banshees screeched or wailed before death. They seem to have survived as a belief in Scotland. Pennant noted that 'in certain places, the death of people is supposed to be foretold by the cries and shrieks of Benshi', and although Scott claimed that banshees were largely 'obliterated from recollection' alongside brownies, he also wrote that 'the Ben-Shie implies the female Fairy, whose lamentations were often supposed to precede the death of a chieftain of particular families'. ${ }^{145}$ Banshees too might be intertwined with ghosts. James Macpherson declared that 'It was long the opinion of the ancient Scots, that a ghost was heard shrieking near the place where a death was to happen soon after', and added that the ghost would come 'mounted on a meteor', incorporating the idea of dead lights. ${ }^{146}$ The Statistical Account of 1791-99 recorded that in Applecross, in the county of Ross and Cromarty, 'The ghost of the dying, called tasks, are said to be heard, their

142 Roderick MacLean, 'Parish of South Uist', The New Statistical Account of Scotland, 1834-45, electronic edn, 15 vols. (University of Edinburgh, University of Glasgow, 1999), xiv, http://statacc-scot.edina.ac.uk/link/1834-45/Inverness/South\%20Uist, accessed 1 Aug. 2015, 184.

143 Lhuyd, Edward Lhuyd in the Scottish Highlands, 55.

144 Theophilus Insulanus, A Treatise on the Second Sight, Dreams and Apparitions (Edinburgh, 1763), 76, 113.

145 Pennant, Tour in Scotland 1769, 160; Scott, Lady of the Lake, Notes to Canto Third, 346. Scott also explained that domestic spirits such as Meg Mullach informed their families of approaching disaster by wailing. Ibid., 345. See also Scott's introduction to the Magnum Opus edition of The Monastery. Scott, Waverley Novels, Vol. 18: The Monastery (Edinburgh, 1830), xv.

146 James Macpherson, 'Fingal, an Ancient Epic Poem', The Works of Ossian, the Son of Fingal, 2 vols. (London, 1765), i, bk. i, 28. 
cry being a repetition of the moans of the sick'. ${ }^{147}$ Speaking of the Highlands, John Graham Dalyell noted: 'The ghosts of the dying are spoke of as in a separate state; and others were believed, not only to echo the moans of the sick, preceding dissolution, but after it to prove an audible guide to the place of sepulture'. ${ }^{148}$

These stories indicate how flexible and varied popular ghost beliefs could be. The notion of a 'ghost' was not strictly defined: it could be tied to a fairy, a brownie, an apparition before death, even a strange light or noise. On the one hand, this suggests that ghosts were a very familiar concept. On the other hand, it stands as evidence that on the popular level, ghost beliefs could not really survive in isolation: they were inextricably linked to the brownies and banshees dismissed by Scott, alongside a host of other supernatural beings. Gothicism and romanticism produced a more distinctive ghost stereotype, which was dominant within literary accounts of ghosts, and would increasingly shape popular perceptions of ghosts in decades to come. However, by the early nineteenth century this process was still in its infancy. Popular ghosts remained diverse and entangled with other folkloric creatures.

\section{Belief}

The fact that ghost stories were in circulation does not necessarily mean that people took them seriously. As we saw in the last chapter, there was a perception that ghost stories were valuable cultural relics regardless of whether or not folk actually believed in them. Unfortunately, there are few other ways to gauge levels of early modern belief. Educated men might complain about how ghost belief terrorised the 'unlearned', but they were not in the habit of conducting methodical surveys of belief. ${ }^{149}$ Admittedly, when folklorists recorded stories it was often with the

147 John McQueen, 'Parish of Applecross', in John Sinclair (ed.), The Statistical Account of Scotland, 1791-1799, electronic edn, 21 vols. (University of Edinburgh, University of Glasgow, 1999), iii， http://stat-acc-scot.edina.ac.uk/link/1791-99/Ross\%20and\%20Cromarty/ Applecross, accessed 1 Aug. 2015, 380.

148 John Graham Dalyell, The Darker Superstitions of Scotland: Illustrated from History and Practice (Edinburgh, 1834), 589.

149 Insulanus, Treatise on the Second Sight, 112. 
understanding - whether or not it was explicitly stated - that they were believed locally. Wodrow would often specify that his stories were generally believed, and when Francis Grose recorded the story of Porteous he noted that the woman who informed him seemed to believe 'every syllable'. ${ }^{150}$ However, several folklorists rejected the idea of the credulous populace. Records from the Statistical Acccounts of 1791-9 and 1834-5 hailed the demise of superstition, with one asserting that 'ghosts, gobblins, witches, and fairies have relinquished the land'. ${ }^{151}$ Robert Chambers declared that in the late eighteenth century 'the shades of superstition began universally to give way in Scotland'. ${ }^{152}$ Writing in the 1790s, Elizabeth Mure similarly consigned credulity to the realms of the past:

The fear of Hell and deceitful power of the Devil was at the bottom of all [the Scots'] religious sentiments. The established belief in witchcraft (for which many suffer'd) prevailed much at this time; Ghosts too and appearitions of various kinds were credit'd; few old houses was without a Ghost chamber that few people had Courage to sleep in. Omens and Dreams were much regarded even by people of the best Education. These were the manners of the last Century, and remained in part for 30 years in this. ${ }^{153}$

Hugh Miller even allowed for scepticism on the part of the man who told him ghost stories, explaining: 'He had, I suspect, a good deal of the skeptic in his composition, and regarded his ghost stories rather as the machinery of a sort of domestic poetry than as pieces of real history'. ${ }^{154}$

150 Grose, Antiquities of Scotland, i, 144.

151 See, for example, John Tod, 'Parish of Mauchline', The New Statistical Account of Scotland, 1834-45, electronic edn, 15 vols. (University of Edinburgh, University of Glasgow, 1999), v, http://stat-acc-scot.edina.ac.uk/link/1834-45/Ayrshire/Mauchline, 167; A. Johnstone, 'Parish of Monquhitter: Additional Communications', in John Sinclair (ed.), The Statistical Account of Scotland, 1791-1799, electronic edn, 21 vols. (University of Edinburgh, University of Glasgow, 1999), xxi, http://stat-acc-scot.edina.ac.uk/link/1791-99/General\%20Appendixgen\%20App\%20 Vol6/21/138, 149. Quotation from William McRitchie, 'Parish of Clunie', in John Sinclair (ed.), The Statistical Account of Scotland, 1791-1799, electronic edn, 21 vols. (University of Edinburgh, University of Glasgow, 1999), ix, http://stat-acc-scot.edina.ac.uk/link/179199/Perth/Clunie, 253. All accessed 1 Aug. 2015.

152 Chambers, 'Traditions of the Celebrated Major Weir', 307.

153 Elizabeth Mure, 'Some Remarks on the Change of Manners in My Own Time, 1700-1790', in William Mure (ed.), Selections from the Family Papers Preserved at Caldwell, 3 vols. (Glasgow, 1854), i, 266.

154 Miller, Scenes and Legends, 2nd edn, 328-9. 
After touring Scotland in 1773, Samuel Johnson concluded that second sight belief had survived in the islands, although it was rejected by Lowlanders and ministers:

It is the common talk of the Lowland Scots, that the notion of the Second Sight is wearing away with other superstitions; and that its reality is no longer supposed, but by the grossest people. How far its prevalence ever extended, or what ground it has lost, I know not. The Islanders of all degrees, whether of rank or understanding, universally admit it, except the Ministers, who universally deny it, and are suspected to deny it, in consequence of a system, against conviction. ${ }^{155}$

A discussion of Shetland from the 1834-5 Statistical Accounts declared that 'Witchcraft, charms, and apparitions, are firmly believed in', while the entry on Kilbride, Bute, similarly attested that 'the belief in ghosts, witches, and fairies, has still a firm hold of the minds of many'. ${ }^{156}$ However, writing in 1824, MacCulloch presented the Highlanders as no more credulous on any topic than the Lowlanders. He noted that 'the real Ghosts or disembodied spirits of men, seem to have fled with the Second sight', adding that Macpherson probably borrowed his, perhaps from Norwegian mythology. He explained that Highlanders remembered ghosts because of their poetry, not because they featured in their belief system any more. He excepted only a few 'weak and credulous' people influenced by the dramatic landscape. ${ }^{157} \mathrm{He}$ also declared:

All the world has heard of Highland Ghosts and Superstitions, and we have been desired to believe that the people are as credulous as ever. This has been the consequence of repeating, as of to-day, things long past: it is, as I have often said, Romance attempting to pass for Truth. The Highlanders now believe just as much as their Pictish and Saxon neighbours. ${ }^{158}$

David Stewart of Garth similarly asserted that missionary work had caused people to

155 Samuel Johnson, A Journey to the Western Islands of Scotland (London, 1775), 252.

156 Laurence Edmondaton, 'General Observations on the County of Shetland', The New Statistical Account of Scotland, 1834-45, electronic edn, 15 vols. (University of Edinburgh, University of Glasgow, 1999), xv, http://stat-acc-scot.edina.ac.uk/link/1834-45/Shetland/General\%20 Observations, 157; Allan McNaughton, 'Parish of Kilbride', The New Statistical Account of Scotland, 1834-45, electronic edn, 15 vols. (University of Edinburgh, University of Glasgow, 1999), v, http://stat-acc-scot.edina.ac.uk/link/1834-45/Bute/Kilbride, 27. Both accessed 1 Aug. 2015.

157 MacCulloch, Highlands and Western Isles, iv, 340-1.

158 Ibid., 320. 
lose 'a great portion of their belief in fairies, ghosts and the second sight'. Interestingly, he regretted the loss of these 'innocent, attractive and often sublime superstitions' which acted as a moral safeguard, adding 'the fear of a ghost is as honourable and legitimate a check as the fear of the gallows'. ${ }^{159}$

In short, it is impossible to judge how widespread ghost belief was across the Scottish population. Just as in elite culture, there is evidence that there were folk who believed in ghosts and folk who did not. The development of print culture did make ghost stories accessible in a new format, however, and the fresh interest of folklorists may also have contributed to the circulation of ghost stories. As in the previous chapter, the overall conclusion must be that even if they were not always taken to be objective realities, ghosts had value within Scottish society. This might stem from their religious messages, their reflections on death and social injustice, their historical significance or simply the fact that they made good stories.

\section{Conclusion}

The ghosts of popular culture followed a variety of patterns. Revenants survived (particularly through the ballads), but the ethereal ghost also appeared, as did more or less everything in between. Ghosts were further diversified through being interwoven with beliefs about fairies, brownies, even strange lights and noises. Following on from the last chapter, it is natural to ask whether the romantic Scottish ghost was authentic, or created by writers who wished to export a certain image of Scotland. The (perhaps inevitable) answer is that it was probably a bit of both. Heavily romanticised ghosts do seem to have appeared with more frequency as the eighteenth century progressed. As we have seen in the last chapter, these ghosts were characterised by a focus on aesthetics. They were presented in dramatic terms, and were often tragic, sometimes majestic. They might be of the white, gliding, occasionally resplendent variety; alternatively they might be hearty, corporeal

159 David Stewart, Sketches of the Character, Manners, and Present State of the Highlanders of Scotland, 2 vols. (Edinburgh, 1822), i, 129. 
Highland spectres. They liked to haunt old castles and churchyards. While these ghosts owed much to literary trends, it is difficult to state that elite culture was simply imposing its own template on a divergent popular tradition. The white ghost was of long standing, and the idea that a ghost might haunt the place of its death, or the place where its body lay, was also not new. Incorporeality was a feature that could be traced to second sight or wraith apparitions, as well as to certain medieval depictions, as much as to Gothic poetry. The Highland ghost, while clearly in part inspired by stereotypes of the Highlanders and the poems of Ossian, also incorporated elements of folk belief such as revenant traditions, giants and second sight apparitions. Popular ghosts, in short, were a diverse bunch. By emphasising certain types of ghost at the expense of others, folklorists and fiction writers may have caused certain traditions to attain a new dominance, but that is not to say that they created those traditions from scratch.

Despite the variety of popular ghosts, a few themes emerge with particular frequency. Ghosts were generally an aberration. They tended to signify that an established religious process had been violated - that process being the journey from death to the afterlife, and the grieving and burial practices surrounding it. Perhaps the death had been premature and/or violent; perhaps the living were mourning it too much; perhaps the ghost had left unfinished business. Stories of positive ghosts returning by divine permission to pass on messages about the afterlife were (unsurprisingly) much less common outside of evangelising texts. Ghosts did carry broad Christian messages, but they also represented a certain discomfort with the kirk's clean separation between the living and the dead; when ghosts returned to reproach their loved ones for grieving they were supplanting the kirk as providers of pastoral care. The prominent Highland theme of ghosts appearing to their descendants to forewarn them of oncoming deaths and escort the dead to the afterlife also fitted this pattern. Death was the domain of the ghost, and it was the ghost (rather than proper religious convictions) that secured safe passage to the world beyond. Ghosts also supplemented early modern judicial systems, revealing crimes or demonstrating that villains were thoroughly punished. They became a means of managing injustice, and some of the most popular stories of the period incorporated an element of social 
subversion; powerful figures were punished for mistreating their dependants. Ghosts survived in part because they patched up deficiencies in early modern systems of community support. The themes of death and social injustice also made for powerful and emotive stories, stories that were easily remembered and retold.

Ghosts often came to feed into community identity. They did this in part through tackling deviancy. The moralising nature of the stories meant that certain codes of behaviour were passed down over generations. A widow(er) grieving too heavily, or a lawyer behaving dishonestly, was not a private affair. It had the potential to affect the whole neighbourhood through causing a supernatural intrusion, and was condemned by the collective voices of the past. In this sense, ghosts were defenders of tradition. Although ghostly visitations could be framed as punishments, however, they could also be objects of pride. The ghosts who haunted Highland families were often presented as a distinction, despite the fact that they were usually harbingers of misfortune. Unlike most of the ghosts in ballads and pamphlets, ghosts recorded by folklorists often made frequent reappearances in the same place and over a long period of time. These stories were reinforced by repeated sightings over the generations, and the ghosts became a local point of interest. While this was not necessarily a new pattern in the eighteenth century, it probably did become more widespread. As ghosts were gradually disassociated from demons they became better able to serve as community (or family) mascots. The expansion of print culture and the development of folklore as a discipline also meant that stories were better preserved and better able to travel across the country. Whether or not this resulted in more people actually believing in ghosts is impossible to judge. Nonetheless, ghosts had an important place within Scottish folk culture. If some aspects of the Scottish Enlightenment threatened to undermine their importance, other developments in the period reinforced it. 


\section{Conclusion}

The study of ghosts can be approached in various ways. On one hand, there is something universal and timeless in the idea of the dead lingering on. There is a history to be written that traces ghostly manifestations across different cultures and time periods, emphasising the strands of continuity. In this reading, ghosts reflect on what it is to be human. On the other hand, changes in ghost belief also tell a story, a story about being human within a particular culture or at a particular point in time. The development of ghosts in Enlightenment Scotland is one small facet of this story. Scotland had long been seen as a wild and magical place, but it was over the course of the long eighteenth century that the country's haunted reputation was crystallised, and ghosts ascended to a new cultural prominence. There is an irony in this, given that the Enlightenment is often seen as an important stepping stone in the disenchantment of the world. It is certainly true that ghosts (and other supernatural beings) were re-evaluated in the light of the medical and philosophical developments of the period, but it does not follow that they were exorcised from Scottish society. Accounts of ghosts proliferated, and they came to reflect on an increasingly wide range of contemporary concerns.

Before discussing how this evolution affects our understanding of the period, it is worth briefly summarising the course it took. Ghosts had an ambiguous place in Scottish medieval culture. Some writers suggested that God might allow departed souls to return, but apparitions could also be interpreted as demons. After the Reformation and the demonological writing of James VI, the orthodox position became clearer. The dead could not come back. Apparitions were deceptions, whether conceived by drunkenness, melancholy or the wiles of the Devil. Most writers adopted this viewpoint. Ghost stories did remain in circulation, however. Ideas of the lingering power of the dead survived in popular culture, reinforced in part by the witch trials. Kirk session reports suggest occasional uncertainty over the correct interpretation of ghosts, and the Wars of the Three Kingdoms combined with the Covenanters' interest in special providences meant that accounts of strange 
apparitions circulated more widely from the 1640s. Nevertheless, this was a period when ghosts were sidelined, and respectable ministers and theologians had little interest in discussing them. It is only with the work of George Sinclair and Robert Wodrow in the late seventeenth and early eighteenth centuries that we see a serious attempt to reinstate ghosts into the Protestant world-view. The approach never became mainstream, but it established a new template for ghosts. There were continued attempts to employ them as religious propagandists throughout the eighteenth century, whether in support of basic Christian tenets, or specific theological arguments such as an intermediate state.

Relatively few ghost stories emerged from about the 1730s to the end of the $1760 \mathrm{~s}$. Wodrow and Sinclair had no real successors as collators of stories until the nineteenth century (unless one counts Theophilus Insulanus, who did include a couple of ghost stories in his collection on second sight). This period did, however, see court cases concerning ghosts, as well as some discussion about the psychological and physiological causes of ghost seeing. It also saw the publication of the story of the Laird of Coul's ghost, the emergence of graveyard poetry and the 'discovery' of the poems of Ossian. Thereafter, the late eighteenth and early nineteenth centuries were witness to a rapid expansion of printed ghost stories and discussion on ghosts. Periodicals opened up a new venue for debate, and there was a growth in scientific treatises dealing with apparitions. Gothic and romantic literature developed, theatre became more widespread and a new antiquarian movement was born. Ghosts' functions broadened significantly. They could be humorous or satirical figures; they could be used to explore new conceptions of mental disorders, or visions of death; they could offer political, religious or moral commentary; they could be picturesque, atmospheric devices; they could be displayed as a facet of local or national identity. Ghosts also evolved aesthetically, with more romanticised archetypes becoming popular. There was no clear consensus about how a ghost should look, behave or be interpreted, which meant that stories could be adapted to serve a variety of purposes.

These changes primarily took place in elite culture. The patterns of story-telling in 
folk culture probably did not undergo the same transformation. Isolated local communities were not as susceptible to changes in fashion, print culture was less accessible to the illiterate, and oral culture tended to preserve old traditions. The ghosts of ballads and folk stories were more consistent in their messages. They usually offered emotional succour in the face of death and injustice, and condemned behaviour that violated social norms. Nevertheless, there was inevitably some crossover between popular and elite. Popular stories recorded in the nineteenth century employed gothic motifs, while the stereotype of the corporeal Highland ghost drew on both folklore and elite conceptions of the region. Folklorists increasingly recorded cases of ghosts haunting specific places - churchyards, manor houses, local communities - as opposed to the pattern seen (for example) in the ballads, of ghosts returning to people. This in part reflects the agenda of the folklorists, but it may also show the influence of gothicism and romanticism, which associated ghosts with sinister or picturesque landscapes. The expansion of cheap print culture allowed a more diverse range of ghosts to circulate at all levels of society.

Many factors contributed to the growing diversity of ghosts. The Scientific Revolution and the Enlightenment encouraged efforts to explore the natural world and explain it in terms beyond the purely theological. The development of the publishing industry and improved literacy rates allowed more ideas about ghosts to circulate; the emergence of new genres also promoted diversity. Increased interest in geographical exploration and recording local customs was another factor, as was political change. Loss of governmental autonomy with the 1707 Union, the decline of Highland power after the failure of Jacobitism, and the social changes wrought by urbanisation prompted writers to use ghosts to reflect on Scotland's past, present and future. Perhaps the single most important reason for the diversification of ghosts, however, was the kirk's gradual loss of control over them. While the ghost by no means became a fully secularised figure, secularised visions of ghosts appeared in elite culture. It is worth exploring this pattern further, as it feeds into the prominent historiographical debate about the disenchantment of Western society. 
In the decades after the Reformation, ghosts were presented as a hallmark of Catholicism, despite the fact that Catholic views on ghosts were variable. James VI's 1597 Daemonologie emerged from a culture in which the delineation between Protestant and Catholic was of primary importance. His argument that ghosts were actually demons was in part an attack on Catholic theology. As the decades went by and the threat of counter-Reformation receded, the battle lines changed. For those Presbyterians who lost their livelihoods after the 1660 Restoration, the first priority was to demonstrate that God was on their side. While few would endorse the idea of the returning dead, apparitions were presented more favourably: there was an emphasis on divine signs rather than diabolic tricks. By the late seventeenth century, talk of a new enemy had become fashionable. The Catholic threat had by no means become insignificant; the Catholic James VII took the throne in 1685. Presbyterians were also keen to avoid accusations of enthusiasm, which resulted in increased theological rigidity in some areas. ${ }^{1}$ Nevertheless, Sinclair, Wodrow and some of Wodrow's correspondents were more concerned with combating apathy and the spread of potentially atheistic philosophies than upholding a strictly orthodox theological framework. In this we can see the early seeds of a pattern that developed in the second half of the eighteenth century, as Moderatism came to dominate the kirk. Precise theological differences between different Christian sects declined in importance, with the big debates focusing instead on core elements of Christianity.

While Wodrow and Sinclair's theological flexibility may have anticipated later developments, their use of witches, demons and ghosts swiftly became oldfashioned. Miracles and divine providence remained important elements of religious thinking, but witchcraft and demonology became relatively uncomfortable subjects after the decriminalisation of witcheraft in 1736. In the case of ghosts, psychological and physiological explanations became more popular (at least in print) than depictions of ghosts as either divine messengers or demons. This meant, however, that there was freedom for ghosts to develop outside of the Christian framework. The kirk may not have been comfortable with the way in which ghosts were presented in

1 To borrow Alasdair Raffe's phrase, given in 'Presbyterianism, Secularization, and Scottish Politics after the Revolution of 1688-1690’, Historical Journal, liii (2010), 335. 
literature (as is suggested by Blair's 'The Grave'), nor with the rise of theatre, but it had lost (to some degree relinquished) its monopoly on representations of the supernatural. To take one example, the ghosts that made it into print from the Reformation to the eighteenth century usually made broadly orthodox points about death and the afterlife. There were exceptions - wraith stories in particular presented a poignant vision of death - but in general ghosts upheld a Christian vision, discussing the joys of Heaven and the terrors of Hell, or demonstrating the power of God's providential justice. This changed in the second half of the eighteenth century. Death was presented as mysterious, frightening and tragic. There was less focus on the afterlife, and more on the melancholy aspects of leaving behind one's earthly life. The secularisation narrative has been over-emphasised with respect to the eighteenth century, and recent scholarship has tended instead to demonstrate how religion remained central to the lives of the Scottish people. ${ }^{2}$ While there may not have been a general process of secularisation, however, there was a gradual secularisation of magic.

For Max Weber, disentangling magical beliefs and practices from orthodox religion was an important element of the process of disenchantment. Writing in 1904-5, Weber argued that the Reformation was a crucial milestone, as it encouraged the 'rationalization of the world' by downplaying the importance of sacramental magic as a means of attaining salvation. ${ }^{3}$ Robert Scribner has outlined the flaws in this argument, showing that magical beliefs and practices remained central to religious experience in Protestant countries. ${ }^{4}$ The beginning of the separation of religion and magic can, however, be relocated in the eighteenth century. It was a patchy process in the case of ghosts, there remained educated men and women ready to defend ghosts on religious grounds throughout the century - but a significant one

2 See Callum G. Brown, Religion and Society in Scotland since 1707 (Edinburgh, 1997), 8-11; Roger L. Emerson, 'The Religious, the Secular and the Worldly: Scotland 1680-1800', in James E. Crimmins (ed.), Religion, Secularization and Political Thought: Thomas Hobbes to J. S. Mill (London, 1989); Raffe, 'Presbyterianism.'

3 Max Weber, The Protestant Ethic and the Spirit of Capitalism, trans. Talcott Parsons, electronic edn (Routledge, 2005), http://www.tandfebooks.com/action/showBook?doi=10.4324/97802039 95808, accessed 1 Aug. 2015, 71.

4 Robert W. Scribner, 'The Reformation, Popular Magic, and the "Disenchantment of the World", Journal of Interdisciplinary History, xxiii (1993), 475-94. 
nonetheless. Of course, for Weber, disenchantment was more than just the uncoupling of magic and religion. It was a process of progressive intellectualisation and rationalisation. Weber clarified that this did not mean 'an increased and general knowledge of the conditions under which one lives'. Instead it signified 'the knowledge or belief that if one but wished one could learn it at any time'. Weber continued: 'Hence, it means that principally there are no mysterious incalculable forces that come into play, but rather that one can, in principle, master all things by calculation. This means that the world is disenchanted. One need no longer have recourse to magical means in order to master or implore the spirits. ${ }^{5}$ There may have been more ghost stories in circulation in the eighteenth century, but for Weber this would be less important than the question of how ghosts were interpreted. The fact that ghosts were increasingly explained away in natural terms, rather than as demons, is a sign of disenchantment by Weber's definition. Weber's model of rationalisation therefore has some merit in explaining the changes of the eighteenth century. However, this was only one of several different strands of development. We should be wary of exaggerating the impact of changes in science, philosophy and theology on daily experience.

Several historians have posited that the supernatural migrated into the sphere of art, literature and imagination in the eighteenth century. As Alexandra Walsham summarises, 'magic and the supernatural were becoming absorbed into a culture of commodified amusement and transformed into objects of aesthetic pleasure and fascination'. ${ }^{6}$ We can certainly see this pattern in eighteenth- and early nineteenthcentury Scotland. Ghosts had occasionally appeared in poems and humorous pamphlets before the eighteenth century, but the expansion of print and the development of theatre and new forms of literature gave the ghost a much more secure place within the world of entertainment. Historians often set aside the realm of literature, implying that as ghosts shifted into this domain they ceased to be taken as objective realities, and thus lost much of their power and influence. However,

5 Max Weber, 'Science as a Vocation', in H. H. Gerth and C. Wright Mills (eds.), From Max Weber: Essays in Sociology (New York, 1946), 139.

6 Alexandra Walsham, 'The Reformation and "The Disenchantment of the World" Reassessed', Historical Journal, li (2008), 519. 
contemporaries often presented the question of belief as irrelevant. Ghosts, it was argued, had a strong grasp on the imagination regardless of whether or not they were real, or thought to be so. The ghosts of gothic literature could be horrifying as representatives of death and madness even when they were explained away.

Even if we do attach importance to belief, there is no conclusive evidence for decline over the course of the long eighteenth century. On the popular level, there is anecdotal evidence of both scepticism and credulity, but the wider circulation of stories probably reinforced long-standing ghost beliefs even as other cultural developments threatened them. Within educated culture it became usual to explain ghosts away in natural terms, but there were nonetheless continued attempts to defend their reality throughout the century. It has also been suggested that belief in the supernatural did not disappear, but retreated from the public to the private sphere. $^{7}$ Gentlemen of fashion might openly declare themselves sceptics, but inwardly be rather less convinced (as has been argued in the case of Walter Scott). ${ }^{8}$ Having examined the Royal Society's reluctance to engage publicly with the occult, Michael Hunter suggests that the late seventeenth century was witness, not to the 'decline of magic', but rather to the 'rise of schizophrenia'. ${ }^{9}$ It is worth remembering that belief can operate on different levels. The boundaries of fact and fiction were fluid, and the rise of gothic and romantic literature encouraged a perception that wild, lonely places were haunted with Weber's 'mysterious, incalculable forces'. Several authors noted that even the most convinced sceptic felt a shiver when walking through a dark churchyard. It was possible to have an instinctual, involuntary belief in ghosts despite not crediting them on an intellectual level. As we have seen, one writer argued that he had chosen to believe in ghosts so that he could truly appreciate horror stories. ${ }^{10}$ The late eighteenth-century 'cult of sensibility' also might have encouraged voluntary ghost belief. Ordinary folk had long believed in creatures such

7 Sasha Handley, Visions of an Unseen World: Ghost Beliefs and Ghost Stories in EighteenthCentury England (London, 2007), 217; Walsham, 'Reformation and "The Disenchantment of the World"', 521; Jonathan Barry, 'Public Infidelity and Private Belief? The Discourse of Spirits in Enlightenment Bristol', in Owen Davies and Willem de Blécourt (eds.), Beyond the Witch Trials: Witchcraft and Magic in Enlightenment Europe (Manchester, 2004).

8 See p. 188.

9 Michael Hunter, Robert Boyle, 1627-91: Scrupulosity and Science (Woodbridge, 2000), 244.

10 See p. 190. 
as ghosts without feeling the need to square this belief with kirk teachings, but there was more novelty in the idea that elite folk could confess to belief systems without justifying them in theological terms. This was by no means a widespread pattern, but it suggests that it was at least possible for people at all levels of society to hold supernatural beliefs that did not draw upon Christian theology, and could not be explained in rational terms.

Walsham suggests that instead of looking for a linear process of disenchantment, it might be more useful to think in terms of a 'perpetual spiral of desacralization and resacralization'. She defines 'desacralization' as 'the decline of belief in divine immanence'. ${ }^{11}$ According to this reading, in the immediate wake of the Reformation there was a process of desacralization. England in particular saw resacralization in the late seventeenth and early eighteenth centuries, with the work of figures such as Henry More and Joseph Glanvill. Further reactions against 'barren rationalism' include the development of folklore, the Methodist revival, the rise of romanticism and modern-day interest in the supernatural. ${ }^{12}$ Of course, 'desacralization' and 'resacralization' may be unnecessarily limiting terms as we move out of the early modern period, and magical beliefs cease to automatically entail belief in a deity. The decline of magic within religion cannot necessarily be equated to the decline of magic in general. Nevertheless, the idea that enchantment (to return to Weber's terminology) was cyclical is worth examining further. Considering ghosts specifically, there was certainly a cycle in terms of how many stories were recorded. As outlined above, there was an increase in the late seventeenth and early eighteenth centuries, a quiet spell from about the 1730s to the 1760s, and a surge in the late eighteenth and early nineteenth centuries. However, the late eighteenth and early nineteenth centuries also saw a much greater output of sceptical material on ghosts. Disenchantment and re-enchantment often happened simultaneously, rather than in

11 Walsham, 'Reformation and "The Disenchantment of the World"', 526, 504.

12 Ibid., 526. On the modern-day 're-enchantment of the world' see, for example, Joshua Landy and Michael Saler (eds.), The Re-Enchantment of the World: Secular Magic in a Rational Age (Stanford, 2009); Christopher Partridge, The Re-Enchantment of the West: Alternative Spiritualities, Sacralization, Popular Culture and Occulture, 2 vols. (London, 2004-5); Gordon Graham, The Re-Enchantment of the World: Art versus Religion (Oxford, 2007); Morris Berman, The Reenchantment of the World (Ithaca [N.Y.], 1981). 
alternating cycles. Wodrow and Sinclair's attempts to reclaim ghosts could be classed as re-enchantment, but were a reaction to what they perceived to be a contemporary society-wide disenchantment. Gothic and romantic depictions of ghosts, as well as arguments for their existence within periodicals, were in part a reaction to the medicalised visions that were also popular at the time. Fiction-writers and folklorists recorded and promoted ghost stories while also decrying them as vulgar.

Matters are further complicated by the fact that supernatural beliefs did not all share the same fortune. It was possible for certain beliefs to flourish at the expense of others. The decriminalisation of witchcraft meant that the supernatural largely ceased to be a concern for the secular authorities, which was an important milestone in terms of disenchantment. However, it also meant that there was more scope for ghost stories, both because ghosts were less likely to be rewritten as demons and because there was less risk associated with talking about supernatural experiences. Instead of looking for the decline of magic, it is probably more useful to look for the changes in magic. Different beliefs moved in and out of fashion over time, reflecting shifting social contexts. Many magical beliefs and rituals associated with Catholicism were branded superstitious after the Reformation, but witchcraft took on a new cultural prominence. With the Covenanting Revolution and the Wars of the Three Kingdoms there was a surging interest in special providences. The late seventeenth and early eighteenth centuries saw fresh interest in ghosts, fairies, angels and second sight, alongside continued interest in witchcraft and demonology. Many different beliefs were explored in the late eighteenth and early nineteenth centuries, but ghosts seem to have been particularly popular. Different interpretations of apparitions (and other supernatural beliefs) also moved in and out of fashion. In the case of ghosts there was a trend from ghosts as demons to ghosts as divine messengers to ghosts as hallucinations. This is not to say that newly fashionable beliefs or interpretations were unheard of before, nor that they completely replaced other alternatives. Furthermore, this model tells us more about what we might expect to see in print than what was in people's hearts and minds. Fashion remained limited to those who had the education, leisure time and motivation to pursue it. Even then, it might be a facade. 
Throughout these centuries there were points when magical beliefs of one sort or another were especially in vogue, and the views of believers and sceptics alike become more accessible for the historian. While we do not necessarily see cycles of either disenchantment or re-enchantment, we do see cycles of both at once, interspersed with quieter periods. Sasha Handley suggests that we should view ghost stories as 'an underlying cultural resource which could be called upon at moments of social, political or religious tension'. ${ }^{13}$ It is possible to argue that any point in the eighteenth century was subject to social, political or religious tension, and there are certainly cases of ghost stories emerging in response to major events such as the French Revolution. The pattern of stories as produced in Scotland does not obviously correlate with times of particular upheaval, however. It is very difficult to generalise about the conditions that spurred on the production of ghost stories, because these conditions changed over time, and because the stories varied so much. As Handley implies, however, ghost stories remained a well known genre that could be drawn upon at need to serve particular agendas. These agendas varied as the century progressed; in particular, the religious agenda ceased to dominate educated debates about ghosts. The stories never stopped being useful in one capacity or another, however, and discussion of them flared up when they circled into fashion.

Euan Cameron offers another vision of disenchantment. Looking at Europe as a whole, he argues that a 'considerable gulf' opened between 'the theological elites and the mass of the people' concerning belief in spirits in the eighteenth and nineteenth centuries. By the nineteenth century, these theological elites were no longer very interested in trying to control and direct the beliefs of the folk. Rather than a decline in magic, he suggests, there was a decline in the fear of magic. ${ }^{14}$ He continues:

The key stage in the process of 'disenchantment' may prove to have occurred when transforming the beliefs of ordinary people ceased to generate such desperate evangelical urgency in the minds of the clergy. Religious intellectuals who had undergone the 'disenchanting' process in their own worlds of faith and

13 Handley, Visions of an Unseen World, 212.

14 Euan Cameron, Enchanted Europe: Superstition, Reason, and Religion, 1250-1750 (Oxford, 2010), 14, 27. 
theology felt themselves free to abandon the long-standing and largely failed attempt to disenchant the rest of society. In the process they ceased to worry when poets, dramatists, and folklorists 're-enchanted' the European world in the service of art, culture, or indeed popular entertainment. ${ }^{15}$

The first point to note here is that Cameron's picture of the social hierarchy is more nuanced than the basic model of educated versus uneducated. He is not dividing elite and popular culture so much as separating a particular branch of the latter ('religious intellectuals') from 'the rest of society'. This serves as a useful reminder that it is dangerous to homogenise large social groups. However, it is also worth remembering that there was crossover between ministers and folklorists or writers. Ministers may have been more uncomfortable than other educated people with entertainments such as plays or gothic literature, but there is no real evidence that they held strikingly divergent views on the topic of magic and its place in society, at least in Scotland. It is also debatable whether there was really a long-standing attempt to disenchant society before the eighteenth century. Theological elites certainly took an interest in witchcraft and demonology, and there was no obvious drive to educate the folk about orthodox interpretations of apparitions. As we have seen, there is substantial evidence that many popular magical beliefs and customs survived the Reformation, with the authorities often content to turn a blind eye. The idea that religious intellectuals had a strong fear of the ordinary people's beliefs prior to the eighteenth century is, therefore, questionable. However, it is true that the increased theological flexibility associated with the Moderates facilitated the spread of ghost stories in the late eighteenth century. Cameron's model supports the idea that the key change during the Enlightenment was not that magic declined, but that there was a change in the kirk's relationship with it.

While Cameron's model of social stratification is relatively complex, his idea of a 'great gulf' developing between theological elites and ordinary folk in the eighteenth century is reminiscent of Peter Burke's division of popular and elite culture. Burke argues that the period from 1500 to 1800 saw educated society gradually distancing itself from the entertainments, interests and magical beliefs of the common folk.

15 Ibid., 15. 
From the mid-seventeenth century folklorists were approaching popular culture as something quaint and charming. By 1800, the educated 'had ceased to participate spontaneously in popular culture, but they were in the process of rediscovering it as something exotic and therefore interesting'. ${ }^{16}$ Peter Maxwell-Stuart reinforces this argument with respect to Scotland specifically. He explains the decline of witchcraft as stemming from a 'breakdown in dialogue' between different social classes in the eighteenth century, with the lower classes ceasing to talk to their superiors about witches, magic, or anything else. ${ }^{17}$ This is another area of historiographical debate that is interesting to consider with reference to the changing patterns of ghost stories. On one hand, we can see a degree of social polarisation. Eighteenth-century discussions of ghost belief frequently framed it as the preserve of the uneducated. A work such as Macpherson's Ossian poetry may have revelled in the poetic power of the supernatural, but actual belief was presented as primitive. ${ }^{18}$ The Scottish antiquarian movements provide a particularly clear example. While Wodrow and Sinclair took ghost stories seriously, Martin Martin presented most of the customs he came across as curious superstitions. They were part of a programme of scientific and geographical discovery, but were not to be taken seriously in and of themselves. By the nineteenth century this approach had become the norm. Authors maintained their scepticism, drawing implicit (or sometimes explicit) lines between the folk culture they were writing about, and the educated society they were writing for. For Cameron, the romantics' interest in folklore 'demonstrated how completely Europe's intellectuals had lost their fear of the old "superstitious" cultures' ${ }^{19}$

As we have seen, however, the question of scepticism and belief was not quite so clear-cut. It is also difficult to pinpoint the moment when the investigation of folklorists became more about re-asserting social hierarchies than genuine cultural interchange. Stories were not always presented in a condescending fashion, and the

16 Peter Burke, Popular Culture in Early Modern Europe, 3rd edn (Aldershot, 2009), 270-86, quotation 286.

17 Peter Maxwell-Stuart, 'Witchcraft and Magic in Eighteenth-Century Scotland', in Owen Davies and Willem de Blécourt (eds.), Beyond the Witch Trials: Witchcraft and Magic in Enlightenment Europe (Manchester, 2004), 94-5.

18 See Kenneth Simpson, The Protean Scot: The Crisis of Identity in Eighteenth Century Scottish Literature (Aberdeen, 1988), 68.

19 Cameron, Enchanted Europe, 245. 
circulation of popular ghost stories and ballads in pamphlets, books and periodicals ensured that they could be enjoyed by elites and ordinary folk alike. The story of the Laird of Coul's ghost provides a particularly good example of how narratives could transcend social boundaries. As we have seen, the story began when a servant, William Sinclair, told his local ministers about meeting his late master's ghost in the early 1720s. They recorded his testimony, and it attracted the interest of another minister, William Ogilvie. Ogilvie's account of Coul's ghost fed into an ongoing theological debate, but when it was published as a chap-book it was appreciated more as an entertaining story than for its religious teachings. The subsequent discussion of it in the periodical press shows how it generated interest across the social classes. In the eighteenth century it became more acceptable for educated folk to create, circulate and enjoy ghost stories without worrying about their theological implications. In this sense, the approaches of popular and elite culture were drawing closer. Ghosts had been socially divisive after the Reformation, when they were marked as off-limits for respectable Protestants, but in the eighteenth century the balance shifted. Ghost stories became a cultural artefact that could be shared between different classes. As such, they stand as a caution against overly simplistic pictures of social polarisation. ${ }^{20}$

Finally, it is worth considering how typical the Scottish patterns were. An obvious first point of comparison is England. Handley offers a thorough survey of the patterns of English ghost belief over this period. Her findings indicate that the English developments were broadly similar to those in Scotland, but generally began rather earlier, and were often writ larger. The late seventeenth- and early eighteenthcentury move to reclaim ghosts happened on a much more significant scale in England. This is not surprising. England had a much larger population, a more developed print industry and a more significant Neo-Platonist movement, as well as a less volatile religious context. ${ }^{21}$ The association between ghosts and demons also proved more persistent in Scotland, probably in part because of Scotland's proportionally greater engagement with witch-hunting. As we have seen, Jo Bath and

20 See also Handley, Visions of an Unseen World, 211-12.

21 Ibid., ch. 1. 
John Newton argue that the demonic interpretation was 'only used rarely and sparingly' in late seventeenth-century England; ghosts were more usually associated with the dead. ${ }^{22}$ In Scotland in the same period, the demonic interpretation remained prevalent. Discussion of ghosts in pamphlets and periodicals had its heyday in the late seventeenth and early eighteenth centuries in England, compared to the late eighteenth century in Scotland. The English theatre also flourished long before the art-form became securely established north of the border. ${ }^{23}$ This meant that psychological and physiological explanations for ghosts, as well as dramatised representations of them, reached wide circulation earlier in England. ${ }^{24}$ It was only in the late eighteenth and early nineteenth centuries that Scotland caught up with England in terms of engagement with ghosts.

England was at the centre of the drive to reincorporate ghosts into Protestant theology in the late seventeenth and early eighteenth centuries, but there were echoes of the movement in other countries. Jürgen Beyer writes that 'reports about known individuals returning after their death with a message seem first to be available in the Lutheran countries from the late-seventeenth century onward'. ${ }^{25}$ The German polymath Erasmus Francisci published stories 'proving' the reality of ghosts in the late seventeenth and early eighteenth centuries, while the Dutch minister Jacobus Koelman translated Glanvill's story of the Drummer of Tedworth. ${ }^{26}$ As in Scotland and England, the intellectual developments of the Enlightenment prompted discussion of the supernatural. ${ }^{27}$ In Germany in particular, leading philosophers engaged in a sustained analysis of ghosts. Immanuel Kant's 1766 Dreams of a Spirit Seer, written as a response to Emanuel Swedenborg, explored the idea that the human

22 Jo Bath and John Newton, “'Sensible Proof of Spirits": Ghost Belief during the Later Seventeenth Century', Folklore, cxvii (2006), 3-4. See p. 58.

23 Handley, Visions of an Unseen World, chs. 2, 4.

24 Ibid., 197-208, 113-14, 130-2. See also Owen Davies, The Haunted: A Social History of Ghosts (New York, 2007), chs. 8, 5; Terry Castle, The Female Thermometer: Eighteenth-Century Culture and the Invention of the Uncanny (Oxford, 1995), ch. 10; Shane McCorristine, Spectres of the Self: Thinking About Ghosts and Ghost-Seeing in England, 1750-1920 (Cambridge, 2010), ch. 1.

25 Jürgen Beyer, 'On the Transformation of Apparition Stories in Scandinavia and Germany, c.1350-1700', Folklore, cx (1999), 45.

26 Sabine Doering-Manteuffel, 'The Supernatural and the Development of Print Culture', in Owen Davies and Willem de Blécourt (eds.), Beyond the Witch Trials: Witchcraft and Magic in Enlightenment Europe (Manchester, 2004), 190; Cameron, Enchanted Europe, 281.

27 See Cameron, Enchanted Europe, ch. 18. 
soul might constantly and unconsciously communicate with the 'immaterial natures of the spirit world'. Kant suggested that some particularly sensitive individuals might experience these communications as external forces, and mistakenly think that they were visited by spirits. He added that 'departed souls ... can never, it is true, be present to our outer senses ... but they may indeed act upon the spirit of man'. He also presented an alternative reading that dismissed ghosts as products of an overactive imagination, likening them to optical illusions. ${ }^{28}$ In the nineteenth century, serious discussion of apparitions continued, involving figures such as Georg Wilhelm Friedrich Hegel and Arthur Schopenhauer. ${ }^{29}$ As Kant noted, there was a big market for ghost stories. ${ }^{30}$ Annekatrin Puhle has catalogued more than a thousand stories of poltergeists and ghostly apparitions published in Germany between 1700 and 1900, as well as about a hundred titles from before that period. ${ }^{31}$

It is natural to assume that Protestants and Catholics would follow different patterns when it came to ghosts. However, contemporaries tended to rather overstate the differences. For all Keith Thomas's claims that ghosts became a shibboleth by which to distinguish Protestants and Catholics, English Catholics do not seem to have been more inclined to tell ghost stories than their Protestant counterparts in the period after the Reformation. ${ }^{32}$ The Catholic Reformation powered a drive to stamp out superstition just as had the Protestant Reformation. As we have seen, there was plenty of overlap between the approaches of the Protestant Ludwig Lavater and his Catholic opponents Pierre Le Loyer and Noel Taillepied. Analysis of French and Spanish stories from the sixteenth and seventeenth centuries has revealed a significant degree of doubt among the authorities as to how apparitions should be interpreted. ${ }^{33}$ This confusion persisted into the eighteenth century. Antoine Augustin

28 Quoted in Stefan Andriopoulos, Ghostly Apparitions: German Idealism, the Gothic Novel, and Optical Media (Cambridge [Mass.], 2013), 26-9.

29 Ibid., ch. 2.

30 Ibid., 24; see also Doering-Manteuffel, 'Supernatural and the Development of Print Culture', 192.

31 Annekatrin Puhle, 'Ghosts, Apparitions and Poltergeist Incidents in Germany between 1700 and 1900', Journal of the Society for Psychical Research, 1xiii (1999), 292.

32 Keith Thomas, Religion and the Decline of Magic: Studies in Popular Beliefs in Sixteenth and Seventeenth Century England (London, 1971), 703; Francis Young, English Catholics and the Supernatural, 1553-1829 (Farnham, 2013), ch. 3; Handley, Visions of an Unseen World, 172.

33 See Timothy Chesters, Ghost Stories in Late Renaissance France: Walking by Night (Oxford, 2011), ch. 2; William A. Christian, Apparitions in Late Medieval and Renaissance Spain (Princeton, 1981), ch. 3. On the Catholic approach see also Cameron, Enchanted Europe, 286-94. 
Calmet's extensive work on apparitions and vampires (1746, revised 1751) allowed some ghost stories to be true, but depicted others as forgeries. ${ }^{34}$ After analysis of the French case, Fernando Vidal concludes that 'the experience of ghosts revealed a large common ground between Christian religious denominations'. ${ }^{35}$

Folklorists have identified a transformation in story-telling across Europe in the eighteenth century. ${ }^{36}$ Fictional forms of writing evolved, the press became freer and books became more easily available. In Germany and France as in Scotland and England, ghosts took on important roles in gothic literature, and were used to explore a pyschologised form of horror. Again, religious differences were of minimal importance: Daniel Hall argues that German gothic was more comfortable than French gothic with presenting genuine apparitions. ${ }^{37}$ As in Scotland, interest in supernatural stories surged in the late eighteenth century. In Germany there was an 'explosion in esoteric and occultist pamphlets, flyers, novels and treatises' ${ }^{38} \mathrm{H}$. C. Erik Midelfort identifies a period of 'increasing spiritualist enthusiasm' in Berlin in the 1780s, encouraged by William II's rise to the throne of Prussia. William 'supported ministers and courtiers devoted to religiously conservative, mystical, visionary, and anti-Enlightenment projects', with the result that 'ghosts and other spiritual bodies were suddenly back on the cultural agenda, and empirical evidence, at least, seemed to support their existence' ${ }^{39}$ In France, the popularity of mesmerism in the 1780s prompted renewed interest in apparitions as a topic, while England also saw a fresh boom of enthusiasm for occult matters from this decade. ${ }^{40}$ The development of a romantic-nationalist programme of antiquarian studies in the nineteenth century can also be traced across Europe, and is often said to have

34 See Fernando Vidal, 'Ghosts of the European Enlightenment', in Mu-chou Poo (ed.), Rethinking Ghosts in World Religions (Leiden, 2009).

35 Ibid., 177.

36 Beyer, 'Transformation of Apparition Stories', 39.

37 Daniel Hall, French and German Gothic Fiction in the Late Eighteenth Century (Bern, 2005), 193.

38 Andriopoulos, Ghostly Apparitions, 80.

39 H. C. Erik Midelfort, Exorcism and Enlightenment: Johann Joseph Gassner and the Demons of Eighteenth-Century Germany (New Haven, 2005), 147.

40 Robert Darnton, Mesmerism and the End of the Enlightenment in France (Cambridge [Mass.], 1968); Paul Kléber Monod, Solomon's Secret Arts: The Occult in the Age of Enlightenment (New Haven, 2013), ch. 7. 
originated with the work of the Brothers Grimm in Germany. ${ }^{41}$

Overall, discussion of ghosts in the major Enlightenment centres seems to have followed similar patterns. Furthermore, although Paul Kléber Monod argues that Scottish and English attitudes towards the occult diverged in the second half of the eighteenth century, their approaches to ghosts seem to have been broadly consistent, with the exception that English developments often happened earlier and on a larger scale. $^{42}$ There was, however, one distinctive feature of the Scottish approach. It relates to the way in which ghosts became entangled with national identity. In the late eighteenth and early nineteenth centuries, Scotland developed a reputation as a particularly haunted country. Admittedly, there are other claimants to this honour. Owen Davies opens The Haunted with the suggestion that England has long been seen as a particularly 'ghost-ridden nation'. ${ }^{43}$ Nonetheless, the popularity of the Ossian poetry gave the Highlands a reputation for romantic wildness that was probably unparalleled. For authors such as Ann Radcliffe and Sophia Lee this made the area a natural setting for gothic stories, the 'proper home of the poetic and the sublime'. ${ }^{44}$ An 1842 article declared: 'Were we seriously asked what part of Christendom, whether in remoter ages or comparatively modern times, was most troubled with supernatural horrors, we should without doubt or hesitation, answer, "Scotland." It went on to explain that when it came to ghosts, the "best known and most widely diffused of all the spectral race', Scotland had more than any other part of Europe, and probably more than half of Europe put together. ${ }^{45}$ Scotland was unusual, moreover, in developing a ghost of its own: the hearty Gaelic ghost, who duelled with unsuspecting travellers or watched over its ancestors. These ghosts were reminiscent of themes in Icelandic folklore and Irish mythology, but were nevertheless distinctly Scottish, and drew on popular notions of the Highlands.

41 See Jack Zipes, 'Introduction: The Golden Key to Folk and Fairy Tales: Unlocking Cultural Treasures', in Jack Zipes (ed.), The Golden Age of Folk and Fairy Tales: From the Brothers Grimm to Andrew Lang (Indianapolis, 2013), xvi-xviii, xxviii-xxxiii, esp. xxxii.

42 On Monod see p. 6.

43 Davies, Haunted, 1.

44 Timothy C. Baker, Contemporary Scottish Gothic: Mourning, Authenticity, and Tradition (Basingstoke, 2014), 3. The quotation is Baker's summary of Radcliffe's thinking.

45 'A Sketch of Scotch Diablerie in General', Fraser's Magazine for Town and Country, Mar. 1842, 317,318 . 
The association between folk tradition and national identity was drawn in other countries as well, but the figure of the ghost specifically took on greater importance in Scotland than elsewhere. Germany perhaps saw the most high-profile discussion of ghosts in the eighteenth and early nineteenth centuries, but ghosts were not particularly prominent in the tales of the Brothers Grimm, while other German folklorists went so far as to suppress 'mere ghost stories' ${ }^{46}$ In France, folklore played a relatively minor role in the formation of national identity. ${ }^{47}$ As for England, Sasha Handley writes that ghosts were a significant component of 'individual, community and regional identities', but despite Davies's mention of plentiful hauntings, the historiography has not identified them as particularly important to concepts of nationhood. ${ }^{48}$ Ghosts were pressed into service as Scottish symbols because of the country's political circumstances. As the weaker party in a union that much of the country had not wanted, Scotland had particular incentive to fashion a distinctive reputation. Its long-standing reputation for magic, combined with the wildness of the Highland landscape, meant that supernatural figures of some sort were fitting mascots. Ghosts were particularly suitable because they offered a way of recalling bygone eras, and so aligned well with the romantic agenda of building the present upon a sentimentalised past. For Macpherson they were a majestic alternative to the wizards and hags of his source material. He was not the first to use ghosts to symbolise a romantic past Scotland, but he was responsible for the widespread popularisation of the archetype. This image of Scottishness may have drawn little on genuine folkloric traditions, but conceptualisations of national identity could be powerful even when built on myths. Moreover, Scotland's haunted reputation was a self-fulfilling prophecy: it inspired further stories that fed into perceptions of the nation through the nineteenth century and beyond.

46 Ines Köhler-Zülch, 'Heinrich Prohle: A Successor to the Brothers Grimm', in Donald Haase (ed.), The Reception of Grimms' Fairy Tales: Responses, Reactions, Revisions (Detroit, 1993), 47, $54 \mathrm{n} 15,54 \mathrm{n} 17$.

47 Anne Dymond, 'Displaying the Arlésienne: Museums, Folklife and Regional Identities in France', in Timothy Baycroft and David Hopkin (eds.), Folklore and Nationalism in Europe During the Long Nineteenth Century (Leiden, 2012), 137.

48 Handley, Visions of an Unseen World, 186. 
This is not to say that approaches to ghosts remained static as the nineteenth century progressed. The big newcomer to the supernatural scene was the spiritualist movement. It reached Britain in the $1850 \mathrm{~s}$ and garnered a wide following in Scotland. The Glaswegian Daniel Dunglas Home was a celebrated medium not only locally, but across Europe. ${ }^{49}$ The spiritualist movement gave humans a new degree of power over ghosts. Ghosts returned not of their own accord or by divine or demonic agency, but because a medium had summoned them. ${ }^{50}$ Nevertheless, the spiritualist movement drew on older patterns. Mediums called upon ghosts to reassure and comfort the living, much as did the Scottish ballads. Spiritualism also relied upon the eighteenth-century secularisation of magic: the shift in power from the deity (or the Devil) to the human medium was only possible because orthodox religion had lost its monopoly on ghost stories. The influence of eighteenth-century attempts to explain ghosts is also apparent. In 1882 the Society for Psychical Research (SPR) was founded, as a consequence of 'the efforts of a number of spiritualists to place their beliefs on a sound, unprejudiced and, as befitted the age, scientific footing, ${ }^{51}$ While it was based in London, the SPR's reach extended to Scotland, and Scotsmen Balfour Stewart and Andrew Lang were among its founders. Its investigations into apparitions were more thorough, organised and scientific than anything that had come before, but many of its conclusions were familiar. In particular, the SPR took a keen interest in psychological and physiological explanations for ghosts. Shane McCorristine writes that it 'proposed an advanced theory of hallucination which consummated a century of medical and psychiatric debate'. ${ }^{52}$

The SPR explored both natural and supernatural explanations for ghosts, and demonstrates once again the overlap between scepticism and belief, processes of disenchantment and re-enchantment. Tracing ghost beliefs up to the present day reveals a similar pattern. Polls suggest that British levels of ghost belief have more than doubled since the Second World War, even though this period has been

49 Janet Oppenheim, The Other World: Spiritualism and Psychical Research in England, 1850-1914 (Cambridge, 1988), 10-17.

50 As noted by Handley, Visions of an Unseen World, 214.

51 McCorristine, Spectres of the Self, 104.

52 Ibid., chs. 3, 5; quotation 105. 
associated with progressive secularisation. ${ }^{53}$ If there were tentative hints, by the late eighteenth century, that it might be possible for educated folk to believe in ghosts without reference to the Christian framework, nowadays that approach is securely established. Other aspects of eighteenth-century development also remain pertinent. The concept of ghosts as mediators between the educated and the illiterate may have less relevance to contemporary society, but ghosts are still wrapped up with romanticised readings of Scottish history, and continue to be marketed as a national attraction. ${ }^{54}$ They also linger on in the worlds of psychological research and journalism. ${ }^{55}$ The horror genre persists in exploring the ghost's sinister potential, and the romantics' white-sheeted ghost traipses the streets in diminutive hordes each Hallowe'en. Eighteenth-century attitudes towards ghosts emerged from specific political, religious and social contexts, but also reflect more enduring concerns: to find comfort in the face of death; to understand the workings of the human mind; to preserve traditional folk tales; to conceptualise national identity; or simply to enjoy the thrill of spooky stories.

Trying to fit ghosts into neat conceptual frameworks reveals just how elusive they can be. In the eighteenth century, they got a foothold in respectable society because they were reinvented as religious propagandists. They prospered thereafter because they became progressively more secularised. Scientific explanations of ghosts as hallucinations flourished at the same time as visions of gloomy spectres stalking churchyards. Stereotypes of ghosts encompassed divine messengers, lovelorn maidens, monstrous tomb-dwellers, Highland warriors and snickering servants in white sheets. It is the ghost's capacity to take on a range of meanings, however, that has made it such a resilient figure. Ghosts can be harnessed in service of a wide spectrum of social, political and religious agendas. It is in few people's interest - and least of all the historian's - to let them rest in peace.

53 Paul Cowdell, 'Belief in Ghosts in Post-War England' (University of Hertfordshire PhD thesis, 2011), 1-2.

54 This can be seen in numerous collections of Scottish ghost stories. For a typical example see Dane Love, Scottish Ghosts (London, 1995).

55 See, for example, the work of the Koestler Parapsychology Unit, which is based in the Psychology Department at the University of Edinburgh. On journalism see Cowdell, 'Belief in Ghosts', 1. 


\section{The Letters of James Cowan}

These letters are preserved in one of Robert Wodrow's folio volumes of materials in the National Library of Scotland. ${ }^{1}$ They probably date from around 1707 . This is based on their place within Wodrow's chronologically arranged folio, as well as a reference to James Grierson as being 'lately ordained Minister in Tingwall', which happened in September $1706 .^{2}$ The letters are not signed, but Wodrow indicates that they came from a Mr. J. C. This was the James Cowan who also wrote a passage in Wodrow's Analecta, containing some twenty stories of strange providences. ${ }^{3}$ Cowan was licensed by the Presbytery of Haddington in 1700 and ordained in 1717. He began to work in Dundonald, South Ayrshire, but stepped down soon afterwards. On 5 February 1722, Wodrow noted that 'Mr James Cowan, Minister at Dundonald, is to demit, not being advised to abide a tryall'. The Fasti Ecclesiae Scoticanae records that he stepped down in 1723 'on account of inability or unfitness' ${ }^{4}$

The letters are written in a close italic hand on both sides of Folio-sized paper. The left-hand margins are about $1.5-2 \mathrm{~cm}$; there are no right-hand margins; the margin at the top of the first pages of each letter is about $3 \mathrm{~cm}$, after which the top margins are about $1 \mathrm{~cm}$; the bottom margins are about $0.5 \mathrm{~cm}$. The first letter spans about three and a half sides in total, and the second letter two and a half sides.

\section{Editorial methodology}

Original spelling, capitalisation and punctuation have been retained for the most part. However, for the reader's convenience I have occasionally inserted full-stops, and

1 James Cowan to Robert Wodrow, [1707]: NLS, Wod.Fol.XXVIII 4846, fos. 222-225.

2 Hew Scott, Fasti Ecclesice Scoticance, new edn, 7 vols. (Edinburgh, 1915-28), vii, 291.

3 Robert Wodrow, Analecta, NLS, Wod.Anal, fos. 139-182. Printed version: Robert Wodrow, Analecta: Or Materials for a History of Remarkable Providences Mostly Relating to Scotch Ministers and Christians, ed. Matthew Leishman, 4 vols. (1842-3), i, 98-118.

4 Wodrow, Analecta, ii, 358; Scott, Fasti, iii, 36. 
capitalised the first letter of the following word (capitals after full stops that were originally Cowan's are italicised). I have also inserted paragraphs. The full stops are marked as my own by the use of square brackets: [.] All non-indented paragraphs are mine.

Contractions (\&, yt, wth, etcetera) have been silently expanded, and I have modernised the usage of $i, j, u, v, s, b$. The Scots feature of using $w$ for $u$ is taken here as a point of spelling rather than orthography, and thus retained.

$<_{\ldots}$. > indicates deleted text. Where it can be read the text is supplied; otherwise, dots indicate the approximate number of deleted letters.

$\{\ldots\}$ indicates text that is illegible due to fading or ink blots. Where it can be inferred this text is supplied; otherwise, dots indicate the approximate number of illegible letters.

Repeated words on a new page have been deleted. 


\section{Letter One}

R. D. S. ${ }^{5}$

Mr David Thomson minister of Kinnell, in the Shire of Angus, of the Episcopall persuasion, happening to dye in the Monneth of June or July 1703 the following story concerning him was reported to me some eight or ten dayes befor his death, by Mr John Dowgald present Minister of the Gospel at Rescoby, who was his intimat freind, \& acquaintance \& formerly Copresbiter with him in the Presbitry of Brechin, who had it from his own Mouth, Which is as follows. ${ }^{6}$ Mr David Thomson after he had past his Course at the University, when a youth, was Chaplain to this present Earle of Perth, haveing wpon a certain time gone abroad to see freinds about Six or Seven miles from the Castle of Drummond, As he was returning home being well mounted wpon one of My Lords horses, there was a River which he was to pass, which by reason of a great fall of Rain the day befor, was now become unpassible,[.] Wherepon he calls at some people who lived not far from the watersyd to know whether or not the foord was rideable,[.] They told him, $<\mathrm{W}>$ Sir we cannot well advyse yow, the water is truly great, but seeing yow are well Mounted we think yow may adventure to take it[.] Wpon which he goes streight forward to the foord with a full resolution to ryd through, but when he was just ready to take the water, There comes wp to him a handsome young Gentleman of a Sweet Lovely Countenance with something of Majesty in it well equip'd and mounted on a very fine horse, finer then any that ever he saw who passed by him very swiftly, \& springs in befor him into the water, without speaking a word, \& who had not gone in twice or thrice the horses length into the water till both horse $\&$ man goes down, over head \& ears, so that Mr Thomson lost sight of both,[.] But immediatly he springs wp turns the horses head \& Comes $<\ldots .>\&$ then addresses Mr Thomson thus, Sir yow see the water is not rydable here but please to goe along with me a litle further wp the water, $\&$ under God I'le conduct yow safely through at another place where it is rydable, which $\mathrm{Mr}$ Thomason with aboundance of assureance \& pleasure Complyes with,[.]

5 Reverend Dear Sir.

6 David Thomson was born in 1649 and ordained in 1678. He died in 1702. Scott, Fasti, v, 442. John Dougal was born in 1653, called in 1703, and died in 1723. Ibid., 302. 
\& when they were come to the place The young Gentleman sayes to him Now Sir I'le take the water befor yow, follow yow immediatly after \& observe the track of my horse exactly without turning in the least to the right or left hand otherways yow are gone[.] Which he observing very carefully, it happened that the water came but wp to the horses belly \& so they came both safely through to the other syd, which was a plain spot of ground, being a Moor of about two Miles in length, \& farr from any house,[.] The Gentleman then addresses Mr Thomson thus, Now Sir yow have mett with a signale deliverance, bless God for it, \& Never forget this day while yow live for if I had not come wp to yow in the very Nick of time when yow were entring the water, yow would undoubtedly have perished. And Remember further, that in the fiftyeth year of your age yow will dye of a fever,[.] And after that he intertain'd him with a heav[en]ly discourse which was very raveshing, \& presently Evanished so that Mr Thomson could not see him, far nor Near there being Neither house nor hole, nor any thicket within sight, or hard at hand where he might have absconded himself. All that I heard Mr Thomson should have observed, further concerning this person was that when he came our of the water there was not one hair either of horse or man wett.

\section{Revd Sir}

This ${ }^{\wedge}$ foregoeing story I had from Mr John Dowgald my very good freind \& intimat acquaintance while I stayed at Brechin, where he \& his family were dwelling for the present. About a twelve monneth befor $\mathrm{Mr}$ Thomsons death $\mathrm{Mr}$ Dougald \& I being both wpon the supplies were traveling home [to] Brechin \& happening to ryd by Kinnell he was giveing me the Character of $\mathrm{Mr}$ Thomson, viz that he was a man of a good sober walk \& Conversation, a kynd Courteous temper, very bookish $\&$ intearly devoted to his studys to such a degree that he had lost one of his Eyes by excessive reading, a Sound Calvinist tho he had Complyed with Episcopacy, his father was a Zealous Presbiterian Minister I suppose in Fife which I had from Mr Patrick Tullidaph ${ }^{7}$ who saw Mr Thomson at his house when he was in these bounds wpon the supplyed, at the same time with my self. And so Mr Dowgald

7 Probably Patrick Tullidelph, who was ordained in 1697 and died in 1709. He was minister of Ferryport on Craig. Scott, Fasti, v, 201. 
inclineing to touch at Kinnell too see Mr Thomson, wad needs have me to goe alongst with him which I did answer the same[.] So far as I was capable to know in such a short time being less then two houres I found him to be of a very aggreable Conversation \& so we parted,[.] About less then a twelve monneth after I happening to be in Mr Dowgalds house in Brechin where I was frequently he began thus with Me after his usuall \& familiar way of Manner, Billie I have news to tell yow[.] ${ }^{8} \mathrm{Mr}$ David Thomson whom yow \& I saw at his hous is dying of a fever \& I have some assureance that he will dye at this time,[.] $I$ enquired what was the ground of his assureance,[.] He answered Mr Thomson got a warning many years agoe that he wad dye of a fever in the fiftyeth year of his age $\&$ so he told me the whole foregoing story,[.] $I$ answered we must suspend our thought till we see whither he dyes or recovers $\&$ the event will determine ws, which it did for in 8 or 10 dayes after he dyed. I thought it was not amiss to give yow ane account of these Circumstances particularly this last \& so subjoyn the Same to the Story. I am

Yours

\section{Sir}

The following Story is more foraign, no less strange, tho indeed I cannot say so very well vouch'd. My author who reported it to me was Mr Archibald Lundy Minister of the Gospell at Saltoun, who I doubt not, can give a better \& fuller account of it Now then when I saw him. ${ }^{9} \quad$ It is concerning one Mrs Turbervill sister to Mr Turbervile a famous Occulist at London[.. ${ }^{10}$ She lived in a Cuntrey house some 50 Miles from

8 The term 'billie' meant a close friend or comrade.

9 Archibald Lundie was baptised in 1674, ordained in 1696, and died in 1759. Scott, Fasti, i, 393.

10 Mary Tubervilll was from Wayford, Somerset. Her dates of birth and death cannot be determined, but her will was made from St Andrew Holborn in 1702. She earned some contemporary renown for two reasons. Firstly, she took over her brother's medical practice after his death, enjoying 'good Reputation and Success'. Secondly, she saw another ghost in Salisbury, and helped it to restore its children's inheritance. This was apparently 'much talked of', and the story was told (albeit very briefly) by John Aubrey, and later by Daniel Defoe. Cowan's story may, of course, have its roots in this story of Aubrey's (or vice versa), but the geographical locations and the purpose of the ghosts are different in each. Regarding her brother, Cowan's information is long outdated: Daubeney Turberville died in 1696. Walter Pope, The Life of the Right Reverend Father in God, Seth, Lord Bishop of Salisbury (London, 1697), 108; John Aubrey, Miscellanies Upon the Following Subjects (London, 1696), 63-4; Daniel Defoe, An Essay on the History and Reality of Apparitions (London, 1728), 290; Barbara Beigun Kaplan, 'Turberville, Daubeney (1612-1696)', Oxford DNB (Oxford University Press, 2004), http://www.oxforddnb.com/view/article/27823, accessed 1 Aug. 2015; Will of Mary Turbervill, 13 May 1702, TNA, Prob 11/464/369; Will of Dawbeny Turbervill, 14 May 1696, TNA, Prob 11/431/438. 
London, the landlady of which house $<$ being $>$ lately dead when she came to it[.] It happened that one Evening in the twilight as she was comeing out of ane Upper Chamber \& resolving to goe down stairs she saw wpon the stairhead a terrible apparition of a woman all in black with a very ugly face \& a Countenance full of horror sending forth a Noysom Smell, which did not a litle Strike Mrs Turbervile with fear \& Consternation[.] But passing by the Specter she came down stairs, \& thinking it proudence not to reveall to any what she had seen she betake her self presently to her Closet for prayer \& haveing begged the Divine protection \& indeavoring to blot out of her Memory \& Phansie the frightfull idea of what she had seen she began to take heart \& Curage again,[.]

$\&$ the Nixt Night when it was dark she went wp to the same room with a lighted Candle in her hand, where the ghost appeared to her again in the Same terrible manner as befor viz all in black with a horrible ugly Countenance Casting out a Noysome Smell, \& which was yet more terrible to her then befor the ghost was within the room standing betwixt her and the door so that ${ }^{\wedge}$ Now she knew not what way to get out[.] \& therefor she falls down immediatly \& prayes with great fervour that God might preserve her from the assaults of the Evil one both outward \& inward \& that she might be strengthned with faith \& Courage against Naturall fear \& Unbeleif[.] \& haveing insisted thus in prayer for some litle time she ryses from her knees \& with some boldness \& confidence in the Divine mercy \& protection she bespoak the Ghost thus[:] In the Name of the Lord what art thow \& why am I so disturbed \& affrighted by such a dreadfull appearance, $<\mathrm{I}>$ tho I have been guilty of many sins yet I have fled to the mercy of God \& merits of Jesus Christ in whom I hop for a Compleat pardon of them all \& by the Divine goodness I have bein hitherto kept back from gross presumptuous sins \& therefor in the name of the Lord be gone $\&$ disturb me no more;[.]

The ghost Answers It is well yow have spocken first, for if yow had not I would have torn yow, \& thrown yow down Stairs; \& now I'le tell yow what I am \& for what end I have appeared to yow. I am the Ghost or spirit of the deceast Landlady of this house,[.] My husband \& I in our lifetime alotted \& mortifyed a Considerable 
somme of monney for the releif of the poor \& My husband dying befor me on his death injoyned me to apply \& dispose of that monney as we had both aggread to befor, which I was willing to doe, but through negligence or forgetfulness left it undone as long as I livd,[.] \& Now I am under great horror \& $\wedge^{\wedge}$ can be at no rest till it be disposed of \& except yow do what I shall just now enjoyn yow, I will haunt yow continually,[.] What shall I doe sayes Mrs Turbervile,[.] The Ghost answers take the Candle in your hand \& follow me wp the trap stair to the Garret $\&$ yow need not be affrayed for I will doe yow no harm. which she did, when they were there the Ghost says the monneys lodged in this garret $\&$ points to the place which was betwein the boards of the Roof \& the Tyle where there was a rent or Slitt in at which the ghost bids her thrust her arme as far as she could reach towards such a side \& there she should find a large Napkin full of gold $<$.> monney, which none of the world knew of or where it was except she had appeared to discover it, Which Mrs Turbervile did find the monney \& brings it out, the Ghost sayes the Soumes \{intear?\} to the value of So much then it sayes yow must be at the pains \& Expence of goeing to London with this monney $\&$ deliver ${ }^{\wedge}$ it to a brother in Law of mine who knows that there was so much monney Mortifyed by my husband $\&$ me ${ }^{\wedge}$ but knows not what is come of it $\&$ if yow tell him the whole Story of my appearing to yow he will belive yow, \& enjoyn him from me to Dispose of it as it was designed with certification that if he doe it not I will haunt him continually,[.] And for a reward of your pains \& diligence after yow are returned I will appear once more to yow but in a glorious manner \& not to your terror \& will satisfy your curiosity by answering such questions as yow shall propose to me but not beyond the number of 5 or 6,[.] This Mrs Turbervile undertakes to do \& so the Ghost evanishes,[.]

When she came to London she told the whole Story to the Gentleman \& delivered the monney to him $<$.. . > found that there was not a farthing wanting he belived her report gave her a Recepit of the monney \& promised to dispose of it accordingly as was said,[.] After Mrs Turberviles return, the Ghost appears to her again in the day time when she was all alone in a Chamber, but then she appeared all in white with a pleasent beautifull \& smileing Countenance, \& spoeak to her thus, Now Mrs yow have done well I am now in perfect peace $\&$ shall no more truble yow $\&$ am ready to 
answer your Questions,[.] Mrs Turbervil who had her thoughts wpon them befor began with the first which was this, Whither or not are yow the real spirit or ghost of that woman who was mistris of this house, or am I only deceaved with a phantom, or ane apparition of the Devil[.] If yow be the real Spirit of that woman then seing yow are in the State of the dead $<$ then $>$ Let me know whither or not yow are blessed or damned \& whither yow have bein in Heaven or Hell. The answer was I am the reall Spirit of the Late Landlady, I am in the State of the dead $\{\ldots . .\}<..>$ be $\&$ as for that part of the Question whither were yow in Heaven or in Hell, As yet I have bein in neither but have bein under great horror till this business was dispatchd[.] Now I am perfectly free of all anxiety and [am] in a State of bliss I am presently to pass into Heaven. a Confirmation of which yow shall have befor I part.

Mrs Turbervil proposed. More Questions to the Number of five but our author could give account of none of them but two more \& that Comprised \{by?\} \& in the general. The one was as I remember concerning some futur Event which she got Satisfaction,[.] The other was too Curious for the Ghost said bewar of proposeing $<$ such $>$ that Questione for $<$ they are $>$ its too Curious \& with that gave her a litle Nip in the arme which Smarted for a time. \& then the Ghost Sayes Now as was promised for a reward yow shall have a short \& swift glance of that glory which I am to pass into, $\&$ immediatly the room shone with a glorious light $\&$ she appeared all Shineing $\&$ then there appeared a pleasant young child of wonderfull beauty who laid his hand beneath the sole of her foot $\&$ so lifted her streight wp from the floor of the Chamber till her head reacht the roof $\&$ as she was ascending Mrs Turbervile heard the most melodious sound of musick that ever mortall heard so excellent that the finest Organnall musick in Churches when compared with it was but like the gruntling of a Sow as she expressed.

Sir This is the story as I heard it with all the Circumstances thereof. Only as I was informd there were some Gentlemen either of Scotland or England who in the way to London were So curious as to goe off their road to see this Mrs Turbervile $\&$ get the Confirmation of the Story from her own mouth. I am Yours 


\section{Letter Two}

R. D. S.

There was a very rare and Memorable story which I heard lately at Edinburgh and which I thought fitt to Communicat to yow and I doubt not but it will be worth the pains not only of the more Curious and inquisitive sort of Men, but like-wayes of those who are truely and zealously concerned for the state of Religion at this time, to make $<$ an $>$ exact inquiry into the truth of the same as possible[.] The story as I heard it is as follows; There was a worthy Lady in England in the County of Sussex, as I remember, of rare and eminent piety, and devotion who after some sickness happened to dye,[.] Her husband a pious Gentleman was so affected with sorrow for the loss of so excellent a Christian and so dear a relation that his grief did swell beyond its due bounds, to such a degree, that for three dayes he did, neither eat drink not sleep, or at least did not take so much refreshment as was necessar to sustain Nature, but all the while sat pensive, murning over the body of his deceast wife, which was laid wpon the bed not being as yet put into the Coffine,[.] His freinds came frequently to him to take him out of the room but could not prevail,[.] At last it being near the fourth day they began more sharply to chyde him and expostulat with him telling that by so doeing he acted neither like a man nor a Christian, nor like himself at former times, while he mourned as those who have no hop was so Cruel to himself, provocked God and dishonored the body of his dear wife, whose soul, they had reason in all Charity to judge, was now in a glorifyd state,[.] He answered yow nor the $<\mathrm{w}>$ world knew not the worth of this woman who was the rarest saint in her age for by her prayers she obtaind not only blessings for her self, her family and me in particular, but for the whole Church of God and therefor how can I but bewail so great a loss at a more than ordinary rait; they replyed tho all this be true yet now seing she is gone it remains that yow say with Abraham of his beloved Sarah, I must bury my dead out of my sight, ${ }^{11}$ and so we intreat yow remove, that the last office may be performed which we owe to the ashes of the dead, otherwayes know that of necessity we must take yow hence by force;[.] He at last condescends to remove,

11 Gen. 23:4, King James version (all Biblical citations come from this version). 
upon condition that he might be allowed to stay four houres in the room with the body. $\mathrm{A}<\mathrm{a}>11$ alone, the doors being closs shutt, which was granted,[.]

While he was there, and when he had, no doubt, bein at prayer, he takes a steddy view of the body, which was lying with the face open, and perceaves a $<$.> ruddiness to appear in the lips and Cheecks, at which being strangely surprized, he approaches nearer and takeing a grip of the hand he feells not only a pulse but a warmth and within a very litle he observes her to open her eyes which made him presently to Cry out $\mathrm{O}$ my dear are yow alive, or, are yow again returned to the liveing, wpon which she raises her self, sitts up streight in the bed, and with a kind of froun spoak to him and answered Yes I am, and No thanks to yow,[.] O then sayes he let me know where and in what state yow have been and what is the state of the dead, she \{re\}plyes, Ask me no further concerning these things at present but call immediatly for the Minister of the place and I will reveall to him what I have to say allowing yow to be witness, which was done,[.] The Minister came, and all in the family were injoyned secrecy, but none allowed to be present with her when she gave the account but the Minister and her own husband; she desyred the Minister to take paper and to write from her mouth what she was to say and thus she began;[.]

I was $<.>$ really dead, and in the state of the dead, My soul was actually dislodged and separate from my body, and I perceaved that My soul flew with incredable swiftness through the thickest pairt of the $\{$.$\} wall of this room meeting with no$ resistance therefrom, no more then when Men walk or run through a Mist or fog. and infinitly less. presently says she I was attended by two guardian Angels appearing like two beautifull youths of a glorious aspect a Majestick Mien Mixd with a great deal of sweetness, she observed in the one something more of a reserved greatness, in the other something more of a tender warmness as it were, and familiar kyndness, $[.]^{12}$ Being thus attended by her heavenly guardians she told that she flew with a wonderfull and inconceaveable suiftness through a great pairt of this Earth and, which is very observable she said she both heard and saw things, now in this her separat state, as well, nay far more exquisitly then when in the body, for as she was

12 See Luke 16:19-31: Lazarus is 'carried by the angels into Abraham's bosom'. 
passing through a great many Countreys, Kingdoms and Cities, of all which she could give ane exa $\{c t\}$ description, she saw $<\ldots>$ the people and what they were doeing and heard what they were saying and that at a great distance, and which was yet more she then understood the language of each Nation, tho she never knew it befor. When they had taken this short and wonderfull survey of the Earth then they began to Mount wp towards Heaven, and in the passage she felt more and More of a heavenly joy, be $<\mathrm{e}>$ ing ravished with the delectable society of her guardians, and with the full assurance of glory,[.]

At last they arived at the gates of that glorious and Imperial City of the heavenly Jerusalem,[.] Then makeing a pause, she says, but here I must stop, no tongue can tell no heart can conceave, Eare hath not heard $\& \mathrm{c}^{13}$ the Glory of that place so that I can give no Idea, nor raise any true and just representation of it in your Mindes all I can doe is to referr yow to the description of it given by John the Divine in the 21 chapter of his revelations from the $10^{\text {th }}$ and dounward where it is called a City with great and glorious walls, the nearest resemblance of it I know,[.] Only tho it is called a City it is not really and propperly so, but like unto a City with walls high great and glorious and with many gates in at one of whose gates she said she entred being guarded by the two angels,[.] When she was there the place was all Glorious in the Midle whereof she saw visibly and really that Innumerable Company of Angels and glorified spirits of just men Made perfect ${ }^{14}$ all praiseing the Redeemer and in the Midst of that glorious Assembly she saw a Glorious hy Throne and the Glorious Redeemer the Man Christ Jesus really and personally sitting thereon, the brightness of whose glory was so great, that for severall Minutes she was not able to look wpon him, but afterwards she did with unspeakable joy,[.] She said that he was there judgeing all persons that dyed wpon the Earth both Righteous and Wicked, whose souls after death were immediatly sisted befor his throne and that the judgement of each person was dispatch'd in ane instant,[.] She heard the judge Call wpon every person particularly by Name and Sirname the Righteous Came attended with angels unto whom the judge said Come, and with a wave of his right hand they passed to

13 Cor. 2:9.

14 Heb. 12:23. 
that side and were placed there[.] The wicked appearing all black and ugly and full of horror when they were sisted before the thron the judge said to them Depart and with a wave of his left hand they were driven to the gates which made them utter fearfull shricks and howlings and from thence they were taken and Convey'd by Devils to the place of punishment,[.]

She Observed that some of her acquaintances who had dyed after her, and had Come in after her were judged befor her for she heard the judge Call upon them by Name, which made her inquire at her guardian particularly that one who addressed her with such kyndness and tenderness, What may be the reason that the judge Calls not wpon me seing some who have come here after me are judged befor me; He answeres, haveing it as it seems by revelation yow are Not to be judged at this time yow must again return to the Earth and undergo a Course of sufferings but be faithfull unto the death and yow shall inherit this Croun of life ${ }^{15}$ and take $<$ this $>$ what yow have mett with as a pledge and earnest of your futur glory;[.] With that she felt as it were a weight pressing her back to the gates, and when she Came there with a greater swiftness then befor she being alwayes attended by her two guardians returned to this Earth[.] Sayes she I came to this house I saw all the people in the family I observed their business I came to the room where My body was lying $\mathrm{I}<$.> saw my body and my husband sitting by it, and when I looked upon it I had this Murnifull and Melancholy reflection, Must I again reenter, that dead stinking Carcass wherein I have sinned and suffred so much and heaveing entred into the body I found life blood spirits and warmth to spring through all $<\ldots>$ organs.

she desired the Minister to subscribe this written Narrative haveing first done it her self and desired him to Comunicat the same to some few of the Ministers of London, whom she named but only to read it to them without allowing them a Coppy, which was done and if I right remember Mr Robert Fleeming junior was present when it was read and was the Man who wrote ane account of this passage in a Letter to $\mathrm{Mr}$ James Webster, who told the story to Mr James Grierson lately ordaind Minister in

15 James $1: 12$. 
Tingwall in Zetland my intimat freind and Comerad who was My Author,[.] ${ }^{16} \mathrm{Mr}$ Webster referred him or any to whom he should tell it to Mr Thomas Davidsone present Lecturer in the Tron Church of Edinburgh in order to further information, unto whom I went and he reported it exactly as I had heard it from Mr Grierson, only with this variation, viz that she should have used the Apostle Pauls words, whether in the body or out of the body I know not. ${ }^{17}$ I am Yours

16 Robert Fleming junior was the son of the Robert Fleming who authored The Fulfilling of the Scripture. He supplied material to Wodrow on more than one occasion. He had settled in London as a minister in 1698, and was still there in 1707. He died in 1716. Scott, Fasti, vi, 489-90. James Webster was born 1658/9, and worked as a minister in Libberton, Whitekirk and Tolbooth; he died in 1720 . He was a minister who was particularly alert to the evils of atheism, being involved in the prosecution of both Aikenhead and Simson, and working as a censor of theological books. Scott, Fasti, i, 123; Michael F. Graham, The Blasphemies of Thomas Aikenhead: Boundaries of Belief on the Eve of the Enlightenment (Edinburgh, 2008), 121; Andrew Landale Drummond and James Bulloch, The Scottish Church, 1688-1843: The Age of the Moderates (Edinburgh, 1973), 32. James Grierson was born c. 1676, ordained 18 Sept. 1706, and died in 1747. Scott, Fasti, vii, 291.

17 Thomas Davidson was born in Glasgow in 1676, and elected sole lecturer in the Tron Church in 1706. He died in 1760. Scott, Fasti, vi, 316. 2 Cor. 12:3. 


\section{Bibliography}

\section{Manuscript Sources}

National Archives of the UK

PROB 11/431/438

PROB 11/464/369

National Library of Scotland

MS. 10785-6

Ry.II.c. 26

Wod.Anal

Wod.Fol.XXVIII 4846,

fos. $222-225$

Wod.Lett.Qu.II, fo.143

Wod.Lett.Qu.XIX, fos. 283-284

National Records of Scotland

CH12/12/195

$\mathrm{CH} 12 / 12 / 224$
Will of Dawbeny Turbervill, 14 May 1696.

Will of Mary Turbervill, 13 May 1702.

Elizabeth Steuart-Barclay, papers on the Laird of Coul's Ghost, 1788-1802.

Materials on Mary MacKinnon collected by James Maidment, 1823.

Robert Wodrow's Analecta, 1701-34.

James Cowan to Robert Wodrow, [1707].

James Cowan to Robert Wodrow, 26 Apr. 1710. Thomas Mack to Robert Wodrow, 15 Feb. 1723.

Ghost story from Westphalia.

Account of the Laird of Coul's ghost (William Ogilvie's version). 
CH12/12/755

CH12/12/1823

$\mathrm{CH} 12 / 16 / 251$

CH12/21/10

GD24/5/121

GD24/5/122

GD124/15/1181

GD124/15/1263

GD248/170/3

GD377/448

GD385/143
Account of the Laird of Coul's ghost (William Sinclair's version), 12 Dec. 1723.

Alexander Rose to Archibald Campbell, 28 June 1711.

Account of the Laird of Coul's ghost (William Sinclair's version), 12 Feb. 1723.

George Innes, The Primitive Doctrine: A Middle State of Happiness or Misery between Death and the Resurrection, n.d.

Wilfred Fazakerly to Lady Douglas, 1799.

Steven Widcumb to Lady Douglas, [1799].

Robert Barclay to Lord Grange, 28 Feb. 1718.

Lord Grange, Account of the Highlanders and Highlands of Scotland, 29 Dec. 1724- 2 June 1725 .

Colin Mackenzie to [the laird of Grant?], 21 July 1720 .

Thomas Rattray, account of the Ghost Dog of Mause, 31 Dec. 1730.

Assorted materials related to the Ghost Dog of Mause.

Special Collections, University of St Andrews

MS Dep. 19/14/1

Thomas Rattray, letter on the intermediate state, n.d. 


\section{Newspapers and Periodicals}

A. B., 'Story of an Apparition', Blackwood's Edinburgh Magazine, Sept. 1818, 7057.

'The Abstract of the Trial of Helen Watt and William Keith, Continued', Scots Magazine, Dec. 1766, 625-7.

'Account of a Ghost, from the Relation of a Clergyman to Whom it Appeared', Edinburgh Magazine, or Literary Miscellany, June 1786, 441-4.

'Account of an Apparition in France', Aberdeen Magazine, 9 Apr. 1789, 194-5.

Anon. to the Weekly Magazine, or Edinburgh Amusement, 10 Mar. 1774, 335-7.

Blair, A. to the Weekly Magazine, or Edinburgh Amusement, 4 Feb. 1773, 169-71.

C. G. to the Weekly Magazine, or Edinburgh Amusement, 16 Apr. 1772, 74-5. to the Weekly Magazine, or Edinburgh Amusement, 23 July 1772, 97-9.

Chambers, Robert, 'Traditions of the Celebrated Major Weir', Edinburgh Literary Journal, 11 Apr. 1829, 307-8.

Cham-pi-pi the Son in the Ghost, 19 June 1796, 77-80.

'A Chapter on Goblins', Blackwood's Edinburgh Magazine, Dec. 1823, 639-46.

'A Conversation on Female Accomplishments', Edinburgh Magazine, or Literary Miscellany, May 1796, 360-5.

'Curious Observations on the Sepulchral Lamps of the Romans', Edinburgh Magazine, Dec. 1759, 635-8.

'The Devil's Elixir', Blackwood's Edinburgh Magazine, July 1824, 55-67.

'Discovery of a Murderer', Scots Magazine, Sept. 1779, 484. 
‘A Dream', Scots Magazine, Dec. 1779, 650.

E., 'Border Sketches No. II', Edinburgh Magazine and Literary Miscellany, Oct. $1817,236-9$.

'Entertaining Story of a Sleep-Walker', Edinburgh Magazine, June 1761, 294-7.

Fabricius to the Weekly Magazine, or Edinburgh Amusement, 7 May 1772, 167-8.

Fanaticus, 'A Terrible Apparition', Weekly Magazine, or Edinburgh Amusement, 8 Sept. 1774, 330 .

Fergusson, Robert, 'The Ghaists: A Kirk-Yard Eclogue', Weekly Magazine, or Edinburgh Amusement, 27 May 1773, 275-6.

Feriatus to the Trifler, 21 May 1796, 199-206.

'From Mist's Weekly Journal, Sept. 3.', Caledonian Mercury, 12 Sept. 1726, 611112.

Gallovidiensis, 'Elegy to the Memory of Miss Dick', Edinburgh Magazine, or Literary Miscellany, Apr. 1796, 303-4.

'The Genius of Caledonia: A Poem on the Threatened French Invasion', Edinburgh Magazine, or Literary Amusement, June 1798, 464-5.

'The Ghost of the Oratory', Blackwood's Edinburgh Magazine, Oct. 1825, 433-58.

Ghost of Voltaire to the Ghost, 30 July 1796, 5-8.

Hogg, James, ‘The Bogle', Edinburgh Literary Journal, Mar. 1831, 171-2.

—, 'The Mysterious Bride', Blackwood's Edinburgh Magazine, Dec. 1830, 943-50.

'The Horrors and Torment of an Evil Conscience; and the Effects of a Disturbed Imagination', Weekly Magazine, or Edinburgh Amusement, 24 Oct. 1770, 97102. 
M., 'Robert and Margaret: A Ballad', Weekly Magazine, or Edinburgh Amusement, 1 Feb. 1776, 178.

M. to the Weekly Magazine, or Edinburgh Amusement, 6 Feb. 1772, 165-7.

M. to the Weekly Magazine, or Edinburgh Amusement, 24 Mar. 1774, 391-2.

MacKenzie, Mr, 'Epilogue to Vimonda', Universal Magazine, Sept. 1787, 155.

Maw-Worm, Richard in the Trifler, 4 July 1796, 1797 enlarged edn, 192-3.

McC, J., 'Speech Delivered in the Pantheon', Edinburgh Eighth-Day Magazine, 13 Nov. 1779, 299-301.

[Melvill, Thomas] 'T. M.', 'An Essay on Dreaming; Or, the State of the Mind in Sleep', Scots Magazine, Sept. 1749, 442-6.

Moropolemius to the Trifler, 4 July 1796, 1797 enlarged edn, 186-92.

N. A. to the Weekly Magazine, or Edinburgh Amusement, 27 Feb. 1772, 262-4.

Neanias to the Weekly Magazine, or Edinburgh Amusement, 23 July 1772, 103-5.

'Observations on Gothic Superstition', Edinburgh Magazine, or Literary Miscellany, Feb. 1799, 115-18.

'Observations on the Frenzy of Tasso, Collins, and Chatterton', Edinburgh Magazine, or Literary Miscellany, Feb. 1799, 108-12.

'On the Ancient and Modern Use of Ghosts', Edinburgh Magazine, or Literary Miscellany, Feb. 1800, 108-11.

Palemon to the Weekly Magazine, or Edinburgh Amusement, 5 Dec. 1771, 296-7.

to the Weekly Magazine, or Edinburgh Amusement, 9 July 1772, 45-6.

'Phantasmagoriana', Blackwood's Edinburgh Magazine, Aug. 1818, 589-96. 
Phantom, Felix in the Ghost, 25 Apr. 1796, 1-4.

in the Ghost, 2 May 1796, 9-12.

in the Ghost, 18 May 1796, 29-32.

in the Ghost, 27 Aug. 1796, 37-40.

Philanthropist to the Weekly Magazine, or Edinburgh Amusement, 7 July 1774, 40-2.

Philaretes to the Weekly Magazine, or Edinburgh Amusement, 11 Apr. 1771, 33-9.

— to the Weekly Magazine, or Edinburgh Amusement, 19 Dec. 1771, 355-7.

— to the Weekly Magazine, or Edinburgh Amusement, 27 Feb. 1772, 261-2.

'Poetry', Aberdeen Magazine, Literary Chronicle, and Review, 31 Dec. 1789, 853-4.

Rattle, Toby to the Weekly Magazine, or Edinburgh Amusement, 28 May 1772, 269.

'Remarks on an Argument in Favour of the Reality of Spectral Appearances', Edinburgh Magazine, or Literary Miscellany, Nov. 1794, 367-70.

Rentfree, Thomas to the Edinburgh Magazine, or Literary Miscellany, May 1786, 292-6.

Sincerus to the Weekly Magazine, or Edinburgh Amusement, 8 Sept. 1774, 327-9.

‘Singular Ghost Story’, Aberdeen Magazine, Feb. 1832, 89-94.

'Sketches of Superstitions', Chambers's Edinburgh Journal, 10 Apr. 1841, 94-5.

'A Sketch of Scotch Diablerie in General', Fraser's Magazine for Town and Country, Mar. 1842, 317-31.

Sylvander, 'Directions for Making a Modern Wit', Weekly Magazine, or Edinburgh Amusement, 23 July 1772, 113-14.

'Traditions of the Western Highlands, No. III', London Literary Gazette, 20 Mar. 
1824, 189-90.

'The Voyages and Travels of Columbus Secundus', Blackwood's Edinburgh Magazine, Nov. 1821, 389-405.

Wesley, John, 'A Strange Account', Arminian Magazine, July-Aug. 1785, 378-81, 416-20.

'Winter', Universal Magazine of Knowledge and Pleasure, Jan. 1770, 43.

Wiseman, Will to the Weekly Magazine, or Edinburgh Amusement, 9 May 1771, 1656.

‘The Wish: A Song', Weekly Magazine, or Edinburgh Amusement, 24 May 1770, 242.

Z., 'Concluding Particulars of the Life of James Hogg, the Ettrick Shepherd', Scots Magazine and Edinburgh Literary Miscellany, Nov. 1805, 820-3.

\section{Printed Primary Sources}

Abercrombie, John, Inquiries Concerning the Intellectual Powers and the Investigation of Truth, 2nd edn (Edinburgh, 1830).

An Abstract of the Bloody Massacre in Ireland ([Scotland?], [1700?]).

An Account of a Most Horrid and Barbarous Murther and Robbery, Committed on the Body of Captain Brown (Edinburgh, 1694).

An Account of a Most Horrid, Bloody, and Terrible Apparition, Which Lately Appeared in the Parish of Shotts (London, [1793?]).

An Account of a Wonderful Prodigy Seen in the Air ([Edinburgh?], 1722).

An Account of Some Imaginary Apparitions, The Effects of Fear or Fraud (Dunbar, 
[1792?]).

A Account of Some Strange Apparitions Had by a Godly Man in Kintyre, Who Hath Been Blind Six Years ([Edinburgh?], 1734).

An Account of Terrible Apparitions and Prodigies (Glasgow, 1721).

An Account of the Apparition of the Late Lord Kilmarnock (London, 1747).

Allardyce, Alexander (ed.), Letters from and to Charles Kirkpatrick Sharpe, 2 vols. (Edinburgh, 1888).

A. M., Remarks on Revelation \& Infidelity: Being the Substance of Several Speeches Lately Delivered in a Private Literary Society in Edinburgh (Edinburgh, 1797).

Amour, Jean Matthias D', Memoirs of Mr. Matthias d'Amour, ed. Paul Rodgers (London, 1836).

Anderson, John, 'United Parishes of Stronsay and Eday', in John Sinclair (ed.), The Statistical Account of Scotland, 1791-1799, electronic edn, 21 vols. (University of Edinburgh, University of Glasgow, 1999), xv, http://stat-accscot.edina.ac.uk/link/1791-99/Orkney/Stronsay\%20and\%20Eday, accessed 1 Aug. 2015.

Annand, William, Pater Noster, Our Father, Or, The Lord's Prayer Explained the Sense Thereof and Duties Therein from Scripture, History, and Fathers (Edinburgh, 1670).

An Antidote to Superstition: Or, A Cure for Those Weak Minds Which Are Troubled with the Fear of Ghosts, Witches \&c. (Dunbar, [1803?]).

The Antiquated Usages, Which Have Made so Great a Noise amongst Us, Briefly Examined, and Found Insufficient (Edinburgh, 1728).

The Apparition (Edinburgh, 1727). 
Aquinas, Thomas, Summa Theologica, trans. Fathers of the English Dominican Province (New York, 1947).

Aubrey, John, Miscellanies (London, 1696).

Baillie, Joanna, 'Night Scenes of Other Times', Poems: Wherein It Is Attempted to Describe Certain Views of Nature and of Rustic Manners (London, 1790).

— , 'To Fear', Poems: Wherein It Is Attempted to Describe Certain Views of Nature and of Rustic Manners (London, 1790).

—, 'To the Reader', A Series of Plays, in Which It Is Attempted to Delineate the Stronger Passions of the Mind, 3 vols. (London, 1812).

Baillie, Robert, Letters and Journals of Robert Baillie, A. M., ed. David Laing, 3 vols. (Edinburgh, 1841-2).

Bannatyne, George, The Bannatyne Manuscript, ed. W. Tod Ritchie (Edinburgh, 1928-34).

Bannatyne, Richard, Memorials of Transactions in Scotland, 1569-1573, ed. Robert Pitcairn (Edinburgh, 1836).

Baxter, Richard, The Certainty of the World of Spirits, and Consequently, of the Immortality of Souls of the Malice and Misery of the Devils and the Damned (London, 1691).

Beattie, James, Elements of Moral Science, 2 vols. (Edinburgh, 1790-3).

— Original Poems and Translations (London, 1760).

Bell, Andrew, 'Parish of Roxburgh', in John Sinclair (ed.), The Statistical Account of Scotland, 1791-1799, electronic edn, 21 vols. (University of Edinburgh, University of Glasgow, 1999), xix, http://stat-acc-scot.edina.ac.uk/link/179199/Roxburgh/Roxburgh, accessed 1 Aug. 2015.

Bell, Thomas, Grapes in the Wilderness: Or, A Discourse of the Dispensations of 
God towards His People (Glasgow, 1705).

—- Nehemiah the Tirshatha, Or, The Character of a Good Commissioner to Which Is Added Grapes in the Wilderness (Edinburgh, 1692).

B.G., The Relation of a Strange Apparition in the Air, on the 19. Day of August, 1653 ([Edinburgh?], 1654).

Birnie, William, The Blame of Kirk-Buriall, Tending to Perswade Cemiteriall Civilitie (Edinburgh, 1606, STC 3089).

Blacklock, Thomas, Poems by the Late Reverend Dr. Thomas Blacklock (Edinburgh, 1793).

Blair, Hugh, A Critical Dissertation on the Poems of Ossian (London, 1763).

Blair, Robert, The Grave: A Poem (London, 1743).

Blair, Robert, The Life of Mr. Robert Blair, ed. T. M'Crie (Edinburgh, 1848).

Boethius, Hector, Scotorum Historia, ed. Dana F. Sutton, electronic edn (University of Birmingham, 2010), http://www.philological.bham.ac.uk/boece, accessed 1 Aug. 2015.

Bonny Jean: To Which Are Added, Tweedside, Although My Meg's Gi'en Me the Bag, Samuel Macaree’s Ghaist (Stirling, 1824).

Bovet, Richard, Pandoemonium, or the Devil's Cloyster, Being a Further Blow to Modern Sadduceism (London, 1684).

Boyd, Zacharie, The Last Battell of the Soule in Death (Edinburgh, 1628, STC 3446a.5).

Brand, John, A Brief Description of Orkney, Zetland, Pightland-Firth \& Caithness (Edinburgh, 1701).

Brand, John, Observations on Popular Antiquities (Newcastle, 1777). 
Brewster, David, Letters on Natural Magic, Addressed to Sir Walter Scott (London, 1832).

Brissot's Ghost! Or, Intelligence from the Other World (Edinburgh, 1794).

Brown, John, Quakerisme the Path-Way to Paganisme (Edinburgh, 1678).

Brown, William, Impiety and Superstition Expos'd: A Poetical Essay (Edinburgh, 1710).

Brutal Assault and Murder! ([Scotland?], 1830).

Buchanan, George, Rerum Scoticarum Historia, ed. Dana F. Sutton, electronic edn (University of Birmingham, 2009), http://www.philological.bham.ac.uk/ scothist, accessed 1 Aug. 2015.

Buchan, Peter, Ancient Ballads and Songs of the North of Scotland, 2 vols. (Edinburgh, 1828).

Burness, John, 'Thrummy Cap', Plays, Poems, Tales and Other Pieces (Montrose, 1819).

Burns, Robert, Poems, Chiefly in the Scottish Dialect (Kilmarnock, 1786).

—, Poems, Chiefly in the Scottish Dialect (Edinburgh, 1787).

Burt, Edmund, Letters from a Gentleman in the North of Scotland, 2 vols. (London, 1754).

Burton, Robert, The Anatomy of Melancholy (Oxford, 1621, STC 4159).

Calvin, John, Calvin: Commentaries, ed. Joseph Haroutunian (London, 1958).

—, Calvin's Institutes: A New Compend, ed. Hugh T. Kerr (Louisville, 1989).

—_, 'L'Excuse à Messieurs les Nicodémites', Traité des Reliques, Suivi de l'Excuse à Messieurs les Nicodémites (Paris, 1921). 
—, 'Psychopannychia', in Thomas F. Torrance (ed.), Tracts and Treatises in Defense of the Reformed Faith, 3 vols. (Grand Rapids, 1958), iii.

Campbell, Archibald, A Discourse Proving That the Apostles Were No Enthusiasts (London, 1730).

Campbell, Archibald, The Doctrines of a Middle State between Death and the Resurrection (London, 1721).

Campbell, Daniel, Meditations on Eternity (Glasgow, 1721).

Campbell, George, A Dissertation on Miracles (Edinburgh, 1762).

Campbell, Ninian, A Treatise upon Death (Edinburgh, 1635, STC 4533).

Captain Mulligan: Miss Bailey’s Ghost (Stirling, [1813-20?]).

Chambers, Robert, The Book of Days, A Miscellany of Popular Antiquities (London, 1863-4).

- Illustrations of the Author of Waverley: Being Notices and Anecdotes of Real Characters, Scenes, and Incidents, Supposed to Be Described in His Works, 2nd edn (Edinburgh, 1825).

- The Picture of Scotland, 2 vols. (Edinburgh, 1827).

- The Scottish Ballads (Edinburgh, 1829).

$\longrightarrow$, Traditions of Edinburgh (Edinburgh, 1824).

$\longrightarrow$, Traditions of Edinburgh, revised edn (London, 1868).

Cheyn, William, The Great Danger and Vanity or Folly of Atheism Discovered in a Dialogue between an Atheist and a Believer (Edinburgh, 1720).

Child, Francis James, The English and Scottish Popular Ballads, 5 vols. (Boston, 1882-98). 
C. N., A Counsel of Criminal Ghosts to the Ghost of the Great Beilhaven (Edinburgh, 1729).

Cochrane, Arthur C. (ed.), 'The Scottish Confession of Faith, 1560', Reformed Confessions of the Sixteenth Century (Philadelphia, 1966).

Cockburn, William, The Being of God Proved from the Universal Voice of Conscience (Edinburgh, 1726).

Collins, William, An Ode on the Popular Superstitions of the Highlands of Scotland (London, 1788).

Combe, George, A System of Phrenology, 3rd edn (Edinburgh, 1830).

The Compleat Wizzard: Being a Collection of Authentic and Entertaining Narratives of the Real Existence and Appearance of Ghosts, Demons, and Spectres (London, 1770).

Copland, John, Saint Andrews: Or, a Sentimental Evening Walk near the Ruins of That Ancient City (Edinburgh, 1776).

Crawford, William, The Works of the Truly Pious and Learned Mr. William Crawford Late Minister of the Gospel at Wilton, 2 vols. (Edinburgh, 1748).

- Zion's Traveller: Or, the Soul's Progress to Heaven, 2nd edn (Edinburgh, 1743).

Crowe, Catherine, The Night Side of Nature, or Ghosts and Ghost Seers, 2 vols. (London, 1848).

Cunningham, Allan, Traditional Tales of the English and Scottish Peasantry, 2 vols. (London, 1822).

Dalyell, John Graham, The Darker Superstitions of Scotland: Illustrated from History and Practice (Edinburgh, 1834).

Davies, Owen (ed.), Ghosts: A Social History, 5 vols. (London, 2010). 
Defoe, Daniel, An Essay on the History and Reality of Apparitions (London, 1728).

—, A Tour Through the Whole Island of Great Britain, eds. P. N. Furbank, W. R. Owens, and A. J. Coulson (New Haven, 1991).

Denniston, James, Legends of Galloway: Being a Series of Traditions, Illustrative of Its Ancient History, Customs, Manners, and Superstitions (Edinburgh, 1825).

Douglas, Gavin, The Aeneid (1513), ed. Gordon Kendal (London, 2011).

A Dreadful Example for Wicked Husbands: Or the Virtuous Wife in Distress ([Edinburgh?], [1799?]).

Drummond, William, Flowres of Sion ([Edinburgh], 1623, STC 7247).

Drummond, William, Poems: By William Drummond, of Hawthorne-Denne (Edinburgh, 1616, STC 7255).

Duff, William, An Essay on Original Genius; and Its Various Modes of Exertion in Philosophy and the Fine Arts, Particularly in Poetry (London, 1767).

Dunbar, William, 'Apon the Midsummer Evin, Mirriest of Nichtis (The Tretis Of The Twa Mariit Wemen and the Wedo)', in Jacqueline Tasioulas (ed.), The Makars: The Poems of Henryson, Dunbar and Douglas (Edinburgh, 1999).

—, 'Of Sir Thomas Norray', in David Laing (ed.), The Poems of William Dunbar, 2 vols. (Edinburgh, 1834), i.

— , 'Schir Johine the Ros, Ane Thing Thair Is Compild (The Flyting of Dumbar and Kennedie)', in Jacqueline Tasioulas (ed.), The Makars: The Poems of Henryson, Dunbar and Douglas (Edinburgh, 1999).

Dundass, James, An Impartial Enquiry into the Rise and Progress of the Ancient Usage of Prayers for the Dead (Edinburgh, 1743).

Durham, James, The Blessedness of the Death of Those That Die in the Lord (Glasgow, 1756). 
—, A Commentarie upon the Book of the Revelation (Edinburgh, 1658).

The Edinburgh Medley of Entertainment, 2 vols. (Edinburgh, 1800).

Edmondaton, Laurence, 'General Observations on the County of Shetland', The New Statistical Account of Scotland, 1834-45, electronic edn, 15 vols. (University of Edinburgh, University of Glasgow, 1999), xv, http://stat-accscot.edina.ac.uk/link/1834-45/Shetland/General\%20Observations, accessed 1 Aug. 2015.

Encyclopcedia Britannica; Or, a Dictionary of Arts, Sciences, \&c., 2nd edn, 10 vols. (Edinburgh, 1778-83).

Encyclopcedia Britannica; Or, a Dictionary of Arts, Sciences, and Miscellaneous Literature, 3rd edn, 20 vols. (Edinburgh, 1797).

Erskine, Ralph, The Happy Congregation: Or, the Great Gathering of the People to Shiloh (Edinburgh, 1726).

Erskine, William, Epistle from Lady Grange to Edward D-, Esq. (London, 1798).

Faggot, Robbin, The Ghaist: A Poem (Glasgow, 1810).

Ferguson, Adam, Principles of Moral and Political Science, 2 vols. (Edinburgh, 1792).

Fergusson, Alexander, The Honourable Henry Erskine, Lord Advocate for Scotland (Edinburgh, 1882).

Ferriar, John, An Essay Towards a Theory of Apparitions (London, 1813).

Fleming, Robert, The Fulfilling of the Scripture, in Three Parts, reprint of 1681 3rd edn, 2 vols. (Glasgow, 1801).

Fordyce, James, A Collection of Hymns and Sacred Poems (Aberdeen, 1787).

Fraser, John, 'Deuteroskopia', in Michael Hunter, The Occult Laboratory: Magic, 
Science, and Second Sight in Late Seventeenth-Century Scotland (Woodbridge, 2001).

A Full True and Particular Account of the Most Dreadful Apparrition: Of Robert Watt Wine-Merchant in Edinr, Who Appeared to James Macdonald Plaisterer in Lieth-Walk ([Edinburgh?], [1794?]).

Garden, James, 'Letters from Dr. Ja. Garden, Professor of Theologie at Aberdene to Mr J. Aubrey Concerning the Druid's Temples', in Michael Hunter (ed.), The Occult Laboratory: Magic, Science, and Second Sight in Late SeventeenthCentury Scotland (Woodbridge, 2001).

Gellatly, David, Relief Procedure Justly Exhibited (Edinburgh, 1794).

Gentlemen of the Seagate Congregation, A True Narrative of the Case between the Episcopal Congregation of the Seagate of Dundee, on the One Part; and Bishop Raitt with the Reverend Mr. William Robertson, on the Other (Edinburgh, 1745).

Gerard, Alexander, An Essay on Taste (London, 1759).

Ghosts, \&c! (Edinburgh, 1827).

Glanvill, Joseph, Saducismus Triumphatus (London, 1681).

The Glasgow Miscellany, Or, Amusing Companion, 2 vols. (Glasgow, 1800).

Glas, John, A View of the Heresy of Aerius (Edinburgh, 1745).

Gordon, Patrick, The Famous History of the Renown'd and Valiant Prince, Robert Sirnamed, the Bruce, King of Scotland, \&c (Edinburgh, 1718).

The Gosford Tragedy: Or the Perjured Carpenter ([Edinburgh?], 1775).

Graeme, James, Poems on Several Occasions (Edinburgh, 1773).

Grant, Anne MacVicar, Essays on the Superstitions of the Highlanders of Scotland, 2 
vols. (London, 1811).

Grant, John, 'Parish of Kirkmichael', in John Sinclair (ed.), The Statistical Account of Scotland, 1791-1799, electronic edn, 21 vols. (University of Edinburgh, University of Glasgow, 1999), xii, http://stat-acc-scot.edina.ac.uk/link/179199/Banff/Kirkmichael, accessed 1 Aug. 2015.

Gregor, Walter, Notes on the Folk-Lore of the North-East of Scotland (London, 1881).

Grose, Francis, The Antiquities of Scotland, 2 vols. (London, 1797).

Guild, William, An Answer to a Popish Pamphlet Called The Touch-Stone of the Reformed Gospell (Aberdeen, 1656).

$\longrightarrow$, Anti-Christ Pointed and Painted Out in His True Colours (Aberdeen, 1655).

Halyburton, Thomas, Natural Religion Insufficient, and Reveal'd Necessary to Man's Happiness in His Present State (Edinburgh, 1714).

Hare's Dream! Describing the Apparition of Burke and Others, Which Appeared to Him While in the Calton Jail ([Edinburgh], [1829]).

Harley, William, 'The Mentor', The Asylum or Weekly Miscellany, 3 vols. (Glasgow, 1795-6), i, 114-274.

Hary, The Wallace: Selections, ed. Anne McKim, electronic edn (Medieval Institute Publications, 2003), http://d.lib.rochester.edu/teams/publication/mckim-thewallace-selections, accessed 1 Aug. 2015.

Hibbert, Samuel, Sketches of the Philosophy of Apparitions: Or, An Attempt to Trace Such Illusions to Their Physical Causes, 2nd edn (Edinburgh, 1825).

The Historical Tragedy, of Young Beateman's Ghost, or The Perjured Maid, Justly Rewarded ([Edinburgh], [1778?]).

The History of Witches, Ghosts, and Highland Seers (Berwick, [1775?]). 
Hogg, James, The Brownie of Bodsbeck, and Other Tales, 2 vols. (Edinburgh, 1818).

—, The Private Memoirs and Confessions of a Justified Sinner, ed. Adrian Hunter (Peterborough [Ont.], 2001).

- The Three Perils of Man: Or, War, Women, and Witchcraft, 3 vols. (London, 1822).

— Winter Evening Tales, ed. Ian Duncan (Edinburgh, 2004).

Howell, Thomas Jones, and William Cobbett, A Complete Collection of State Trials and Proceedings for High Treason and Other Crimes and Misdemeanors from the Earliest Period to the Year 1783, with Notes and Other Illustrations, 21 vols. (London, 1816).

Hume, David, 'An Enquiry Concerning Human Understanding', in Mark C. Rooks (ed.), The Complete Works and Correspondence of David Hume, electronic edn (Charlottesville, 1995), http://pm.nlx.com/xtf/view?docId=hume/hume. 00.xml;chunk.id=div.hume.pmpreface. 1 ;toc.depth=2;toc.id=div.hume.pmpref ace.1; hit.rank=0; brand=default, accessed 1 Aug. 2015.

—., 'Scotticisms', The Philosophical Works of David Hume, 4 vols. (Edinburgh, 1826), i.

Hutcheson, Francis, A System of Moral Philosophy, in Three Books, 2 vols. (Glasgow, 1755).

Innes, George, Fourteen Discourses on Practical Subjects (London, 1783).

Insulanus, Theophilus, A Treatise on the Second Sight, Dreams and Apparitions (Edinburgh, 1763).

Irvine, Christopher, Medicina Magnetica: Or, the Rare and Wonderful Art of Curing by Sympathy ([Edinburgh], 1656).

Jackson, John, The History of the Scottish Stage, from Its First Establishment to the 
Present Time (Edinburgh, 1793).

James VI, 'Daemonologie, in Forme of Ane Dialogue', in James Craigie and Alexander Law (eds.), Minor Prose Works of King James VI and I (Edinburgh, 1982).

Johnson, Samuel, A Journey to the Western Islands of Scotland (London, 1775).

Johnstone, A., 'Parish of Monquhitter: Additional Communications', in John Sinclair (ed.), The Statistical Account of Scotland, 1791-1799, electronic edn, 21 vols. (University of Edinburgh, University of Glasgow, 1999), xxi, http://stat-accscot.edina.ac.uk/link/1791-99/General\%20Appendixgen\%20App \%20Vol6/21/138, accessed 1 Aug. 2015.

Kames, Henry Home, Essays on the Principles of Morality and Natural Religion (Edinburgh, 1751).

Keith, Peter, The Ghaist O' Fearnden; Auld Poumire; and Rob Man; Three Tales ([Brechin?], 1834).

The Kentshire Tragedy, Or, The Constant Lovers Overtbrow ([Edinburgh?], 1794).

Kerr, Charles, Juvenile Performances in Poetry (Edinburgh, 1788).

Kirk, Robert, 'The Secret Commonwealth of Elves, Fauns \& Fairies', in Michael Hunter (ed.), The Occult Laboratory: Magic, Science, and Second Sight in Late Seventeenth-Century Scotland (Woodbridge, 2001).

Kirkton, James, The Secret and True History of the Church of Scotland: From the Restoration to the Year 1678, ed. Charles Kirkpatrick Sharpe (Edinburgh, 1817).

Knox, John, The History of the Reformation of the Church of Scotland (London, 1644).

Laing, Alexander, 'The Brownie of Fearnden', in Alexander Whitelaw (ed.), The 
Book of Scottish Ballads: Collected and Illustrated with Historical and Critical Notices (Glasgow, 1845).

Laskaya, Anne and Eve Salisbury (eds.), 'Sir Orfeo', The Middle English Breton Lays, electronic edn (Medieval Institute Publications, 1995), http://d.lib.rochester.edu/teams/publication/laskaya-and-salisbury-middleenglish-breton-lays, accessed 1 Aug. 2015.

Lauder, John (ed.), The Decisions of the Lords of Council and Session, from June 6th, 1678, to July 30th, 1712, 2 vols. (Edinburgh, 1759-61).

Lavater, Ludwig, Of Ghostes and Spirites Walking by Nyght, trans. Robert Harrison (London, 1572, STC 15320).

Law, Robert, Memorialls: Or the Memorable Things That Fell out Within This Island of Brittain from 1638 to 1684, ed. Charles Kirkpatrick Sharpe (Edinburgh, 1818).

The Leverpool Tragedy or the Perjur'd Sailor ([Glasgow?], 1767).

Lewis, Gregory, The Monk: A Romance, 3 vols. (Waterford, 1796).

Lindsay, David, The Poetical Works of Sir David Lyndsay, ed. David Laing, 3 vols. (Edinburgh, 1879).

Lindsay, Robert, The History of Scotland: From 21 February, 1436 to March, 1565 (Edinburgh, 1728).

Livingstone, John, 'Memorable Characteristics, and Remarkable Passages of Divine Providence', in W. K. Tweedie (ed.), Select Biographies, 2 vols. (Edinburgh, 1845), i.

Locke, John, An Essay Concerning Humane Understanding, 4th edn (London, 1700).

Lockhart, John Gibson, Memoirs of the Life of Sir Walter Scott, 2nd edn, 10 vols. (Edinburgh, 1839). 
Logan, John, Sermons by the Late Reverend John Logan, 2 vols. (Edinburgh, 1790$1)$.

Le Loyer, Pierre, A Treatise of Specters or Straunge Sights, Visions and Apparitions Appearing Sensibly Unto Men (London, 1605, STC 15448).

MacCulloch, John, The Highlands and Western Isles of Scotland, 4 vols. (London, 1824).

MacFarlane, Walter, Geographical Collections Relating to Scotland Made by Walter Macfarlane, eds. Arthur Mitchell and James Toshach Clark, 3 vols. (Edinburgh, 1906-8).

Mackail, Hugh, The Last Publick Sermon, Being a Faithful and Free One, Preached by Mr. Hugh Mackaile (Edinburgh, 1749).

Mackay, Charles, Memoirs of Extraordinary Popular Delusions, 2 vols. (London, 1841).

Mackenzie, George, The Laws and Customes of Scotland, in Matters Criminal (Edinburgh, 1678).

Mackenzie, George, Synopsis Apocalyptica: Or, a Short Plain Explication and Application of Daniel's Prophecy and of St. John's Revelation (Edinburgh, 1708).

MacKinnon's Ghost ([Edinburgh? ], [1823?]).

MacLaurin, George, 'Laura, Or, the Punishment of Perfidy', in Colin MacLaurin and George MacLaurin, The Poetical and Dramatic Works of Colin Maclaurin, Esq. Advocate, and of the Late George Maclaurin, Esq. Writer, 2 vols. (Edinburgh, 1812), i.

MacLean, Roderick, 'Parish of South Uist', The New Statistical Account of Scotland, 1834-45, electronic edn, 15 vols. (University of Edinburgh, University of Glasgow, 1999), xiv, http://stat-acc-scot.edina.ac.uk/link/1834-45/ 
Inverness/South\%20Uist, accessed 1 Aug. 2015.

Macleod, Malcolm, History of Witches \&c (London, 1793).

Macnish, Robert, The Philosophy of Sleep, 2nd edn (Glasgow, 1838).

Macpherson, James, The Works of Ossian, the Son of Fingal, 2 vols. (London, 1765).

—

Mallet, David, The Excursion: A Poem (London, 1728).

Mann, William, A Voice from the Dead, Or, The Apparition of William Clarkson (Paisley, 1826).

Margaret Dickson's Penetential Confession ([Edinburgh], [1724]).

Marjoribanks, Thomas, 'Parish of Lochmaben', The New Statistical Account of Scotland, 1834-45, electronic edn, 15 vols. (University of Edinburgh, University of Glasgow, 1999), iv, http://stat-acc-scot.edina.ac.uk/link/183445/Dumfries/Lochmaben, accessed 1 Aug. 2015.

Martin, Martin, A Description of the Western Isles of Scotland (London, 1703).

Maxwell, Herbert (trans.), The Chronicle of Lanercost, 1272-1346 (Glasgow, 1913).

McDonald, A., Vimonda: A Tragedy (Dublin, 1788).

McDonald, Mrs A., Evening Amusements, Or, What Happens in Life, a Novel, 2 vols. (Edinburgh, 1797).

McDonald, Robert, 'Parish of Blairgowrie', The New Statistical Account of Scotland, 1834-45, electronic edn, 15 vols. (University of Edinburgh, University of Glasgow, 1999), x, http://stat-acc-scot.edina.ac.uk/link/1834-45/Perth/ Blairgowrie, accessed 1 Aug. 2015.

McNaughton, Allan, 'Parish of Kilbride', The New Statistical Account of Scotland, 1834-45, electronic edn, 15 vols. (University of Edinburgh, University of 
Glasgow, 1999), v, http://stat-acc-scot.edina.ac.uk/link/1834-45/Bute/ Kilbride, accessed 1 Aug. 2015.

McQueen, John, 'Parish of Applecross', in John Sinclair (ed.), The Statistical Account of Scotland, 1791-1799, electronic edn, 21 vols. (University of Edinburgh, University of Glasgow, 1999), iii, http://stat-acc-scot.edina. ac.uk/link/1791-99/Ross\%20and\%20Cromarty/Applecross, accessed 1 Aug. 2015.

McRitchie, William, 'Parish of Clunie', in John Sinclair (ed.), The Statistical Account of Scotland, 1791-1799, electronic edn, 21 vols. (University of Edinburgh, University of Glasgow, 1999), ix, http://stat-accscot.edina.ac.uk/link/1791-99/Perth/Clunie, accessed 1 Aug. 2015.

Merry Andrew, The Antient and New History of Buck-Haven in Fife Shire ([Edinburgh?], 1782).

La Mettrie, Julien Offray de, 'Machine Man', in Ann Thomson (ed.), La Mettrie: Machine Man and Other Writings (Cambridge, 1996).

Miller, Hugh, Scenes and Legends of the North of Scotland, or The Traditional History of Cromarty (Edinburgh, 1835).

— Scenes and Legends of the North of Scotland; Or, The Traditional History of Cromarty, 2nd edn (London, 1850).

Mitchell, James, Memoirs of the Life of James Mitchell of Dykes, in the Parish of Ardrossan (Glasgow, 1759).

Mitchell, J., and John Dickie, The Philosophy of Witchcraft (Paisley, 1839).

Moncrieff, William Thomas, The Spectre Bridegroom: Or a Ghost in Spite of Himself (London, 1821).

More, Henry, An Antidote Against Atheism (London, 1653). 
Mure, Elizabeth, 'Some Remarks on the Change of Manners in My Own Time, 1700-1790', in William Mure (ed.), Selections from the Family Papers Preserved at Caldwell, 3 vols. (Glasgow, 1854), i.

A New Vocabulary English and Latin, for the Use of Schools, 5th edn (Edinburgh, 1720).

Ogilvie, William, A Copy of Several Conferences and Meetings, \&c. That Past Betwixt the Reverend Mr. Ogilvie, Late Minister of the Gospel at Innerwick, and the Ghost of Mr. Maxwel Late Laird of Cool ([Edinburgh?], 1751).

- Copy of Several Conferences and Meetings, Giving an Account of What Past Betwixt the Reverend Mr. Ogilvie, Late Minister of the Gospel at Innerwick, and the Ghost of Mr. Maxwel, Late Laird of Cool ([Edinburgh?], [1790?]).

—, The Laird O'Coul's Ghost, ed. J. F. S. Gordon (London, 1892).

- The Laird of Cools Ghost, Being a Copy of Several Conferences and Meetings That Passed between the Reverend Mr. Ogilvie, Late Minister of the Gospel at Innerwick, in East Lothian, and the Late Laird of Cool's Ghost (Edinburgh, [1800?]).

—, The Laird of Cool's Ghost, Being, a Wonderful and True Account of Several Conferences Betwixt the Revd. Mr Ogilvie, Late Minister of the Gospel at Innerwick, and the Ghost of the Deceast Mr Maxwell, Late Laird of Cool (Dumfries, 1786).

- Narrative of Four Conferences Between the Ghost of Mr. Maxwell, of Coul, and the Rev. Mr. Ogilvie, Minister of Innerwick, ed. Elizabeth Steuart (London, 1808).

Pennant, Thomas, A Tour in Scotland 1769 (Chester, 1771).

$\longrightarrow$, A Tour in Scotland 1772, Part 1 (Chester, 1774). 
—

Person, David, Varieties: Or, A Surveigh of Rare and Excellent Matters Necessary and Delectable for All Sorts of Persons (London, 1635, STC 19781).

Picken, Andrew, Tales and Sketches of the West of Scotland (Glasgow, 1824).

Pitcairne, Archibald, The Latin Poems, eds. John MacQueen and Winifred MacQueen (Assen, 2009).

— The Phanaticks, ed. John MacQueen (Woodbridge, 2012).

Pitcairn, Robert (ed.), Criminal Trials in Scotland, 1488-1624, 4 vols. (Edinburgh, 1833).

P. M., The Speech of a Fyfe Laird, Newly Come from Grave ([Scotland], [1680?]).

Pope, Walter, The Life of the Right Reverend Father in God, Seth, Lord Bishop of Salisbury (London, 1697).

Pye, John, A True and Perfect Account of a Strange and Dreadful Apparition Which Lately Infested and Sunk a Ship Bound for New-Castle (Edinburgh, 1672).

Raitt, James, An Instructed Historical Account of the Settlement in the Episcopal Congregation of Dundee in 1727 ([Edinburgh?], 1744).

Ramsay, Allan, Elegies on Maggy Johnston, John Cowper, and Lucky Wood, 2nd edn (Edinburgh, 1718).

(ed.), The Ever Green, Being a Collection of Scots Poems, 2 vols. (Edinburgh, 1724).

- The Gentle Shepherd: A Scots Pastoral Comedy (Edinburgh, 1725).

—, A Tale of Three Bonnets ([Edinburgh?], 1722).

Rattray, Thomas, The Ancient Liturgy of the Church of Jerusalem (London, 1744). 
Robert Johnston's Ghost, Or, His Last Advice to the Gipsies, and Other Gangs of Robbers and Murderers in Scotland ([Edinburgh?], [1720?]).

Robertson, David (ed.), South Leith Records, Compiled from the Parish Registers for the Years 1588 to 1700 (Edinburgh, 1911).

Robertson, John, Rusticus Ad Clericum, Or, The Plow-Man Rebuking the Priest in Answer to Verus Patroclus ([Aberdeen?], 1694).

Saint-Fond, Barthélemy Faujas de, A Journey through England and Scotland to the Hebrides in 1784, ed. and trans. Archibald Geikie, 2 vols. (Glasgow, 1907).

Scott, Walter, 'Introduction', in Horace Walpole, The Castle of Otranto: A Gothic Story (Edinburgh, 1811).

- The Lady of the Lake: A Poem (Edinburgh, 1810).

- Letters on Demonology and Witchcraft (London, 1830).

- Marmion: A Tale of Flodden Field (Edinburgh, 1808).

- Minstrelsy of the Scottish Border, 3 vols. (Edinburgh, 1802-3).

—, The Monastery: A Romance, 3 vols. (Edinburgh, 1820).

—, 'My Aunt Margaret's Mirror', in Frédéric Mansel Reynolds (ed.), The Keepsake for 1829 (London, 1828).

- The Poetical Works of Sir Walter Scott, Bart., ed. J. G. Lockhart, 12 vols. (Edinburgh, 1833-4).

- Rokeby: A Poem (Edinburgh, 1813).

$\longrightarrow$, Tales of My Landlord, 4 vols. (Edinburgh, 1819).

—, 'The Tapestried Chamber', in Frédéric Mansel Reynolds (ed.), The Keepsake for 1829 (London, 1829). 
- (ed.), Trial of Duncan Terig Alias Clerk, and Alexander Bane Macdonald, for the Murder of Arthur Davis, Sergeant in General Guise's Regiment of Foot (Edinburgh, 1831).

- Waverley Novels, Vol. 18: The Monastery (Edinburgh, 1830).

—, Waverley Novels, Vol. 34: Redgauntlet (Edinburgh, 1832).

The Second Letter, from the Ghost of Bailie Cuthbert ([Edinburgh?], [1780?]).

Shaftsbury's Ghost to Doctor Oats: In a Vision, Concerning the Jesuits and Lords in the Tower (Edinburgh, 1683).

Sharpe, Charles Kirkpatrick, 'Prefatory Notice', in Charles Kirkpatrick Sharpe (ed.), Memorialls: Or the Memorable Things That Fell out Within This Island of Brittain from 1638 to 1684 (Edinburgh, 1818).

Shaw, Lachlan, The History of the Province of Moray (Edinburgh, 1775).

Simson, Patrick, A Short Compend of the Historie of the First Ten Persecutions Moved against Christians Divided into III. Centuries (Edinburgh, 1613, STC 23601).

Sinclair, George, Satan's Invisible World Discovered (Edinburgh, 1685).

- The Hydrostaticks, Or, The Weight, Force, and Pressure of Fluid Bodies, Made Evident by Physical, and Sensible Experiments (Edinburgh, 1672).

Skinner, John, A Course of Lectures, Delivered on the Six Sundays in Lent (Aberdeen, 1786).

Smollett, Tobias, The Adventures of Ferdinand Count Fathom, 2 vols. (London, 1753).

- The Adventures of Peregrine Pickle, 3 vols. (Dublin, 1751).

- The Adventures of Roderick Random, 2 vols. (London, 1748). 
—

- The Expedition of Humphry Clinker, 2 vols. (Dublin, 1771).

—, 'Ode to Mirth', Plays and Poems Written by T. Smollett, M. D. (London, 1777).

Some Predictions or Prophesies ... Likewise, an Account of an Apparition in the Castle of Edinburgh, in the Year 1651 or 1652 (Edinburgh, 1739).

Stewart, Dugald, Elements of the Philosophy of the Human Mind, 3 vols. (London, 1792-1827).

Stewart, William Grant, The Popular Superstitions and Festive Amusements of the Highlanders of Scotland (Edinburgh, 1823).

The St. James's Surprizing and Afrightful Apparition ([Edinburgh?], 1722).

Strange and Wonderfull Apparitions That Was Seen in the Air ([Edinburgh?], 1719).

St. Serfe, Thomas, The Remarkable Prophesies in Order to the Present Times ([Edinburgh], 1665).

Stuart, John (ed.), Extracts from the Presbytery Book of Strathbogie, A.D. 1631-1654 (Aberdeen, 1843).

- (ed.), Selections from the Records of the Kirk Session, Presbytery, and Synod of Aberdeen (Aberdeen, 1846).

Taillepied, Noel, Psichologie, ou Traité de l'Apparition des Esprits (Rouen, 1588).

Tait, John, 'The Vanity of Human Wishes, an Elegy, Occasioned by the Untimely Death of a Scots Poet', in Robert Fergusson, Poems on Various Subjects, by Robert Fergusson, Part II (Edinburgh, 1779), 149-51.

Taylor, Alexander, 'Parish of Leochel and Cushnie', The New Statistical Account of Scotland, 1834-45, electronic edn, 15 vols. (University of Edinburgh, 
University of Glasgow, 1999), xii, http://stat-acc-scot.edina.ac.uk/link/183445/Aberdeen/Leochel, accessed 1 Aug. 2015.

Telfair, Alexander, A True Relation of an Apparition, Expressions and Actings, of a Spirit (Edinburgh, 1696).

Thomson, Derick S. (ed.), Gaelic Poetry in the Eighteenth Century: A Bilingual Anthology (Aberdeen, 1993).

Thomson, Thomas, A Diurnal of Remarkable Occurrents That Have Passed within the Country of Scotland (Edinburgh, 1833).

Threipland, Stuart Moncrieff, Letters Respecting the Performances at the Theatre Royal, Edinburgh (Edinburgh, 1800).

Thrummy Cap, a Tale; and The Brownie O'Fearnden, a Ballad (Brechin, 1832).

Tod, John, 'Parish of Mauchline', The New Statistical Account of Scotland, 1834-45, electronic edn, 15 vols. (University of Edinburgh, University of Glasgow, 1999), v, http://stat-acc-scot.edina.ac.uk/link/1834-45/Ayrshire/Mauchline, accessed 1 Aug. 2015.

A True and Impartial Relation of a Wonderful Apparition That Happen'd in the Royal Camp in Flanders (Edinburgh, 1692).

The Vision of Dr Morris, Or, The Spectral Warning ([Edinburgh], 1821).

Visits from the World of Spirits, Or, Interesting Anecdotes of the Dead (London, 1791).

Walker, Patrick, Six Saints of the Covenant, ed. David Hay Fleming, 2 vols. (London, 1901).

Watson, Alexander, The Anti-Jacobin, a Hudibrastic Poem in Twenty-One Cantos (Edinburgh, 1794).

Webster, James, Select Sermons Preach'd on Several Texts (Edinburgh, 1723). 
Webster, John, The Displaying of Supposed Witchcraft (London, 1677).

Wedderburn, Alexander, Heaven upon Earth, Or, The History of the Transfiguration of Jesus Chirst Opened (Edinburgh, 1703).

Willison, John, A Fair and Impartial Testimony: Essayed in Name of a Number of Ministers, Elders, and Christian People of the Church of Scotland (Edinburgh, 1744).

—, A Treatise Concerning the Sanctifying of the Lord's Day (Edinburgh, 1716).

Wilson, John, Lights and Shadows of Scottish Life (Edinburgh, 1822).

Wilson, John Mackay, Wilson's Tales of the Borders: A Selection, ed. T. Henderson (Edinburgh, 1934).

Wodrow, Robert, Analecta: Or Materials for a History of Remarkable Providences Mostly Relating to Scotch Ministers and Christians, ed. Matthew Leishman, 4 vols. (1842-3).

- The Correspondence of the Rev. Robert Wodrow, ed. Thomas M'Crie, 3 vols. (Edinburgh, 1842).

—, Early Letters of Robert Wodrow, 1698-1709 (Edinburgh, 1937).

- The History of the Sufferings of the Church of Scotland, 2 vols. (Edinburgh, $1721-2)$.

The Yarmouth Tragedy: Shewing How by the Cruelty of Their Parents, Two Lovers Were Distroyed ([Edinburgh?], 1775).

Young, Edward, Edward Young: Night Thoughts, ed. Stephen Cornford (Cambridge, 1989)

Young Grigor's Ghost ([Edinburgh?], 1776). 


\section{Databases}

British Periodicals (ProQuest), http://bp.chadwyck.com.

Dictionary of the Scots Language (Scottish Language Dictionaries), http://www.dsl.ac.uk.

Early English Books Online (ProQuest), http://eebo.chadwyck.com/home.

Eighteenth Century Collections Online (Gale), http://galenet.galegroup.com/servlet/ECCO.

Eighteenth Century Journals (Adam Matthew), http://www.18thcjournals.amdigital.co.uk.

English Short Title Catalogue (British Library), http://estc.bl.uk.

Goodare, Julian et al., The Survey of Scottish Witchcraft (University of Edinburgh, 2003), http://www.shca.ed.ac.uk/witches.

Oxford Dictionary of National Biography (Oxford University Press), http://oxforddnb.com.

Oxford English Dictionary Online (Oxford University Press), http://www.oed.com.

Playbills of the Theatre Royal Edinburgh (National Library of Scotland), http://digital.nls.uk/playbills.

The Statistical Accounts of Scotland, 1791-1845 (University of Glasgow, University of Edinburgh), http://edina.ac.uk/stat-acc-scot.

The Word on the Street (National Library of Scotland, 2004), http://digital.nls.uk/broadsides.

All last accessed 1 Aug. 2015. 


\section{Theses}

Carruthers, Gerard Charles, 'The Invention of Scottish Literature during the Long Eighteenth Century' (University of Glasgow PhD thesis, 2001).

Cowdell, Paul, 'Belief in Ghosts in Post-War England' (University of Hertfordshire $\mathrm{PhD}$ thesis, 2011).

DeLucia, JoEllen M., “Tales of Other Times”: Scotland's Past and Women's Future in Eighteenth-Century British Writing' (Indiana University PhD thesis, 2007).

German, Kieran, 'Aberdeen, Aberdeenshire and Jacobitism in the North-East of Scotland, 1688-1750' (University of Aberdeen PhD thesis, 2010).

Henderson, Lizanne, 'Supernatural Traditions and Folk Beliefs in an Age of Transition: Witchcraft and Charming in Scotland, c.1670-1740' (University of Strathclyde $\mathrm{PhD}$ thesis, 2004).

Kornahrens, Wallace Douglas, 'Eucharistic Doctrine in Scottish Episcopacy, 16201875' (University of St. Andrews PhD thesis, 2008).

McKeever, Amanda Jane, 'The Ghost in Early Modern Protestant Culture: Shifting Perceptions of the Afterlife, 1450-1700' (University of Sussex DPhil thesis, 2010).

Newton, John Geoffrey, 'An Examination of Interpretations of Ghosts from the Reformation to the Close of the Seventeenth Century' (Durham University $\mathrm{PhD}$ thesis, 2003).

Raeburn, Gordon, 'The Long Reformation of the Dead in Scotland' (Durham University $\mathrm{PhD}$ thesis, 2012).

Ridder-Patrick, Jane, 'Astrology in Early Modern Scotland, ca.1560-1726' (University of Edinburgh $\mathrm{PhD}$ thesis, 2012). 
Shepherd, Christine M., 'Philosophy and Science in the Arts Curriculum of the Scottish Universities in the 17th Century' (University of Edinburgh $\mathrm{PhD}$ thesis, 1975).

\section{Published Secondary Sources}

Ahnert, Thomas, The Moral Culture of the Scottish Enlightenment, 1690-1805 (New Haven, 2014).

- 'The Soul, Moral Philosophy and Natural Religion in the Scottish Enlightenment', Eighteenth Century Thought, ii (2004), 233-53.

Alexander, William, Notes and Sketches Illustrative of Northern Rural Life in the Eighteenth Century (Edinburgh, 1877).

Allan, David, Scotland in the Eighteenth Century: Union and Enlightenment (Harlow, 2002).

- Virtue, Learning and the Scottish Enlightenment: Ideas of Scholarship in Early Modern History (Edinburgh, 1993).

Anderson, John, 'Sinclair, George (d. 1696?)', Oxford DNB (Oxford University Press, 2009), http://www.oxforddnb.com/view/article/25615, accessed 1 Aug. 2015.

Andriopoulos, Stefan, Ghostly Apparitions: German Idealism, the Gothic Novel, and Optical Media (Cambridge [Mass.], 2013).

Ariès, Philippe, The Hour of Our Death, trans. Helen Weaver (Oxford, 1981).

Atkinson, David, “'William and Margaret”: An Eighteenth-Century Ballad', Folk Music Journal, x (2014), 478.

Bailey, Richard, 'Scots and Scotticisms: Language and Ideology', Studies in Scottish 
Literature, xxvi (1991), 65-77.

Baker, Ian S., “"Do Ghosts Exist?”: A Summary of Parapsychological Research into Apparitional Experiences', in John Newton and Jo Bath (eds.), Early Modern Ghosts (Durham, 2002).

Baker, Timothy C., Contemporary Scottish Gothic: Mourning, Authenticity, and Tradition (Basingstoke, 2014).

Balaban, John, 'Blind Harry and “The Wallace”, Chaucer Review, viii (1974), 24151.

Bald, M. A., 'The Anglicisation of Scottish Printing', Scottish Historical Review, xxiii (1926), 107-15.

_- 'The Pioneers of Anglicised Speech in Scotland', Scottish Historical Review, xxiv (1927), 179-93.

Barber, Paul, Vampires, Burial, and Death: Folklore and Reality (New Haven, 1988).

Barker-Benfield, G. J., The Culture of Sensibility: Sex and Society in EighteenthCentury Britain (Chicago, 1992).

Barnett, S. J., The Enlightenment and Religion: The Myths of Modernity (Manchester, 2003).

Barry, Jonathan, 'Public Infidelity and Private Belief? The Discourse of Spirits in Enlightenment Bristol', in Owen Davies and Willem de Blécourt (eds.), Beyond the Witch Trials: Witchcraft and Magic in Enlightenment Europe (Manchester, 2004).

Bath, Jo, and John Newton, "'Sensible Proof of Spirits": Ghost Belief during the Later Seventeenth Century', Folklore, cxvii (2006), 1-14.

Beal, Joan, 'Syntax and Morphology', in Charles Jones (ed.), The Edinburgh History of the Scots Language (Edinburgh, 1997). 
Beik, William, ‘The Dilemma of Popular History', Past \& Present, cxli (1993), 20715.

Bell, Bill, 'The Scottish Book Trade at Home and Abroad, 1707-1918', in Ian Brown et al. (eds.), The Edinburgh History of Scottish Literature, Vol. 2: Enlightenment, Britain and Empire (1707-1918) (Edinburgh, 2007).

Bennett, Gillian, Alas, Poor Ghost!: Traditions of Belief in Story and Discourse (Logan [Utah], 1999).

(Jackson [Miss.], 2009).

— xcvii (1986), 3-14.

$\longrightarrow$, Traditions of Belief: Women and the Supernatural (London, 1987).

Bentinck, Charles Donald, Dornoch Cathedral and Parish (Inverness, 1926).

Benz, Ernst, Emanuel Swedenborg: Visionary Savant in the Age of Reason, trans. Nicholas Goodrick-Clarke (West Chester, 2002).

Berman, Morris, The Reenchantment of the World (Ithaca [N.Y.], 1981).

Bertie, David M., Scottish Episcopal Clergy, 1689-2000 (Edinburgh, 2000).

Beyer, Jürgen, 'On the Transformation of Apparition Stories in Scandinavia and Germany, c.1350-1700', Folklore, cx (1999), 39-47.

Black, G. F., County Folklore III: Examples of Printed Folklore Concerning the Orkney and Shetland Islands, ed. Northcote W. Thomas (London, 1903).

Bondeson, Jan, Buried Alive: The Terrifying History of Our Most Primal Fear (New York, 2002).

Bostridge, Ian, 'Witchcraft Repealed', in Jonathan Barry, Marianne Hester, and Gary 
Roberts (eds.), Witchcraft in Early Modern Europe: Studies in Culture and Belief (Cambridge, 1996).

Botting, Fred, Gothic: The New Critical Idiom, 2nd edn (Abingdon, 2014).

Bowie, Karin, Scottish Public Opinion and the Anglo-Scottish Union, 1699-1707 (Woodbridge, 2007).

Bowyer, R. A., 'The Role of the Ghost-Story in Mediaeval Christianity', in Helen Parish (ed.), Superstition and Magic in Early Modern Europe: A Reader (London, 2015).

Briggs, Katharine Mary, The Anatomy of Puck: An Examination of Fairy Beliefs Among Shakespeare's Contemporaries and Successors (London, 1959).

Briggs, Robin, Witches and Neighbours: The Social and Cultural Context of European Witchcraft, 2nd edn (Oxford, 2002).

Brown, Callum G., Religion and Society in Scotland since 1707 (Edinburgh, 1997).

Brown, Deborah, 'The Sixth Meditation: Descartes and the Embodied Self', in David Cunning (ed.), The Cambridge Companion to Descartes' Meditations (Cambridge, 2014).

Brown, Ian, Scottish Theatre: Diversity, Language, Continuity (Amsterdam; New York, 2013).

Brown, James, The History of Sanquhar (Dumfries, 1891).

Brown, Keith M., Noble Society in Scotland: Wealth, Family, and Culture from the Reformation to the Revolution (Edinburgh, 2000).

Brown, Rhona, 'Allan Ramsay, Robert Fergusson and Robert Burns', in David Sergeant and Fiona J. Stafford (eds.), Burns and Other Poets (Edinburgh, 2012).

, Robert Fergusson and the Scottish Periodical Press (Aldershot, 2012). 
Brown, Stewart J., 'Religion and Society to c.1900', in T. M Devine and Jenny Wormald (eds.), The Oxford Handbook of Modern Scottish History (Oxford, 2012).

Brown, Theo, 'The Black Dog', Folklore, lxix (1958), 175-92.

- The Fate of the Dead: A Study in Folk-Eschatology in the West Country After the Reformation (Cambridge, 1979).

Bruce, Steve, Scottish Gods: Religion in Modern Scotland, 1900-2012 (Oxford, 2014).

Buchan, David, 'Talerole Analysis and Child's Supernatural Ballads', in Joseph Harris (ed.), The Ballad and Oral Literature (Cambridge [Mass.], 1991).

Buchan, David, and Edward D. Ives, 'Tale Roles and Revenants: A Morphology of Ghosts', Western Folklore, xlv (1986), 143-60.

Burke, Peter, Popular Culture in Early Modern Europe, 3rd edn (Aldershot, 2009).

Burns, R. M., The Great Debate on Miracles: From Joseph Glanvill to David Hume (London, 1981).

Burns, William E., An Age of Wonders: Prodigies, Politics, and Providence in England, 1657-1727 (Manchester, 2002).

Buse, Peter, and Andrew Stott, 'Introduction: A Future for Haunting', in Peter Buse and Andrew Stott (eds.), Ghosts: Deconstruction, Psychoanalysis, History (Basingstoke, 1999).

Butler, Marilyn, 'Romanticism in England', in Roy Porter and Mikuláš Teich (eds.), Romanticism in National Context (Cambridge, 1988).

Bysveen, Josef, Epic Tradition and Innovation in James MacPherson's Fingal (Uppsala, 1982).

Caciola, Nancy, Discerning Spirits: Divine and Demonic Possession in the Middle 
Ages (Ithaca [N.Y.], 2003).

— , 'Wraiths, Revenants, and Ritual in Medieval Culture', Past \& Present, clii (1996), 3-45.

Cameron, Euan, Enchanted Europe: Superstition, Reason, and Religion, 1250-1750 (Oxford, 2010).

Campbell, John Gregorson, The Gaelic Otherworld: Superstitions of the Highlands and the Islands, ed. Ronald Black (Edinburgh, 2005).

Campbell, John Lorne, and Derick S. Thomson, Edward Lhuyd in the Scottish Highlands, 1699-1700 (Oxford, 1963).

Capp, B. S., Astrology and the Popular Press: English Almanacs 1500-1800 (London, 1979).

Carlson, Julie A., 'Baillie's Orra: Shrinking in Fear', in Thomas C. Crochunis (ed.), Joanna Baillie, Romantic Dramatist: Critical Essays (London, 2004).

Carpenter, Sarah, 'Early Scottish Drama', in R. D. S. Jack (ed.), The History of Scottish Literature, Vol. 1: Origins to 1600 (Aberdeen, 1988).

—, 'Scottish Drama until 1650', in Ian Brown (ed.), The Edinburgh Companion to Scottish Drama (Oxford, 2011).

Castle, Terry, The Female Thermometer: Eighteenth-Century Culture and the Invention of the Uncanny (Oxford, 1995).

Caw, James L., Scottish Painting Past and Present, 1620-1908 (Edinburgh, 1908).

Chadwick, N. K., 'Norse Ghosts (A Study in the Draugr and the Haugbúi)', Folklore, lvii (1946), 50-65.

Chapman, Malcolm, The Gaelic Vision in Scottish Culture (London, 1978).

Charlesworth, Michael, Landscape and Vision in Nineteenth-Century Britain and 
France (Aldershot, 2008).

Chesters, Timothy, Ghost Stories in Late Renaissance France: Walking by Night (Oxford, 2011).

Christian, William A., Apparitions in Late Medieval and Renaissance Spain (Princeton, 1981).

Clark, J. C. D., 'Providence, Predestination and Progress: Or, Did the Enlightenment Fail?', Albion, xxxv (2003), 559-89.

Clark, Stuart, Thinking with Demons: The Idea of Witchcraft in Early Modern Europe (Oxford, 1997).

- Vanities of the Eye: Vision in Early Modern European Culture (Oxford, 2007).

Clarke, Roger, A Natural History of Ghosts (London, 2012).

Clery, E. J., The Rise of Supernatural Fiction, 1762-1800 (Cambridge, 1995).

Clyde, Robert, From Rebel to Hero: The Image of the Highlander, 1745-1830 (East Linton, 1995).

Collins, Kenneth J., The Theology of John Wesley: Holy Love and the Shape of Grace (Nashville, 2007).

Copeland, Clare, and Jan Machielsen (eds.), Angels of Light? Sanctity and the Discernment of Spirits in the Early Modern Period (Leiden, 2013).

Cowan, Edward J. (ed.), The Ballad in Scottish History (East Linton, 2000).

- 'The Discovery of the Future: Prophecy and Second Sight in Scottish History', in Lizanne Henderson (ed.), Fantastical Imaginations: The Supernatural in Scottish History and Culture (Edinburgh, 2009).

—, 'Witch Persecution and Folk Belief in Lowland Scotland: The Devil's 
Decade', in Julian Goodare, Lauren Martin, and Joyce Miller (eds.), Witchcraft and Belief in Early Modern Scotland (Basingstoke, 2008).

Cowan, Edward J., and Mike Paterson (eds.), Folk in Print: Scotland's Chapbook Heritage, 1750-1850 (Edinburgh, 2007).

Craven, J. B., Church Life in South Ronaldshay and Burray in the Seventeenth Century (Kirkwall, 1911).

Crawford, Julie, Marvelous Protestantism: Monstrous Births in Post-Reformation England (Baltimore, 2005).

Crawford, Robert, Scotland's Books (London, 2007).

Crochunis, Thomas C. (ed.), Joanna Baillie, Romantic Dramatist: Critical Essays (London, 2004).

Cronin, Richard, Paper Pellets: British Literary Culture after Waterloo (Oxford, 2010).

Cunningham, Andrew, 'Medicine to Calm the Mind: Boerhaave's Medical System, and Why It Was Adopted in Edinburgh', in Andrew Cunningham and Roger French (eds.), The Medical Enlightenment of the Eighteenth Century (Cambridge, 1990).

Curry, Patrick, Prophecy and Power: Astrology in Early Modern England (Cambridge, 1989).

Darnton, Robert, Mesmerism and the End of the Enlightenment in France (Cambridge [Mass.], 1968).

Daston, Lorraine, 'Marvelous Facts and Miraculous Evidence in Early Modern Europe', Critical Inquiry, xviii (1991), 93-124.

Daston, Lorraine, and Katharine Park, Wonders and the Order of Nature, 1150-1750 (New York, 1998). 
Davidson, Hilda Roderick Ellis, and W. M. S. Russell (eds.), The Folklore of Ghosts (Cambridge, 1981).

Davidson, Jane P., Early Modern Supernatural: The Dark Side of European Culture, 1400-1700 (Santa Barbara, 2012).

Davies, Owen, The Haunted: A Social History of Ghosts (New York, 2007).

—, 'Introduction', in Owen Davies (ed.), Ghosts: A Social History, 5 vols. (London, 2010), i.

Davis, Colin, 'État Présent: Hauntology, Spectres and Phantoms', French Studies, lix (2005), 373-9.

Davis, Leith, Acts of Union: Scotland and the Literary Negotiation of the British Nation, 1707-1830 (Stanford, 1998).

Davis, Matthew M., “"Ask for the Old Paths”: Johnson and the Nonjurors', in J. C. D. Clark and Howard Erskine-Hill (eds.), The Politics of Samuel Johnson (Basingstoke, 2012).

Dawson, Jane E. A, Scotland Re-Formed, 1488-1587 (Edinburgh, 2007).

Dégh, Linda, Legend and Belief: Dialectics of a Folklore Genre (Bloomington, 2001).

Derrida, Jacques, Specters of Marx: The State of the Debt, the Work of Mourning, and the New International, trans. Peggy Kamuf (New York, 1994).

Devine, T. M., Clanship to Crofter's War: The Social Transformation of the Scottish Highlands (Manchester, 1994).

_ ' 'The Failure of Radical Reform in Scotland in the Late Eighteenth Century', in T. M. Devine (ed.), Conflict and Stability in Scottish Society, 1700-1850 (Edinburgh, 1990).

—, The Scottish Nation, 1700-2007 (London, 2006). 
Devine, T. M., and J. R Young (eds.), Eighteenth Century Scotland: New Perspectives (East Linton, 1999).

Doering-Manteuffel, Sabine, 'The Supernatural and the Development of Print Culture', in Owen Davies and Willem de Blécourt (eds.), Beyond the Witch Trials: Witchcraft and Magic in Enlightenment Europe (Manchester, 2004).

Donagan, Barbara, 'Providence, Chance and Explanation: Some Paradoxical Aspects of Puritan Views of Causation', Journal of Religious History, xi (1981), 385403.

Donaldson, Gordon, The Faith of the Scots (London, 1990).

Downes, Jeremy M., Recursive Desire: Rereading Epic Tradition (Tuscaloosa, 2014).

Drummond, Andrew Landale, and James Bulloch, The Scottish Church, 1688-1843: The Age of the Moderates (Edinburgh, 1973).

Duncan, Ian, 'Fanaticism and Enlightenment in Confessions of a Justified Sinner', in Sharon Alker and Holly Faith Nelson (eds.), James Hogg and the Literary Marketplace: Scottish Romanticism and the Working-Class Author (Farnham, 2009).

—_, Scott's Shadow: The Novel in Romantic Edinburgh (Princeton, 2007).

—, 'Walter Scott, James Hogg and Scottish Gothic', in David Punter (ed.), A New Companion to the Gothic (Oxford, 2012).

Duncan, Ian, Leith Davis, and Janet Sorensen, 'Introduction', in Leith Davis, Ian Duncan, and Janet Sorensen (eds.), Scotland and the Borders of Romanticism (Cambridge, 2004).

Dymond, Anne, 'Displaying the Arlésienne: Museums, Folklife and Regional Identities in France', in Timothy Baycroft and David Hopkin (eds.), Folklore and Nationalism in Europe During the Long Nineteenth Century (Leiden, 
2012).

Edgar, Andrew, Old Church Life in Scotland: Lectures on Kirk-Session and Presbytery Records (Paisley, 1886).

Edwards, Kathryn A. (ed.), Werewolves, Witches, and Wandering Spirits: Traditional Belief and Folklore in Early Modern Europe (Kirksville, 2002).

Ellis, Markman, The Politics of Sensibility: Race, Gender and Commerce in the Sentimental Novel (Cambridge, 1996).

Emerson, Roger, 'Did the Scottish Enlightenment Emerge in an English Cultural Province?', Lumen: Selected Proceedings from the Canadian Society for Eighteenth-Century Studies, xiv (1995), 1-24.

_ ' 'The Religious, the Secular and the Worldly: Scotland 1680-1800', in James E. Crimmins (ed.), Religion, Secularization and Political Thought: Thomas Hobbes to J. S. Mill (London, 1989).

Faubert, Michelle, 'John Ferriar's Psychology, James Hogg's Justified Sinner, and the Gay Science of Horror Writing', in Thomas H. Schmid and Michelle Faubert (eds.), Romanticism and Pleasure (Basingstoke, 2010).

Ferber, Michael, 'Introduction', in Michael Ferber (ed.), A Companion to European Romanticism (Oxford, 2005).

Fielding, Penny, 'The Private Memoirs and Confessions of a Justified Sinner: Approaches', in Ian Duncan and Douglas S. Mack (eds.), The Edinburgh Companion to James Hogg (Edinburgh, 2012).

Findlay, Bill, 'Beginnings to 1700', in Bill Findlay (ed.), A History of Scottish Theatre (Edinburgh, 1998).

Finlay, Richard J., 'Caledonia or North Britain? Scottish Identity in the Eighteenth Century', in Dauvit Broun, Richard J. Finlay, and Michael Lynch (eds.), Image and Identity: The Making and Re-Making of Scotland through the 
Ages (Edinburgh, 1998).

Finucane, R. C., Ghosts: Appearances of the Dead and Cultural Transformation (Amherst [N.Y.], 1996).

Fisher, Keely, 'The Crying of Ane Play: Robin Hood and Maying in SixteenthCentury Scotland', in John Pitcher (ed.), Medieval and Renaissance Drama in England, Vol. 12 (Cranbury, 1999).

Fleming, Maurice, The Ghost O'Mause: And Other Tales and Traditions of East Perthshire (Edinburgh, 1995).

Ford, Jennifer, Coleridge on Dreaming: Romanticism, Dreams and the Medical Imagination (Cambridge, 1997).

Fox, Adam, 'Approaches to Ephemera: Scottish Broadsides, 1679-1746', in Kevin Murphy and Sally O'Driscoll (eds.), Studies in Ephemera: Text and Image in Eighteenth-Century Print (Lanham, 2013).

_ ' The Emergence of the Scottish Broadside Ballad in the Late Seventeenth and Early Eighteenth Centuries', Journal of Scottish Historical Studies, xxxi (2011), 169-94.

__ "Little Story Books" and "Small Pamphlets" in Edinburgh, 1680-1760: The Making of the Scottish Chapbook', Scottish Historical Review, xcii (2013), 207-30.

—, Oral and Literate Culture in England, 1500-1700 (Oxford, 2000).

Foyster, Elizabeth A., and Christopher A. Whatley (eds.), A History of Everyday Life in Scotland, 1600 to 1800 (Edinburgh, 2010).

Frace, Ryan K., 'Religious Toleration in the Wake of Revolution: Scotland on the Eve of Enlightenment (1688-1710s)', History, xciii (2008), 355-75.

Fraser, William, The Earls of Cromartie, Their Kindred, Country and 
Correspondence, 2 vols. (Edinburgh, 1876).

Gamer, Michael, 'Gothic Fictions and Romantic Writing in Britain', in Jerrold E. Hogle (ed.), The Cambridge Companion to Gothic Fiction (Cambridge, 2002).

- Romanticism and the Gothic: Genre, Reception, and Canon Formation (Cambridge, 2000).

Garside, Peter, 'Publishing 1800-30', in Bill Bell (ed.), The Edinburgh History of the Book in Scotland, Vol. 3: Ambition and Industry 1800-1880 (Edinburgh, 2007).

Gaskill, Malcolm, Crime and Mentalities in Early Modern England (Cambridge, 2000).

_ , 'The Displacement of Providence: Policing and Prosecution in Seventeenthand Eighteenth-Century England', Continuity and Change, xi (1996), 34174 .

Gatrell, V. A. C., The Hanging Tree: Execution and the English People 1770-1868 (Oxford, 1996).

Gaukroger, Stephen, Descartes: An Intellectual Biography (Oxford, 1997).

Gay, Peter, The Enlightenment: An Interpretation (New York, 1966).

Geary, Robert F., The Supernatural in Gothic Fiction: Horror, Belief, and Literary Change (Lewiston [N.Y.], 1992).

Gellera, Giovanni, 'The Philosophy of Robert Forbes: A Scottish Scholastic Response to Cartesianism', Journal of Scottish Philosophy, xi (2013), 191211.

Gent, Jacqueline Van, Magic, Body and the Self in Eighteenth-Century Sweden (Leiden, 2009). 
Gifford, Douglas, "Nathaniel Gow's Toddy": The Supernatural in Lowland Scottish Literature from Burns and Scott to the Present Day', in Lizanne Henderson (ed.), Fantastical Imaginations: The Supernatural in Scottish History and Culture (Edinburgh, 2009).

Glouberman, M., Descartes: The Probable and the Certain (Amsterdam, 1986).

Le Goff, Jacques, The Birth of Purgatory, trans. Arthur Goldhammer (Chicago, 1986).

Goodare, Julian, 'The Cult of the Seely Wights in Scotland', Folklore, cxxiii (2012), $198-219$.

—, 'Scotland', in Bob Scribner, Roy Porter, and Mikuláš Teich (eds.), The Reformation in National Context (Cambridge, 1994).

— , 'Scottish Witchcraft in Its European Context', in Julian Goodare, Lauren Martin, and Joyce Miller (eds.), Witchcraft and Belief in Early Modern Scotland (Basingstoke, 2008).

- 'The Scottish Witchcraft Panic of 1597', in Julian Goodare (ed.), The Scottish Witch-Hunt in Context (Manchester, 2002).

- (ed.), The Scottish Witch-Hunt in Context (Manchester, 2002).

—, 'Witchcraft in Scotland', in Brian P. Levack (ed.), The Oxford Handbook of Witchcraft in Early Modern Europe and Colonial America (Oxford, 2013).

_- 'Women and the Witch-Hunt in Scotland', Social History, xxiii (1998), 288308.

Goodare, Julian et al., 'Introduction to Scottish Witchcraft', The Survey of Scottish Witchcraft (University of Edinburgh, 2003), http://www.shca.ed.ac.uk/Research/witches/introduction.html, accessed 1 Aug. 2015. 
Goodare, Julian, Lauren Martin, and Joyce Miller (eds.), Witchcraft and Belief in Early Modern Scotland (Basingstoke, 2008).

Gordon, Anne, Candie for the Foundling (Edinburgh, 1992).

Gordon, Avery, Ghostly Matters: Haunting and the Sociological Imagination, 2nd edn (Minneapolis, 2008).

Gordon, Bruce, 'Malevolent Ghosts and Ministering Angels: Apparitions and Pastoral Care in the Swiss Reformation', in Bruce Gordon and Peter Marshall (eds.), The Place of the Dead: Death and Remembrance in Late Medieval and Early Modern Europe (Cambridge, 2000).

Gordon, J. F. S., 'Introit', in William Ogilvie, The Laird O' Coul's Ghost (London, 1892).

Göttler, Christine, and Wolfgang Neuber (eds.), Spirits Unseen: The Representation of Subtle Bodies in Early Modern European Culture (Leiden, 2008).

Gottlieb, Evan, Feeling British: Sympathy and National Identity in Scottish and English Writing, 1707-1832 (Lewisburg [Pa.], 2007).

Gowing, Laura, 'The Haunting of Susan Lay: Servants and Mistresses in Seventeenth-Century England', Gender \& History, xiv (2002), 183-201.

Graham, Gordon, The Re-Enchantment of the World: Art versus Religion (Oxford, 2007).

Graham, Michael F., The Blasphemies of Thomas Aikenhead: Boundaries of Belief on the Eve of the Enlightenment (Edinburgh, 2008).

Greenblatt, Stephen, Hamlet in Purgatory (Princeton, 2001).

Gribben, Crawford, 'Religion and Scottish Romanticism', in Murray Pittock (ed.), The Edinburgh Companion to Scottish Romanticism (Edinburgh, 2011).

Hall, Daniel, French and German Gothic Fiction in the Late Eighteenth Century 
(Bern, 2005).

Handley, Sasha, 'Apparitions and Anglicanism in 1750s Warwickshire', in Peter Clarke and Tony Claydon (eds.), The Church, the Afterlife and the Fate of the Soul (Woodbridge, 2009).

— , 'Reclaiming Ghosts in 1690s England', in Kate Cooper and Jeremy Gregory (eds.), Signs, Wonders, Miracles: Representations of Divine Power in the Life of the Church (Woodbridge, 2005).

- Visions of an Unseen World: Ghost Beliefs and Ghost Stories in EighteenthCentury England (London, 2007).

Hanegraaff, Wouter J., 'How Magic Survived the Disenchantment of the World', Religion, xxxiii (2003), 357-80.

Hattaway, Michael, Elizabethan Popular Theatre: Plays in Performance (London, 1982).

Hefling, Charles, 'Scotland: Episcopalians and Nonjurors', in Charles Hefling and Cynthia Shattuck (eds.), The Oxford Guide to The Book of Common Prayer: A Worldwide Survey (Oxford, 2006).

Heiland, Donna, Gothic and Gender: An Introduction (Oxford, 2004).

Henderson, Hamish, 'The Ballad and Popular Tradition to 1660', in R. D. S. Jack (ed.), The History of Scottish Literature, Vol. 1: Origins to 1600 (Aberdeen, 1988).

Henderson, Lizanne, 'The Road to Elfland: Fairy Belief and the Child Ballads', in Edward J. Cowan (ed.), The Ballad in Scottish History (East Linton, 2000).

—, 'The Survival of Witchcraft Prosecutions and Witch Belief in South-West Scotland', Scottish Historical Review, 1xxxv (2006), 52-74.

Henderson, Lizanne, and Edward J. Cowan, Scottish Fairy Belief: A History (East 
Linton, 2001).

Heyd, Michael, Be Sober and Reasonable: The Critique of Enthusiasm in the Seventeenth and Early Eighteenth Centuries (Leiden, 1995).

Hoffman, Paul, Essays on Descartes (New York, 2009).

Houran, James, and Rense Lange (eds.), Hauntings and Poltergeists: Multidisciplinary Perspectives (Jefferson [N.C.], 2001).

Houston, R. A., Madness and Society in Eighteenth-Century Scotland (Oxford, 2000).

- Punishing the Dead?: Suicide, Lordship, and Community in Britain, 15001830 (Oxford, 2010).

—, Scottish Literacy and the Scottish Identity: Illiteracy and Society in Scotland and Northern England, 1600-1800 (Cambridge, 2002).

- Social Change in the Age of Enlightenment: Edinburgh, 1660-1760 (Oxford, 1994).

—, 'Women in the Economy and Society of Scotland, 1500-1800', in R. A. Houston and I. D. Whyte (eds.), Scottish Society, 1500-1800 (Cambridge, 1989).

Houston, R. A., and I. D. Whyte, 'Introduction: Scottish Society in Perspective', in R. A. Houston and I. D. Whyte (eds.), Scottish Society, 1500-1800 (Cambridge, 1989).

Hunter, Michael, 'Introduction', in Michael Hunter (ed.), The Occult Laboratory: Magic, Science, and Second Sight in Late Seventeenth-Century Scotland (Woodbridge, 2001).

— , 'The Problem of "Atheism" in Early Modern England', Transactions of the Royal Historical Society, xxxv (1985), 135-57. 
—, Robert Boyle, 1627-91: Scrupulosity and Science (Woodbridge, 2000).

Hunter, Michael and David Wootton, 'Introduction', in Michael Hunter and David Wootton (eds.), Atheism from the Reformation to the Enlightenment (Oxford, 1992).

Hutton, Ronald, The Stations of the Sun: A History of the Ritual Year in Britain (Oxford, 1996).

Israel, Jonathan I., Democratic Enlightenment: Philosophy, Revolution, and Human Rights 1750-1790 (Oxford, 2011).

—, Radical Enlightenment: Philosophy and the Making of Modernity, 16501750 (Oxford, 2001).

Jakobsson, Ármann, 'The Fearless Vampire Killers: A Note about the Icelandic Draugr and Demonic Contamination in Grettis Saga', Folklore, cxx (2009), 307-16.

Jestice, Phyllis G., Encyclopedia of Irish Spirituality (Santa Barbara, 2000).

Jones, Charles, 'Nationality and Standardisation in Eighteenth-Century Scotland', in Raymond Hickey (ed.), Eighteenth-Century English: Ideology and Change (Cambridge, 2010).

Jones, Leonidas M., 'The Scott-Christie Duel', Texas Studies in Literature and Language, xii (1971), 605-29.

Joynes, Andrew (ed.), Medieval Ghost Stories: An Anthology of Miracles, Marvels, and Prodigies (Woodbridge, 2001).

Kaplan, Barbara Beigun, 'Turberville, Daubeney (1612-1696)', Oxford DNB (Oxford University Press, 2004), http://www.oxforddnb.com/view/article/27823, accessed 1 Aug. 2015.

Kennedy, David J., Eucharistic Sacramentality in an Ecumenical Context (Farnham, 
2013).

Keyworth, G. David, 'Was the Vampire of the Eighteenth Century a Unique Type of Undead-Corpse?', Folklore, cxvii (2006), 241-60.

Kidd, Colin, 'Conditional Britons: The Scots Covenanting Tradition and the Eighteenth-Century British State', English Historical Review, cxvii (2002), $1147-76$.

-, 'Gaelic Antiquity and National Identity in Enlightenment Ireland and Scotland', English Historical Review, cix (1994), 1197-1214.

— , 'The Scottish Enlightenment and the Supernatural', in Lizanne Henderson (ed.), Fantastical Imaginations: The Supernatural in Scottish History and Culture (Edinburgh, 2009).

— Subverting Scotland's Past: Scottish Whig Historians and the Creation of an Anglo-British Identity, 1689-1830 (Cambridge, 1993).

Killick, Tim, British Short Fiction in the Early Nineteenth Century: The Rise of the Tale (Aldershot, 2008).

Kim, Yosep, The Identity and the Life of the Church: John Calvin's Ecclesiology in the Perspective of His Anthropology (Eugene, 2014).

King, Charles W., 'The Roman Manes: The Dead as Gods', in Mu-chou Poo (ed.), Rethinking Ghosts in World Religions (Leiden, 2009).

Knowles, Claire, Sensibility and Female Poetic Tradition, 1780-1860: The Legacy of Charlotte Smith (Farnham, 2009).

Köhler-Zülch, Ines, 'Heinrich Prohle: A Successor to the Brothers Grimm', in Donald Haase (ed.), The Reception of Grimms' Fairy Tales: Responses, Reactions, Revisions (Detroit, 1993).

Kornahrens, Douglas, 'Praying for the Christian Departed: A Brief View of the 
Doctrine and Practice in Scottish Episcopacy', Theology in Scotland, xviii (2011), 47-79.

Kyle, Richard, 'John Knox's Concept of Divine Providence and Its Influence on His Thought', Albion, xviii (1986), 395-410.

Landy, Joshua, and Michael Saler (eds.), The Re-Enchantment of the World: Secular Magic in a Rational Age (Stanford, 2009).

Lang, Andrew, Cock Lane and Common-Sense (London, 1894).

Larner, Christina, Enemies of God: The Witch-Hunt in Scotland (London, 1981).

Lecouteux, Claude, Return of the Dead: Ghosts, Ancestors, and the Transparent Veil of the Pagan Mind, trans. John E. Graham (Rochester [Vt.], 2009).

Lenman, Bruce, The Jacobite Risings in Britain, 1689-1746 (Dalkeith, 1980).

Levack, Brian P., Witch-Hunting in Scotland: Law, Politics and Religion (London, 2008).

Lewis, Belinda, 'Protestantism, Pragmatism and Popular Religion: A Case Study of Early Modern Ghosts', in John Newton and Jo Bath (eds.), Early Modern Ghosts (Durham, 2002).

Llewellyn, Nigel, Art of Death: Visual Culture in the English Death Ritual c.1500c.1800 (London, 1991).

Lovat-Fraser, J. A., John Stuart, Earl of Bute (Cambridge, 1912).

Love, Dane, Scottish Ghosts (London, 1995).

Lyle, Emily (ed.), Scottish Ballads (Edinburgh, 1994).

Lynch, Michael, 'Preaching to the Converted? Perspectives on the Scottish Reformation', in A. A. MacDonald, M. Lynch, and I. B. Cowan (eds.), The Renaissance in Scotland: Studies in Literature, Religion, History and Culture 
(Leiden, 1994).

- Scotland: A New History (London, 1992).

MacDonald, Alexander, 'Highland Ghosts', Transactions of the Gaelic Society of Inverness, xiv (1899), 40-9.

Macdougall, Norman, James IV: The Stewart Dynasty in Scotland (Edinburgh, 2006).

Macfarlane, Alan, Witchcraft in Tudor and Stuart England: A Regional and Comparative Study (London, 1970).

Macinnes, Allan I., Union and Empire: The Making of the United Kingdom in 1707 (Cambridge, 2007).

Mackelvie, William, Annals and Statistics of the United Presbyterian Church (Edinburgh, 1873).

Mackie, R. L., King James IV of Scotland: A Brief Survey of His Life and Times (London, 1976).

MacKinnon, Donald and Alick Morrison, The MacLeods: The Genealogy of a Clan, 5 vols. (Edinburgh, 1968-76).

Maclagan, R. C., 'Ghost Lights of the West Highlands', Folklore, viii (1897), 20356.

MacQueen, John, 'Introduction', in John MacQueen (ed.), The Phanaticks (Woodbridge, 2012).

MacQueen, John, and Winifred MacQueen, 'Introduction', in John MacQueen and Winifred MacQueen (eds.), The Latin Poems (Assen, 2009).

— , 'Texts, Translations and Commentaries', in John MacQueen and Winifred MacQueen (eds.), The Latin Poems (Assen, 2009).

Maggi, Armando, In the Company of Demons: Unnatural Beings, Love, and Identity 
in the Italian Renaissance (Chicago, 2006).

Maple, Eric, The Realm of Ghosts (London, 1964).

Marshall, Peter, Beliefs and the Dead in Reformation England (Oxford, 2002).

—, 'Deceptive Appearances: Ghosts and Reformers in Elizabethan and Jacobean England', in Helen Parish and William G. Naphy (eds.), Religion and Superstition in Reformation Europe (Manchester, 2002).

—, 'The Guardian Angel in Protestant England', in Joad Raymond (ed.), Conversations with Angels: Essays Towards a History of Spiritual Communication, 1100-1700 (Basingstoke, 2011).

_ _ "The Map of God's Word": Geographies of the Afterlife in Tudor and Early Stuart England', in Bruce Gordon and Peter Marshall (eds.), The Place of the Dead: Death and Remembrance in Late Medieval and Early Modern Europe (Cambridge, 2000).

_- Mother Leakey and the Bishop: A Ghost Story (Oxford, 2007).

Marshall, Peter and Alexandra Walsham (eds.), Angels in the Early Modern World (Cambridge, 2006).

Mason, Roger (ed.), John Knox and the British Reformations (Aldershot, 1998).

Mathison, Hamish, 'Gothic Poetry in Scotland: The Ghaistly Eighteenth Century', Gothic Studies, xiv (2012), 34-46.

Maxwell-Stuart, P. G., Ghosts: A History of Phantoms, Ghouls \& Other Spirits of the Dead (Stroud, 2006).

— Poltergeists: A History of Violent Ghostly Phenomena (Stroud, 2011).

—, 'Witchcraft and Magic in Eighteenth-Century Scotland', in Owen Davies and Willem de Blécourt (eds.), Beyond the Witch Trials: Witchcraft and Magic in Enlightenment Europe (Manchester, 2004). 
McCallum, John, Reforming the Scottish Parish: The Reformation in Fife, 15601640 (Aldershot, 2010).

McCorristine, Shane, Spectres of the Self: Thinking About Ghosts and Ghost-Seeing in England, 1750-1920 (Cambridge, 2010).

McDannell, Colleen, and Bernhard Lang, Heaven: A History, 2nd edn (New Haven, 2001).

McIntosh, John R., Church and Theology in Enlightenment Scotland: The Popular Party, 1740-1800 (East Linton, 1997).

McKerlie, P. H., History of the Lands and Their Owners in Galloway, 5 vols. (Edinburgh, 1870-9).

McLean, Scott A., 'Cleansing the Hawker's Basket: Popular Literature and the Cheap Periodical Press in Scotland', Studies in Scottish Literature, xxxii (2001), 88100.

McManners, John, Death and the Enlightenment: Changing Attitudes to Death Among Christians and Unbelievers in Eighteenth-Century France (Oxford, 1981).

McNeil, Kenneth, Scotland, Britain, Empire: Writing the Highlands, 1760-1860 (Columbus, 2007).

Means, J. A., 'The Composition of The Grave', Studies in Scottish Literature, $\mathrm{x}$ (1972), 3-9.

Meek, Donald E., 'The Gaelic Ballads of Scotland: Creativity and Adaptation', in Howard Gaskill (ed.), Ossian Revisited (Edinburgh, 1991).

Menn, Stephen, Descartes and Augustine (Cambridge, 2002).

Midelfort, H. C. Erik, Exorcism and Enlightenment: Johann Joseph Gassner and the Demons of Eighteenth-Century Germany (New Haven, 2005). 
—_, 'Madness and Civilization in Early Modern Europe: A Reappraisal of Michel Foucault', in Barbara C. Malament (ed.), After the Reformation: Essays in Honor of J.H. Hexter (Manchester, 1980).

Miles, Robert, Gothic Writing, 1750-1820: A Genealogy, 2nd edn (Manchester, 2002).

Miller, Frank, 'The Laird of Coul's Ghost: A Galloway Chap-Book', Transactions of the Dumfriesshire and Galloway Natural History \& Antiquarian Society, 3rd ser., xiv (1927), 259-72.

Miller, Joyce, 'Men in Black: Appearances of the Devil in Early Modern Scottish Witchcraft Discourse', in Julian Goodare, Lauren Martin, and Joyce Miller (eds.), Witchcraft and Belief in Early Modern Scotland (Basingstoke, 2008).

Monod, Paul Kléber, Solomon's Secret Arts: The Occult in the Age of Enlightenment (New Haven, 2013).

Montgomerie, Alexander, and Patrick Hume, 'The Flyting Betwixt Montgomery and Polwart', in James Cranstoun (ed.), The Poems of Alexander Montgomerie (Edinburgh, 1887).

Morris, David B., 'A Poetry of Absence', in John Sitter (ed.), The Cambridge Companion to Eighteenth-Century Poetry (Cambridge, 2001).

Morrison, Robert, and Daniel S. Roberts, "'A Character so Various, and yet so Indisputably Its Own": A Passage to Blackwood's Edinburgh Magazine', in Robert Morrison and Daniel S. Roberts, (eds.), Romanticism and Blackwood's Magazine: 'An Unprecedented Phenomenon' (Basingstoke, 2013).

Morton, Graeme, Unionist-Nationalism: Governing Urban Scotland, 1830-1860 (East Linton, 1999).

Mullan, David George, Narratives of the Religious Self in Early-Modern Scotland 
(Aldershot, 2010).

Murphy, Andrew, 'Shakespeare Goes to Scotland: A Brief History of Scottish Editions', in Willy Maley and Andrew Murphy (eds.), Shakespeare and Scotland (Manchester, 2004).

Murray, Alexander, Suicide in the Middle Ages, Vol. 2: The Curse on Self-Murder (Oxford, 2000).

Nash, David, and Anne-Marie Kilday, Cultures of Shame: Exploring Crime and Morality in Britain 1600-1900 (Basingstoke, 2010).

Nenadic, Stana, 'The Rise of the Urban Middle Classes', in Tom M. Devine and Rosalind Mitchison (eds.), People and Society in Scotland, Vol. 1: 1760-1830 (Edinburgh, 1998).

Newton, Michael, A Handbook of the Scottish Gaelic World (Dublin, 2000).

Oppenheim, Janet, The Other World: Spiritualism and Psychical Research in England, 1850-1914 (Cambridge, 1988).

Parisot, Eric, Graveyard Poetry: Religion, Aesthetics and the Mid-EighteenthCentury Poetic Condition (Farnham, 2013).

Parker, Geoffrey, 'Success and Failure during the First Century of the Reformation', Past \& Present, cxxxvi (1992), 43-82.

Parker, Holt N., 'Toward a Definition of Popular Culture', History \& Theory, 1 (2011), 147-70.

Parker, Mark, Literary Magazines and British Romanticism (Cambridge, 2001).

Parkinson, David J., "The Legend of the Bischop of St. Androis Lyfe" and the Survival of Scottish Poetry', Early Modern Literary Studies, ix (2003), 5.124. 
Parsons, Coleman O., 'Introduction', in George Sinclair, Satan's Invisible World Discovered (Gainesville, 1969).

Partridge, Christopher, The Re-Enchantment of the West: Alternative Spiritualities, Sacralization, Popular Culture and Occulture, 2 vols. (London, 2004-5).

Pearl, Jonathan L., 'Sabbat', in Richard M. Golden (ed.), Encyclopedia of Witchcraft: The Western Tradition, 4 vols. (Santa Barbara, 2006), iv.

Pearson, Jacqueline, “"Then she asked it, what were its Sisters names?": Reading between the Lines in Seventeenth-Century Pamphlets of the Supernatural', Seventeenth Century, xxviii (2013), 63-78.

Perkins, Maureen, 'The Meaning of Dream Books', in Daniel Pick and Lyndal Roper (eds.), Dreams and History: The Interpretation of Dreams from Ancient Greece to Modern Psychoanalysis (Hove, 2004).

Pittock, Murray, 'Enlightenment, Romanticism and the Scottish Canon', in Gerard Carruthers and Liam McIlvanney (eds.), The Cambridge Companion to Scottish Literature (Cambridge, 2012).

— , 'Introduction: What Is Scottish Romanticism?', in Murray Pittock (ed.), The Edinburgh Companion to Scottish Romanticism (Edinburgh, 2011).

- The Invention of Scotland: The Stuart Myth and the Scottish Identity, 1638 to the Present (London, 1991).

—, Scottish and Irish Romanticism (Oxford, 2008).

Plank, Geoffrey, Rebellion and Savagery: The Jacobite Rising of 1745 and the British Empire (Philadelphia, 2005).

Pócs, Éva, Between the Living and the Dead: A Perspective on Witches and Seers in the Early Modern Age (Budapest, 1999).

Porter, Roy, 'Death and the Doctors in Georgian England', in Ralph Houlbrooke 
(ed.), Death, Ritual, and Bereavement (London, 1989).

- Enlightenment: Britain and the Creation of the Modern World (London, 2000).

Puhle, Annekatrin, 'Ghosts, Apparitions and Poltergeist Incidents in Germany between 1700 and 1900', Journal of the Society for Psychical Research, 1xiii (1999), 292-305.

Punter, David, 'Scottish and Irish Gothic', in Jerrold E. Hogle (ed.), The Cambridge Companion to Gothic Fiction (Cambridge, 2002).

Purkiss, Diane, Troublesome Things: A History of Fairies and Fairy Stories (London, 2000).

Rackwitz, Martin, Travels to Terra Incognita: The Scottish Highlands and Hebrides in Early Modern Travellers' Accounts, c.1600 to 1800 (Münster, 2007).

Raffe, Alasdair, The Culture of Controversy: Religious Arguments in Scotland, 16601714 (Woodbridge, 2012).

—, 'Intellectual Change before the Enlightenment: Scotland, the Netherlands and the Reception of Cartesian Thought, 1650-1700', Scottish Historical Review, xciv (2015), 24-47.

— of 1688-1690', Historical Journal, liii (2010), 317-37.

— in Scotland, 1660-1715', English Historical Review, cxxv (2010), 570-98.

Ramsay, John, Scotland and Scotsmen in the Eighteenth Century, ed. Alexander Allardyce, 2 vols. (Edinburgh, 1888).

Redwood, John, Reason, Ridicule, and Religion: The Age of Enlightenment in England, 1660-1750 (Cambridge [Mass.], 1976). 
Richardson, Ruth, Death, Dissection and the Destitute (London, 1987).

Risse, Guenter B., New Medical Challenges During the Scottish Enlightenment (Amsterdam, 2005).

Robertson, Fiona, Legitimate Histories: Scott, Gothic, and the Authorities of Fiction (Oxford, 1994).

Robinson, Christine, and Roibeard Ó Maolalaigh, 'The Several Tongues of a Single Kingdom: The Languages of Scotland 1314-1707', in Ian Brown et al. (eds.), The Edinburgh History of Scottish Literature, Vol. 1: From Columba to the Union (until 1707) (Edinburgh, 2007).

Roper, Lyndal, 'Witchcraft and Fantasy in Early Modern Germany', History Workshop, xxxii (1991), 19-43.

Roxburgh, Kenneth B. E., Thomas Gillespie and the Origins of the Relief Church in 18th Century Scotland (Bern, 1999).

Royan, Nicola and Dauvit Broun, 'Versions of Scottish Nationhood, c.850-1707', in Ian Brown et al. (eds.), The Edinburgh History of Scottish Literature, Vol. 1: From Columba to the Union (until 1707) (Edinburgh, 2007).

Rugg, Julie, 'From Reason to Regulation: 1760-1850', in Peter C. Jupp and Clare Gittings (eds.), Death in England: An Illustrated History (Manchester, 1999).

Sambrook, James, James Thomson, 1700-1748: A Life (Oxford, 1991).

Schmitt, Jean-Claude, Ghosts in the Middle Ages: The Living and the Dead in Medieval Society, trans. Teresa Lavender Fagan (Chicago, 1998).

Schofield, William Henry, Mythical Bards and The Life of William Wallace (Cambridge [Mass.], 1920).

Scott, Hew, Fasti Ecclesice Scoticance, new edn, 7 vols. (Edinburgh, 1915-28).

Scott, W. W., 'Lindsay, Robert, of Pitscottie (c.1532-c.1586)', Oxford DNB (Oxford 
University Press, 2004), http://www.oxforddnb.com/view/article/16715, accessed 1 Aug. 2015.

Scribner, Bob, 'Is a History of Popular Culture Possible?', History of European Ideas, x (1989), 175-91.

_- 'The Reformation, Popular Magic, and the "Disenchantment of the World", Journal of Interdisciplinary History, xxiii (1993), 475-94.

Scullion, Adrienne, 'The Eighteenth Century', in Bill Findlay (ed.), A History of Scottish Theatre (Edinburgh, 1998).

Sharpe, James, 'Witch-Hunting and Witch Historiography: Some Anglo-Scottish Comparisons', in Julian Goodare (ed.), The Scottish Witch-Hunt in Context (Manchester, 2002).

Sharp, L. W., 'Introduction', in L. W. Sharp (ed.), Early Letters of Robert Wodrow (Edinburgh, 1937).

Shaw, Jane, Miracles in Enlightenment England (New Haven, 2006).

Sher, Richard B., Church and University in the Scottish Enlightenment: The Moderate Literati of Edinburgh (Edinburgh, 1985).

- The Enlightenment and the Book: Scottish Authors and Their Publishers in Eighteenth-Century Britain, Ireland, and America (Chicago, 2007).

Shields, Juliet, Sentimental Literature and Anglo-Scottish Identity, 1745-1820 (Cambridge, 2010).

Simpson, Jacqueline, Icelandic Folktales and Legends (Berkeley [Calif.], 1972).

— England', Folklore, cxiv (2003), 389-402.

—, “The Weird Sisters Wandering": Burlesque Witchery in Montgomerie's Flyting', Folklore, cvi (1995), 9-20. 
Simpson, Kenneth, The Protean Scot: The Crisis of Identity in Eighteenth Century Scottish Literature (Aberdeen, 1988).

Simpson, Robert, History of Sanquhar (Edinburgh, 1853).

Skoczylas, Anne, Mr Simson's Knotty Case: Divinity, Politics, and Due Process in Early Eighteenth-Century Scotland (Montreal, 2001).

Smith, Andrew, Gothic Literature (Edinburgh, 2007).

Smith, Nigel, 'The Charge of Atheism and the Language of Radical Speculation, 1640-1660', in Michael Hunter and David Wootton (eds.), Atheism from the Reformation to the Enlightenment (Oxford, 1992).

Soergel, Philip M., Miracles and the Protestant Imagination: The Evangelical Wonder Book in Reformation Germany (New York, 2012).

Spicer, Andrew, "Defyle Not Christ's Kirk with Your Carrion": Burial and the Development of Burial Aisles in Post-Reformation Scotland', in Bruce Gordon and Peter Marshall (eds.), The Place of the Dead: Death and Remembrance in Late Medieval and Early Modern Europe (Cambridge, 2000).

Spinks, Bryan D., Liturgy in the Age of Reason: Worship and Sacraments in England and Scotland 1662-c.1800 (Farnham, 2008).

Springborg, Patricia, 'Hobbes on Religion', in Tom Sorell (ed.), The Cambridge Companion to Hobbes (Cambridge, 1996).

Sprinker, Michael (ed.), Ghostly Demarcations: A Symposium on Jacques Derrida's Spectres of Marx (London, 1999).

Stafford, Fiona J., "Dangerous Success": Ossian, Wordsworth, and English Romantic Literature', in Howard Gaskill (ed.), Ossian Revisited (Edinburgh, 1991). 
—, 'Scottish Romanticism and Scotland in Romanticism', in Michael Ferber (ed.), A Companion to European Romanticism (Oxford, 2005).

- The Sublime Savage: James McPherson and the Poems of Ossian (Edinburgh, 1988).

Stephen, Jeffrey, Scottish Presbyterians and the Act of Union 1707 (Edinburgh, 2007).

Stevenson, David, 'Blair, Robert (1593-1666)', Oxford DNB (Oxford University Press, 2004), http://www.oxforddnb.com/view/article/2569, accessed 1 Aug. 2015.

Stewart, David, Sketches of the Character, Manners, and Present State of the Highlanders of Scotland, 2 vols. (Edinburgh, 1822).

Stewart, M. A., 'The Early British Reception of Hume's Writings', in Peter Jones (ed.), The Reception of David Hume In Europe (London, 2005).

- 'Religion and Rational Theology', in Alexander Broadie (ed.), The Cambridge Companion to the Scottish Enlightenment (Cambridge, 2003).

Strauss, Gerald, 'The Dilemma of Popular History', Past \& Present, cxxxii (1991), $130-49$.

— , 'The Dilemma of Popular History: Reply', Past \& Present, cxli (1993), 215-19.

Strong, Roy, Tudor and Jacobean Portraits, 2 vols. (London, 1969).

Sugg, Richard, Mummies, Cannibals, and Vampires: The History of Corpse Medicine from the Renaissance to the Victorians (Abingdon, 2011).

Sutherland, Alex, The Brahan Seer: The Making of a Legend (Bern, 2009).

Suzuki, Akihito, 'Dualism and the Transformation of Psychiatric Language in the Seventeenth and Eighteenth Centuries', History of Science: An Annual 
Review of Literature, Research and Teaching, xxxiii (1995), 417-47.

Sveinsson, Einar Ólafur, The Folk-Stories of Iceland (London, 2003).

Tait, James, Two Centuries of Border Church Life, 2 vols. (Kelso, 1889-91).

Tarlow, Sarah, Ritual, Belief and the Dead in Early Modern Britain and Ireland (Cambridge, 2011).

Thomas, Keith, Religion and the Decline of Magic: Studies in Popular Beliefs in Sixteenth and Seventeenth Century England (London, 1971).

Thompson, E. P., 'History from Below', The Times Literary Supplement, mmmccexlv (1996), 279.

Thomson, Derick S., The Gaelic Sources of Macpherson's Ossian (Edinburgh, 1952).

—, An Introduction to Gaelic Poetry, 2nd edn (Edinburgh, 1989).

—, 'Macpherson, James (1736-1796)', Oxford DNB (Oxford University Press, 2004), http://www.oxforddnb.com/view/article/17728, accessed 1 Aug. 2015.

Throness, Laurie, A Protestant Purgatory: Theological Origins of the Penitentiary Act, 1779 (Aldershot, 2008).

Todd, Janet, Sensibility: An Introduction (London, 1986).

Todd, Margo, The Culture of Protestantism in Early Modern Scotland (New Haven, 2002).

Tongue, R. L., 'Folk-Song and Folklore', Folklore, lxxviii (1967), 293-303.

Trevor-Roper, Hugh, The Invention of Scotland: Myth and History (New Haven, 2008).

Trumpener, Katie, Bardic Nationalism: The Romantic Novel and the British Empire (Princeton, 1997). 
Tulloch, Graham, 'Hogg and the Novel', in Ian Duncan (ed.), The Edinburgh Companion to James Hogg (Edinburgh, 2012).

Tyson, R. E., 'Population Patterns to 1770', in Michael Lynch (ed.), Oxford Companion to Scottish History, electronic edn (University of Oxford, 2007), http://www.oxfordreference.com/view/10.1093/acref/9780199234820.001.00 01/acref-9780199234820-e-238?rskey=5tA1US\&result=1\#acref9780199234820-eSub-0180, accessed 1 Aug. 2015.

Valletta, Frederick, Witchcraft, Magic and Superstition in England, 1640-1670 (Aldershot, 2004).

VanderMolen, Ronald J., 'Providence as Mystery, Providence as Revelation: Puritan and Anglican Modifications of John Calvin's Doctrine of Providence', Church History, xlvii (1978), 27-47.

Vidal, Fernando, 'Ghosts of the European Enlightenment', in Mu-chou Poo (ed.), Rethinking Ghosts in World Religions (Leiden, 2009).

Voges, Friedhelm, 'Moderate and Evangelical Thinking in the Later Eighteenth Century: Differences and Shared Attitudes', Records of the Scottish Church History Society, xxii (1985), 141-57.

Walker, D. P., 'The Cessation of Miracles', in Ingrid Merkel and Allen. G. Debus (eds.), Hermeticism and the Renaissance: Intellectual History and the Occult in Early Modern Europe (Washington, 1988).

Walsham, Alexandra, 'Invisible Helpers: Angelic Intervention in Post-Reformation England', Past \& Present, ccviii (2010), 77-130.

—, 'Miracles in Post-Reformation England', in Kate Cooper and Jeremy Gregory (eds.), Signs, Wonders, Miracles: Representations of Divine Power in the Life of the Church (Woodbridge, 2005).

— 
_ 'The Reformation and "The Disenchantment of the World" Reassessed', Historical Journal, li (2008), 497-528.

Wasser, Michael, 'The Mechanical World-View and the Decline of Witch-Beliefs in Scotland', in Julian Goodare, Lauren Martin, and Joyce Miller (eds.), Witchcraft and Belief in Early Modern Scotland (Basingstoke, 2008).

Watt, James, Contesting the Gothic: Fiction, Genre and Cultural Conflict, 17641832 (Cambridge, 1999).

Weber, Max, The Protestant Ethic and the Spirit of Capitalism, trans. Talcott Parsons, electronic edn (Routledge, 2005), http://www.tandfebooks.com/ action/showBook?doi=10.4324/9780203995808, accessed 1 Aug. 2015.

—, 'Science as a Vocation', in H. H. Gerth and C. Wright Mills (eds.), From Max Weber: Essays in Sociology (New York, 1946).

Wells, Stanley, 'Staging Shakespeare's Ghosts', in Murray Biggs (ed.), The Arts of Performance in Elizabethan and Early Stuart Drama (Edinburgh, 1991).

Wells, Vaughan T., 'Law, Robert (d. c.1686)', Oxford DNB (Oxford University Press, 2004), http://www.oxforddnb.com/view/article/16152, accessed 1 Aug. 2015.

Westwood, Jennifer, and Sophia Kingshill, The Lore of Scotland: A Guide to Scottish Legends (London, 2009).

Whaley, Joachim (ed.), Mirrors of Mortality: Studies in the Social History of Death (Abingdon, 2011).

Whatley, Christopher A., The Industrial Revolution in Scotland (Cambridge, 1997).

Wheatley, Kim, 'The Blackwood's Attacks on Leigh Hunt', Nineteenth-Century Literature, xlvii (1992), 1-31.

White, Allan, 'Gordon, George, Fourth Earl of Huntly (1513-1562)', Oxford DNB (Oxford University Press, 2004), http://www.oxforddnb.com/view/article/ 
11034, accessed 1 Aug. 2015.

Wigelsworth, Jeffrey R., Deism in Enlightenment England: Theology, Politics, and Newtonian Public Science (Manchester, 2009).

Wilby, Emma, Cunning Folk and Familiar Spirits: Shamanistic Visionary Traditions in Early Modern British Witchcraft and Magic (Brighton, 2005).

Wilson, William, Folk Lore and Genealogies of Uppermost Nithsdale (Dumfries, 1904).

Wimberly, Lowry Charles, Folklore in the English and Scottish Ballads (Chicago, 1928).

Withers, Charles W. J., Geography, Science and National Identity: Scotland Since 1520 (Cambridge, 2001).

Wolterstorff, Nicholas, 'Locke's Philosophy of Religion', in Vere Chappell (ed.), Cambridge Companion to Locke (Cambridge, 1994).

Womack, Peter, Improvement and Romance: Constructing the Myth of the Highlands (Basingstoke, 1988).

Wood, J. Maxwell, Witchcraft and Superstitious Record in Southwest Scotland (Dumfries, 1911).

Wootton, David, 'New Histories of Atheism', in Michael Hunter and David Wootton (eds.), Atheism from the Reformation to the Enlightenment (Oxford, 1992).

Wormald, Jenny, Court, Kirk, and Community: Scotland, 1470-1625 (Edinburgh, 1991).

Wright, John P., 'Materialism and the Life Soul in Eighteenth-Century Scottish Physiology', in Paul Wood (ed.), The Scottish Enlightenment: Essays in Reinterpretation (Rochester [Vt.], 2000).

'Metaphysics and Physiology: Mind, Body and the Animal Economy in 
18th-Century Scotland', in M. A. Stewart (ed.), Studies in the Philosophy of the Scottish Enlightenment (Oxford, 1990).

Wunderli, Richard, and Gerald Broce, 'The Final Moment before Death in Early Modern England', Sixteenth Century Journal, xx (1989), 259-75.

Yeoman, Louise, “"Away with the Fairies", in Lizanne Henderson (ed.), Fantastical Imaginations: The Supernatural in Scottish History and Culture (Edinburgh, 2009).

—, 'Wodrow, Robert (1679-1734)', Oxford DNB (Oxford University Press, 2004), http://www.oxforddnb.com/view/article/29819, accessed 1 Aug. 2015.

Young, Francis, English Catholics and the Supernatural, 1553-1829 (Farnham, 2013).

Zigarovich, Jolene (ed.), Sex and Death in Eighteenth-Century Literature (Abingdon, 2013).

Zipes, Jack, 'Introduction: The Golden Key to Folk and Fairy Tales: Unlocking Cultural Treasures', in Jack Zipes (ed.), The Golden Age of Folk and Fairy Tales: From the Brothers Grimm to Andrew Lang (Indianapolis, 2013). 